\section{WNES}

National Center for Education Statistics

U.S. Department of Education Institute of Education Sciences NCES 2003-161

\section{A Study of Higher} Education Instructional Expenditures: The Delaware Study of Instructional Costs and Productivity

Research and Development Report

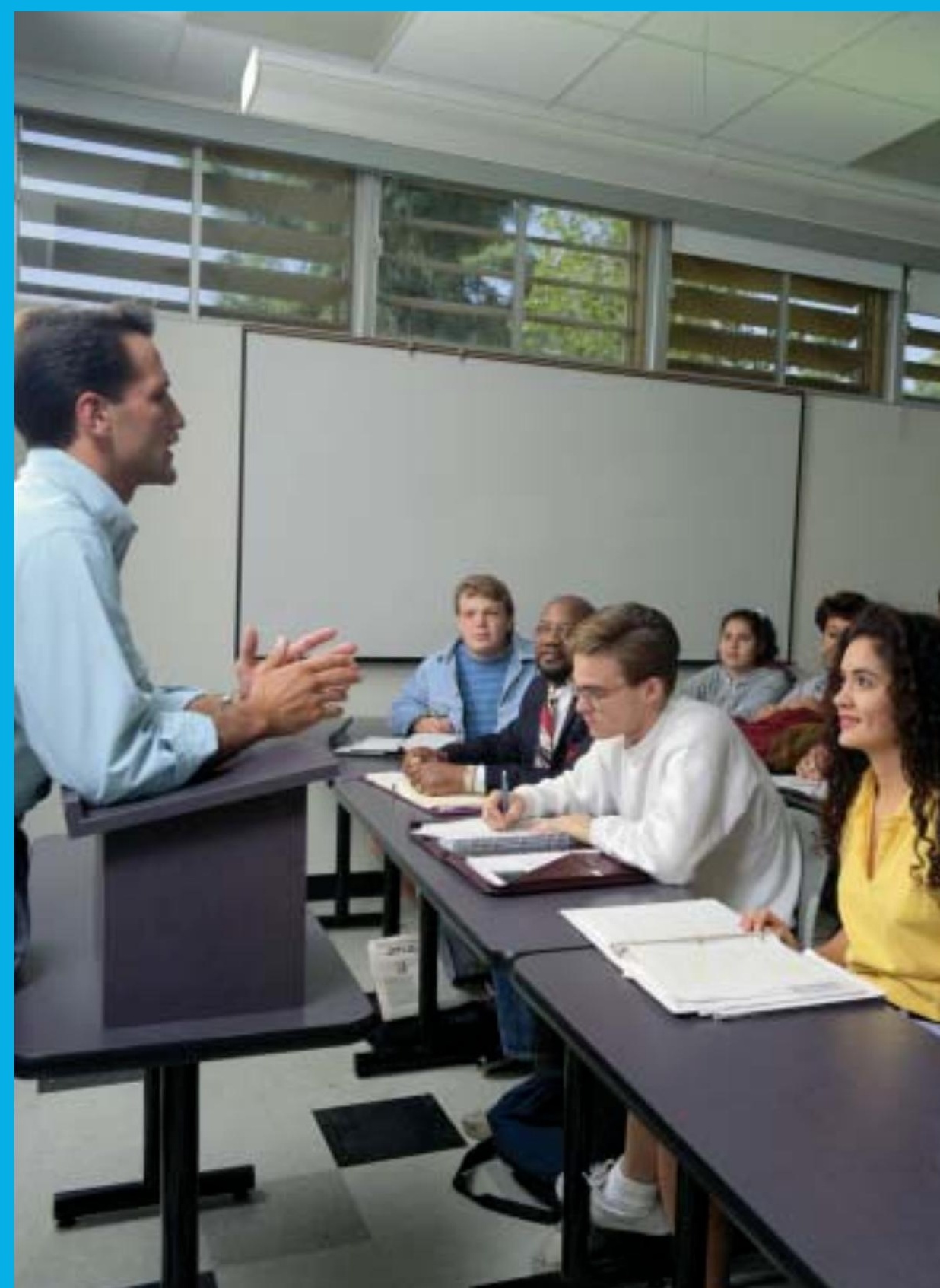


A Study of Higher

National Center for Education Statistics

U.S. Department of Education Institute of Education Sciences NCES 2003-161

\title{
Education Instructional Expenditures: \\ The Delaware Study of Instructional Costs and Productivity
}

Research and Development Report

\author{
Michael F. Middaugh \\ Assistant Vice President for Institutional Research and Planning \\ University of Delaware \\ Rosalinda Graham \\ Project Manager \\ Office of Institutional Research and Planning \\ University of Delaware \\ Abdus Shahid \\ Postdoctoral Research Associate \\ Office of Institutional Research and Planning \\ University of Delaware
}




\author{
U.S. Department of Education \\ Rod Paige \\ Secretary \\ Institute of Education Sciences \\ Grover J. Whitehurst \\ Director
}

\title{
National Center for Education Statistics
}

Val Plisko

Associate Commissioner

The National Center for Education Statistics (NCES) is the primary federal entity for collecting, analyzing, and reporting data related to education in the United States and other nations. It fulfills a congressional mandate to collect, collate, analyze, and report full and complete statistics on the condition of education in the United States; conduct and publish reports and specialized analyses of the meaning and significance of such statistics; assist state and local education agencies in improving their statistical systems; and review and report on education activities in foreign countries.

NCES activities are designed to address high priority education data needs; provide consistent, reliable, complete, and accurate indicators of education status and trends; and report timely, useful, and high quality data to the U.S. Department of Education, the Congress, the states, other education policymakers, practitioners, data users, and the general public.

We strive to make our products available in a variety of formats and in language that is appropriate to a variety of audiences. You, as our customer, are the best judge of our success in communicating information effectively. If you have any comments or suggestions about this or any other NCES product or report, we would like to hear from you. Please direct your comments to:

\author{
National Center for Education Statistics \\ Institute of Education Sciences \\ U.S. Department of Education \\ 1990 K Street NW \\ Washington, DC 20006
}

June 2003

The NCES World Wide Web Home Page is: http://nces.ed.gov

The NCES World Wide Web Electronic Catalog is: http://nces.ed.gov/pubsearch/index.asp

\section{Suggested Citation}

U.S. Department of Education, National Center for Education Statistics. A Study of Higher Education Instructional Expenditures: The Delaware Study of Instructional Costs and Productivity. NCES 2003-161, by Michael F. Middaugh, Rosalinda Graham, and Abdus Shahid. Project Officer: C. Dennis Carroll. Washington, DC: 2003.

\section{Contact:}

Aurora D'Amico

(202) 502-7334

Aurora.D'Amico@ed.gov 


\title{
Foreword
}

The Research and Development (R\&D) series of reports at NCES has been initiated:

1. To share studies and research that are developmental in nature. The results of such studies may be revised as the work continues and additional data become available.

2. To share the results of studies that are, to some extent, on the "cutting edge" of methodological developments. Emerging analytical approaches and new computer software development often permit new and sometimes controversial analyses to be done. By participating in "frontier research," we hope to contribute to the resolution of issues and improved analysis.

3. To participate in discussions of emerging issues of interest to educational researchers, statisticians, and the federal statistical community in general. Such reports may document workshops and symposia sponsored by NCES that address methodological and analytical issues or may share and discuss issues regarding NCES practices, procedures, and standards.

The common theme in all three goals is that these reports present results or discussions that do not reach definitive conclusions at this point in time, either because the data are tentative, the methodology is new and developing, or the topic is one on which there are divergent views. Therefore, the techniques and inferences made from the data are tentative and subject to revision. To facilitate the process of closure on the issues, we invite comment, criticism, and alternatives to what we have done. Such responses should be directed to:

\author{
Marilyn Seastrom \\ Chief Statistician \\ Statistical Standards Program \\ National Center for Education Statistics \\ 1990 K Street, NW \\ Washington, DC 20006-5654
}




\section{Acknowledgments}

Many individuals contributed in important ways to development of this report. The Delaware Study of Instructional Costs and Productivity is the data source for the analyses that comprise this study of higher education instructional expenditures. The Delaware Study would not exist were it not for the strong institutional commitment and support received from University of Delaware President David Roselle, Provost Daniel Rich, and most especially Executive Vice President David Hollowell. Larry Hotchkiss and David Kaplan, from the University of Delaware, provided critical advice and support with respect to the selection and use of statistical tests used in the analyses in this report.

Early drafts of the report benefited from extensive review and suggestions from Dennis Carroll, Associate Commissioner for Postsecondary Education, and Paula Knepper, both at the National Center for Education Statistics (NCES), and from Michael Lance, consultant with NCES. Several other individuals in Washington provided valuable feedback. They include Marilyn McMillen Seastrom, Chief Statistician for NCES; Grover J. Whitehurst, Director of the Institute of Education Sciences, U.S. Department of Education; Bernie Greene, Early Childhood, International and Crosscutting Studies Division, NCES; Ilona Berkovits, Division of Elementary, Secondary, and Longitudinal Studies, NCES; David Bergeron, Office of Postsecondary Education, U.S. Department of Education; Dan Goldenberg, Office of the Under Secretary, U.S. Department of Education; and Carol Fuller, National Association of Independent Colleges and Universities.

Finally, special thanks to the staff in the Office of Institutional Research and Planning at the University of Delaware, whose conscientious work on university institutional research projects allowed us time to pursue this project. Those individuals include Dale Trusheim, Associate Director; Karen Bauer, Assistant Director; Heather Isaacs, Institutional Research Analyst; Karen DeMonte, Institutional Research Analyst; and Maggie Brumit, Records Analyst/Coordinator. 


\section{EXECUTIVE SUMMARY}

A Study of Higher Education Instructional Expenditures is an examination of higher education costs undertaken by the National Center for Education Statistics (NCES). This study of higher education costs was mandated by Congress in the 1998 Higher Education Act. The NCES response to the congressional mandate encompassed three reports: the first, Study of College Costs and Prices, 1988-89 to 1997-98; followed by What Students Pay for College: Changes in Net Price of College Attendance Between 1992-93 and 1999-2000; and culminating in this third and final report.

The first report in the congressionally mandated study drew the distinction between sticker price, i.e., the tuition that an institution charges for a college education, and cost, i.e., the fiscal resources expended by the institution to provide that education. Additionally, researchers for the first part of the study found that certain factors are associated with tuition rates. Most notable at state-supported institutions is importance of annual budget appropriations. At private not-forprofit institutions, internal budget constraints, size of endowments, and external market competition were among factors associated with sticker price. There was little evidence indicating that expenditures for instruction were a major factor in determining tuition rates.

This report focuses solely on the issue of direct instructional expenditures, and the factors associated with the comparative magnitude of those expenditures at 4-year colleges and universities in the United States. As evident in the findings and conclusions, the factors associated with instructional expenditures are different from those associated with sticker price, as identified in the first part of the congressionally mandated study. Cost and price are not interchangeable constructs, and a strong statistical relationship between them has not been found.
The data source for this analysis is multiple cycles of the Delaware Study of Instructional Costs and Productivity, henceforth called the Delaware Study. Begun in 1992 by the Office of Institutional Research and Planning at the University of Delaware, the study has grown into a national data-sharing consortium embracing over 300 4-year colleges and universities across the United States. The foci of data-sharing activities are detailed analyses of teaching loads by faculty category, instructional costs, and externally funded scholarly activity, all at the level of the academic discipline.

\section{Goals and Limitations of This Study}

The primary objective of this analysis of instructional expenditures is the identification of those factors that contribute to describing direct instructional costs in the colleges and universities that participate in the Delaware Study.

The study is characterized by the following factors:

- Participation in the Delaware Study is voluntary, and is restricted to 4-year Title IVeligible institutions only. The fact that the data population used in this study is selfselected raises the issue of nonresponse bias. For example, institutions that participate in the Delaware Study typically have enrollments of at least 5,000 students and are organizationally complex, with discrete academic departments or programs that correspond with the fourdigit codes assigned to disciplines within the NCES Classification of Instructional Programs (CIP) taxonomy. In contrast, single purpose institutions with smaller enrollments frequently have multiple disciplines grouped within a given organizational structure, e.g., 
Division of Social Sciences, or Department of Education, etc., and participate in much smaller numbers than their larger, more complex counterparts. In addition, because participation is restricted to 4-year institutions, findings cannot be extended to the 2-year college sector.

- Because the population for this study is selfselected, it is, by definition, not a random sample. Descriptive statistics are applied to data from responding institutions to describe instructional expenditures for those institutions, but the findings cannot be inferentially generalized to the larger population of all Title IV-eligible 4-year colleges and universities in the United States. However, this study's findings nonetheless yield valuable descriptive information about expenditures in those institutions that participate in the Delaware data-sharing process.

- The Delaware Study expenditure data reflect direct instructional expense, and therefore cannot be used for a full cost model. There are methodological pitfalls and inconsistencies in full cost modeling in higher education, especially with respect to allocating indirect costs (as described in the full report).

Within the context of these characteristics, this study yields information about factors that contribute to direct instructional costs at an institution, and these expenditures generally compose the largest portion of the operating budget at most colleges and universities.

\section{Study Design and Methodology}

This study utilized data from multiple data collection cycles of the Delaware Study, focusing primarily on data collected during 1998, 2000, and 2001. Data were collected using an established survey instrument that requests detailed information on fall semester teaching loads by faculty category, and academic and fiscal year student credit hour production and direct expenses for instruction, research, and service activity.

Direct instructional cost per student credit hour taught is the focal dependent variable examined in this study. Patterns of dispersion and difference in cost across disciplines are examined through a series of analytical lenses that are typically assumed to be major cost factors in the literature. These include institutional mission as characterized by the Carnegie institutional classification. The Delaware Study employs the 1995 Carnegie taxonomy ${ }^{1}$ - research, doctoral, comprehensive, and baccalaureate institutions. The study also examines the impact of other variables such as highest degree offered within a discipline, and the relative emphasis on undergraduate versus graduate instruction within a discipline.

Using appropriate statistical tools, the relationship of cost to variables such as department size (measured in terms of number of faculty), proportion of faculty who are tenured, volume of student credit hours taught, and personnel expense as a percentage of total instructional costs is examined and measured. Effects of highest degree offered in the discipline, as well as Carnegie institutional classification, are also examined. Cost factors are determined by disciplines, or where more appropriate, groups of disciplines.

\section{Findings}

The key finding from analysis of multiple years of Delaware Study data is that most of the variance in instructional cost across institutions, as measured by direct expense per student credit hour taught, is associated with the disciplinary mix within an institution.

A secondary factor affecting cost is institutional mission, as related to Carnegie institutional classification. This result may be associated with different faculty responsibilities at institutions with different Carnegie classifications. For example, faculty at research universities,

\footnotetext{
${ }^{1}$ The 1995 Carnegie Taxonomy is fully described in appendix C.
} 
extensively engaged in research activity, might be expected to teach fewer student credit hours at higher costs than faculty at comprehensive institutions. However, Carnegie classification accounts for less of the cost differential between institutions than the disciplinary mix factor.

Figure A reflects actual academic year 2001 Delaware Study benchmarks ${ }^{2}$ for 5 of the 24 disciplines analyzed in this study. The benchmarks are mean values for direct expense per student credit hour taught, as reported by participating institutions. They have been refined to correct for outliers and influential cases, and as such, are fair reflections of the average cost of instruction in those disciplines.
In chemistry, average direct expense per student credit hour taught ranged from $\$ 181$ at comprehensive institutions to $\$ 264$ at research universities, an $\$ 83$ spread. The range in English is $\$ 28$, from a low of $\$ 112$ at comprehensive institutions to a high of $\$ 140$ at research universities. Foreign languages range from $\$ 131$ at doctoral universities to $\$ 202$ at baccalaureate colleges, a $\$ 71$ spread, while mechanical engineering ranges from $\$ 316$ at doctoral universities to $\$ 379$ at research universities, a difference of $\$ 63$. And sociology ranges from $\$ 100$ at comprehensive institutions to $\$ 138$ at baccalaureate colleges, a spread of $\$ 38$. These examples in figure A are typical of the ranges in any given Delaware Study data collection cycle.

Figure A. Direct expense per student credit hour taught: Institution type within discipline, 2001

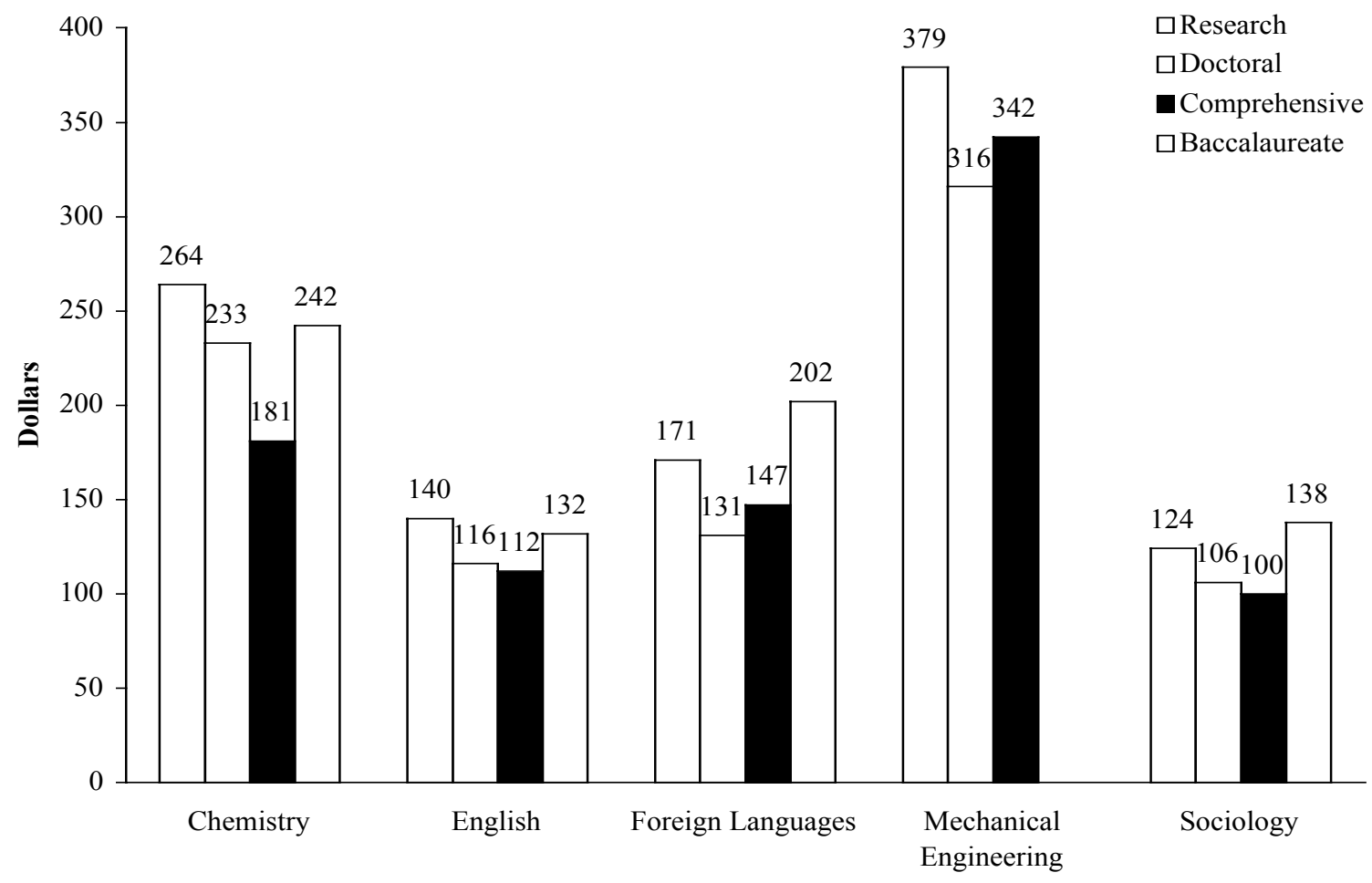

NOTE: Data for mechanical engineering at baccalaureate institutions are not applicable. SOURCE: University of Delaware, The Delaware Study of Instructional Costs and Productivity, 1998-2001.

\footnotetext{
${ }^{2}$ The complete set of Delaware Study benchmarks for all of the disciplines analyzed in this study is found in appendix tables D-1 through D-10.
} 
While the foregoing discussion demonstrates that there is variation within a discipline across institution types, figure B clearly illustrates there is also considerable variation across the disciplines within an institution. Using the same disciplinary examples, at a research university, the difference in direct expense per student credit hour taught between English and mechanical engineering is $\$ 239$; the difference between sociology and chemistry is $\$ 140$. Comparable patterns are apparent within the other Carnegie categories as well.

These cost differentials within disciplines across institutional types and between disciplines within those types lead to an overarching question. In describing the cost of instruction at higher education institutions, which is the more important factor-the designation of the institution as research, doctoral, comprehensive, or baccalaureate, or the configuration of disciplines that compose the institution?
Hierarchical linear modeling (HLM) ${ }^{3}$ is a statistical tool that provides the capability to disaggregate total variance in cost by institution, and by discipline within the institution. HLM helps to explore and describe the dispersion of instructional costs across institutions, and to identify those factors that are associated with the dispersion. The hierarchical linear model constructed in this study demonstrates that most of the variance in cost is at the discipline level within an institution, ranging from 76.0 percent in the 1998 data collection cycle to 82.6 percent in the 2000 cycle.

It can be asserted that Carnegie institutional classification, as a proxy for institutional mission, is tied to at least some of the dispersion of costs at the aggregate institutional level. When Carnegie classification is taken into account in the hierarchical linear model, the dispersion in cost across institutions decreases, and the relative

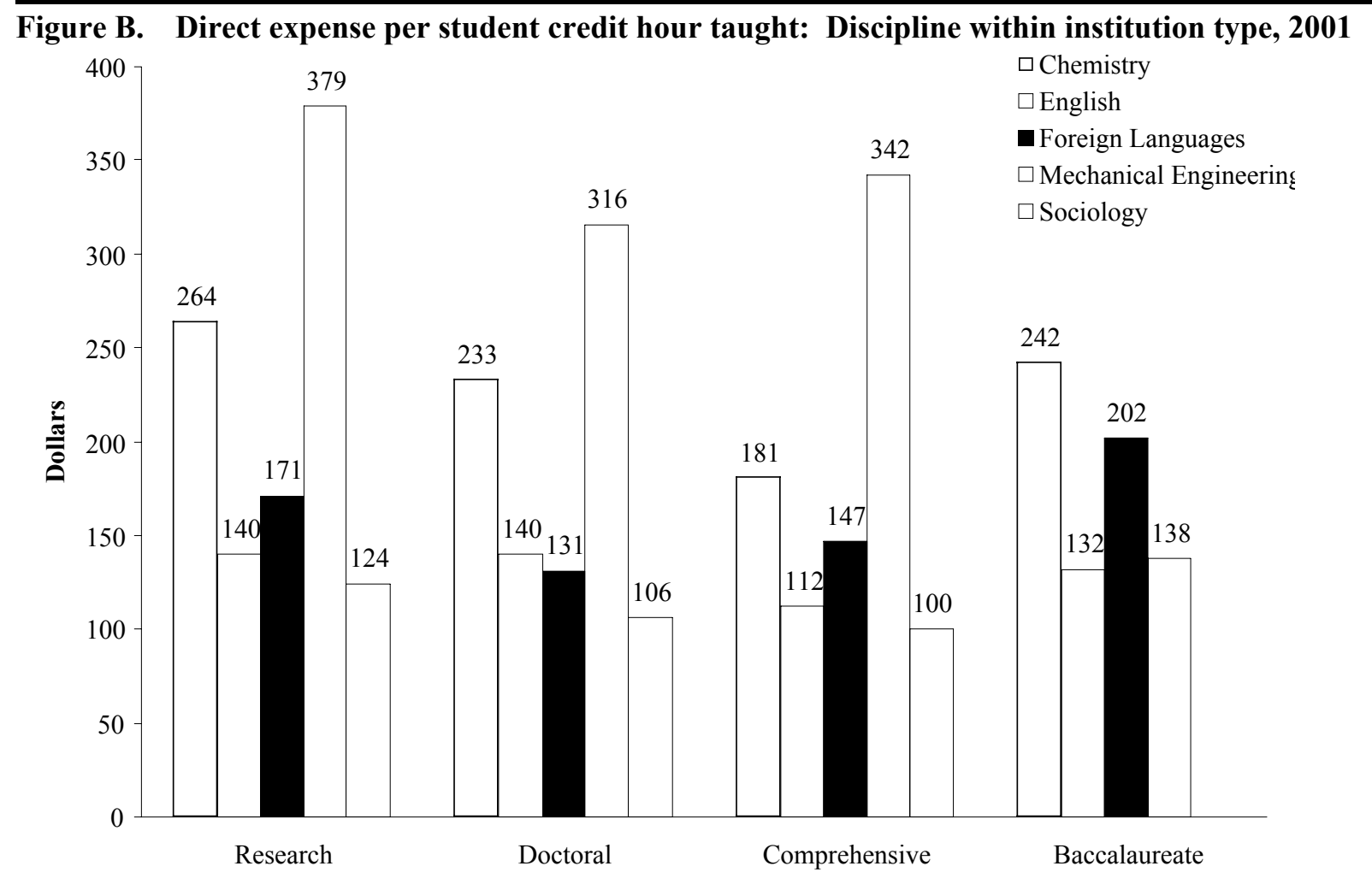

NOTE: Data for mechanical engineering at baccalaureate institutions are not applicable.

SOURCE: University of Delaware. The Delaware Study of Instructional Costs and Productivity, 1998-2001.

${ }^{3}$ A complete brief discussion of the statistical techniques used in analyzing cost variance is found in the Technical Notes (appendix E). 
variance due to disciplines within an institution ranges from 81.0 to 88.0 percent.

This important finding underscores that the disciplines that compose a college or university's curriculum, not its Carnegie designation, are associated with most of the dispersion of costs among institutions. This further highlights the distinction between costs, i.e., instructional expenditures, and price, i.e., tuition. Stated plainly, price is a constant for all undergraduates at an institution; chemistry and engineering majors pay the same tuition rate as English and sociology majors. However, the cost of delivering instruction in those disciplines varies widely.

Finding that most of the variation in instructional expenditures is associated with the mix of disciplines within an institution is also important in light of the issues raised in the first part of the congressionally mandated study. Researchers found no apparent relationship between the level of instructional expenditures at an institution and the tuition rate charged by that institution. Results of this analysis of direct instructional expense underscore the difficulty in relating price to cost at the level of the academic discipline. While direct instructional expense per student credit hour taught in civil engineering is three times higher than that for sociology, it is not practical for an institution to charge engineering majors a tuition rate three times that charged to sociology majors.

Indeed, the first report in the cost study found that institutional tuition rates at public institutions are determined largely by state appropriation levels, while competitive market forces shape tuition at private institutions. Neither of these external factors has anything to do with what it costs to deliver instruction in a discipline. Price (i.e., tuition) and cost (i.e., institution expenditures) are not interchangeable constructs.

While the foregoing discussion described the forces that are associated with instructional cost within an institution, the study also focused on those factors that impact expenditures within a discipline. In The Economics of American
Universities, ${ }^{4}$ Paul Brinkman postulated that the behavior of marginal and average costs can be associated with four dimensions: size (i.e., quantity of activity or output), scope of services offered, level of instruction (for instructional costs), and discipline (for instructional costs).

The analyses in this study determined that 60 to 75 percent of the variation in cost within a discipline or groups of disciplines is associated with specific cost factors consistent with those identified by Brinkman. While the association of a given variable with cost, as measured by direct expense per student credit hour taught, may vary from discipline to discipline, the following general patterns are consistently observed:

- The volume of teaching activity, as measured by total student credit hours taught, is a major cost factor. Cost decreases as volume increases.

- Department size, as measured in terms of total number of faculty, is a consistent cost indicator. The larger the department, the higher the cost.

- The proportion of faculty holding tenure is a cost factor. The higher the proportion of tenured faculty, the higher the cost.

- The presence of graduate instruction in a discipline increases costs, although the measured effect of this variable on direct expense in this study is smaller than teaching volume, department size, and faculty tenure rate.

- Similarly, the extent to which expense is associated with personnel costs, as opposed to equipment costs, has less impact on total direct instructional expenditures within a discipline than do teaching volume, department size, and tenure rate.

\footnotetext{
${ }^{4}$ P.T. Brinkman, Higher Education Cost Functions, in S.A Hoenack and E.L. Collins, Eds., The Economics of American Universities: Management, Operations and Fiscal Environment. (Albany, NY: State University of New York Press, 1990).
} 


\section{Conclusions}

While the first report in the congressionally mandated study of expenditures in higher education provided evidence that the price that students pay for an education is largely associated with factors external to the institution, the analyses in this report suggest that the direct cost of providing that education is more closely associated with internal institutional decisions and priorities.

The mix of disciplines that compose an institution's overall curriculum is associated with direct instructional expense at that institution and, to a smaller extent, its designation as a research, doctoral, comprehensive, or baccalaureate institution. Costs vary more substantially across disciplines within a given institution than they do across institutions within a given discipline.

Within the individual disciplines at an institution, economies of scale have the greatest impact on instructional costs. When given a faculty of fixed size, the more student credit hours taught, the lower the unit cost. Increasing the size of that faculty without a concomitant increase in student credit hour production raises instructional expense. Increasing the proportion of tenured faculty-that cadre of faculty that is better compensated and are essentially a "fixed cost"-will increase instructional expense. And to a lesser extent, introducing or increasing the level of graduate instruction raises instructional costs.
While the data analyzed in this study reflect cost patterns for those 4-year colleges and universities participating in the Delaware Study of Instructional Costs and Productivity only, they nonetheless provide a clear and measurable understanding of cost behaviors within those institutions. These are fresh data, collected at the academic discipline level of analysis, and lend themselves to descriptive statistics that illuminate and clarify cost patterns within those institutions that elect to belong to this data-sharing consortium.

A college or university's tuition rate is tied to what competing institutions charge, i.e., marketplace conditions, and what state legislatures provide as an operating subsidy. Instructional expenditures are tied to more fixed-cost factors, i.e., the mix of disciplines in place at the institution, and within those disciplines, student credit hour production, department size, and tenure rate. This study suggests that depending upon their magnitude, these variables constitute a baseline level for instructional costs within a discipline, and these costs vary less by discipline across institutions than they do among disciplines within an institution.

Most higher education institutions have multiple revenue streams, tuition being but one, to cover instructional costs. It is evident from this study that the factors that are associated with instructional costs are very different from the factors that are associated with tuition prices. 


\section{Table of Contents}

\section{$\begin{array}{ll}\text { Chapter } & \text { Page }\end{array}$}

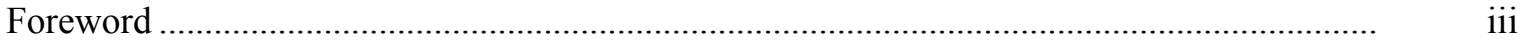

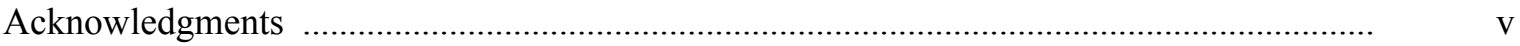

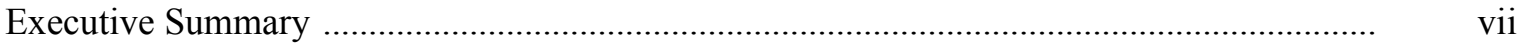

List of Text Tables ..........................................................................................................

List of Appendix Tables ...................................................................................................

List of Figures ............................................................................................................

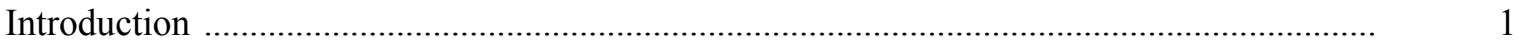

NCES Response to the Congressional Mandate .............................................................. 1

The Delaware Study of Instructional Costs and Productivity ...........................................

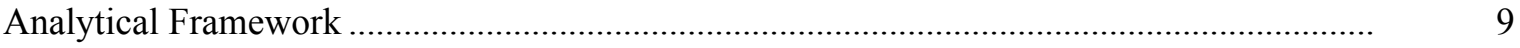

Data Source: The Delaware Study of Instructional Costs and Productivity ......................

Bias Issues in the Data.................................................................................................

Analysis of Nonresponse Bias...................................................................................

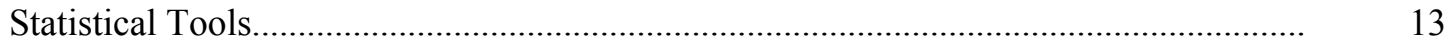

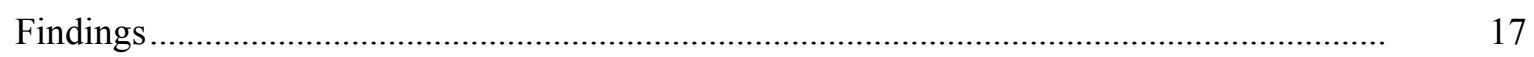

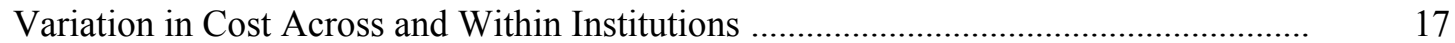

Differences in Costs Between and Across Disciplines ................................................... 19

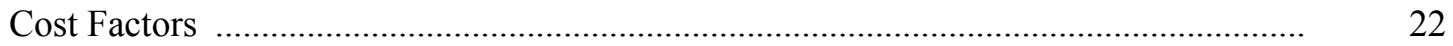

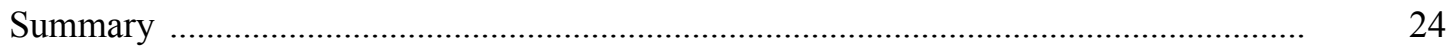

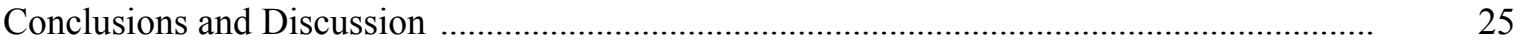

Conclusions

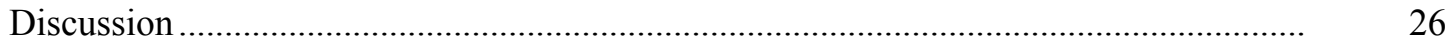

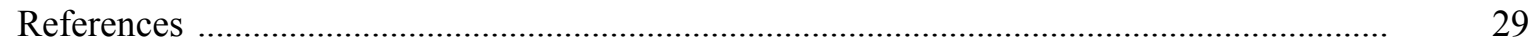




\section{Table of Contents-Continued}

\section{List of Appendices}

\section{$\begin{array}{lll}\text { Appendix } & \text { Page }\end{array}$}

A Delaware Study Institutional Participant List .............................................................. A-1

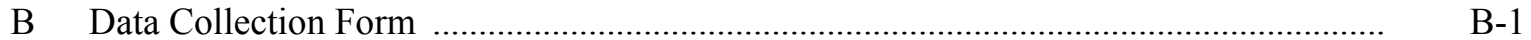

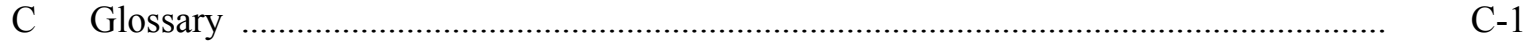

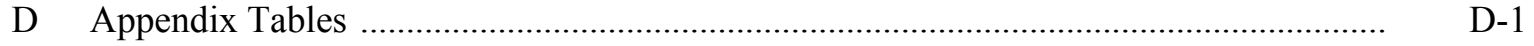

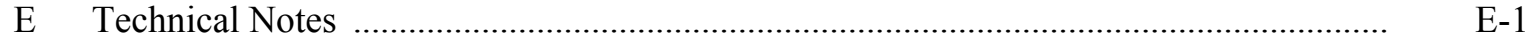

\section{List of Text Tables}

\section{Text Table}

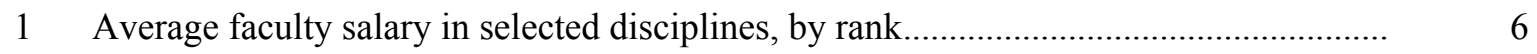

2 Number of institutions participating in the Delaware Study, by Carnegie institutional classification, by year: 1997-2001

3 Direct instructional expense per student credit hour taught in selected academic disciplines, by Carnegie institution type: 1998, 2000, and 2001

4 Direct instructional expense per student credit hour taught in selected academic disciplines, by Carnegie institution type, by quartile: 2001

5 Study of variance components of cost per student credit hour based on hierarchical linear modeling: 1998, 2000, and 2001

\section{List of Appendix Tables}

\section{Appendix Table}

D-1 Nonresponse bias for 2001 Delaware Study, by institution's Carnegie classification

D-2 Nonresponse bias for 2000 Delaware Study, by institution's Carnegie classification

D-3 Nonresponse bias for 1999 Delaware Study, by institution's Carnegie classification 


\section{Table of Contents-Continued}

\section{List of Appendix Tables-Continued}

\section{Appendix Table}

D-4 Nonresponse bias for 1998 Delaware Study, by institution's Carnegie classification

D-5 Nonresponse bias for 1997 Delaware Study, by institution's Carnegie classification

D-12

D-6 Summary of ANOVA to test for differences in average cost of instruction, by discipline and Carnegie classification, by highest degree offered, and undergraduate/graduate program mix in discipline: 2001, 2000, and 1998 Delaware Study

D-7 Pairwise multiple comparison of cost of instruction by discipline within Carnegie classification based on the Bonferroni procedure at the 5 percent level of significance: 2001 Delaware Study

D-8 Pairwise multiple comparison of cost of instruction by discipline within Carnegie classification based on the Bonferroni procedure at the 5 percent level of significance: 2000 Delaware Study

D-9 Pairwise multiple comparison of cost of instruction by discipline within Carnegie classification based on the Bonferroni procedure at the 5 percent level of significance: 1998 Delaware Study

D-10 Pairwise multiple comparison of cost of instruction by discipline within highest degree offered based on the Bonferroni procedure at the 5 percent level of significance: 2001 Delaware Study

D-11 Pairwise multiple comparison of cost of instruction by discipline within highest degree offered based on the Bonferroni procedure at the 5 percent level of significance: 2000 Delaware Study

D-12 Pairwise multiple comparison of cost of instruction by discipline within highest degree offered based on the Bonferroni procedure at the 5 percent level of significance: 1998 Delaware Study

D-13 Pairwise multiple comparison of cost of instruction by discipline within undergraduate/graduate program mix based on the Bonferroni procedure at the 5 percent level of significance: 2001 Delaware Study 


\section{Table of Contents-Continued}

\section{List of Appendix Tables-Continued}

\section{Appendix Table}

D-14 Pairwise multiple comparison of cost of instruction by discipline within undergraduate/graduate program mix based on the Bonferroni procedure at the 5 percent level of significance: 2000 Delaware Study

D-15 Pairwise multiple comparison of cost of instruction by discipline within undergraduate/graduate program mix based on the Bonferroni procedure at the 5 percent level of significance: 1998 Delaware Study

D-16 Summary of determinants of direct instructional cost per student credit hour taught, by discipline: 2001 Delaware Study

D-17 Summary of determinants of direct instructional cost per student credit hour taught, by discipline: 2000 Delaware Study

D-18 Summary of determinants of direct instructional cost per student credit hour taught, by discipline: 1998 Delaware Study

\section{List of Figures}

Figure

A Direct expense per student credit hour taught: Institution type within discipline, 2001

B Direct expense per student credit hour taught: Discipline within institution type, 2001

$1 \quad$ Winston full cost model: Annotated formula for cost per student 
As a part of the Higher Education Amendments of 1998, Congress required that the National Center for Education Statistics (NCES) conduct a study of expenditures in higher education. This legislation specifically required that the study include information concerning:

- The change in tuition and fees compared with the Consumer Price Index and other appropriate measures of inflation;

- Faculty salaries and benefits;

- Administrative salaries, benefits, and expenses;

- Academic support services;

- Research;

- Operations and maintenance; and

- Institutional expenditures for construction and technology, and the potential cost of replacing instructional buildings and equipment.

The study was also to include an evaluation of expenditure patterns over time, an evaluation of the relationship of expenditures to the price charged for a college education, and the impact of tuition discounting and federal financial aid on tuition-setting policy.

\section{NCES Response to the Congressional Mandate}

NCES elected to respond to the congressional mandate for a study of higher education costs through a statistical analysis of factors that drive tuition at higher education institutions, supplemented by a series of commissioned expert papers. Both the analysis and the papers defined the conceptual framework for cost analysis, and responded to several of the key congressional concerns with respect to the relationship between the price charged to students for a college education and the cost of that education.

The commissioned papers included the following:

- Cost Analysis and the Formulation of Public Policy, Dennis P. Jones, National Center for Higher Education Management Systems

- Institutional Financial Health: Tuition Discounting and Enrollment Management, Lucie Lapovsky, Mercy College (New York)

- Higher Education's Costs, Prices, and Subsidies: Some Economic Facts and Fundamentals, Gordon C. Winston, Williams College (Massachusetts)

- Issues of Cost and Price in Higher Education: Observations on Needed Data and Research, Michael McPherson, Macalester College (Minnesota), and Morton Owen Schapiro, Williams College

- Higher Education and Those "Out of Control Costs," D. Bruce Johnstone, University of Buffalo (New York)

- An Essay on College Costs, David W. Breneman, University of Virginia

- Measuring Higher Education Costs: Considerations and Cautions, Michael F. Middaugh, University of Delaware

Despite the disparate backgrounds and institutions of the authors, certain consistent themes run through the expert papers that speak specifically to questions raised by Congress with respect to the relationship between the cost and price of a college education. 
1. There is not a pure cause-and-effect relationship between price and cost. While tuition revenues are associated with expenditure patterns at an institution, they are also associated with revenue streams available to that institution. Tuition rates at public institutions are clearly associated with the level of state appropriations. On the other hand, tuition rates at private institutions are associated with competitive market place as much as with expenditures.

2. While tuition discounting is an issue at colleges and universities, especially private institutions, tuition rates are to a greater extent tied to what neighboring institutions, particularly public institutions, are charging.

3 .Expenditure/cost patterns represent institutional choices, values, and priorities. They reflect choices made within the constraints of available resources, i.e., revenue streams.

While Congress may have been looking for a simple relationship between the price of a higher education and the cost of delivering that education, these papers deliver compelling arguments for environmental factors that have little to do with expenditure rates as the major determinants of tuition levels. The study specifically cites declining state appropriations as the major factor associated with rising tuition rates at public institutions, while competitive market pressures and the availability of nontuition revenue streams are tied to tuition increases at private, not-forprofit institutions. That said, the issue raised by Congress as to how college and universities spend money, i.e., for what purpose and with what results, is deserving of a clear and credible response.

In attempting to formulate a response over the years, colleges and universities have developed full cost models that look at total expenditures at groups of institutions without regard to differences between and among those institutions with respect to mission and disciplinary mix - both of which have profound impacts on expenditure patterns. The dialogue is further confounded when, in attempting to distinguish between direct and indirect costs in higher education, the full cost model at one institution may use one battery of indirect cost formulas while the model at another uses an entirely different set of formulas. In each case, the formulas are dependent upon funding source and purpose of expenditure.

Full cost models of higher education expenditures attempt to describe direct expenditures-particularly those for instruction and student services-plus what are commonly referred to as indirect costs, i.e., expenditures associated with research and public service, overhead associated with administrative costs, and costs associated with the operation and maintenance of the physical plant. One of the oldest and most standard of full cost formulas was developed by Kent Halstead of Research Associates of Washington, and was used for years in their publication Higher Education Revenues and Expenditures. This annual volume computes, for each institution in the country, a "Full Instructional Cost per Full Time Equivalent Student," using data entirely derived from the Integrated Postsecondary Educational Data System (IPEDS) database. The formula for full instructional cost is as follows:

Full Instructional Cost equals the sum of direct costs for instruction and student services plus indirect costs equal to total institutional and academic support and institutional support expenditures and plant expenditures less overhead for funded research and public service estimated at 33.3 percent of the expenditures for these two activities.

The National Commission on the Cost of Higher Education (1998), charged with responsibility for determining the relationship between higher education expenditures and tuition or "sticker price," relied heavily on the work of Gordon Winston of Williams College and the Williams Project on the Economics of Higher Education. The Winston model is predicated on the assumption that some expenditures are clearly related to instruction, while some are only partially related, and to both of these must be added a proportion of capital costs (figure 1). 
Figure 1. Winston full cost model: Annotated formula for cost per student

Cost $=$

\begin{tabular}{|c|c|c|}
\hline $\begin{array}{c}\text { Clearly } \\
\text { instruction }\end{array}$ & $\begin{array}{c}\text { Proportion } \\
\text { partially } \\
\text { instruction }\end{array}$ & $\begin{array}{c}\text { Proportion } \\
\text { capital } \\
\text { costs }\end{array}$ \\
\hline \multirow[t]{2}{*}{$\begin{array}{l}\text { Current expenditures on: } \\
\text { Instruction } \\
\text { Student services }\end{array}$} & $\begin{array}{l}\text { Current expenditures on: } \\
\text { Academic support } \\
\text { Institutional support } \\
\text { Operation of physical plan }\end{array}$ & $\begin{array}{l}\text { Depreciation ( } 2.5 \%) \text { : } \\
\text { Replacement value of buildings } \\
\text { Replacement value of equipment } \\
\text { plus } \\
\text { Opportunity cost }(9.12 \%) \text { : } \\
\text { Replacement value of buildings } \\
\text { Replacement value of equipment } \\
\text { Replacement value of land }\end{array}$ \\
\hline & \multicolumn{2}{|c|}{$\begin{array}{l}\text { Current expenditures on instruction and student services } \\
\quad \text { divided by } \\
\text { Total current fund expenditures less: current expenditures on academic support, } \\
\text { institutional support, operation of physical plan, scholarships and fellowships, } \\
\text { mandatory and non-mandatory transfers }\end{array}$} \\
\hline
\end{tabular}

Cost per student $=$

Cost divided by full-time-equivalent enrollment

SOURCE: National Commission on the Cost of Higher Education. Straight Talk College Costs and Prices. Phoenix, AZ: Oryx Press, 1988.

The Halstead and Winston models illustrate the difficulty in developing full cost models for higher education. The allocation of indirect costs or administrative overhead to the instructional function is an issue of judgment. Why does Halstead assume that the cost of overhead for research and service activity is 33 percent? Why not 25 percent or 40 percent? Halstead uses total expenditures for academic and institutional support plus operation and maintenance of physical plant; Winston has developed a proportional allocation for these costs. The Halstead model excludes capital costs; Winston includes them. Is one model superior to the other? Brinkman (2000, pp. 11-12) put it best:

A problem in determining full costs is that the schemes used to allocate indirect costs are, if not arbitrary, at least imprecise. This remains stubbornly true even though the problem has been worked on for some time, including a national effort in the 1970's and early 1980's to develop appropriate procedures for full costing. Despite such efforts, making mistakes in allocating indirect costs is still easy. For example, it is a heroic assumption that library usage correlates well with student credit hour across all disciplines or that one square foot of space is necessarily worth as much as another. The analyst who does not accept these simplifying assumptions is left with having to actually measure the impact of a particular organization or activity on various support systems, a daunting and expensive task that might at some point still depend on arbitrary valuation of some facet of the production process.

The difficulty in accurately and systematically allocating indirect costs across disciplines and institution types is not a recent roadblock in developing full cost models. Jones (2000) pointed out that full cost analyses start with accounting data and rely on adjustments to, and allocations of 
these financial data to arrive at answers, making the analyses captives of the purposes, conventions and limitations of such data. Hoenack (1990) particularly focused on the need to develop reliable means for accurately tracking overhead associated with research and service activity as well as instruction.

The foregoing complexities in describing and allocating indirect costs have been further exacerbated by a schism within the accounting community between institutions governed by the Financial Accounting Standards Board (FASB), generally independent or privately chartered colleges and universities, and those governed by the Governmental Accounting Standards Board (GASB), generally public, state-assisted institutions. The differences in accounting standards between the two groups are so significant that IPEDS has been forced to develop separate Finance surveys for FASB and GASB institutions, and comparability of data is an issue.

In initially responding to Congress and others seeking an assessment of major cost factors in higher education, analytical vehicles should not be encumbered with descriptors that are arbitrary or imprecise. In developing the Delaware Study of Instructional Costs and Productivity, the data source used in this study, Middaugh (2001, pp. 73-74) stated:

It is important to underscore that for each of the expenditure categories [instruction, research, and service] only direct costs are measured. In creating a framework for productivity analysis, it is important that the data be credible and verifiable. The standard definitions are clear and precise for identifying direct expense by institutional functional category. Measuring indirect costs, that is, administrative costs, utilities costs, capital costs, and so on, is less uniform and precise. Indeed, on any given campus there are multiple calculations for indirect costs based upon the academic disciplines for which costs are being recovered. For the sake of clarity, simplicity, and credibility, the discussion of costs [in this analysis] will in no way attempt to measure full costs, only direct expenses.

Brinkman (2000) emphasizes that, "The cost accounting data developed for the Delaware Study of Instructional Costs and Productivity is a good example of data suitable for subsequent statistical, econometric type analyses."

\section{The Delaware Study of Instructional Costs and Productivity}

The evolution of the Delaware Study of Instructional Costs and Productivity ${ }^{4}$ is thoroughly detailed in the book, Understanding Faculty Productivity: Standards and Benchmarks for Colleges and Universities (Middaugh, 2001), and in articles in Planning for Higher Education, the official journal of the Society for College and University Planning (Middaugh 1996, 1999). The following is a capsulization of the rationale that underpins the conceptual framework for the study, as well as a brief discussion of the methodology.

The Delaware Study is predicated on the operating principle that any meaningful analysis of costs and productivity in institutions of higher education must take place at the academic discipline level of analysis. Institutional aggregate data, while useful in making broad, general statements about higher education costs, may actually mask factors associated with expenditures and lead to erroneous conclusions when making policy related to instructional costs and productivity. For example, a commonly used measure of instructional costs is one derived by taking total direct expenditures for instruction, as reported on the IPEDS Finance survey, and dividing that total by the number of full-time-equivalent ( F T E) students at the institution. FTE students is a headcount measure derived by taking the part-time headcount

\footnotetext{
${ }^{4}$ The Delaware Study of Instructional Costs and Productivity is a data-sharing consortium of colleges and universities throughout the United States. Access to Delaware Study data is restricted to participating institutions. Questions concerning data access should be directed to the Office of Institutional Research and Planning at the University of Delaware, 325 Hullihen Hall, Newark DE 19716.
} 
enrollment at a college or university, dividing it by three, and adding the quotient to the full-time headcount enrollment (Taylor and Massy 1996.) While this measure of "Direct Instructional Expense per FTE Student" might quite appropriately be used to compare average instructional cost between and among research universities as a group, doctoral universities as a group, or comprehensive or baccalaureate institutions as a group, it should be used to compare individual institutions with caution and when much is known about the curricular offerings at the institutions being compared.

Specifically, only institutions with similar curricular mixes should be compared using institution-wide metrics such as Direct Instructional Expense per FTE Student. One might wish to compare two research/doctoral intensive universities, as defined under the 2000 Carnegie Institutional Classification convention. Suppose one of the institutions is heavily oriented toward the natural and physical sciences, with significant emphasis on graduate education; the other is steeped in the social sciences and humanities with lesser emphasis on graduate education. The former institution is weighted with disciplines that are typically characterized by small class instruction in equipment-intensive laboratories, while the latter more typically uses large classroom, lecture-based pedagogy in many of its classes. Any institution-wide comparison of costs without consideration of disciplines between these universities will be totally misleading.

To appreciate the impact of academic discipline on instructional cost, one need only consider faculty salaries. Table 1 contains the average faculty salary, by rank, for 24 disciplines typically found at most 4-year institutions in the United States. The data are taken from the annual survey of faculty salaries by discipline conducted by Oklahoma State University. While the data reflect average salaries for flagship university members of the National Association of State Universities and Land Grant Colleges, this resource is a frequently used benchmark for identifying marketplace salaries for hiring purposes.
While it is obvious that there is disparity between and across academic disciplines, even at the full professor rank, the important information in table 1 is at the assistant professor and new assistant professor rank. There are clear marketplace differentials between entry-level salaries for new faculty in quantitative disciplines such as mathematics, engineering, computer science, economics, and business, when compared with arts, humanities, and social sciences. The operating assumption in the Delaware Study is that instructional expenditures are largely associated with personnel costs, and that faculty salary differentials will constitute a significant cost factor across academic disciplines. This is consistent with the finding from the first part of the congressionally mandated study that instructional expenditures reflect institutional choices and priorities. Recruiting and retaining high-quality faculty in a very competitive marketplace requires competitive compensation, but the level of competition and compensation clearly varies from discipline to discipline. The differences among the disciplines is further exacerbated by the fact that programs in the sciences and engineering are more equipment-intensive than other disciplines, underscoring the need to examine instructional expenditures at an institution as a function of programmatic mix.

In order to better understand factors associated with instructional expenditures in higher education, the Office of Institutional Research and Planning at the University of Delaware was asked to analyze multiple data collection cycles from the Delaware Study. The Delaware Study is a datasharing consortium embracing 4-year colleges and universities running the full spectrum of the 1995 Carnegie Institutional Taxonomy, i.e., research, doctoral, comprehensive, and baccalaureate. ${ }^{5}$ The consortium shares detailed information on faculty teaching loads by instructor classification and direct expenditures for instruction, research, and public service activity. Data are collected and analyzed by academic discipline.

\footnotetext{
${ }^{5}$ The 1995 Carnegie Taxonomy is used throughout this report, as it is analytically more meaningful for this analysis than the current Carnegie taxonomy.
} 
Table 1. Average faculty salary in selected disciplines, ${ }^{1}$ by rank

\begin{tabular}{|c|c|c|c|c|}
\hline Discipline & $\begin{array}{r}\text { Full } \\
\text { professor }\end{array}$ & $\begin{array}{l}\text { Associate } \\
\text { professor }\end{array}$ & $\begin{array}{l}\text { Assistant } \\
\text { professor }\end{array}$ & $\begin{array}{r}\text { New assistant } \\
\text { professor }\end{array}$ \\
\hline 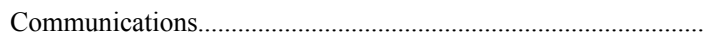 & $\$ 73,406$ & $\$ 54,126$ & $\$ 44,785$ & $\$ 43,458$ \\
\hline 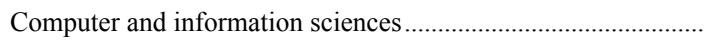 & 100,780 & 75,123 & 67,929 & 66,698 \\
\hline Education & 75,564 & 55,669 & 45,420 & 45,614 \\
\hline Engineering & 103,828 & 70,207 & 56,940 & 57,410 \\
\hline Foreign languages and literature & 67,335 & 50,005 & 41,240 & 40,763 \\
\hline 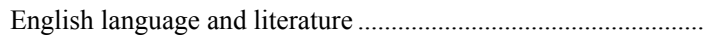 & 73,273 & 52,026 & 42,292 & 41,314 \\
\hline 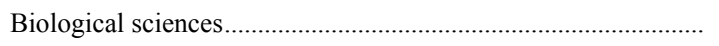 & 78,506 & 56,951 & 47,279 & 47,900 \\
\hline Mathematics & 80,990 & 57,421 & 47,959 & 45,101 \\
\hline Philosophy & 76,890 & 52,734 & 41,812 & 40,369 \\
\hline Chemistry & 89,245 & 58,527 & 49,292 & 46,726 \\
\hline Geology & 77,266 & 56,946 & 48,552 & 47,026 \\
\hline Physics ................................ & 85,998 & 60,365 & 53,123 & 50,953 \\
\hline 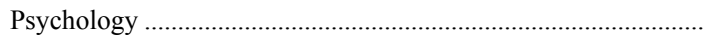 & 83,382 & 74,606 & 55,953 & 46,263 \\
\hline Anthropology ........................................ & 74,751 & 53,745 & 44,668 & 43,371 \\
\hline Economics & 99,447 & 67,945 & 60,565 & 62,635 \\
\hline 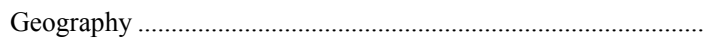 & 75,415 & 56,597 & 45,306 & 43,527 \\
\hline 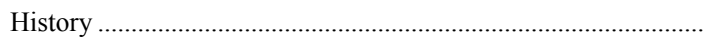 & 77,849 & 53,859 & 42,800 & 41,491 \\
\hline Political science & 82,480 & 56,306 & 45,960 & 45,025 \\
\hline Sociology & 78,900 & 54,793 & 45,753 & 45,294 \\
\hline 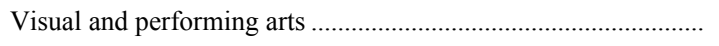 & 65,645 & 50,349 & 39,979 & 37,530 \\
\hline Nursing & 77,652 & 60,109 & 48,521 & 49,158 \\
\hline 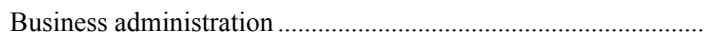 & 110,753 & 83,558 & 81,615 & 83,835 \\
\hline 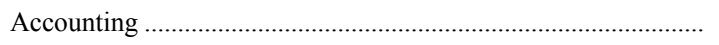 & 110,424 & 87,610 & 83,553 & 88,854 \\
\hline 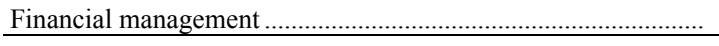 & 115,314 & 91,568 & 88,948 & 86,515 \\
\hline
\end{tabular}

Since its inception in 1992, nearly 350 colleges and universities have participated in the Delaware Study (see appendix A for the list of participants). A substantial portion of the participant pool submits data on an annual basis; other institutions elect to participate on an alternate-year or less regular interval cycle. It should be noted that this is a voluntary data-sharing consortium. Institutions elect to participate during any given data cycle, and the data sample for that cycle is therefore not random. The issue of a nonrandom sample and potential nonresponse bias will be addressed throughout this report.

The Delaware Study collects teaching load and financial data at the academic discipline level of analysis. The underlying assumption in this data collection strategy is that there are very real differences between and across disciplines with respect to magnitude of teaching loads and cost.
To ensure comparability of data, disciplines are defined using the NCES Classification of Instructional Programs (CIP) taxonomy. Data are typically collected at the four-digit CIP level, although a number of participating institutions request benchmarking at the six-digit CIP level, and where sufficient cases exist (i.e., $\mathrm{N}$ equal to or greater than 5), accommodation is made.

The Delaware Study Data Collection Form comprises two parts (see appendix B). Part A is a detailed collection of information on faculty teaching loads during the fall term of the academic year under analysis. Information is collected on student credit hours and organized class sections taught by each of four discrete categories of faculty. The faculty categories include tenured/tenure eligible; faculty on recurring contracts at the institution but who are in nontenurable lines; supplemental and adjunct faculty; 
and graduate teaching assistants. While student credit hour generation is a fairly obvious measure of teaching productivity, data on the number of class sections taught is also collected, as not all instructional activity is credit-bearing. It is not uncommon to find associated with the creditbearing lecture portion of a course, organized class sections (e.g., recitation and discussion sections, laboratory sections, etc.), which themselves are zero-credit, but which are required components of the overall course of instruction. A complete picture of total faculty teaching activity-credit hours and course sections - is essential to any discussion of a possible relationship between teaching productivity and cost.

Cost data collected in Part B reflect direct expenditures for instruction and separately budgeted research and public service. The decision to focus on direct costs is related to the consistency in definitions as to what constitutes instruction, research, and service expenditures.
Long-standing definitions and calculation conventions for direct expenditures, as established by the National Association of College and University Business Officers (NACUBO) are used to develop information on instructional costs. These definitions are equally appropriate for, and applicable to a complex research university or a small baccalaureate liberal arts college.

The present study examines three cycles of Delaware Study data (i.e., 1998, 2000, and 2001) to identify those factors that are associated with the variation in direct instructional costs between and across academic disciplines, and to identify those cost factors that are tied to the magnitude of instructional expenditures in a given discipline. This examination takes place within the context of intervening variables such as Carnegie classification (a proxy for mission), highest degree offered in a discipline, and the relative emphasis on undergraduate versus graduate instruction in the discipline. 


\section{ANALYTICAL FRAMEWORK}

\section{Data Source: The Delaware Study of Instructional Costs and Productivity}

The data analyzed in this study were collected from multiple cycles of the Delaware Study of Instructional Costs and Productivity, and reflect information for the years 1997-98, 1999-2000, and 2000-2001. Data are collected annually using the template found in appendix B. The complete set of data definitions associated with each element in the template is found in the glossary (appendix C).

The purpose of this study is to examine whether instructional costs vary across disciplines within an institution, and across disciplines when institutions are arrayed by Carnegie classification. The Delaware Study utilizes the 1995 Carnegie taxonomy, which aggregates 4-year institutions into research universities, doctoral universities, comprehensive colleges and universities, and baccalaureate colleges (see appendix $\mathrm{C}$ for complete definitions). An institution's classification is based upon the volume and type of degrees granted, and the volume of externally funded research activity measured in terms of federal research and development expenditures.

The study further assesses the extent to which highest degree offered within a discipline (bachelor's, master's, or doctorate) and the relative emphasis on undergraduate versus graduate instruction in a discipline impacts cost patterns.

The model developed to analyze costs in this study focuses on direct expenditures for instruction. The instructional function is fully described and defined in the glossary to this report, as are those cost components that constitute direct expenditures. Instructional expenditures include salaries and wages, benefits, equipment, and other support costs that are dedicated to the instructional function, which embraces teaching, departmentally supported research, and other support activity designed to enhance the teaching process. Unit cost for purposes of this study is measured in terms of direct instructional expenditures per student credit hour taught within each of the disciplines under analysis.

A number of variables are considered in this study as potential factors associated with instructional costs. Faculty are classified into four faculty categories - tenured and tenure-track faculty, other regular faculty, supplemental or adjunct faculty, and graduate teaching assistants (see the glossary). Faculty type may be a cost factor if tenured and tenure-track faculty are more expensive than nontenurable full-time faculty and part-time adjuncts or teaching assistants. The size of an academic department or program faculty is measured by total full-time equivalency for each of the four faculty categories. The metric for calculating fulltime equivalency is described in the glossary.

Teaching activity is measured by student credit hours taught - in total, and within each faculty category. Student credit hour generation is measured at the lower division and upper division levels within undergraduate instruction, and in total at the graduate level. Within each discipline, instructional activity is also characterized by the highest degree awarded. Student credit hours and other characteristics of faculty teaching load are described in the glossary.

The cost model developed for this study examines the relationship of individual variables, and combinations of variables, with direct expenditures for instruction. The techniques for transforming collected data elements into specific data variables are fully described in the Findings section of this report. Specifically, the model employs appropriate statistical tools to test the following:

- The extent to which variation in instructional costs is associated with discipline and with 
institutional mission, as expressed by Carnegie classification.

- The extent to which specific variables are associated with direct instructional expense. The rationale for including these variables is described in the Technical Notes (appendix E). These variables are as follows:

1. Economies of scales as measured by the volume of student credit hours taught by a faculty of fixed size.

2. Variation in the total size of a faculty.

3. The proportion of total faculty who hold tenure. Tenured faculty tend to be better compensated, and are essentially "fixed costs" until retirement.

4. The proportion of total instructional expense that is accounted for by personnel expenditures.

5. The relative emphasis on undergraduate versus graduate instruction within a department's student credit hour production.

The apparent relationships between and across these variables are fully described in the Findings section of this report.

\section{Bias Issues in the Data}

Since its inception, participation in the Delaware Study has been restricted exclusively to 4-year colleges and universities. Although participating institutions self-select and the participant pool is not random, a general invitation to submit data is sent annually to presidents, chief academic officers, and institutional researchers through professional organizations such as the National Association of State Universities and Land Grant Colleges (NASULGC), the American Association of State Colleges and Universities (AASCU), the Association for Institutional Research (AIR), and the Society for College and University Planning
(SCUP). Working relationships have also been established with the Association of American Universities Data Exchange (AAUDE), the Southern Universities Group (SUG), the Big 12 Universities, and the Higher Education Data Sharing Consortium (HEDS), the latter embracing 125 private colleges and universities across the United States. The Delaware Study is also the official data collection vehicle for several state entities, including the University of North Carolina System, the Tennessee Board of Regents, the Louisiana Board of Regents, the Mississippi Board of Regents, and the South Dakota Board of Regents, among others. Table 2 displays institutional participation for the five most recent data collection cycles.

One of the assumptions examined in this study is that expenditure patterns and faculty workloads are, at least in part, tied to the institution's mission, i.e., the range of program offerings, the extent of commitment to graduate education, and the priority given to research and public service. The 1995 Carnegie classification category that groups institutions according to these institutional characteristics became the subpopulation that the participating institutions were to represent.

Table 2 shows a steady annual participation in the Delaware Study of roughly 150 institutions per year, except in 1999 when participation was restricted to research and doctoral universities while a secure web site was tested for use for online collection of data and dissemination of benchmarks. This relatively stable participation rate persists even though invitations to submit data were sent in summer 2001 to all Title IV-eligible 4-year institutions in the United States.

This consistent group of roughly 150 institutions over the years comprises about 4 in 10 research universities and 1 in 4 doctoral universities. The proportion of comprehensive and baccalaureate institutions is lower, because the base number of those institutions in the United States is much larger than that for research and doctoral universities. The 2000 data collection cycle, for example, embraced 152 institutions and 5,140 secondary analysis units, i.e., all disciplines at the 
Table 2. Number of institutions participating in the Delaware Study, by Carnegie institutional classification, by year: 1997-2001

\begin{tabular}{|c|c|c|c|c|c|}
\hline \multirow{2}{*}{ Carnegie classification } & \multicolumn{5}{|c|}{ Data collection cycle } \\
\hline & 1997 & 1998 & $1999^{1}$ & 2000 & 2001 \\
\hline Total ..................................... & 150 & 150 & 97 & 152 & 175 \\
\hline 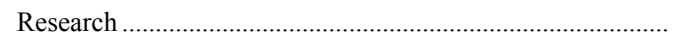 & 48 & 48 & 53 & 48 & 46 \\
\hline Doctoral & 36 & 27 & 25 & 27 & 34 \\
\hline 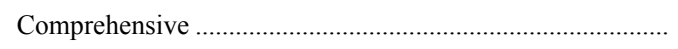 & 53 & 61 & 12 & 64 & 72 \\
\hline 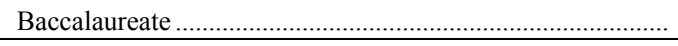 & 13 & 14 & 7 & 13 & 23 \\
\hline \multicolumn{6}{|c|}{$\begin{array}{l}\text { 1 In 1999, participation was restricted to research and doctoral institutions, except in cases where entire state higher education systems utilize the } \\
\text { Delaware Study. }\end{array}$} \\
\hline \multicolumn{6}{|c|}{ SOURCE: University of Delaware, The Delaware Study of Instructional Costs and Productivity, 1998-2001. } \\
\hline
\end{tabular}

4-digit CIP level. With the exception of a few institutions every year, there is complete enumeration of the discipline data by institution. The primary and secondary analytical units are generally similar for all data collection cycles.

\section{Analysis of Nonresponse Bias}

While numbers within the 1995 Carnegie categories vary slightly from year to year, institutional counts from the Integrated Postsecondary Education Data System (IPEDS) indicate that the following numbers reflect the total approximate size of each Carnegie grouping: 125 research universities, 110 doctoral universities, 525 comprehensive institutions, and 630 baccalaureate colleges. The counts do not include specialized 4-year institutions. The rate of participation over the years in the Delaware Study has been highest among research universities, with roughly 4 in 10 participating nationally. Approximately 1 in 4 doctoral universities participate, and 10 to 13 percent of comprehensive institutions submit data in any given year. The lowest participation rate is among baccalaureate institutions, with 2 percent participating prior to the 2000 data collection, and just over 3 percent submitting data in the most recent data collection cycle. It should be noted that data are collected at the academic discipline level of analysis, with four-digit CIP codes being the identifying marker. As a result, it is apparent that larger, more complex institutions, with discrete departments and disciplines, are more likely to participate than smaller institutions that typically have multiplediscipline organizational structures.
In any survey data collection, the risk exists that estimates derived from participating institutions may differ from those that might have been derived from nonparticipants. In such circumstances, data derived from the study participants alone could potentially be biased estimates of the overall population of institutions. This is a particular concern in instances where participation rates are low, as in the case of comprehensive and baccalaureate institutions. Moreover, as noted, participants are self-selected, and the pool of institutions is not random.

To examine how different or similar the participant pools are when compared with nonparticipating institutions, selected institutional characteristics were obtained from the IPEDS database. Institutional characteristics pertaining to faculty size, enrollment levels, degrees conferred, and expenditures information are summarized in appendix tables D-1 through D-5 for each data collection cycle, 1997 through 2001 (although some institutions had incomplete IPEDS information, particularly in the area of institutional finances). The difference between the average for the selected variables for participants and nonparticipants is displayed, along with an estimate of the magnitude of bias. The difference is also presented in terms of percent, with the participant average as the base. The findings are as follows:

- Among the research universities, institutions participating in the Delaware Study are 9 to 13 percent larger than nonparticipants in terms of the number of faculty that are tenured, and are 6 to 11 percent larger in terms of total full- 
time faculty. Full-time-equivalent (FTE) enrollment at participating institutions is higher by 16 to 22 percent. Participants also tend to have a larger undergraduate enrollment than nonparticipants and a correspondingly larger number of baccalaureate degrees awarded. Student/faculty ratio, measured in terms of FTE enrollment per full-time faculty, is slightly higher at participating institutions. Research expenditures per FTE faculty are lower by one-third at participating institutions, but public service expenditures per FTE faculty are higher. The average scholarship and library expenditures per FTE enrollment are approximately 20 percent higher among participating institutions when averaged over the years.

- Among doctoral universities, institutions participating in the Delaware Study are larger, both in terms of the number of tenure-track and total faculty, and in terms of FTE enrollment. The student/faculty ratio, as measured in terms of FTE enrollment per fulltime faculty, is similar for participating institutions and nonparticipants. Undergraduate enrollment as a percentage of total enrollment is higher among participating institutions by 12 to 16 percent. Average instructional expenditures per FTE student are higher among nonparticipants, while average scholarship expenditures per FTE enrollment are higher among participating institutions.

- Among comprehensive institutions, those that participate in the Delaware Study have about one-third more tenure-track and total full-time faculty than nonparticipants. FTE enrollment among participating institutions is larger than among nonparticipants by 25 to 34 percent, although undergraduate enrollment as a proportion of the total is higher among participating institutions by only 2 to 4 percentage points. The student/faculty ratio, as measured in terms of FTE enrollment per full-time faculty, is consistently smaller for participating institutions by two to four students per faculty. Participating institutions vary by year in terms of instructional and academic support expenditures per FTE enrollment. In 1997, participants spent 8 percent less on instruction and 13 percent less on academic support than did nonparticipants, where in subsequent years they spent more.

- Among baccalaureate institutions, those that participate in the Delaware Study are larger than nonparticipants both in terms of tenuretrack faculty (17 to 53 percent) and total fulltime faculty (23 to 42 percent). FTE enrollment at participating institutions is higher than at nonparticipating institutions by 23 to 33 percent, although the average student/faculty ratio, as measured by FTE enrollment per full-time faculty, is similar for both groups. The composition of the participant pool varies from year to year in terms of instructional expenditures per FTE students, with spending higher than that of nonparticipants in two of the years examined, and less in two other years. Average scholarship expenditures per FTE student at participating institutions are substantially less than at nonparticipating institutions in the earlier data collection cycles.

The findings are consistent with the general observation over the years that participants in the Delaware Study are more likely to be larger, more organizationally complex institutions that lend themselves to a structure that largely embraces discrete single CIP code academic department or program structures. Smaller institutions, with organization structures that involve high levels of interdisciplinary instruction and multiple CIP codes within a department or program (e.g., humanities department, social sciences department, etc.) find it more difficult to disaggregate teaching loads and expenditure information into recommended reporting formats and are less likely to participate. Consequently, data analyses in this study cannot be used to estimate cost patterns at the national level. However, statistics can be applied to the participant pool to describe cost patterns across disciplines, and across institutions, and to describe the association of those variables with direct instructional expenditures. These findings, while not generalizable to the larger universe of higher education institutions, do provide a thorough description of cost behaviors, by discipline, at 
institutions participating in the Delaware Study and yield a framework for discussion of strategic approaches to cost analysis at other institutions.

It must be underscored that comparable cost and teaching productivity data currently do not exist for 2-year colleges, proprietary schools, and the vast majority of small, interdisciplinary-oriented liberal arts colleges. Consequently, the findings from this study cannot be extended to those institutions. However, by analyzing the data available from the Delaware Study, we can draw certain conclusions about differences that exist in cost patterns at larger, complex, mostly public 4-year institutions. While the Delaware Study participant pool represents a small proportion of the universe of higher education institutions, it also represents a substantial proportion of total higher education enrollment.

\section{Statistical Tools}

This study of higher education instructional expenditures is a descriptive analysis. Because the population for the study is self-selected, any generalization to the larger universe of 4 -year higher education institutions is not possible. However, application of appropriate statistical tools to the data from institutions that elect to participate in the Delaware Study can yield rich descriptive information about expenditure patterns and cost factors for those institutions.

As noted earlier, the focal variable for this study is unit cost, by academic discipline, as measured by direct instructional expense per student credit hour taught. Direct instructional expense per student credit hour taught is one of the national benchmarks produced annually. It is a calculated mean value for the data submitted by participants for two variables: total direct instructional expenditures divided by total student credit hours taught. However, as a national benchmark, this mean statistic is "refined" to correct for idiosyncratic values that may be submitted by any given institution. In analyzing the data within each data set, national benchmarks are computed through Windsorization. The initial step in the computation is the inclusion of all institutional responses with each Carnegie class for a given variable. From those total responses, an initial mean value is calculated. The responses are then further analyzed to identify those cases that are beyond two standard deviations above or below the initial mean. These cases are then defined as outliers and are excluded from the subsequent calculation of the refined mean. This conservative approach to benchmark construction was taken to ensure that no single or set of idiosyncratic responses exert undue influence on the calculation of a mean value or benchmark. The Windsorization process trims the tails of the distribution by specified percentiles. For example, in a normal distribution, a 5 percent trimmed mean excludes the smallest 5 percent and the largest 5 percent observations. Benchmarks are calculated only for those disciplines wherein a minimum of five institutional responses were submitted.

Table 3 displays the refined means for direct instructional expense per student credit hour taught for each of the academic disciplines examined in this study. The data are arrayed by Carnegie institution type for the years 1998, 2000, and 2001. The data demonstrate general stability over time within each Carnegie class in each discipline. It is evident that direct instructional expense varies across Carnegie class within each discipline, with research universities generally costing more than doctoral universities, which, in turn, are more expensive than comprehensive institutions. Baccalaureate institutions that elect to participate tend to be selective institutions that offer small classes, and this is reflected in their expense per credit hour data.

To further illuminate the dispersion of direct expenditures per student credit hour taught among participating institutions, benchmarks are produced annually that display the refined means, arrayed by quartile as well as Carnegie institution type. Table 4 illustrates the dispersion of those refined means for 2001 for the same academic disciplines as in table 3. Comparable patterns in all data collection cycles have been evident. The values displayed for the quartiles represent the point at which one-fourth, one-half, and three- 


\begin{tabular}{|c|c|c|c|c|c|c|c|}
\hline Discipline and institution type & 1998 & 2000 & 2001 & Discipline and institution type & 1998 & 2000 & 2001 \\
\hline \multicolumn{4}{|l|}{ Communication } & \multicolumn{4}{|l|}{ Geology } \\
\hline 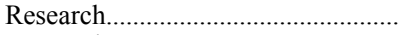 & $\$ 157$ & $\$ 164$ & $\$ 164$ & 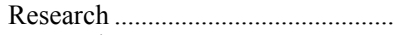 & $\$ 208$ & $\$ 223$ & $\$ 211$ \\
\hline 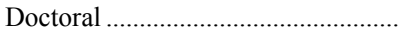 & 132 & 143 & 130 & 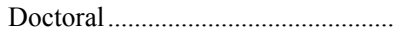 & 159 & 201 & 197 \\
\hline 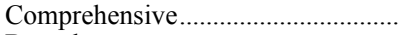 & 125 & 134 & 138 & 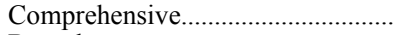 & 143 & 160 & 144 \\
\hline 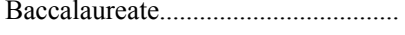 & 118 & 126 & 151 & 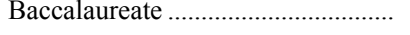 & --- & --- & --- \\
\hline \multicolumn{4}{|l|}{ Computer science } & \multicolumn{4}{|l|}{ Physics } \\
\hline 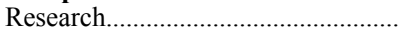 & 170 & 203 & 204 & Research ... & 249 & 284 & 263 \\
\hline Doctoral & 141 & 165 & 142 & 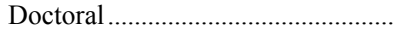 & 178 & 191 & 203 \\
\hline 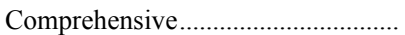 & 119 & 135 & 155 & 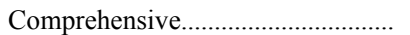 & 159 & 165 & 167 \\
\hline 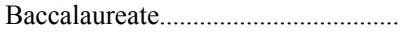 & 203 & 160 & 135 & Baccalaureate ............................................... & 235 & --- & 254 \\
\hline \multicolumn{4}{|l|}{ Education } & \multicolumn{4}{|l|}{ Psychology } \\
\hline 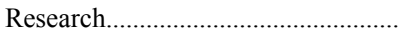 & 235 & 269 & 260 & Research ........... & 131 & 150 & 150 \\
\hline 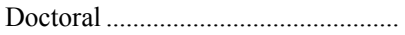 & 167 & 184 & 198 & 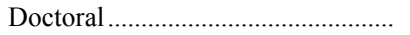 & 124 & 135 & 131 \\
\hline 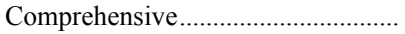 & 143 & 185 & 180 & 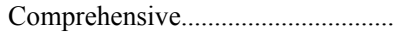 & 101 & 113 & 115 \\
\hline 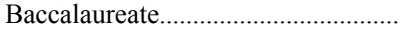 & 156 & 161 & 175 & Baccalaureate .............................................. & 126 & 113 & 131 \\
\hline \multicolumn{4}{|l|}{ Civil engineering } & \multicolumn{4}{|l|}{ Anthropology } \\
\hline Research..................... & 369 & 401 & 411 & Research ... & 139 & 148 & 157 \\
\hline Doctoral & 328 & 367 & 379 & Doctoral ................................................... & 118 & 127 & 126 \\
\hline 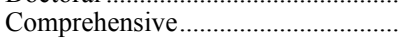 & 262 & 362 & 339 & 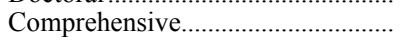 & 106 & 106 & 132 \\
\hline 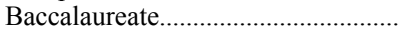 & --- & --- & --- & 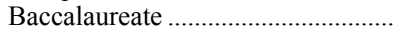 & --- & --- & --- \\
\hline \multicolumn{4}{|l|}{ Electrical engineering } & \multicolumn{4}{|l|}{ Economics } \\
\hline Research.............................. & 360 & 358 & 358 & Research. & 134 & 145 & 154 \\
\hline Doctoral & 273 & 318 & 276 & 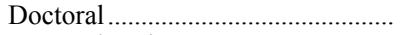 & 142 & 139 & 144 \\
\hline 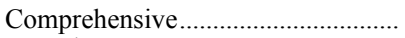 & 255 & 278 & 301 & Comprehensive & 102 & 112 & 126 \\
\hline Baccalaureate. & --- & --- & --- & 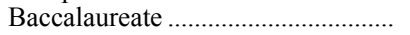 & 162 & --- & 194 \\
\hline \multicolumn{4}{|l|}{ Mechanical engineering } & \multicolumn{4}{|l|}{ Geography } \\
\hline 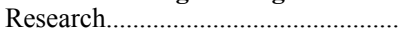 & 415 & 400 & 379 & Research ... & 140 & 155 & 164 \\
\hline 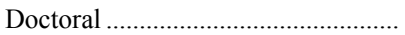 & 321 & 353 & 316 & Doctoral....... & 119 & 137 & 125 \\
\hline Comprehensive & 264 & 333 & 342 & Comprehensive & 95 & 121 & 103 \\
\hline 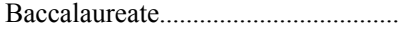 & --- & --- & --- & Baccalaureate …...................................... & --- & --- & -- \\
\hline \multicolumn{4}{|l|}{ Foreign languages } & \multicolumn{4}{|l|}{ History } \\
\hline Research....................... & 165 & 169 & 171 & Research & 129 & 142 & 149 \\
\hline Doctoral & 124 & 127 & 131 & 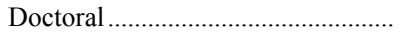 & 139 & 125 & 124 \\
\hline 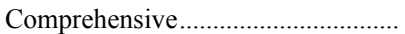 & 134 & 139 & 147 & Comprehensive & 105 & 99 & 103 \\
\hline 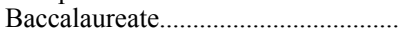 & 186 & 128 & 202 & Baccalaureate & 108 & 107 & 151 \\
\hline \multicolumn{4}{|l|}{ English } & Political science & & & \\
\hline 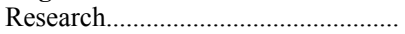 & 122 & 138 & 140 & Research .................... & 160 & 168 & 164 \\
\hline 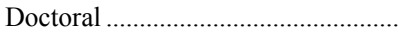 & 111 & 118 & 116 & 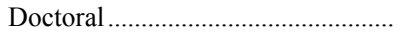 & 172 & 151 & 152 \\
\hline 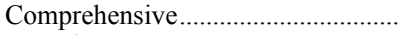 & 101 & 109 & 112 & 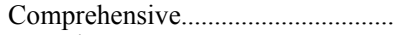 & 120 & 129 & 131 \\
\hline 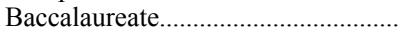 & 135 & 120 & 132 & 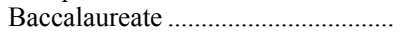 & 160 & --- & 165 \\
\hline Biological sciences & & & & Sociology & & & \\
\hline 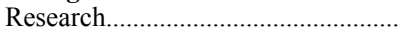 & 261 & 286 & 276 & Research .... & 108 & 130 & 124 \\
\hline 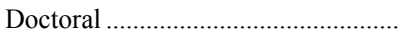 & 167 & 201 & 191 & 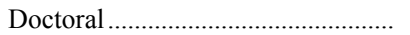 & 122 & 105 & 106 \\
\hline Comprehensive & 120 & 135 & 149 & 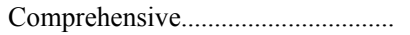 & 96 & 99 & 100 \\
\hline 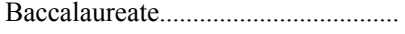 & 151 & 173 & 186 & 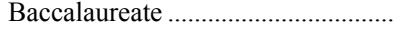 & 130 & 110 & 138 \\
\hline Mathematics & & & & Visual and performing arts & & & \\
\hline 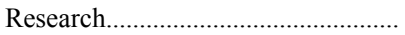 & 144 & 147 & 160 & Research & 205 & 214 & 228 \\
\hline 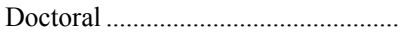 & 113 & 122 & 116 & 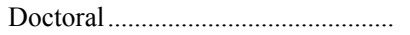 & 193 & 200 & 199 \\
\hline 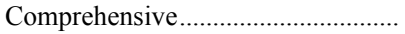 & 104 & 105 & 106 & 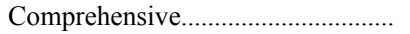 & 175 & 174 & 180 \\
\hline 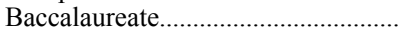 & 97 & 111 & 112 & 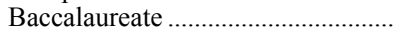 & 207 & 174 & 226 \\
\hline Philosophy & & & & Nursing & & & \\
\hline Research....... & 124 & 134 & 137 & Research & 300 & 368 & 388 \\
\hline Doctoral & 138 & 130 & 125 & Doctoral.... & 270 & 354 & 332 \\
\hline 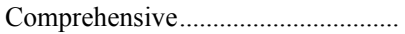 & 108 & 112 & 119 & 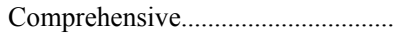 & 247 & 316 & 318 \\
\hline 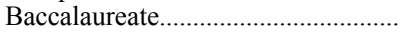 & 124 & 105 & 146 & Baccalaureate ......................................... & --- & --- & --- \\
\hline Chemistry & & & & Business & & & \\
\hline 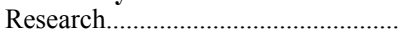 & 205 & 255 & 264 & Research .. & 161 & 167 & 170 \\
\hline 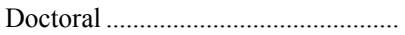 & 197 & 229 & 233 & Doctoral ................................................... & 149 & 164 & 157 \\
\hline 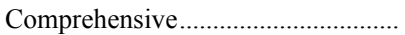 & 157 & 168 & 181 & Comprehensive & 150 & 151 & 156 \\
\hline Baccalaureate. & 189 & 190 & 242 & 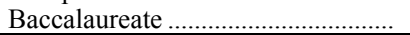 & 138 & 118 & 119 \\
\hline
\end{tabular}


Table 4. Direct instructional expense per student credit hour taught in selected academic disciplines, by Carnegie institution type, by quartile: 2001

\begin{tabular}{|c|c|c|c|c|c|c|c|}
\hline Discipline and institution type & $\begin{array}{r}25 \\
\text { percent }\end{array}$ & $\begin{array}{r}50 \\
\text { percent }\end{array}$ & $\begin{array}{r}75 \\
\text { percent }\end{array}$ & Discipline and institution type & $\begin{array}{r}25 \\
\text { percent }\end{array}$ & $\begin{array}{r}50 \\
\text { percent }\end{array}$ & $\begin{array}{r}75 \\
\text { percent } \\
\end{array}$ \\
\hline Communication & & & & Geology & & & \\
\hline 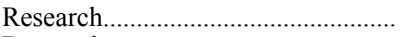 & $\$ 107$ & $\$ 159$ & $\$ 214$ & 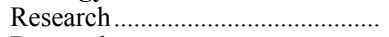 & $\$ 159$ & $\$ 209$ & $\$ 278$ \\
\hline 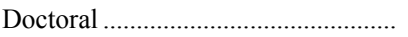 & 96 & 118 & 161 & 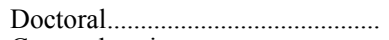 & 113 & 176 & 254 \\
\hline Comprehensive ................................... & 97 & 137 & 169 & 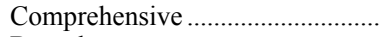 & 112 & 138 & 175 \\
\hline Baccalaureate.......................................... & 115 & 146 & 203 & 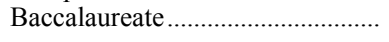 & --- & --- & --- \\
\hline Computer Science & & & & Physics & & & \\
\hline Research................... & 158 & 181 & 256 & Research.. & 189 & 254 & 340 \\
\hline 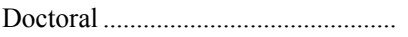 & 95 & 140 & 182 & Doctoral................ & 131 & 199 & 256 \\
\hline Comprehensive ................................ & 112 & 137 & 190 & Comprehensive ................................ & 115 & 163 & 208 \\
\hline 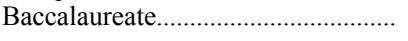 & 103 & 120 & 176 & Baccalaureate ................................... & 127 & 163 & 436 \\
\hline Education & & & & Psychology & & & \\
\hline Research..... & 181 & 243 & 322 & Research...... & 106 & 150 & 185 \\
\hline 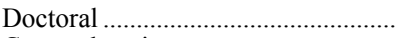 & 129 & 194 & 246 & 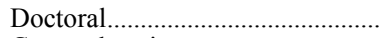 & 92 & 136 & 158 \\
\hline 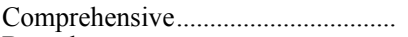 & 119 & 161 & 223 & 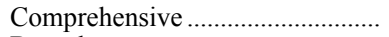 & 88 & 112 & 131 \\
\hline Baccalaureate......................................... & 125 & 161 & 322 & Baccalaureate ................................... & 90 & 121 & 150 \\
\hline Civil engineering & & & & Anthropology & & & \\
\hline Research.................... & 273 & 403 & 485 & Research............. & 117 & 159 & 191 \\
\hline 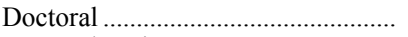 & 316 & 394 & 468 & 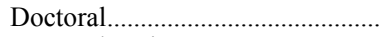 & 72 & 122 & 154 \\
\hline 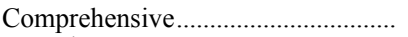 & 281 & 336 & 412 & 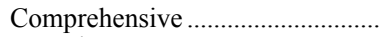 & 106 & 127 & 165 \\
\hline 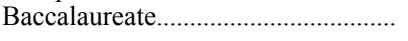 & --- & --- & --- & Baccalaureate ................................... & 105 & 136 & 260 \\
\hline Electrical engineering & & & & Economics & & & \\
\hline 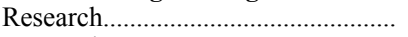 & 307 & 338 & 437 & Research...... & 112 & 144 & 192 \\
\hline 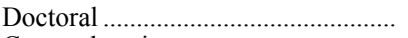 & 204 & 252 & 334 & 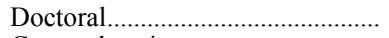 & 112 & 150 & 170 \\
\hline Comprehensive ........................................ & 230 & 292 & 391 & 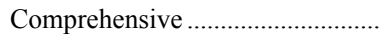 & 101 & 127 & 146 \\
\hline Baccalaureate......................................... & --- & --- & --- & Baccalaureate ....................................... & 134 & 199 & 232 \\
\hline Mechanical engineering & & & & Geography & & & \\
\hline Research.............................. & 302 & 382 & 455 & Research...... & 122 & 140 & 229 \\
\hline 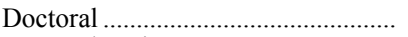 & 224 & 286 & 405 & Doctoral.. & 97 & 127 & 148 \\
\hline 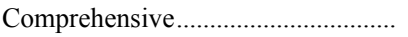 & 264 & 347 & 414 & 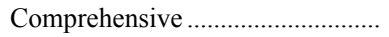 & 75 & 110 & 133 \\
\hline 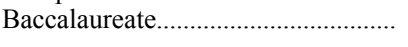 & --- & --- & --- & Baccalaureate ..................................... & --- & --- & --- \\
\hline Foreign languages & & & & History & & & \\
\hline 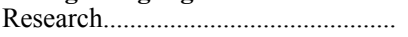 & 115 & 146 & 207 & Research.. & 113 & 150 & 188 \\
\hline 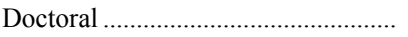 & 97 & 124 & 149 & Doctoral..................... & 81 & 125 & 163 \\
\hline 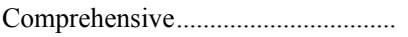 & 118 & 146 & 172 & 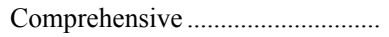 & 77 & 101 & 126 \\
\hline 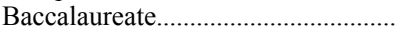 & 124 & 160 & 256 & Baccalaureate ................................... & 93 & 114 & 243 \\
\hline English & & & & Political science & & & \\
\hline 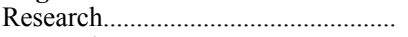 & 109 & 131 & 169 & 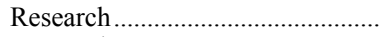 & 127 & 159 & 198 \\
\hline 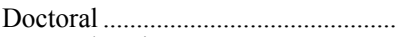 & 86 & 115 & 144 & 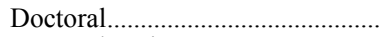 & 97 & 152 & 209 \\
\hline 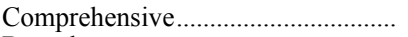 & 88 & 105 & 128 & 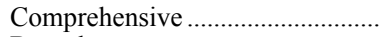 & 107 & 124 & 149 \\
\hline Baccalaureate.......................................... & 105 & 120 & 149 & Baccalaureate ....................................... & 103 & 186 & 211 \\
\hline Biological Sciences & & & & Sociology & & & \\
\hline Research................... & 194 & 236 & 333 & Research... & 105 & 119 & 153 \\
\hline 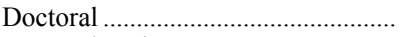 & 125 & 175 & 233 & 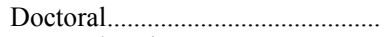 & 76 & 104 & 131 \\
\hline 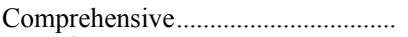 & 113 & 148 & 182 & 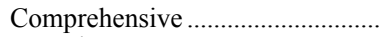 & 74 & 95 & 125 \\
\hline 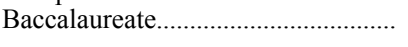 & 150 & 165 & 205 & Baccalaureate ................................... & 92 & 135 & 192 \\
\hline Mathematics & & & & Visual and performing arts & & & \\
\hline 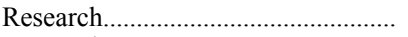 & 103 & 137 & 195 & 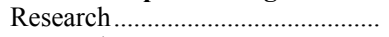 & 160 & 217 & 280 \\
\hline 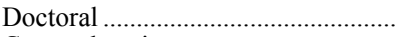 & 83 & 120 & 136 & 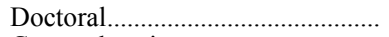 & 141 & 189 & 253 \\
\hline Comprehensive ................................ & 83 & 113 & 128 & Comprehensive ................................ & 129 & 166 & 221 \\
\hline 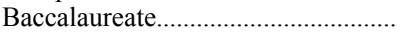 & 80 & 111 & 140 & 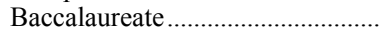 & 176 & 201 & 283 \\
\hline Philosophy & & & & Nursing & & & \\
\hline 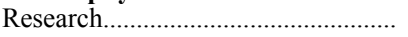 & 93 & 138 & 180 & 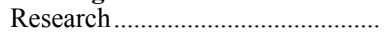 & 309 & 403 & 468 \\
\hline 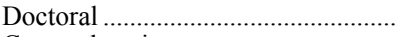 & 96 & 123 & 145 & 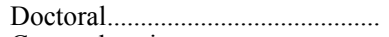 & 240 & 341 & 403 \\
\hline Comprehensive ................................. & 92 & 122 & 140 & Comprehensive ................................ & 242 & 291 & 373 \\
\hline Baccalaureate ...................................... & 78 & 140 & 203 & Baccalaureate ................................... & --- & --- & --- \\
\hline Chemistry & & & & Business & & & \\
\hline Research...... & 208 & 244 & 324 & Research...................... & 125 & 166 & 207 \\
\hline 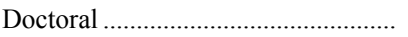 & 164 & 241 & 266 & 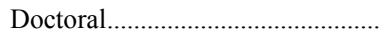 & 122 & 154 & 185 \\
\hline 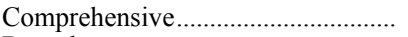 & 128 & 171 & 221 & 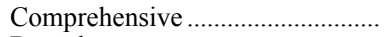 & 124 & 149 & 188 \\
\hline Baccalaureate................................ & 160 & 223 & 302 & Baccalaureate ............................. & 95 & 110 & 146 \\
\hline
\end{tabular}

SOURCE: University of Delaware, The Delaware Study of Instructional Costs and Productivity, 1998-2001. 
quarters of participating institutions, respectively, reported costs equal to or below those values.

The data in displayed table 3 indicate modest variation across Carnegie institutional categories within a discipline, but also indicate that larger and more substantial differences exist between and across the disciplines within institution types. These patterns are consistent in examining the dispersion of data points in table 4 , thereby raising one of the focal questions for this study: Which is more central to understanding the variation of instructional costs in higher education-differences within disciplines examined across institutions, or differences between disciplines within institutions?

As important as describing the factors that are associated with the dispersion of instructional costs within and across institutions is an understanding of those factors that are tied to expenditures within academic disciplines. Multiple regression techniques were applied to a full range of variables that potentially are associated with the magnitude of direct instructional expenditures. Using direct expense per student credit hour taught as the dependent variable, potential cost factors, including but not limited to the following, were examined:
- Volume of teaching load as measured in terms of student credit hours taught;

- Size of instructional faculty, measured in terms of full-time equivalency;

- The proportion of total FTE faculty that are tenured or tenure track (predicated on the assumption that tenured and tenure-track faculty are better compensated than other faculty);

- The relative emphasis of departmental teaching on undergraduate versus graduate instruction; and

- The extent to which an academic discipline is personnel-intensive as compared to equipment-intensive.

The application of multiple regression techniques to the variables in this study is described in appendix E. The Findings section of this study describes the results of the application of both HLM and multiple regression statistics to the data, and clearly identifies those factors that are associated with the dispersion of instructional expenditures within and across institutions, and those factors that are associated with the magnitude of direct instructional expense in academic disciplines. 
Two major issues are addressed in this Study of Higher Education Instructional Expenditures. The first is whether important differences in direct instructional costs are evident between and across the disciplines within an institution and across institutions within Carnegie category. The second issue is the identification of important cost factors within the disciplines under analysis. This section of the report details findings growing out of analyses of three Delaware Study data collection cycles that speak to those issues.

\section{Variation in Cost Across and Within Institutions}

To establish the variance components of cost through hierarchical linear modeling (HLM), disciplines are considered the level 1 units and institutions the level 2 units. Without taking into account any institutional or discipline-related variables, the hierarchical linear model is equivalent to one-way ANOVA with random effects. This approach provides information on how much of the variation in cost lies across or within institutions, a test of whether the institutional average costs are the same, and a measure of each institution's calculated average cost.

Results from the model are presented in table 5 for three data collection cycles. The data indicate that most of the variation occurs at the discipline level. In the 1998 data collection cycle, disciplines within institutions were tied to 76 percent of the total variance. In 2000, disciplines were associated with 82.6 percent of the variance. In 2001, disciplines within institutions were tied to 81.3 percent of the total variance, while institutions were linked to 18.7 percent. The results also show that there are mean differences in cost by institution in all three data sets.
The last column in the table refers to reliability of average cost by institution. If the data set used in this study were a random sample, these numbers would indicate whether or not the average cost for each institution is reliable estimates of true average cost. Since the data are not random, all that can be said about these reliability estimates is that the average cost of instruction estimated by the hierarchical linear model for the three data cycles can be deemed reliable for the participating institutions. Within that context, the reliability estimates are high, ranging from 86.3 percent in the 1998 data set to 80.7 percent in 2000 , and 81.3 percent in the 2001 data set.

The second panel in table 5 presents Delaware Study results from the hierarchical linear model after accounting for the Carnegie classification of the institution (level 2). If it is assumed that Carnegie classification is tied to some of the variations in cost at the institutional level, then incorporating it at level 2 of the model will reduce the variance in cost due to institutions. As the table indicates, Carnegie classification is tied to some of the variation in cost at the institutional level. While the one-way ANOVA model with random effect indicated that in the 2001 data collection cycle, institutions were tied to 18.7 percent of the variance, this second model reduces this to 14.2 percent, meaning that the variance in cost among schools within the same Carnegie classification is 14.2 percent. This is equivalent to a 28 percent reduction in the variance among institutions after accounting for the Carnegie groupings of those institutions. There is a 35.2 percent and 25.5 percent variance reduction in the 2000 and 1998 data collection cycles, respectively. As the result of the variance reduction across institutions, the variance within institutions in relative terms increased from 81.0 percent in 1998 to 88.0 percent in 2000 , and 85.8 percent in 2001 . 


\begin{tabular}{|c|c|c|c|c|c|c|c|}
\hline Data collection model & Random effect & $\begin{array}{r}\text { Variance } \\
\text { component }\end{array}$ & $\mathrm{df}$ & Chi-square & $P$ value & $\begin{array}{r}\text { Variance } \\
\text { component } \\
\text { (percent) }\end{array}$ & $\begin{array}{r}\text { Reliability } \\
\text { of } \\
\text { institution } \\
\text { average } \\
\text { cost } \\
\text { (percent) }\end{array}$ \\
\hline \multicolumn{8}{|c|}{ I. One-way ANOVA model } \\
\hline \multirow[t]{2}{*}{1998} & Institution & 2,144 & 126 & 1,031 & * & 24.0 & 86.3 \\
\hline & 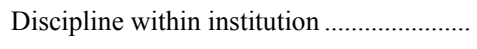 & 6,807 & & & & 76.0 & \\
\hline \multirow[t]{2}{*}{2000} & 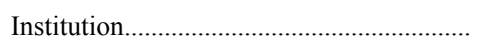 & 1,787 & 133 & 779 & * & 17.4 & 80.7 \\
\hline & 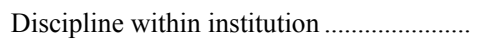 & 8,460 & & & & 82.6 & \\
\hline \multirow[t]{2}{*}{2001} & Institution & 1,737 & 157 & 969 & * & 18.7 & 81.3 \\
\hline & Discipline within institution ........................ & 7,540 & & & & 81.3 & \\
\hline \multicolumn{8}{|c|}{ II. With fixed effect of Carnegie classification of institution } \\
\hline \multirow[t]{2}{*}{1998} & Institution & 1,597 & 123 & 783 & * & 19.0 & 82.6 \\
\hline & Discipline within institution ............................ & 6,810 & & & & 81.0 & \\
\hline \multirow[t]{2}{*}{2000} & 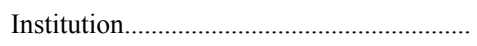 & 1,158 & 130 & 560 & * & 12.0 & 73.5 \\
\hline & Discipline within institution .......................... & 8,459 & & & & 88.0 & \\
\hline \multirow[t]{2}{*}{2001} & Institution & 1,251 & 154 & 748 & * & 14.2 & 76.1 \\
\hline & Discipline within institution .......................... & 7,540 & & & & 85.8 & \\
\hline \multicolumn{8}{|c|}{$\begin{array}{l}\text { III. With fixed effect of Carnegie class of institution and fixed effect of } \\
\text { the discipline groupings }\end{array}$} \\
\hline \multirow[t]{2}{*}{1998} & Institution & 1,788 & 123 & 1,484 & * & 32.8 & 90.6 \\
\hline & Discipline within institution .......................... & 3,669 & & & & 67.2 & \\
\hline \multirow[t]{2}{*}{2000} & Institution & 1,352 & 130 & 1,094 & * & 23.7 & 85.7 \\
\hline & 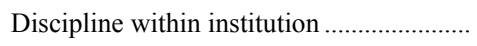 & 4,361 & & & & 76.3 & \\
\hline \multirow[t]{2}{*}{2001} & Institution & 1,569 & 154 & 1,478 & * & 28.5 & 87.9 \\
\hline & Discipline within institution ....................... & 3,939 & & & & 71.5 & \\
\hline
\end{tabular}

$* \mathrm{p}<0.05$.

NOTE: Degrees of freedom for the variance component of discipline within institution are not generated from output for hierarchical linear modeling. Similarly, since discipline within institution variance is the error term, there should be no entries in the Chi-square and $p$ value columns.

SOURCE: University of Delaware, The Delaware Study of Instructional Costs and Productivity, 1998-2001.

Examining cost by discipline over the three data collection cycles consistently showed that there is a general and reasonable grouping of disciplines according to cost levels. Service departments such as English and mathematics are among those with the lowest instructional costs, and their costs are comparable with those on the social sciences. Instructional costs in the physical sciences are in the next highest level and are comparable to those in education, business, and art. Costs are highest in engineering and nursing. These three groupings were used as indicator variables for disciplines (level 1) in the hierarchical linear model to understand how much reduction in the variance across disciplines is evident. In this model, the fixed effect of Carnegie classification is retained. The results are summarized in the bottom panel of table 5.

Inclusion of the discipline grouping reduced the variance among disciplines by 48 percent in the 2001 and 2000 data cycles, and by 46 percent in the 1998 data set. In spite of the reduction, however, the resulting variance among disciplines 
in relative terms remained at high levels of over 70 percent in the 2001 and 2000 data cycles, and 67 percent in the 1998 data set.

While there are numerous variables that can be considered in the model to reduce the variance among disciplines (level 1), analysis was restricted to the aforementioned discipline groupings. Relationships between cost and other variables that may be tied to expenditures are discussed in a subsequent section of these Findings.

\section{Differences in Costs Between and Across Disciplines}

Preliminary examination of the data suggested the necessity of combining the data from comprehensive and baccalaureate institutions, owing to very small participation rates for baccalaureate colleges within the disciplines and to eliminate the possibility of having unbalanced factors. While differences in average cost between comprehensive and baccalaureate institutions may exist for some disciplines, it can be argued from a purely practical approach, this combination of institutions is consistent with real-world practice at colleges and universities. While some level of graduate instruction is present in a few selected disciplines at comprehensive institutions, the vast majority of teaching activity and student credit hour generation occurs at the undergraduate level. It is, therefore, reasonable to group comprehensive and baccalaureate institutions, given their common primary undergraduate teaching mission.

Because of the nature of the data, there is large variation in the number of cases in each of the cells (i.e., combination of discipline and Carnegie classification). Costs for some of the disciplines are estimated from fewer than 10 courses, which can result in failure to find differences in means when differences, in fact, exist. In addition, the Levene test, which is the standard test of homogeneity of variance, indicated that the variances among the cells are not equal. After careful examination of the variances, the cost data were transformed to logarithm for the ANOVA. Although the variances remained unequal even after the transformation, the Levene test indicated that the inequality of the variances was substantially reduced. Therefore, ANOVA was used on the logarithm of cost.

The ANOVA showed that there are differences in costs among the 25 disciplines under examination, and among the now-three institutional groupings-research universities, doctoral universities, and comprehensive/baccalaureate institutions. Because there is strong interaction between discipline and Carnegie classification, the differences in cost across the disciplines are examined separately by Carnegie classification, and vice versa.

It should be noted that before ANOVA was applied to the data, outliers were identified in each of the cells, e.g., discipline by Carnegie classification. Outliers were defined as data points that lie beyond two standard deviations from the mean for the cell, and were subsequently omitted. The summary of the ANOVA to test for differences in average cost of instruction by discipline, and by Carnegie classification, by highest degree offered, and by undergraduate/ graduate program mix in discipline for the 2001, 2000 , and 1998 data collection cycles is found in appendix table D-6.

The results of the ANOVA by discipline and Carnegie classification are presented in appendix table D-7 for the 2001 data collection cycle, appendix table D-8 for the 2000 data collection cycle, and appendix table D-9 for the 1998 data collection cycle. The results of the pair-wise multiple comparisons are based on the Bonferroni procedure at the 5 percent level of significance. In the tables, the disciplines are sorted in ascending order of cost within each Carnegie classification. Then, groupings of disciplines are presented according to similarity in cost based on results from the pair-wise multiple comparisons. Disciplines that are defined as belonging to a group are assigned similar letters. For example, for research institutions in appendix table D-7, sociology through business are members of the "a" group. As such, there are no two disciplines in this group, regarding average cost of instruction, where differences were detected through ANOVA, even though the absolute values of those average costs range from $\$ 124$ to $\$ 177$. Business belongs 
to the "b" group as well, meaning that with respect to the cost of instruction, differences were not found between business and the other disciplines in group "b." Business, as a member of group "c," also shows no differences between its cost and the other disciplines in "c" group. Since business does not belong to the " $\mathrm{d}$ " group, cost in business is lower than that in education and the remaining disciplines listed below education.

The strong interaction between discipline and Carnegie groups, as expected, produced somewhat different discipline groupings for each category. The general findings are as follows:

- Among research institutions, differences were not detected between and among "service" departments such as English and mathematics, as well as disciplines in the social sciences, with respect to direct instructional expense per student credit hour taught. It costs as much to teach art (with small studio courses and individualized instruction) as it does to teach education (with a clinical teacher education component) and disciplines in the physical sciences (with emphasis on equipment intensive laboratory instruction). The high cost of teaching nursing puts it at the same levels as the engineering disciplines that have the highest unit costs. In the two more recent data sets, biology and physics have costs comparable to nursing and the engineering disciplines, with the exception of chemical engineering. It should be noted that costs in the engineering disciplines have the highest variability among reporting institutions.

- Cost of instruction in service departments and in the social sciences at doctoral universities tends to be at the same levels. Differences were not detected in the cost of instruction in the physical sciences compared with several of the social science disciplines. As at research universities, art groups with the physical sciences in cost, while nursing groups with engineering. This is likely associated with more expensive pedagogical delivery systems in art and nursing.

- Instructional costs at comprehensive/ baccalaureate institutions generally follow the patterns seen in the research and doctoral universities. Nursing groups with engineering with respect to instructional cost; education, art, and foreign languages group with the physical sciences. Again, this is likely tied to more costly pedagogical delivery systems in art, education, and nursing. English and mathematics, the two large service disciplines, group with the social sciences as the least expensive disciplines from an instructional cost perspective.

- Using the results from the same ANOVA, differences in costs were not detected among Carnegie groups for many disciplines. There are, however, a few disciplines, notably biology and education, wherein cost in research universities is higher than in doctoral and comprehensive institutions for all three data sets, and in mathematics and physics for the two more recent data sets. Costs in research universities are also found to be higher in the most recent data set in art, chemistry, computer science, and geography.

The analysis was extended to summarize variation in costs among the disciplines by highest degree offered within the discipline. As was the case with the preceding discipline analysis by Carnegie institution type, ANOVA was used on the logarithm of cost per student credit hour taught in order to reduce inequality of variance among the cells.

The results of the pair-wise multiple comparison of average instructional cost by discipline, within each highest degree offered category, are displayed in appendix tables D-10 to D-12 for the three data sets. Since the interaction between discipline and degree level is substantial, discipline groupings according to cost level are shown independently by highest degree offered. The results are as follows:

- Regardless of the highest degree offered, costs of instruction are lowest among service departments such as mathematics and English and all disciplines in the social sciences. Costs in art and education tend to be at similar levels as those in the physical sciences. 
- In general, physical science disciplines have higher instructional costs than the social sciences in those instances where the Ph.D. is the highest degree offered. Where the master's or bachelor's is the highest degree offered, no differences in instructional costs were detected between the physical sciences and social sciences disciplines.

- Differences were not found between the cost of instruction in business and the social sciences for programs where the Ph.D. is the highest degree offered, whereas instructional costs in business are more comparable to costs in the physical sciences at the master's and bachelor's programs.

- Generally, all disciplines in engineering and nursing have higher costs than all other disciplines for all three degree-granting levels.

- In biology, cost of instruction is different at each of the three degree-granting levels, and the pattern remains consistent in each of the three data sets examined. Differences in cost, by degree level, are also found in all three data sets in education, art, and geology, and in two data sets in mathematics and psychology.

The relative undergraduate/graduate program mix is measured by the number of bachelor's degrees awarded in a discipline as a proportion of total degrees awarded. The Delaware Study national benchmarks are reported by 25 -percentile ranges for undergraduate/graduate program mix, as defined. In the 2001 data collection cycle, those institutions where the proportion of undergraduate degrees is 75 percent or more of total degrees awarded account for 60 percent of the sample. With another 19 percent of the sample comprised of institutions granting 50 to 75 percent of all degrees at the undergraduate level, the sample sizes for institutions granting fewer than 50 percent of total degrees at the undergraduate level-in other words, predominantly graduate institutions - is very small. As a result, the sample size for many disciplines with predominantly graduate programs is small, and within that group, several disciplines were not represented at all. This distribution is very similar for the two earlier data collection cycles. Consequently, the entire sample was grouped into only two categories: 1) undergraduate degrees equivalent to 75 to 100 percent of total, and (2) undergraduate degrees equivalent to 0 to less than 75 percent of total.

The interaction between the program mix categories and discipline is both strong and important. The pair-wise multiple comparisons by discipline are, therefore, examined independently for the two groups, the results of which are presented in appendix Tables D-13 to D-15 for the three data sets. The ranking and grouping of instructional costs for these two groups follows the general patterns seen in the analyses by Carnegie institutional classification, and by highest degree offered within the discipline.

- For both program mix categories, service departments such as English and mathematics have the lowest instructional costs, and these costs are comparable to those in the social science disciplines.

- Differences in instructional costs were not detected between the physical sciences and several disciplines in the social science for both program mix categories.

- For the predominantly undergraduate programs, instructional costs for nursing are comparable to those in the engineering disciplines, and all have costs higher than other disciplines. Cost for biology at institutions with larger graduate programs is comparable to those in engineering disciplines.

Worth noting is the variation in cost among subdisciplines in education. The cost per student credit hour in the foregoing analysis is that for all education subdisciplines combined. A more indepth examination of cost within education showed that there are indeed variations between and among its subdisciplines (not shown in tables). Based on the 2000 dataset, direct expense per student credit hour taught ranged from $\$ 149$ in teacher education to $\$ 307$ in educational administration and supervision. Tests showed that instructional costs were lowest in discipline-based 
teacher education (e.g., social studies education, mathematics education, science education, etc.), while general teacher education and curriculum and instruction cost more, at an average of $\$ 186$ per student credit hour taught. As a group, teacher education costs are lower than the instructional cost for special education (\$205), and general education, educational research/evaluation/ statistics, educational psychology, student counseling, and instructional media design - all of which average $\$ 270$ per student credit hour taught. Educational administration and supervision at $\$ 307$ is more expensive than most other subdisciplines. It should be noted that educational administration and supervision is typically a graduate-level discipline, often with a doctoral component.

\section{Cost Factors}

The initial analytical step in A Study of Higher Education Instructional Expenditures was to identify factors associated with instructional expenditures within each of these 25 academic disciplines under examination. In examining the 25 disciplines within any given data collection cycle, it is imperative to ensure that sufficient data points are available to allow for reliable use of the multiple regression methodology. In certain instances, e.g., engineering, it is necessary to collapse disciplines into larger, naturally affiliated groupings in order to achieve sufficient data points.

Appendix table D-16 displays cost factors for 20 disciplines or groups of disciplines under examination from the 2001 data collection cycle. Four of those disciplines-chemical, civil, electrical, and mechanical engineering - have been collapsed into a single larger "engineering" grouping. Three disciplines-anthropology, geography, and political science-had insufficient data points for discrete analysis, and since all three are social science disciplines, they lend themselves to a larger grouping called "other social sciences." Similar groupings were done for the 2000 and the 1998 data collection cycles, the results of which are presented in appendix tables D-17 and D-18, respectively.
Cost factors, as listed in appendix table D-16, were examined for modeling purposes, and fall basically into four broad categories. The first category is measures of department size. Size is described in terms of the total FTE faculty, total FTE tenured and tenure-track faculty, and FTE instructional faculty (which adjusts for contractual buyouts of faculty time for research and service activity). The size of the tenured/tenure-track faculty as a proportion of total faculty is also considered as a cost indicator. Extensive use of adjunct, part-time faculty, who tend to be paid less well than regular faculty, may actually reduce total instructional expense. Another aspect of department size is the extent of the teaching activity in the department, as measured in terms of the academic year student credit hours taught at the undergraduate level and graduate level combined. The number of graduate student credit hours taught and as proportion as of the total student credit hours are also examined, as it is generally assumed that graduate instruction is more expensive than teaching undergraduates.

The second group of factors relate to teaching workload. Workload is described in terms of the average number of student credit hours taught per FTE instructional faculty at the undergraduate level and at the combined undergraduate and graduate levels. Workload for tenured and tenuretrack faculty is also examined in terms of student credit hours at each of the course levels as well as in terms of the proportion of student credit hours taught by them.

The proportion of total direct expenditures for instruction that is attributable to personnel costs is the third category of cost factors, while the fourth comprises variables that further describe the department in terms of highest degree offered in the discipline. The 1995 Carnegie classification is used to delineate types of institutions. Highest degree offered and the institution's Carnegie classification are transformed into categorical (dummy) variables for the analysis.

As described earlier, the analytical process for each of the disciplines was kept as consistent as possible. To recapitulate, the following protocols were adopted for all equations: 
- Cost per student credit hour taught is the dependent variable. Cost is transformed to logarithm in the analysis.

- Data points wherein unit cost is beyond two standard deviations from the mean are omitted at the onset of the analysis.

- Outliers are defined as those cases in which the absolute value of the standardized residual is three or higher, and are subsequently omitted.

- Influential cases are identified as those with relatively high values of Cook's Distance and/or Mahalanobis Distance statistics. These cases are omitted in the final analysis.

- The quadratic terms of all continuous variables are tested for inclusion in the model to account for possible nonlinear relationships with cost.

- Interaction terms between selected continuous variables and categorical variables (highest degree offered and Carnegie institutional classification) were tested for inclusion in the model. Note, however, that no interaction terms were important cost predictors in all three data sets, hence they are not listed in the summary.

- For disciplines that are a two-digit CIP aggregate (e.g., Communication, 09.XX), data points belonging to a four-digit subdiscipline with two or fewer institutions reporting were eliminated from the aggregation.

The tables display regression coefficients and their corresponding standardized values (Beta coefficients). Since the dependent variable was transformed to logarithm, each regression coefficient is the equivalent percent increase in cost for every unit change in the corresponding variable. The Beta coefficients allow direct comparison of the relative contribution of each variable in predicting cost. The adjusted $\mathrm{R}^{2}$ is the proportion of the variation in cost that is associated with the variables included in the equation, and is a measure of the goodness of fit of the equation. Some general observations are apparent from the three sets of analyses:

- Across almost all disciplines, the level of the department's teaching activity, as measured by total undergraduate and graduate student credit hours taught, is always associated with direct instructional expense. In the majority of disciplines, it has the highest or second highest contribution in predicting cost. Cost decreases as the volume of teaching increases. For many disciplines with a strong quadratic term, cost decreases at a faster rate at lower division levels of instruction. For engineering, art, business, and the combined political science/ anthropology/geography group, cost increases as the proportion of student credit hours that are offered at the graduate level increases.

- Departmental size (measured in terms of total number of faculty, total number of tenured/tenure-track faculty, or total number of instructional tenured/tenure-track faculty) is consistently associated with expense across disciplines. The larger the faculty size, the higher the cost. Its high explanatory power in predicting cost is evident in almost all disciplines.

- The proportion of faculty who are tenured or who are on tenure track among all instructional faculty, or among total faculty, is associated with cost, but to a lesser extent than the number of faculty. The higher this proportion, the higher the cost.

- Among the variables that measure faculty workload, the average student credit hours taught per FTE faculty is the most common cost factor among disciplines. The larger the number of credit hours taught, the lower the cost. Its relative contribution in describing cost variation is very high, if not the highest, in several disciplines. For some disciplines, regardless of magnitude of faculty workload, decrease in cost is constant. However, for many disciplines with a strong quadratic term, cost decreases at a faster rate when the teaching load is at lower levels than at higher levels. 
- Personnel expenditure as percent of total instructional expenditure is a cost factor in the majority of disciplines. The higher the percentage, the lower the cost. Its contribution in describing cost, however, is relatively low in equipment-intensive disciplines, such as engineering and the physical sciences, where there is a large added cost of instruction due to nonpersonnel expenses.

- For many disciplines, cost differentials exist depending on whether or not graduate degrees are offered in the program. With the faculty size and faculty workload being tied to much of the variation in cost, most often the relative contributions of the indicator variables for highest degree are relatively small. It is worth noting that in all three data collection cycles, doctoral instruction in biology, chemistry, and physics substantially increases cost by nearly 10 percent on average, which is not surprising for disciplines in the physical sciences, given the emphasis on small group laboratory and research activity at the Ph.D. level. Interestingly, doctoral instruction in philosophy also increased cost by 10 percent, likely associated with the faculty-intensive nature of small group instruction at the Ph.D. level, and because the other variables that measure the contrast between undergraduate and graduate instructional faculty workload did not directly affect cost. Average increase in cost for English is about 5 percent.

- The cost differential due to Carnegie classification of the institution is usually more evident in disciplines when the highest degree offered is not a cost factor. In business, Carnegie classification is a consistent cost indicator with its effects being stronger than in any other discipline. For example in the 2001 data collection cycle, costs are higher by 21 percent among research institutions, 18 percent higher among doctoral institutions, and 12 percent higher among comprehensive institutions than in baccalaureate institutions. Costs in nursing in research institutions are higher by almost 10 percent, on average, than in any other group of institutions; in the discipline of education, costs are higher by almost 6 percent on average than in any other group.

\section{Summary}

Two issues consistently emerge as the most crucial findings in this analysis of multiple cycles of Delaware Study data:

- Most of the variance in instructional costs across institutions, as measured by direct expense per student credit hour taught, is associated with the disciplinary mix within an institution. While there are differences in instructional costs within a discipline when examining cost per student credit hour taught across Carnegie classification, they are less important than the difference in instructional costs between and across the disciplines that compose the curriculum within an institution.

- The magnitude of instructional costs within a discipline can be predicted based upon the degree of presence or absence of certain identifiable cost factors, specifically, volume of teaching load as measured by student credit hours taught is negatively associated with cost, while size of a departmental faculty, tenure rate within that faculty, and to a lesser extent, the presence of graduate instruction are positively associated with cost. 


\section{CONCLUSIONS AND DISCUSSION}

\section{Conclusions}

Two central threads emerge from the analysis of data from the Delaware Study. First, there are real and important differences between instructional expenditures within the disciplines at a given institution. Second, it is possible to identify major factors that are tied to instructional expenditures across those disciplines.

Of foremost importance is the recognition that there are differences in cost between and across disciplines within an institution, and that these differences are associated with most of the variation when instructional costs are examined across institutions. The Delaware Study data collections have consistently revealed expenditure differences between and across disciplines ranging from a cost per student credit hour taught in the low $\$ 100$ s in the social sciences to in excess of $\$ 400$ in engineering and certain physical sciences. The following discussion will focus on the identification of factors that are tied to important differences among disciplines.

With certain exceptions, direct instructional expenditures do not vary substantially within a given discipline when viewed across Carnegie institutional types. It is the differential in expenditures between and across the disciplines within an institution that is substantial-and important. The data consistently demonstrate that on average, whether it is a major research university or a small baccalaureate college, certain disciplines are less costly than other disciplines at the same institutions. Service departments, i.e., those that satisfy general education requirements, such as English, mathematics, and the social sciences, are generally the least costly. Because they satisfy general education requirements, service departments are in high demand and tend to be major student credit hour producers, one of the primary factors associated with reducing instructional expenditures.
Other disciplines have consistently higher costs. Physical sciences and biology, especially where the doctorate is offered, are expensive disciplines. This also is not surprising, given the equipmentintensive nature of these disciplines and the need to offer small group laboratory sections. However, at nondoctoral institutions, some physical science disciplines are only marginally more expensive than social science departments. This is likely associated with introductory, nonmajor sections of chemistry and biology that frequently satisfy students' science requirements, and are typically offered in large lecture format, i.e., they are major student credit hour producers.

Three disciplines-art, nursing, and education-are consistently comparable to the physical sciences in terms of instructional expenditures. These disciplines, by nature, require intense individualized instruction, in addition to lectures. Art courses often contain a studio component with a faculty mentor guiding a small number of students. Education and nursing both have a practicum associated with instruction wherein students are placed in apprentice roles at clinical sites as part of their curriculum. This type of instruction is typically more expensive than the traditional large group lecture format found in social sciences and humanities programs.

The important disciplinary differences are between and across departments at an institution, regardless of Carnegie institutional category. The differential patterns generally hold, whether at a research university or a liberal arts college. However, certain disciplines, most notably business, display distinctly different cost patterns depending upon highest degree offered. At institutions that grant the Ph.D., instructional expenditures in business tend to group with the less expensive social sciences, while grouping with the more expensive physical sciences at the master's and bachelor's degree levels. Economies of scale may well be tied to this phenomenon, as doctorate-granting 
institutions in the Delaware Study tend to be large, high-volume student credit hour programs.

The second important issue clarified by this study is that within an academic discipline, there are clear and measurable variables that are associated with instructional expense. Brinkman (1990) postulated that the behavior of marginal and average costs can be associated with four dimensions that are subsequently measured in the Delaware Study. Those dimensions are size (i.e., quantity of activity or output), scope of services offered, level of instruction (for instructional costs), and discipline (for instructional costs). While Brinkman ascribed two of these dimensions specifically to instructional expenditures, all four, as discussed below, are applicable.

Economies of scale are very much in evidence in examining instructional expenditures across the disciplines among institutions participating in the Delaware Study. Student credit hour production, magnitude of faculty workload, and faculty size are the most important predictors of instructional costs. Where faculty size is held relatively constant, increasing student credit hour production substantially reduces instructional expense. A proxy variable, i.e., student credit hours taught per FTE faculty, arrives at the same conclusion: increase individual faculty workloads and costs are reduced.

The data also suggest that increasing faculty size is tied to increased instructional costs, even in instances where less well paid, nontenurable fulltime faculty and adjuncts are used to increase teaching activity. This finding is consistent with the manner in which costs track Carnegie institutional classification and highest degree offered in a program. In general, research and doctoral institutions tend to have the highest instructional expenditures, as do programs that offer the doctorate. Because research and public service activity are expected of faculty at research and doctoral institutions, and are components of any reputable doctoral program, it is reasonable to assume that faculty, particularly tenured and tenure track, in these institutions and programs will have research and public service obligations as part of their administered workload. Because they do things other than teach (i.e., increased scope of services offered), additional faculty must be secured to meet instructional demand, thereby increasing instructional costs. It is also noteworthy that in instances where the proportion of tenured and tenure-track faculty is higher, costs are higher.

Other variables are clearly tied to instructional costs, but less so than credit hour production, faculty workload, and faculty size. The presence of a graduate component in the department adds to instructional expenditures. This is not surprising; it is generally accepted that graduate education is more costly, given the small classes and high degree of individual instruction associated with graduate teaching. The relative contribution of this variable is small, compared with the three aforementioned variables. However, it is worth noting that over all three data collection cycles, departments offering the doctorate in biology, chemistry, physics, and philosophy increased costs by an average of 10 percent, while English departments offering the Ph.D. were, on average, 5 percent more expensive than non-doctorategranting departments.

\section{Discussion}

The data analyzed from three discrete cycles of the Delaware Study of Instructional Costs and Productivity lead to a number of clear and consistent conclusions with respect to direct instructional expenditures in higher education.

Foremost is that the disciplinary mix at an institution has a profound impact on the overall level of instructional expenditures at an institution. Analysis of three cycles of Delaware Study data consistently demonstrates that there are real and substantial differences between and across disciplines at an institution. With few exceptions, the differences between the disciplines appear to be more important than the Carnegie classification of an institution. Simply put, it is possible to examine two research universities, one with a heavy curricular emphasis on physical sciences and engineering, the other with emphasis on the social sciences and humanities, and find substantial differences between overall instructional costs at the two institutions owing to 
the disciplinary mix at each. Similarly, it is possible to examine a research university and a baccalaureate college, each focused on the social sciences and humanities, and find no difference in overall unit instructional costs, again owing to disciplinary mix.

Finding that most of the variation in instructional expenditures is associated with the mix of disciplines within an institution is important in light of the issues raised in the first part of the congressionally mandated study. Researchers found no apparent relationship between the level of instructional expenditures at an institution and the tuition rate charged by that institution. The findings from this analysis of direct instructional expense underscore the difficulty in relating price to cost at the level of the academic discipline. While direct instructional expense per student credit hour taught in civil engineering is three times more than that for sociology, it is not practical for an institution to charge engineering majors a tuition rate three times that charged to sociology majors. Indeed, researchers for the first report in the congressionally mandated study found that institutional tuition rates at public institutions are largely tied to state appropriation levels, while competitive market forces are associated with tuition levels at private institutions. Neither of these external factors has anything remotely to do with what it costs to deliver instruction in a discipline. Price and cost are not interchangeable constructs.

There are important factors that are associated with direct expense at the academic discipline level of analysis. Higher education is no different from any other enterprise with respect to economies of scale - the larger the volume of unit output from a fixed workforce, the lower the unit cost of production. Increasing the size of the workforce in any substantial way without concurrently adjusting productivity is tied to rises in costs. The scope of services offered by a department or program, i.e., the extent to which it moves beyond instruction into areas of research and public service, is tied to increases in direct instructional expense for that unit. And finally, the introduction of graduate education into a department, while not as important a predictor of cost as productivity and faculty size, nonetheless is associated with increased instructional costs of a unit. It must again be emphasized that these internal cost factors are very different from the external factors tied to price (i.e., state appropriations, market forces, etc.) These are noninterchangeable constructs for which no strong statistical relationship has been found. 


\section{References}

Boyer, E.L. (1990). Scholarship Reconsidered: Priorities of the Professoriate. Princeton, NJ: Carnegie Foundation for the Advancement of Teaching.

Boyer Commission on Educating Undergraduates in the Research University. (1998). Reinventing Undergraduate Education. Stony Brook, NY: State University of New York at Stony Brook.

Brinkman, P.T. (2000). The Economics of Higher Education: Focus on Cost. In M.F. Middaugh (Ed.), Analyzing Costs in Higher Education: What Institutional Researchers Need to Know, Vol. 106, New Directions for Institutional Research Monograph Series. San Francisco, CA: Jossey-Bass Publishers.

Brinkman, P.T. (1990). Higher Education Cost Functions. In S.A. Hoenack and E.L. Collins (Eds.), The Economics of American Universities: Management, Operations, and Fiscal Environments. Albany, NY: State University of New York Press.

Cunningham, A.F., Wellman, J.V., Clinedinst, M.E., and Merisotis, J.P. (2001). Study of College Costs and Prices, 1988-89 to 1997-98 (NCES 2002-157). U.S. Department of Education. Washington, D.C.: National Center for Education Statistics.

Hoenack, S.A. (1990). An Economist's Perspective on Costs Within Higher Education Institutions. In S.A. Hoenack and E.L Collins (Eds.), The Economics of American Universities: Management, Operations, and Fiscal Environment. Albany, NY: State University of New York Press.

Jones, D.P. (2000). An Alternative Look at the Cost Question. In Higher Education Cost Measurement: Public Policy Issues, Options, and Strategies. Washington, DC: The Institute for Higher Education Policy.

Middaugh, M.F. (1995-96). Closing in on Faculty Productivity Measures. In Planning for Higher Education, 24 (2): 1-12.

Middaugh, M.F. (1998-99). How Much Do Faculty Really Teach? In Planning for Higher Education, 27 (2): $1-11$.

Middaugh, M.F. (2001). Understanding Faculty Productivity: Standards and Benchmarks for Colleges and Universities. San Francisco, CA: Jossey-Bass Publishers.

National Commission on the Cost of Higher Education. (1998). Straight Talk About College Costs and Prices. Phoenix, AZ: The Oryx Press.

Research Associates of Washington. (Annually). Higher Education Revenues and Expenditures: Institutional Data. Washington, DC: Research Associates of Washington.

Taylor, B.E., and Massy, W.F. (1996). Strategic Indicators for Higher Education: Vital Benchmarks and Information to Help You Evaluate and Improve Your Institution's Performance. Princeton, NJ: Peterson Guides. 
U.S. Department of Education. (2000). Index of CIP-2000 Codes and Program Titles (NCES: 2002-165). Washington, DC: National Center for Education Statistics.

Zemsky, R., and Massy, W. (1990). Cost Containment: Committing to a New Economic Reality. Change 22 (6): 16-22. 
Appendix A

\section{Delaware Study Institutional Participant List}


A-2 
Appalachian State University

Arizona State University

Arizona State University - West

Arkansas State University

Asbury College

Auburn University - Main Campus

Auburn University - Montgomery

Augusta College

Averett College

Ball State University

Baylor University

Belmont University

Black Hills State University

Bloomsburg University of Pennsylvania

Blufton College

Boston University

Bowling Green State University

Bradley University

Bridgewater State College

Brigham Young University

Butler University

Caldwell College

California State University - Fresno

California State University - Long Beach

California State University - San Marcos

Carleton College

Catholic University of America

Centenary College of Louisiana

Central Connecticut State University

Central Michigan University

Charleston Southern University

Christopher Newport University

Clarion University

Clarkson University

Clemson University

Cleveland State University

Coastal Carolina University

College of Charleston

College of Mount St. Joseph

College of New Rochelle

College of St. Mary

College of St. Elizabeth

College of the Holy Cross

Creighton University

Daemen College

Dakota State University
Davidson College

Delta State University

De Paul University

De Pauw University

Drew University

Drexel University

Drury University

Duquesne University

East Carolina University

East Tennessee University

Eastern Mennonite University

Eastern Michigan University

Eastern New Mexico University

Eastern Washington University

Edinboro University of Pennsylvania

Elizabeth City State University

Fayetteville State University

Florida Institute of Technology

Florida International University

Florida State University

Furman University

George Washington University

Georgetown University

Georgia Institute of Technology

Georgia Southern University

Georgia State University

Georgian Court College

Gonzaga University

Goshen College

Grambling State University

Grand Valley State University

Grinnell College

Gwynedd-Mercy College

Hartwick College

Indiana State University

Indiana University-Purdue University at Indianapolis

Indiana University-South Bend

Indiana University

Iowa State University

Ithaca College

Jackson State University

Jacksonville State University

James Madison University

Kansas State University

Keene State College 
Kennesaw State College

Kent State University

La Salle University

Lake Superior State University

Lander University

Lebanon Valley College

Longwood College

Louisiana State University-Baton Rouge

Louisiana State University-Shreveport

Louisiana Tech University

Loyola Marymount University

Lynchburg College

Marist College

Marshall University

Marygrove College

Marywood University

McNeese State University

Mercer University

Mesa State College

Miami University

Michigan State University

Michigan Technological University

Millikin University

Mississippi State University

Mississippi University For Women

Mississippi Valley State University

Montana State University - Billings

Montana State University - Bozeman

Montclair State University

Moravian College

Mount Saint Mary's College (Maryland)

Muhlenberg College

Nazareth College of Rochester

New York State College of Ceramics

Niagara University

Nicholls State University

North Carolina A\&T State University

North Carolina Central University

North Carolina State University

North Dakota State University

Northeastern University

Northern Arizona University

Northern Illinois University

Northern Kentucky University

Northern State University

Northwestern State University of Louisiana

Oakland University

Oberlin College

Ohio Northern University

Ohio State University

Oklahoma City University
Oklahoma State University

Old Dominion University

Oregon State University

Pacific Lutheran University

Park University

Portland State University

Prairie View A \& M University

Presbyterian College

Purdue University Calumet

Radford University

Ramapo College of New Jersey

Rhode Island College

Rider University

Rockhurst University

Rollins College

Rowan University

Saint Edward's University

Saint Louis University

St. Michael's College

Saint Norbert College

St. Paul's College

Salisbury State University

Samford University

San Jose State University

Seattle University

Siena College

Slippery Rock University

Sonoma State University

South Dakota School of Mine \& Technology

South Dakota State University

Southeast Missouri State University

Southeastern Louisiana University

Southern Illinois University-Carbondale

Southern Methodist University

Southern University and A\&M College

Southern University - Baton Rouge

Southern Utah University

Southwest Missouri State University

Southwest Texas University

St. Bonaventure University

St. Mary's University

State University of West Georgia

SUNY-Albany

SUNY-Binghamton

SUNY-Brockport

SUNY-Cortland

SUNY-Geneseo

SUNY-Institute of Technology-Utica

SUNY-New Paltz

SUNY-Oneonta

SUNY-Oswego 
SUNY-Plattsburgh

SUNY-Potsdam

SUNY-Purchase College

SUNY-Stony Brook

SUNY - University at Buffalo

SUNY - College at Fredonia

Sweet Briar College

Taylor University - Fort Wayne

Taylor University - Upland

Teachers College at Columbia University

Temple University

Tennessee State University

Tennessee Technological University

Texas A \& M University-Main Campus

Texas Tech University

Towson State University

Trinity College

Troy State University

Tulane University

University of Akron

University of Alabama-Birmingham

University of Alabama-Huntsville

University of Alabama-Tuscaloosa

University of Alaska-Anchorage

University of Alaska - Fairbanks

University of Alaska-Southeast

University of Arizona

University of Arkansas-Little Rock

University of Arkansas-Fayetteville

University of California-Irvine

University of Central Florida

University of Charleston

University of Colorado-Boulder

University of Colorado at Colorado Springs

University of Colorado at Denver

University of Connecticut

University of Dallas

University of Dayton

University of Delaware

University of Florida

University of Georgia

University of Guam

University of Hartford

University of Hawaii at Manoa

University of Houston-Clear Lake

University of Houston-Main Campus

University of Houston-Victoria

University of Idaho

University of Iowa

University of Kansas

University of Louisiana at Lafayette
University of Louisiana at Monroe

University of Maine

University of Maine at Machias

University of Maryland - Baltimore County

University of Maryland-College Park

University of Massachusetts-Amherst

University of Miami

University of Minnesota-Duluth

University of Minnesota - Morris

University of Minnesota - Twin Cities

University of Mississippi

University of Missouri-Columbia

University of Missouri-Kansas City

University of Missouri-Rolla

University of Missouri-St. Louis

University of Montana

University of Montevallo

University of Nebraska-Kearney

University of Nebraska-Lincoln

University of Nevada-Las Vegas

University of New Hampshire

University of New Haven

University of New Orleans

University of North Carolina - Asheville

University of North Carolina-Chapel Hill

University of North Carolina-Charlotte

University of North Carolina-Greensboro

University of North Carolina-Pembroke

University of North Carolina-Wilmington

University of Northern Colorado

University of Northern Iowa

University of Notre Dame

University of Oklahoma

University of Oregon

University of Pittsburgh

University of Pittsburgh-Bradford

University of Scranton

University of South Alabama

University of South Carolina-Columbia

University of South Dakota

University of South Florida

University of Southern Indiana

University of Southern Mississippi

University of Tennessee-Chattanooga

University of Tennessee-Knoxville

University of Texas - Austin

University of Texas-Brownsville

University of Texas-El Paso

University of the Rio Grande-Ohio

University of Utah

University of Vermont 
University of Virginia-Charlottesville

University of Washington

University of West Alabama

University of West Florida

University of Wisconsin - Madison

University of Wisconsin-Milwaukee

University of Wisconsin-Whitewater

University of Wyoming

Utah State University

Virginia Commonwealth University

Virginia Polytechnic Institute and State University

Wake Forest University

Washburn University

Washington College
Webster University

West Chester University

West Virginia University

Western Carolina University

Western Kentucky University

Western Michigan University

Western Washington University

Wichita State University

Wilkes University

William Paterson University

Winston-Salem State University

Wright State University

Xavier University of Louisiana

Youngstown State University 
Appendix B

\section{Data Collection Form}


B-2 


\section{Data Collection Form}

2002-03 Delaware Study of Instructional Cost and Productivity

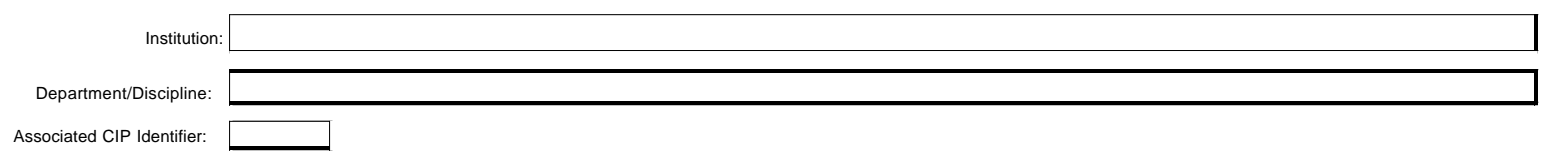

Please indicate the average number of degrees awarded in this discipline at each degree level over the three year period from 1998-99 through 2000-01.

Place an " $X$ " in the box below that

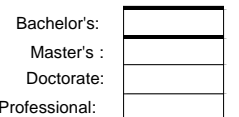

Place an ' $X$ ' in the box below if this discipline is

describes your academic calendar: non-degree granting.

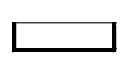

Semester

Quarter

\section{A. INSTRUCTIONAL COURSELOAD: FALL SEMESTER, 2001}

Please complete the following matrix, displaying student credit hours and organized class sections taught, by type of faculty, and by level of instruction. Be sure to consult definitions before proceeding. Do not input data in shaded cells except for those mentioned in the important note below that pertains to (G) and (J).

\begin{tabular}{|c|c|c|c|c|c|c|c|c|c|c|c|c|c|c|c|c|}
\hline \multicolumn{4}{|c|}{ Faculty } & \multicolumn{8}{|c|}{ Student Credit Hours } & \multicolumn{5}{|c|}{ Organized Class Sections } \\
\hline \multirow{2}{*}{ Classification } & \multicolumn{3}{|c|}{ FTE Faculty } & \multirow{2}{*}{$\begin{array}{c}\text { (D) } \\
\text { Lower Div. } \\
\mathrm{OC}^{* 1}\end{array}$} & \multirow{2}{*}{$\begin{array}{c}\text { (E) } \\
\text { Upper Div. } \\
\mathrm{OC}^{*} 1\end{array}$} & \multirow{2}{*}{$\begin{array}{c}\text { (F) } \\
\text { Undergrad } \\
\text { Indv. } \\
\text { Instruct. }\end{array}$} & \multirow{2}{*}{$\begin{array}{c}\text { (G) } \\
\text { Total } \\
\text { Undergrad } \\
\text { SCH }\end{array}$} & \multirow{2}{*}{$\begin{array}{l}\text { (H) } \\
\text { Grad. } \\
\mathrm{OC}^{* 1}\end{array}$} & \multirow{2}{*}{$\begin{array}{c}\text { (I) } \\
\text { Graduate } \\
\text { Indv. } \\
\text { Instruct. }\end{array}$} & \multirow{2}{*}{$\begin{array}{c}\text { (J) } \\
\text { Total } \\
\text { Graduate } \\
\text { SCH }\end{array}$} & \multirow{2}{*}{$\begin{array}{c}\text { (K) } \\
\text { Total } \\
\text { Student } \\
\text { Credit Hours }\end{array}$} & \multirow{2}{*}{$\begin{array}{c}\text { (L) } \\
\text { Lab/Dsc/ } \\
\text { Rec. } \\
\text { Sections }\end{array}$} & \multicolumn{3}{|c|}{$\begin{array}{c}\text { Other Section Types } \\
\text { (Lecture, Seminar, etc.) }\end{array}$} & \multirow[b]{2}{*}{$\begin{array}{c}(\mathrm{P}) \\
\text { Total }\end{array}$} \\
\hline & Total & $\begin{array}{r}\text { Separately } \\
\text { Budgeted } \\
\end{array}$ & $\begin{array}{r}\text { Instruc- } \\
\text { tional } \\
\end{array}$ & & & & & & & & & & $\begin{array}{c}\text { (M) } \\
\text { Lower Div. }\end{array}$ & $\begin{array}{c}\text { (N) } \\
\text { Upper Div. }\end{array}$ & $\begin{array}{c}(0) \\
\text { Graduate } \\
\end{array}$ & \\
\hline \multicolumn{17}{|l|}{$\begin{array}{l}\text { Regular faculty: } \\
\text {-Tenured/Tenure Eligible }\end{array}$} \\
\hline \multicolumn{17}{|l|}{ - Other Regular Faculty } \\
\hline \multicolumn{17}{|l|}{ Supplemental Faculty } \\
\hline \multicolumn{17}{|l|}{$\begin{array}{l}\text { Teaching Assistants: } \\
-\quad \text { Credit Bearing Courses }\end{array}$} \\
\hline - Non-Credit Bearing Activity & & NA & & NA & NA & NA & NA & NA & NA & NA & NA & & & & & \\
\hline TOTAL & & & & & & & & & & & & & & & & \\
\hline
\end{tabular}

\section{B. COST DATA: ACADEMIC AND FISCAL YEAR 2001-02}

1. In the boxes below, enter the total number of student credit hours that were generated during Academic Year 2001-02 during terms that were supported by the department's instructional budget. (NOTE: Semester calendar institutions will typically report fall and spring student credit hours; quarter calendar institutions will usually report fall, winter, and spring student credit hours.)

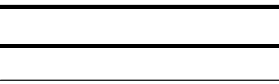

\section{A. Undergraduate}

B. Graduate

2. In the boxes below, enter totalire cexpenditures for instruction in FY 2001-02

\begin{tabular}{|c|c|c|}
\hline & A. Salaries & Are the benefits included in the number reported for salaries $(\mathrm{Y} \underline{\mathrm{N}})$ ? \\
\hline & B. Benefits & If the dollar value is not available, what percent of salary do benefits constitute at your institutipn? \\
\hline & C. Other than personnel expenditures. & \\
\hline & D. Total & \\
\hline
\end{tabular}

3. In the box below, enter totelirecexpenditures for separately budgeted research activity in FY 2001-02

4. In the box below, enter totalire cexpenditures for separately budgeted public service activity in FY 2001-02

${ }^{\mathrm{I}} \mathrm{OC}=$ organized classes

${ }^{2}$ Summer semesters and quarters are not generally supported by the department's instructional budget. 
B-4 
Appendix C

Glossary 


$$
\text { C-2 }
$$




\section{Glossary}

\section{Institution Type}

The Delaware Study collects data on teaching loads, instructional costs, and externally funded scholarly activity from public and private 4-year institutions throughout the United States. Data are collected using the template in appendix B. The data from these colleges and universities are analyzed within the framework of the 1995 Carnegie Classification of Institutions of Higher Education. The institution types are as follows:

- Research Universities: Includes Research I and Research II institutions. The minimum criteria for inclusion in the research university category are a full range of baccalaureate programs, commitment to graduate education through the doctorate, and a high priority given to research. They award 50 or more doctoral degrees each year. In addition, they receive at least $\$ 15.5$ million in federal support.

- Doctoral Universities: Includes Doctoral I and Doctoral II institutions. The minimum criteria for inclusion in the doctoral university category are a full range of baccalaureate programs, and a commitment to graduate education through the doctorate. They award annually at least 10 doctorates in 3 or more disciplines, or 20 or more doctoral degrees in 1 or more disciplines.

- Comprehensive Colleges and Universities: Includes Comprehensive I and Comprehensive II institutions. The minimum criteria for inclusion in comprehensive college and university category are a full range of baccalaureate programs, and a commitment to graduate education through the master's degree. They award 20 or more master's degrees in 1 or more disciplines.

- Baccalaureate Colleges: Includes Baccalaureate I and Baccalaureate II institutions. The minimum criteria for inclusion in the baccalaureate college category are that they award less than 40 percent of their baccalaureate degrees in liberal arts fields.

\section{Academic Department/Discipline}

The disciplines selected for benchmarking in the Delaware Study are found in the Classification of Instructional Programs Taxonomy, developed by the National Center for Education Statistics. The data are typically benchmarked at the four-digit CIP code level. Specifically, the Delaware Study examines discrete disciplines within a broad curricular field. For example, in Engineering (CIP code 14.XX), data are collected for those engineering disciplines at a given institution, e.g., 14.03 (Agricultural Engineering), 14.07 (Chemical Engineering), 14.08 (Civil Engineering), 14.10 (Electrical Engineering), 14.19 (Mechanical Engineering), and so on. Institutions with different engineering departments would report data for the appropriate four-digit CIP code. The pattern would be repeated across other curricular areas, e.g., Education (CIP code 13.XX), Physical Sciences (CIP code 40.XX), Social Sciences (CIP code 45.XX), Visual and Performing Arts (CIP code 50.XX), Business Management (CIP code 52.XX), etc.

\section{Faculty}

The Delaware Study collects detailed data on teaching loads, arrayed by category of faculty. Four discrete categories are examined:

- Tenured and Tenure-track Faculty: Those individuals who either hold tenure at the institution, or for whom tenure is an expected outcome.

- Nontenure-track Faculty: Those individuals who teach on a recurring contractual basis at the institution, but whose academic title or budget line render them ineligible for academic tenure. 
- Supplemental Faculty: Supplemental faculty are characteristically paid from a pool of temporary funds. Their appointment is nonrecurring, although the same individual might receive a temporary appointment in successive terms. The key point is that funding is temporary, and there is no expectation of continuing appointment. This category includes adjunct faculty, administrators or professional personnel at the institution who teach but whose primary job responsibility is nonfaculty, contributed service personnel, etc.

- Graduate Teaching Assistants: Teaching assistants are those students at the institution who receive a stipend strictly for teaching activity. Includes teaching assistants who are instructors of record, but also includes teaching assistants who function as discussion or recitation section leaders, laboratory section leaders, and other types of organized class sections in which instruction takes place, but which may not carry credit and for which there is no formal instructor of record. Graduate research assistants are not included in this category.

\section{Faculty Full-Time Equivalency (FTE)}

The Delaware Study develops benchmark data for teaching loads (student credit hours taught per FTE faculty, FTE students taught per FTE faculty) and cost measures (direct research expenditures per FTE faculty). In converting full- and part-time faculty to FTE faculty, the following conventions are used:

- Tenured/Tenure-track and Nontenure-track Faculty: The definition of full-time equivalency begins with the total FTE value for filled faculty positions as they appear in the fall personnel file at an institution. A fulltime faculty member is 1.0 FTE. An individual who works three-quarters time and is paid accordingly is 0.75 FTE. Filled positions are those that have salaries associated with them. This includes paid leaves such as sabbaticals wherein the individual is receiving a salary, but excludes unpaid leaves of absence. Institutions are asked to subtract from the total FTE those portions of faculty time that are externally funded and contractually obligated for activity other than teaching, e.g., research or service. The remainder is instructional FTE, the value used in teaching load benchmarks. For example, suppose Professor Jones is a fulltime member of the Chemistry faculty. He would initially be reported as 1.0 FTE. Professor Jones has a research grant that contractually obligates him to spend one-third of his time in research. The externally supported portion of his position is $0.33 \mathrm{FTE}$, which would be subtracted from the total FTE. As a result, 0.66 FTE is the instructional portion of Professor Jones' full-time equivalency that is used in developing Delaware Study teaching load benchmarks.

- Supplemental Faculty: Full-time equivalency for supplemental faculty is calculated by taking the total teaching credit hours (which are generally equivalent to the credit value of the course(s) taught) for each supplemental faculty, and dividing by 12 . Twelve hours is a broadly accepted standard for a full-time teaching load.

- Teaching Assistants: Full-time equivalency for teaching assistants is either defined as the value for the budget line on the institution's personnel file, or is calculated using the same convention as with supplemental faculty.

\section{Faculty Teaching Load}

Teaching loads are measured in terms of student credit hours and organized class sections taught in both regularly scheduled and individualized instruction courses. Courses are arrayed by lower division and upper division levels within undergraduate instruction, and by graduate level.

- Course: An instructional activity, identified by academic discipline and number, in which 
students enroll, typically to earn academic credit applicable to a degree objective. Excludes noncredit courses, but includes zero credit course sections which are requirements of or prerequisites to degree programs, and that are scheduled, and consume institutional or departmental resources in the same manner as credit courses. Zero-credit course sections are typically supplements to the credit-bearing lecture portion of a course. Zero-credit sections are frequently listed as laboratory, discussion, or recitation sections in conjunction with the credit-bearing lecture portion of a course.

- Organized Class Course: A course that is provided principally by means of regularly scheduled classes meeting in classrooms or similar facilities at stated times.

- Individual Instruction Course: A course in which instruction is not conducted in regularly scheduled class meetings. Includes readings or special topics courses, problems or research courses, including dissertation/thesis research, and individual lesson courses (typically in music and fine arts).

- Course Section: A unique group of students that meets with one or more instructors.

- Course Credit: The academic credit value of a course; the value recorded for a student who successfully completes the course.

- Lower Division Instruction: Courses typically associated with the first and second year of college study.

- Upper Division Instruction: Courses typically associated with the third and fourth year of college study.

- Graduate Level Instruction: Courses typically associated with post-baccalaureate study.

- Student Credit Hours: The credit value of a course (typically three or four credits) multiplied by the enrollment in the course.

\section{Fiscal Data}

The Delaware Study collects total direct expenditure data in certain functional areas, i.e., instruction, research, and public service. Direct expenditure data reflect costs incurred for personnel compensation, supplies, and services used in the conduct of each of these functional areas. They include acquisition costs of capital assets such as equipment and library books to the extent that funds are budgeted for and used by operating departments for instruction, research, and public service. In developing the cost models used in this study, direct expenditures for instruction are the focus of analysis. It is therefore important to have a clear understanding of what is meant by "instruction," and the components that constitute instructional expenditures.

The instruction function, for purposes of this study, includes general academic instruction, occupational and vocational instruction, community education, preparatory and adult basic education, and remedial and tutorial instruction conducted by the teaching faculty for the institution's students. Departmental research and service that are not separately budgeted are included under instruction. In other words, research that is externally funded is excluded from instructional expenditures, as are any departmental funds that are expended for the purpose of matching external research funds as part of a contractual or grant obligation. Also excluded are expenditures for academic administration where the primary function is administration. For example, deans would be excluded, but department chairs, whose primary function is instructional support, would be included.

Direct instructional expenditures are disaggregated into three categories:

1. Salaries: All wages paid to support the instructional function in a given department or program during the fiscal year. While these will largely be faculty salaries, they also include those for clerical (e.g., department secretary), professional (e.g., lab technicians), graduate student (stipends but not tuition waivers), and any other 
personnel who support the teaching function and whose salaries and wages are paid from the department's/program's instructional budget.

2. Benefits: Expenditures for benefits associated with the personnel for whom salaries and wages were reported on the previous entry. Institutions that book benefits centrally are asked to provide, in concert with their business office, a reasonable estimate for departmental benefits. Where that cannot be done, the University of Delaware imputes a cost factor based upon the current benefit rate for the institution, as published in the annual salary issue of Academe. If no rate is available, a default value of 28 percent is used.

3. Other Than Personnel Costs: This category includes nonpersonnel items such as travel, supplies and expense, noncapital equipment purchases, etc., that are typically part of a department or program's cost of doing business. Excluded from this category are items such as central computing costs, centrally allocated computing labs, graduate student tuition remission and fee waivers, etc. 
Appendix D

\section{Tables}

D-1 
D-2 


\section{Table of Contents}

D-1 Nonresponse bias for 2001 Delaware Study, by institution's Carnegie

classification

D-2 Nonresponse bias for 2000 Delaware Study, by institution's Carnegie

classification

D-3 Nonresponse bias for 1999 Delaware Study, by institution's Carnegie

classification

D-4 Nonresponse bias for 1998 Delaware Study, by institution's Carnegie classification

D-5 Nonresponse bias for 1997 Delaware Study, by institution's Carnegie classification

D-6 Summary of ANOVA to test for differences in average cost of instruction, by discipline and Carnegie classification, by highest degree offered, and undergraduate/graduate program mix in discipline: 2001, 2000, and 1998 Delaware Study

D-7 Pairwise multiple comparison of cost of instruction by discipline within Carnegie classification based on the Bonferroni procedure at the 5 percent level of significance: 2001 Delaware Study

D-8 Pairwise multiple comparison of cost of instruction by discipline within Carnegie classification based on the Bonferroni procedure at the 5 percent level of significance: 2000 Delaware Study

D-9 Pairwise multiple comparison of cost of instruction by discipline within Carnegie classification based on the Bonferroni procedure at the 5 percent level of significance: 1998 Delaware Study

D-10 Pairwise multiple comparison of cost of instruction by discipline within highest degree offered based on the Bonferroni procedure at the 5 percent level of significance: 2001 Delaware Study

D-11 Pairwise multiple comparison of cost of instruction by discipline within highest degree offered based on the Bonferroni procedure at the 5 percent level of significance: 2000 Delaware Study

D-12 Pairwise multiple comparison of cost of instruction by discipline within highest degree offered based on the Bonferroni procedure at the 5 percent level of significance: 1998 Delaware Study 


\section{Table of Contents-Continued}

D-13 Pairwise multiple comparison of cost of instruction by discipline within undergraduate/graduate program mix based on the Bonferroni procedure at the 5 percent level of significance: 2001 Delaware Study

D-14 Pairwise multiple comparison of cost of instruction by discipline within undergraduate/graduate program mix based on the Bonferroni procedure at the 5 percent level of significance: 2000 Delaware Study

D-15 Pairwise multiple comparison of cost of instruction by discipline within undergraduate/graduate program mix based on the Bonferroni procedure at the 5 percent level of significance: 1998 Delaware Study

D-16 Summary of determinants of direct instructional cost per student credit hour taught, by discipline: 2001 Delaware Study

D-17 Summary of determinants of direct instructional cost per student credit hour taught, by discipline: 2000 Delaware Study

D-18 Summary of determinants of direct instructional cost per student credit hour taught, by discipline: 1998 Delaware Study 
Table D-1. Nonresponse bias for 2001 Delaware Study, by institution's Carnegie classification

\begin{tabular}{|c|c|c|c|c|c|c|c|}
\hline \multirow{2}{*}{$\begin{array}{l}\text { Carnegie classification and } \\
\text { institutional characteristic }\end{array}$} & \multicolumn{2}{|c|}{ Participants } & \multicolumn{2}{|c|}{ Nonparticipants } & \multirow[b]{2}{*}{$\begin{array}{r}\text { Difference } \\
\left(Y_{1}-Y_{2}\right) \\
\end{array}$} & \multirow{2}{*}{$\begin{array}{c}\text { Magni- } \\
\text { tude of } \\
\text { bias }^{1}\end{array}$} & \multirow[b]{2}{*}{$\begin{array}{r}\text { Percent } \\
\text { difference }\end{array}$} \\
\hline & $\mathrm{N}_{1}$ & $\operatorname{Avg}\left(Y_{1}\right)$ & $\mathrm{N}_{2}$ & $\operatorname{Avg}\left(Y_{2}\right)$ & & & \\
\hline \multicolumn{8}{|l|}{ Research } \\
\hline 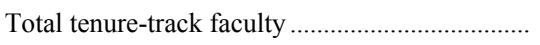 & 46 & 688 & 80 & 626 & 61 & 39 & 8.9 \\
\hline 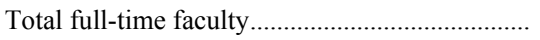 & 46 & 1,008 & 80 & 944 & 65 & 41 & 6.4 \\
\hline $\begin{array}{l}\text { Tenure-track faculty as percent of total full- } \\
\text { time faculty }\end{array}$ & 46 & 68 & 80 & 66 & 2 & 1 & 2.2 \\
\hline Total full-time-equivalent (FTE) enrollment...... & 46 & 20,877 & 80 & 17,465 & 3,412 & 2,167 & 16.3 \\
\hline Undergraduate enrollment as percent of total .... & 46 & 78 & 80 & 68 & 10 & 6 & 12.8 \\
\hline FTE enrollment per full-time faculty ....................... & 46 & 21 & 80 & 18 & 3 & 2 & 12.4 \\
\hline Bachelor's degrees awarded as percent of & 46 & 66 & 80 & 58 & 8 & 5 & 12.5 \\
\hline Master's degrees awarded as percent of total..... & 46 & 24 & 80 & 28 & -4 & -3 & -16.6 \\
\hline Doctor's degrees awarded as percent of total..... & 46 & 10 & 80 & 14 & -4 & -3 & -44.9 \\
\hline Instructional expenditure per FTE enrollment ... & 42 & 7,230 & 43 & 8,700 & $-1,470$ & -744 & -20.3 \\
\hline 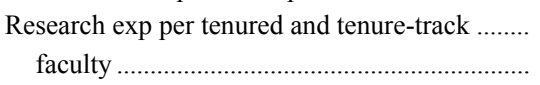 & 42 & 136,842 & 43 & 189,807 & $-52,965$ & $-26,794$ & -38.7 \\
\hline $\begin{array}{l}\text { Public service exp per tenured and tenure- } \\
\text { track faculty }\end{array}$ & 42 & 53,559 & 43 & 54,554 & -995 & -503 & -1.9 \\
\hline 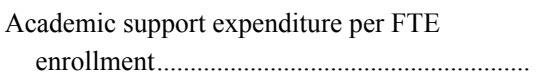 & 42 & 1,807 & 43 & 3,458 & $-1,651$ & -835 & -91.4 \\
\hline Average scholarship per FTE enrollment............ & 42 & 1,504 & 43 & 1,771 & -267 & -135 & -17.8 \\
\hline Library expenditure per FTE enrollment.............. & 42 & 605 & 43 & 699 & -94 & -47 & -15.5 \\
\hline \multicolumn{8}{|l|}{ Doctoral } \\
\hline 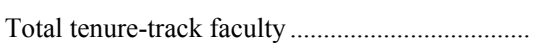 & 33 & 310 & 77 & 254 & 56 & 39 & 18.0 \\
\hline 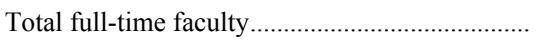 & 33 & 500 & 77 & 412 & 88 & 61 & 17.5 \\
\hline 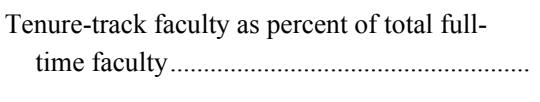 & 33 & 63 & 77 & 60 & 3 & 2 & 4.7 \\
\hline Total full-time-equivalent (FTE) enrollment...... & 33 & 11,033 & 77 & 8,391 & 2,642 & 1,849 & 23.9 \\
\hline Undergraduate enrollment as percent of total .... & 33 & 82 & 77 & 69 & 14 & 9 & 16.4 \\
\hline FTE enrollment per full-time faculty ...................... & 33 & 22 & 77 & 20 & 2 & 1 & 7.3 \\
\hline $\begin{array}{l}\text { Bachelor's degrees awarded as percent of } \\
\text { total }\end{array}$ & 33 & 68 & 77 & 56 & 12 & 9 & 18.1 \\
\hline Master's degrees awarded as percent of total..... & 33 & 27 & 77 & 33 & -6 & -4 & -22.7 \\
\hline Doctor's degrees awarded as percent of total..... & 33 & 5 & 77 & 11 & -6 & -4 & -130.2 \\
\hline $\begin{array}{l}\text { Instructional expenditure per FTE enrollment ... } \\
\text { Research exp per tenured and tenure-track }\end{array}$ & 28 & 5,152 & 36 & 5,981 & -829 & -466 & -16.1 \\
\hline 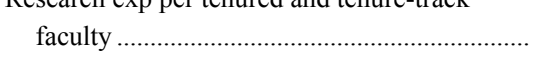 & 28 & 46,500 & 36 & 62,394 & $-15,894$ & $-8,940$ & -34.2 \\
\hline $\begin{array}{l}\text { Public service exp per tenured and tenure- } \\
\text { track faculty }\end{array}$ & 28 & 22,829 & 36 & 20,376 & 2,452 & 1,379 & 10.7 \\
\hline Academic support expenditure per FTE & & & & & & & \\
\hline 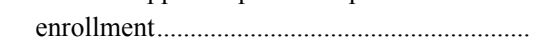 & 28 & 1,401 & 36 & 1,430 & -29 & -16 & -2.1 \\
\hline Average scholarship per FTE enrollment............. & 28 & 1,292 & 36 & 1,253 & 39 & 22 & 3.0 \\
\hline Library expenditure per FTE enrollment............. & 28 & 506 & 36 & 475 & 31 & 17 & 6.1 \\
\hline
\end{tabular}

See notes at the end of the table. 
Table D-1. Nonresponse bias for 2001 Delaware Study, by institution's Carnegie classification-Continued

\begin{tabular}{|c|c|c|c|c|c|c|c|}
\hline \multirow{2}{*}{$\begin{array}{l}\text { Carnegie classification and } \\
\text { institutional characteristic }\end{array}$} & \multicolumn{2}{|c|}{ Participants } & \multicolumn{2}{|c|}{ Nonparticipants } & \multirow{2}{*}{$\begin{array}{r}\text { Difference } \\
\left(\mathrm{Y}_{1}-\mathrm{Y}_{2}\right)\end{array}$} & \multirow{2}{*}{$\begin{array}{l}\text { Magni- } \\
\text { tude of } \\
\text { bias }^{1}\end{array}$} & \multirow{2}{*}{$\begin{array}{r}\text { Percent } \\
\text { difference }\end{array}$} \\
\hline & $\mathrm{N}_{1}$ & $\operatorname{Avg}\left(\mathrm{Y}_{1}\right)$ & $\mathrm{N}_{2}$ & $\operatorname{Avg}\left(\mathrm{Y}_{2}\right)$ & & & \\
\hline \multicolumn{8}{|l|}{ Comprehensive } \\
\hline 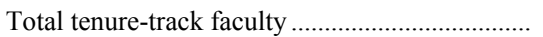 & 72 & 176 & 457 & 122 & 53 & 46 & 30.3 \\
\hline 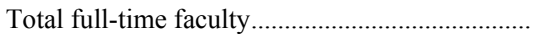 & 72 & 291 & 459 & 200 & 91 & 79 & 31.2 \\
\hline 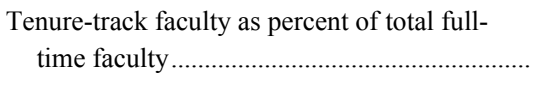 & 72 & 59 & 458 & 55 & 5 & 4 & 8.0 \\
\hline Total full-time-equivalent (FTE) enrollment...... & 72 & 6,257 & 459 & 4,454 & 1,803 & 1,559 & 28.8 \\
\hline Undergraduate enrollment as percent of total .... & 72 & 86 & 459 & 84 & 2 & 1 & 2.0 \\
\hline FTE enrollment per full-time faculty .................... & 72 & 23 & 457 & 25 & -2 & -1 & -7.1 \\
\hline \multicolumn{8}{|l|}{ Bachelor's degrees awarded as percent of } \\
\hline Master's degrees awarded as percent of total..... & 72 & 23 & 459 & 27 & -3 & -3 & -13.8 \\
\hline Doctor's degrees awarded as percent of total..... & 72 & 2 & 459 & 2 & 0 & 0 & 6.4 \\
\hline $\begin{array}{l}\text { Instructional expenditure per FTE enrollment ... } \\
\text { Research exp per tenured and tenure-track }\end{array}$ & 54 & 4,420 & 221 & 4,357 & 63 & 51 & 1.4 \\
\hline 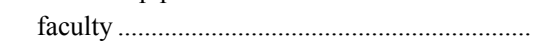 & 54 & 11,893 & 220 & 11,974 & -81 & -65 & -0.7 \\
\hline $\begin{array}{l}\text { Public service exp per tenured and tenure- } \\
\quad \text { track faculty }\end{array}$ & 54 & 12,876 & 220 & 13,721 & -845 & -679 & -6.6 \\
\hline Academic support expenditure per FTE & & & & & & & \\
\hline 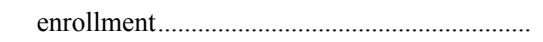 & 54 & 1,060 & 221 & 977 & 82 & 66 & 7.8 \\
\hline Average scholarship per FTE enrollment............ & 54 & 1,279 & 221 & 1,286 & -7 & -6 & -0.6 \\
\hline Library expenditure per FTE enrollment.............. & 54 & 354 & 221 & 363 & -9 & -7 & -2.6 \\
\hline \multicolumn{8}{|l|}{ Baccalaureate } \\
\hline 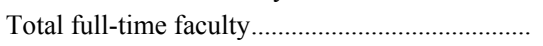 & 19 & 111 & 606 & 77 & 34 & 33 & 30.8 \\
\hline 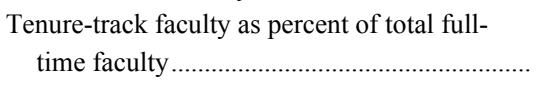 & 19 & 53 & 603 & 48 & 5 & 5 & 9.8 \\
\hline Total full-time-equivalent (FTE) enrollment...... & 19 & 1,898 & 612 & 1,453 & 446 & 432 & 23.5 \\
\hline Undergraduate enrollment as percent of total .... & 19 & 96 & 612 & 96 & 0 & 0 & -0.3 \\
\hline FTE enrollment per full-time faculty ..................... & 19 & 18 & 602 & 20 & -3 & -3 & -15.9 \\
\hline $\begin{array}{l}\text { Bachelor's degrees awarded as percent of } \\
\text { total }\end{array}$ & 19 & 96 & 607 & 94 & 2 & 2 & 2.1 \\
\hline Master's degrees awarded as percent of total..... & 19 & 2 & 607 & 5 & -4 & -4 & -240.1 \\
\hline $\begin{array}{l}\text { Instructional expenditure per FTE enrollment ... } \\
\text { Research exp per tenured and tenure-track }\end{array}$ & 7 & 4,126 & 76 & 3,759 & 366 & 335 & 8.9 \\
\hline 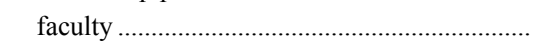 & 7 & 6,076 & 74 & 6,918 & -842 & -769 & -13.9 \\
\hline $\begin{array}{l}\text { Public service exp per tenured and tenure- } \\
\quad \text { track faculty }\end{array}$ & 7 & 18,487 & 74 & 15,560 & 2,928 & 2,675 & 15.8 \\
\hline Academic support expenditure per FTE & & & & & & & \\
\hline 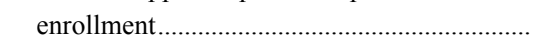 & 7 & 1,014 & 76 & 888 & 126 & 115 & 12.4 \\
\hline Average scholarship per FTE enrollment ............ & 7 & 1,529 & 76 & 1,528 & 1 & 1 & 0.1 \\
\hline Library expenditure per FTE enrollment............. & 7 & 418 & 76 & 322 & 96 & 88 & 23.1 \\
\hline
\end{tabular}

${ }^{1}$ Calculated as $\left(\mathrm{Y}_{1}-\mathrm{Y}_{2}\right) *\left(\mathrm{~N}_{2} /\left(\mathrm{N}_{1}+\mathrm{N}_{2}\right)\right)$.

SOURCE: University of Delaware, The Delaware Study of Instructional Costs and Productivity, 1997-2001; U.S. Department of Education, National Center for Education Statistics, Integrated Postsecondary Education Data System (IPEDS), Institutional Characteristics Surveys, 1997-2001. 
Table D-2. Nonresponse bias for 2000 Delaware Study, by institution's Carnegie classification

\begin{tabular}{|c|c|c|c|c|c|c|c|}
\hline \multirow{2}{*}{$\begin{array}{l}\text { Carnegie classification and } \\
\text { institutional characteristic }\end{array}$} & \multicolumn{2}{|c|}{ Participants } & \multicolumn{2}{|c|}{ Nonparticipants } & \multirow{2}{*}{$\begin{array}{l}\text { Difference } \\
\left(\mathrm{Y}_{1}-\mathrm{Y}_{2}\right)\end{array}$} & \multirow{2}{*}{$\begin{array}{l}\text { Magni- } \\
\text { tude of } \\
\text { bias }^{1}\end{array}$} & \multirow{2}{*}{$\begin{array}{l}\text { Percent } \\
\text { difference }\end{array}$} \\
\hline & $\mathrm{N}_{1}$ & $\operatorname{Avg}\left(\mathrm{Y}_{1}\right)$ & $\mathrm{N}_{2}$ & $\operatorname{Avg}\left(\mathrm{Y}_{2}\right)$ & & & \\
\hline \multicolumn{8}{|l|}{ Research } \\
\hline Total tenure-track faculty ......................................... & 48 & 697 & 78 & 619 & 78 & 48 & 11.2 \\
\hline Total full-time faculty ............................................... & 48 & 1,029 & 78 & 929 & 100 & 62 & 9.7 \\
\hline $\begin{array}{l}\text { Tenure-track faculty as percent of total full- } \\
\text { time faculty }\end{array}$ & 48 & 67 & 78 & 67 & 0 & 0 & 0.5 \\
\hline Total full-time-equivalent (FTE) enrollment...... & 48 & 21,657 & 78 & 16,898 & 4,759 & 2,946 & 22.0 \\
\hline Undergraduate enrollment as percent of total .... & 48 & 79 & 78 & 68 & 11 & 7 & 13.8 \\
\hline FTE enrollment per full-time faculty ....................... & 48 & 21 & 78 & 18 & 3 & 2 & 14.6 \\
\hline $\begin{array}{l}\text { Bachelor's degrees awarded as percent of } \\
\text { total }\end{array}$ & 48 & 66 & 78 & 58 & 9 & 5 & 13.2 \\
\hline Master's degrees awarded as percent of total..... & 48 & 24 & 78 & 29 & -5 & -3 & -19.5 \\
\hline Doctor's degrees awarded as percent of total..... & 48 & 10 & 78 & 14 & -4 & -3 & -42.8 \\
\hline Instructional expenditure per FTE enrollment ... & 43 & 7,123 & 42 & 8,845 & $-1,722$ & -851 & -24.2 \\
\hline $\begin{array}{l}\text { Research exp per tenured and tenure-track } \\
\text { faculty }\end{array}$ & 43 & 139,892 & 42 & 187,945 & $-48,053$ & $-23,744$ & -34.3 \\
\hline $\begin{array}{l}\text { Public service exp per tenured and tenure- } \\
\text { track faculty }\end{array}$ & 43 & 55,552 & 42 & 52,538 & 3,014 & 1,489 & 5.4 \\
\hline $\begin{array}{l}\text { Academic support expenditure per FTE } \\
\text { enrollment }\end{array}$ & 43 & 1,784 & 42 & 3,521 & $-1,737$ & -858 & -97.4 \\
\hline Average scholarship per FTE enrollment............. & 43 & 1,484 & 42 & 1,798 & -314 & -155 & -21.1 \\
\hline Library expenditure per FTE enrollment ................ & 43 & 591 & 42 & 715 & -124 & -61 & -20.9 \\
\hline \multicolumn{8}{|l|}{ Doctoral } \\
\hline 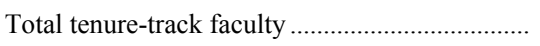 & 26 & 306 & 84 & 260 & 46 & 35 & 15.0 \\
\hline 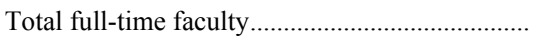 & 26 & 494 & 84 & 421 & 72 & 55 & 14.7 \\
\hline 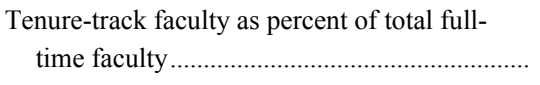 & 26 & 63 & 84 & 60 & 3 & 2 & 4.4 \\
\hline Total full-time-equivalent (FTE) enrollment....... & 26 & 10,917 & 84 & 8,647 & 2,270 & 1,734 & 20.8 \\
\hline Undergraduate enrollment as percent of total .... & 26 & 82 & 84 & 70 & 12 & 9 & 14.8 \\
\hline FTE enrollment per full-time faculty ..................... & 26 & 22 & 84 & 20 & 1 & 1 & 5.7 \\
\hline Bachelor's degrees awarded as percent of & 26 & 68 & 84 & 57 & 11 & 8 & 16.4 \\
\hline Master's degrees awarded as percent of total..... & 26 & 26 & 84 & 33 & -7 & -5 & -26.2 \\
\hline Doctor's degrees awarded as percent of total..... & 26 & 6 & 84 & 10 & -4 & -3 & -72.7 \\
\hline $\begin{array}{l}\text { Instructional expenditure per FTE enrollment ... } \\
\text { Research exp per tenured and tenure-track }\end{array}$ & 23 & 5,655 & 41 & 5,598 & 58 & 37 & 1.0 \\
\hline 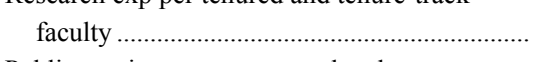 & 23 & 64,282 & 41 & 50,481 & 13,802 & 8,842 & 21.5 \\
\hline $\begin{array}{l}\text { Public service exp per tenured and tenure- } \\
\text { track faculty }\end{array}$ & 23 & 26,859 & 41 & 18,414 & 8,445 & 5,410 & 31.4 \\
\hline Academic support expenditure per FTE & 23 & 1,527 & 41 & 1,356 & 170 & 109 & 11.2 \\
\hline Average scholarship per FTE enrollment............. & 23 & 1,331 & 41 & 1,236 & 95 & 61 & 7.1 \\
\hline Library expenditure per FTE enrollment.............. & 23 & 553 & 41 & 452 & 100 & 64 & 18.1 \\
\hline
\end{tabular}

See notes at the end of the table. 
Table D-2. Nonresponse bias for 2000 Delaware Study, by institution's Carnegie classification-Continued

\begin{tabular}{|c|c|c|c|c|c|c|c|}
\hline \multirow{2}{*}{$\begin{array}{l}\text { Carnegie classification and } \\
\text { institutional characteristic }\end{array}$} & \multicolumn{2}{|c|}{ Participants } & \multicolumn{2}{|c|}{ Nonparticipants } & \multirow{2}{*}{$\begin{array}{r}\text { Difference } \\
\left(\mathrm{Y}_{1}-\mathrm{Y}_{2}\right)\end{array}$} & \multirow{2}{*}{$\begin{array}{l}\text { Magni- } \\
\text { tude of } \\
\text { bias }^{1}\end{array}$} & \multirow{2}{*}{$\begin{array}{r}\text { Percent } \\
\text { difference }\end{array}$} \\
\hline & $\mathrm{N}_{1}$ & $\operatorname{Avg}\left(\mathrm{Y}_{1}\right)$ & $\mathrm{N}_{2}$ & $\operatorname{Avg}\left(\mathrm{Y}_{2}\right)$ & & & \\
\hline \multicolumn{8}{|l|}{ Comprehensive } \\
\hline 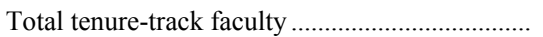 & 66 & 185 & 463 & 122 & 63 & 55 & 34.2 \\
\hline 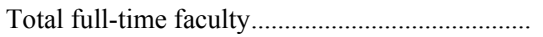 & 66 & 304 & 465 & 200 & 105 & 92 & 34.4 \\
\hline 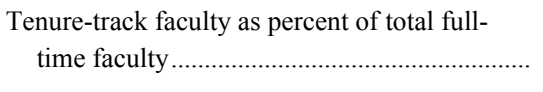 & 66 & 59 & 464 & 55 & 5 & 4 & 8.0 \\
\hline Total full-time-equivalent (FTE) enrollment...... & 66 & 6,691 & 465 & 4,416 & 2,275 & 1,992 & 34.0 \\
\hline Undergraduate enrollment as percent of total .... & 66 & 88 & 465 & 84 & 4 & 3 & 4.3 \\
\hline FTE enrollment per full-time faculty .................... & 66 & 22 & 463 & 25 & -3 & -3 & -13.6 \\
\hline \multicolumn{7}{|l|}{ Bachelor's degrees awarded as percent of } & 5.4 \\
\hline Master's degrees awarded as percent of total..... & 66 & 23 & 465 & 27 & -3 & -3 & -14.9 \\
\hline Doctor's degrees awarded as percent of total..... & 66 & 1 & 465 & 2 & -1 & -1 & -60.0 \\
\hline $\begin{array}{l}\text { Instructional expenditure per FTE enrollment ... } \\
\text { Research exp per tenured and tenure-track }\end{array}$ & 57 & 4,462 & 218 & 4,345 & 116 & 92 & 2.6 \\
\hline 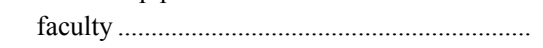 & 57 & 14,951 & 217 & 11,171 & 3,780 & 2,994 & 25.3 \\
\hline $\begin{array}{l}\text { Public service exp per tenured and tenure- } \\
\quad \text { track faculty }\end{array}$ & 57 & 16,416 & 217 & 12,803 & 3,613 & 2,861 & 22.0 \\
\hline Academic support expenditure per FTE & & & & & & & \\
\hline 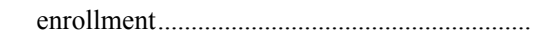 & 57 & 1,047 & 218 & 979 & 67 & 53 & 6.4 \\
\hline Average scholarship per FTE enrollment............ & 57 & 1,145 & 218 & 1,321 & -176 & -139 & -15.3 \\
\hline Library expenditure per FTE enrollment.............. & 57 & 383 & 218 & 356 & 27 & 21 & 7.0 \\
\hline \multicolumn{8}{|l|}{ Baccalaureate } \\
\hline Total full-time faculty............................................. & 14 & 100 & 611 & 77 & 23 & 23 & 23.1 \\
\hline $\begin{array}{l}\text { Tenure-track faculty as percent of total full- } \\
\text { time faculty }\end{array}$ & 14 & 51 & 608 & 48 & 3 & 3 & 5.5 \\
\hline Total full-time-equivalent (FTE) enrollment...... & 14 & 1,933 & 617 & 1,456 & 478 & 467 & 24.7 \\
\hline Undergraduate enrollment as percent of total .... & 14 & 97 & 617 & 96 & 1 & 1 & 1.4 \\
\hline FTE enrollment per full-time faculty ..................... & 14 & 19 & 607 & 20 & -1 & -1 & -5.5 \\
\hline Bachelor's degrees awarded as percent of & 14 & 98 & 612 & 94 & 4 & 4 & 4.4 \\
\hline Master's degrees awarded as percent of total..... & 14 & 2 & 612 & 5 & -3 & -3 & -185.3 \\
\hline $\begin{array}{l}\text { Instructional expenditure per FTE enrollment ... } \\
\text { Research exp per tenured and tenure-track }\end{array}$ & 9 & 3,648 & 74 & 3,808 & -159 & -142 & -4.4 \\
\hline 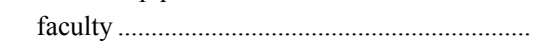 & 9 & 4,729 & 72 & 7,110 & $-2,381$ & $-2,117$ & -50.4 \\
\hline $\begin{array}{l}\text { Public service exp per tenured and tenure- } \\
\quad \text { track faculty }\end{array}$ & 9 & 16,768 & 72 & 15,693 & 1,075 & 955 & 6.4 \\
\hline Academic support expenditure per FTE & & & & & & & \\
\hline 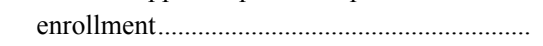 & 9 & 856 & 74 & 904 & -48 & -43 & -5.6 \\
\hline Average scholarship per FTE enrollment ............ & 9 & 1,302 & 74 & 1,556 & -253 & -226 & -19.5 \\
\hline Library expenditure per FTE enrollment............. & 9 & 350 & 74 & 327 & 23 & 21 & 6.6 \\
\hline
\end{tabular}

${ }^{1}$ Calculated as $\left(\mathrm{Y}_{1}-\mathrm{Y}_{2}\right) *\left(\mathrm{~N}_{2} /\left(\mathrm{N}_{1}+\mathrm{N}_{2}\right)\right)$.

SOURCE: University of Delaware, The Delaware Study of Instructional Costs and Productivity, 1997-2001; U.S. Department of Education, National Center for Education Statistics, Integrated Postsecondary Education Data System (IPEDS), Institutional Characteristics Surveys, 1997-2001. 
Table D-3. Nonresponse bias for 1999 Delaware Study, by institution's Carnegie classification

\begin{tabular}{|c|c|c|c|c|c|c|c|}
\hline \multirow{2}{*}{$\begin{array}{l}\text { Carnegie classification and } \\
\text { institutional characteristic }\end{array}$} & \multicolumn{2}{|c|}{ Participants } & \multicolumn{2}{|c|}{ Nonparticipants } & \multirow{2}{*}{$\begin{array}{r}\text { Difference } \\
\left(Y_{1}-Y_{2}\right)\end{array}$} & \multirow{2}{*}{$\begin{array}{l}\text { Magni- } \\
\text { tude of } \\
\text { bias }^{1}\end{array}$} & \multirow{2}{*}{$\begin{array}{r}\text { Percent } \\
\text { difference }\end{array}$} \\
\hline & $\mathrm{N}_{1}$ & $\operatorname{Avg}\left(Y_{1}\right)$ & $\mathrm{N}_{2}$ & $\operatorname{Avg}\left(Y_{2}\right)$ & & & \\
\hline \multicolumn{8}{|l|}{ Research } \\
\hline 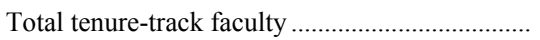 & 53 & 694 & 73 & 616 & 78 & 45 & 11.2 \\
\hline 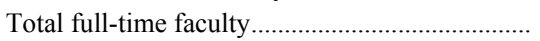 & 53 & 1,022 & 73 & 928 & 94 & 55 & 9.2 \\
\hline $\begin{array}{l}\text { Tenure-track faculty as percent of total full- } \\
\text { time faculty }\end{array}$ & 53 & 68 & 73 & 67 & 1 & 0 & 1.2 \\
\hline Total full-time-equivalent (FTE) enrollment...... & 53 & 21,179 & 73 & 16,919 & 4,260 & 2,468 & 20.1 \\
\hline Undergraduate enrollment as percent of total .... & 53 & 78 & 73 & 68 & 10 & 6 & 13.1 \\
\hline FTE enrollment per full-time faculty ....................... & 53 & 21 & 73 & 18 & 3 & 2 & 14.7 \\
\hline $\begin{array}{l}\text { Bachelor's degrees awarded as percent of } \\
\text { total }\end{array}$ & 53 & 65 & 73 & 58 & 8 & 5 & 11.9 \\
\hline Master's degrees awarded as percent of total..... & 53 & 25 & 73 & 28 & -3 & -2 & -13.6 \\
\hline Doctor's degrees awarded as percent of total..... & 53 & 10 & 73 & 14 & -4 & -3 & -45.4 \\
\hline Instructional expenditure per FTE enrollment ... & 47 & 7,187 & 38 & 8,947 & $-1,760$ & -787 & -24.5 \\
\hline $\begin{array}{l}\text { Research exp per tenured and tenure-track } \ldots \ldots . . . \\
\text { faculty }\end{array}$ & 47 & 144,026 & 38 & 187,891 & $-43,865$ & $-19,610$ & -30.5 \\
\hline $\begin{array}{l}\text { Public service exp per tenured and tenure- } \\
\text { track faculty }\end{array}$ & 47 & 55,352 & 38 & 52,469 & 2,883 & 1,289 & 5.2 \\
\hline $\begin{array}{l}\text { Academic support expenditure per FTE } \\
\text { enrollment }\end{array}$ & 47 & 1.826 & 38 & 3.653 & $-1,827$ & -817 & -100.1 \\
\hline 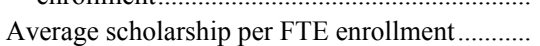 & 47 & 1,479 & 38 & 1,837 & -359 & -160 & -24.3 \\
\hline Library expenditure per FTE enrollment.............. & 47 & 605 & 38 & 712 & -107 & -48 & -17.7 \\
\hline \multicolumn{8}{|l|}{ Doctoral } \\
\hline 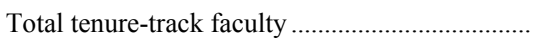 & 24 & 298 & 86 & 263 & 36 & 28 & 12.0 \\
\hline 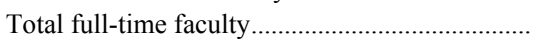 & 24 & 476 & 86 & 428 & 48 & 37 & 10.1 \\
\hline $\begin{array}{l}\text { Tenure-track faculty as percent of total full- } \\
\text { time faculty }\end{array}$ & 24 & 64 & 86 & 60 & 4 & 3 & 6.6 \\
\hline Total full-time-equivalent (FTE) enrollment...... & 24 & 9,979 & 86 & 8,962 & 1,017 & 795 & 10.2 \\
\hline Undergraduate enrollment as percent of total .... & 24 & 81 & 86 & 71 & 10 & 8 & 12.8 \\
\hline FTE enrollment per full-time faculty....................... & 24 & 20 & 86 & 21 & 0 & 0 & -1.6 \\
\hline Bachelor's degrees awarded as percent of & 24 & 67 & 86 & 57 & 10 & 8 & 15.1 \\
\hline Master's degrees awarded as percent of total..... & 24 & 27 & 86 & 33 & -6 & -4 & -20.9 \\
\hline Doctor's degrees awarded as percent of total..... & 24 & 6 & 86 & 10 & -5 & -4 & -81.8 \\
\hline $\begin{array}{l}\text { Instructional expenditure per FTE enrollment ... } \\
\text { Research exp per tenured and tenure-track }\end{array}$ & 20 & 5,575 & 44 & 5,638 & -63 & -44 & -1.1 \\
\hline 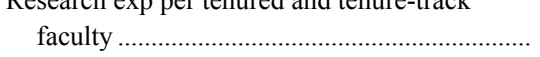 & 20 & 51,429 & 44 & 57,264 & $-5,834$ & $-4,011$ & -11.3 \\
\hline $\begin{array}{l}\text { Public service exp per tenured and tenure- } \\
\text { track faculty }\end{array}$ & 20 & 22,130 & 44 & 21,140 & 990 & 681 & 4.5 \\
\hline Academic support expenditure per FTE & 20 & 1,424 & 44 & 1,414 & 10 & 7 & 0.7 \\
\hline Average scholarship per FTE enrollment............ & 20 & 1,423 & 44 & 1,200 & 223 & 153 & 15.6 \\
\hline Library expenditure per FTE enrollment.............. & 20 & 541 & 44 & 465 & 76 & 52 & 14.0 \\
\hline $\begin{array}{l}\text { Comprehensive (not included in the survey) } \\
\text { Baccalaureate (not included in the survey) }\end{array}$ & & & & & & & \\
\hline
\end{tabular}

${ }^{1}$ Calculated as $\left(\mathrm{Y}_{1}-\mathrm{Y}_{2}\right) *\left(\mathrm{~N}_{2} /\left(\mathrm{N}_{1}+\mathrm{N}_{2}\right)\right)$.

SOURCE: University of Delaware, The Delaware Study of Instructional Costs and Productivity, 1997-2001; U.S. Department of Education, National Center for Education Statistics, Integrated Postsecondary Education Data System (IPEDS), Institutional Characteristics Surveys, 1997-2001. 
Table D-4. Nonresponse bias for 1998 Delaware Study, by institution's Carnegie classification

\begin{tabular}{|c|c|c|c|c|c|c|c|}
\hline \multirow{2}{*}{$\begin{array}{l}\text { Carnegie classification and } \\
\text { institutional characteristic }\end{array}$} & \multicolumn{2}{|c|}{ Participants } & \multicolumn{2}{|c|}{ Nonparticipants } & \multirow[b]{2}{*}{$\begin{array}{r}\text { Difference } \\
\left(Y_{1}-Y_{2}\right) \\
\end{array}$} & \multirow{2}{*}{$\begin{array}{r}\text { Magni- } \\
\text { tude of } \\
\text { bias }^{1}\end{array}$} & \multirow[b]{2}{*}{$\begin{array}{r}\text { Percent } \\
\text { difference }\end{array}$} \\
\hline & $\mathrm{N}_{1}$ & $\operatorname{Avg}\left(Y_{1}\right)$ & $\mathrm{N}_{2}$ & $\operatorname{Avg}\left(\mathrm{Y}_{2}\right)$ & & & \\
\hline \multicolumn{8}{|l|}{ Research } \\
\hline 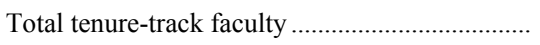 & 49 & 703 & 77 & 614 & 89 & 54 & 12.6 \\
\hline Total full-time faculty............................................ & 49 & 1,034 & 77 & 925 & 109 & 67 & 10.6 \\
\hline $\begin{array}{l}\text { Tenure-track faculty as percent of total full- } \\
\text { time faculty }\end{array}$ & 49 & 67 & 77 & 67 & 1 & 0 & 0.7 \\
\hline Total full-time-equivalent (FTE) enrollment...... & 49 & 21,154 & 77 & 17,156 & 3,998 & 2,443 & 18.9 \\
\hline Undergraduate enrollment as percent of total .... & 49 & 79 & 77 & 68 & 11 & 7 & 13.8 \\
\hline FTE enrollment per full-time faculty ...................... & 49 & 20 & 77 & 18 & 2 & 1 & 10.7 \\
\hline Bachelor's degrees awarded as percent of & 49 & 67 & 77 & 57 & 9 & 6 & 14.0 \\
\hline Master's degrees awarded as percent of total..... & 49 & 24 & 77 & 29 & -5 & -3 & -21.2 \\
\hline Doctor's degrees awarded as percent of total..... & 49 & 10 & 77 & 14 & -4 & -3 & -44.6 \\
\hline Instructional expenditure per FTE enrollment ... & 44 & 7,052 & 41 & 8,962 & $-1,910$ & -921 & -27.1 \\
\hline $\begin{array}{l}\text { Research exp per tenured and tenure-track } \\
\text { faculty }\end{array}$ & 44 & 146,536 & 41 & 181,987 & $-35,451$ & $-17,100$ & -24.2 \\
\hline $\begin{array}{l}\text { Public service exp per tenured and tenure- } \\
\text { track faculty }\end{array}$ & 44 & 55,827 & 41 & 52,169 & 3,658 & 1,764 & 6.6 \\
\hline Academic support expenditure per FTE & & & & & & & \\
\hline 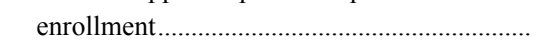 & 44 & 1,871 & 41 & 3,470 & $-1,598$ & -771 & -85.4 \\
\hline Average scholarship per FTE enrollment............. & 44 & 1,491 & 41 & 1,798 & -307 & -148 & -20.6 \\
\hline Library expenditure per FTE enrollment............. & 44 & 591 & 41 & 719 & -128 & -62 & -21.6 \\
\hline \multicolumn{8}{|l|}{ Doctoral } \\
\hline 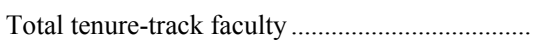 & 26 & 320 & 84 & 255 & 64 & 49 & 20.1 \\
\hline 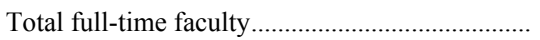 & 26 & 522 & 84 & 413 & 109 & 83 & 20.9 \\
\hline 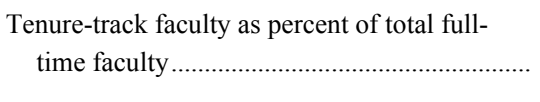 & 26 & 63 & 84 & 60 & 3 & 2 & 4.3 \\
\hline Total full-time-equivalent (FTE) enrollment...... & 26 & 11,181 & 84 & 8,565 & 2,616 & 1,998 & 23.4 \\
\hline Undergraduate enrollment as percent of total .... & 26 & 81 & 84 & 71 & 10 & 8 & 12.3 \\
\hline FTE enrollment per full-time faculty ...................... & 26 & 21 & 84 & 21 & 0 & 0 & 1.3 \\
\hline $\begin{array}{l}\text { Bachelor's degrees awarded as percent of } \\
\text { total }\end{array}$ & 26 & 66 & 84 & 57 & 9 & 7 & 13.7 \\
\hline Master's degrees awarded as percent of total..... & 26 & 28 & 84 & 33 & -4 & -3 & -14.7 \\
\hline Doctor's degrees awarded as percent of total..... & 26 & 5 & 84 & 10 & -5 & -4 & -95.2 \\
\hline Instructional expenditure per FTE enrollment ... & 22 & 5,320 & 42 & 5,775 & -455 & -298 & -8.5 \\
\hline $\begin{array}{l}\text { Research exp per tenured and tenure-track } \\
\text { faculty }\end{array}$ & 22 & 43,563 & 42 & 61,662 & $-18,099$ & $-11,878$ & -41.5 \\
\hline $\begin{array}{l}\text { Public service exp per tenured and tenure- } \\
\text { track faculty }\end{array}$ & 22 & 20,464 & 42 & 21,965 & $-1,501$ & -985 & -7.3 \\
\hline Academic support expenditure per FTE & 22 & 1425 & 42 & 1414 & 12 & 8 & 08 \\
\hline 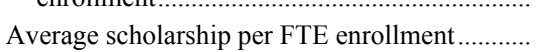 & 22 & 1,246 & 42 & 1,282 & -36 & -24 & $\begin{array}{l}.0 \\
-2.9\end{array}$ \\
\hline Library expenditure per FTE enrollment............. & 22 & 509 & 42 & 478 & 32 & 21 & 6.2 \\
\hline
\end{tabular}

See notes at the end of the table. 
Table D-4. Nonresponse bias for 1998 Delaware Study, by institution's Carnegie classification-Continued

\begin{tabular}{|c|c|c|c|c|c|c|c|}
\hline \multirow{2}{*}{$\begin{array}{l}\text { Carnegie classification and } \\
\text { institutional characteristic }\end{array}$} & \multicolumn{2}{|c|}{ Participants } & \multicolumn{2}{|c|}{ Nonparticipants } & \multirow{2}{*}{$\begin{array}{r}\text { Difference } \\
\left(\mathrm{Y}_{1}-\mathrm{Y}_{2}\right)\end{array}$} & \multirow{2}{*}{$\begin{array}{l}\text { Magni- } \\
\text { tude of } \\
\text { bias }^{1}\end{array}$} & \multirow{2}{*}{$\begin{array}{r}\text { Percent } \\
\text { difference }\end{array}$} \\
\hline & $\mathrm{N}_{1}$ & $\operatorname{Avg}\left(Y_{1}\right)$ & $\mathrm{N}_{2}$ & $\operatorname{Avg}\left(\mathrm{Y}_{2}\right)$ & & & \\
\hline \multicolumn{8}{|l|}{ Comprehensive } \\
\hline 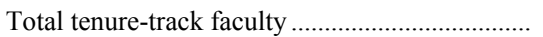 & 63 & 179 & 466 & 123 & 56 & 49 & 31.2 \\
\hline 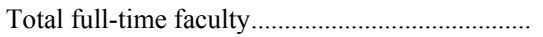 & 63 & 286 & 468 & 203 & 83 & 73 & 28.9 \\
\hline 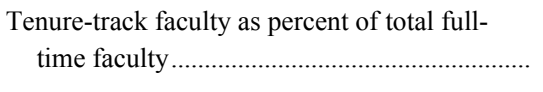 & 63 & 61 & 467 & 54 & 7 & 6 & 11.3 \\
\hline Total full-time-equivalent (FTE) enrollment...... & 63 & 5,995 & 468 & 4,524 & 1,471 & 1,296 & 24.5 \\
\hline Undergraduate enrollment as percent of total .... & 63 & 87 & 468 & 84 & 2 & 2 & 2.9 \\
\hline FTE enrollment per full-time faculty .................... & 63 & 21 & 466 & 25 & -4 & -3 & -18.9 \\
\hline \multicolumn{8}{|l|}{ Bachelor's degrees awarded as percent of } \\
\hline Master's degrees awarded as percent of total..... & 63 & 23 & 468 & 27 & -4 & -3 & -17.3 \\
\hline Doctor's degrees awarded as percent of total..... & 63 & 2 & 468 & 2 & 0 & 0 & 19.7 \\
\hline $\begin{array}{l}\text { Instructional expenditure per FTE enrollment ... } \\
\text { Research exp per tenured and tenure-track }\end{array}$ & 43 & 4,326 & 232 & 4,377 & -52 & -44 & -1.2 \\
\hline 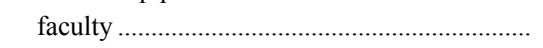 & 43 & 13,306 & 231 & 11,707 & 1,599 & 1,348 & 12.0 \\
\hline $\begin{array}{l}\text { Public service exp per tenured and tenure- } \\
\quad \text { track faculty }\end{array}$ & 43 & 15,923 & 231 & 13,114 & 2,810 & 2,369 & 17.6 \\
\hline Academic support expenditure per FTE & & & & & & & \\
\hline 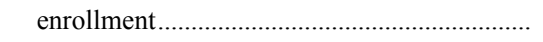 & 43 & 1,022 & 232 & 988 & 35 & 29 & 3.4 \\
\hline Average scholarship per FTE enrollment............ & 43 & 1,090 & 232 & 1,320 & -231 & -195 & -21.2 \\
\hline Library expenditure per FTE enrollment.............. & 43 & 372 & 232 & 360 & 13 & 11 & 3.4 \\
\hline \multicolumn{8}{|l|}{ Baccalaureate } \\
\hline Total full-time faculty............................................ & 15 & 112 & 610 & 77 & 35 & 34 & 31.2 \\
\hline $\begin{array}{l}\text { Tenure-track faculty as percent of total full- } \\
\text { time faculty }\end{array}$ & 15 & 54 & 607 & 48 & 6 & 6 & 11.6 \\
\hline Total full-time-equivalent (FTE) enrollment...... & 15 & 2,066 & 616 & 1,452 & 615 & 600 & 29.7 \\
\hline Undergraduate enrollment as percent of total .... & 15 & 96 & 616 & 96 & 0 & 0 & 0.4 \\
\hline FTE enrollment per full-time faculty ..................... & 15 & 19 & 606 & 20 & -1 & -1 & -6.1 \\
\hline Bachelor's degrees awarded as percent of & 15 & 96 & 611 & 94 & 2 & 2 & 2.1 \\
\hline Master's degrees awarded as percent of total..... & 15 & 4 & 611 & 5 & -1 & -1 & -29.9 \\
\hline $\begin{array}{l}\text { Instructional expenditure per FTE enrollment ... } \\
\text { Research exp per tenured and tenure-track }\end{array}$ & 9 & 3,418 & 74 & 3,836 & -418 & -373 & -12.2 \\
\hline 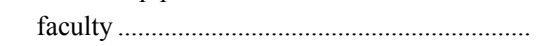 & 9 & 1,900 & 72 & 7,464 & $-5,564$ & $-4,945$ & -292.8 \\
\hline $\begin{array}{l}\text { Public service exp per tenured and tenure- } \\
\quad \text { track faculty }\end{array}$ & 9 & 23,595 & 72 & 14,840 & 8,755 & 7,783 & 37.1 \\
\hline Academic support expenditure per FTE & & & & & & & \\
\hline 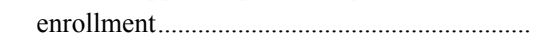 & 9 & 946 & 74 & 893 & 53 & 47 & 5.6 \\
\hline Average scholarship per FTE enrollment ............ & 9 & 1,360 & 74 & 1,549 & -188 & -168 & -13.8 \\
\hline Library expenditure per FTE enrollment............. & 9 & 305 & 74 & 333 & -28 & -25 & -9.1 \\
\hline
\end{tabular}

${ }^{1}$ Calculated as $\left(\mathrm{Y}_{1}-\mathrm{Y}_{2}\right) *\left(\mathrm{~N}_{2} /\left(\mathrm{N}_{1}+\mathrm{N}_{2}\right)\right)$.

SOURCE: University of Delaware, The Delaware Study of Instructional Costs and Productivity, 1997-2001; U.S. Department of Education, National Center for Education Statistics, Integrated Postsecondary Education Data System (IPEDS), Institutional Characteristics Surveys, 1997-2001. 
Table D-5. Nonresponse bias for 1997 Delaware Study, by institution's Carnegie classification

\begin{tabular}{|c|c|c|c|c|c|c|c|}
\hline \multirow{2}{*}{$\begin{array}{l}\text { Carnegie classification and } \\
\text { institutional characteristic }\end{array}$} & \multicolumn{2}{|c|}{ Participants } & \multicolumn{2}{|c|}{ Nonparticipants } & \multirow[b]{2}{*}{$\begin{array}{r}\text { Difference } \\
\left(Y_{1}-Y_{2}\right)\end{array}$} & \multirow{2}{*}{$\begin{array}{r}\text { Magni- } \\
\text { tude of } \\
\text { bias }^{1}\end{array}$} & \multirow[b]{2}{*}{$\begin{array}{r}\text { Percent } \\
\text { difference }\end{array}$} \\
\hline & $\mathrm{N}_{1}$ & $\operatorname{Avg}\left(Y_{1}\right)$ & $\mathrm{N}_{2}$ & $\operatorname{Avg}\left(\mathrm{Y}_{2}\right)$ & & & \\
\hline \multicolumn{8}{|l|}{ Research } \\
\hline 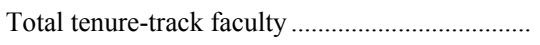 & 48 & 688 & 78 & 625 & 64 & 40 & 9.3 \\
\hline 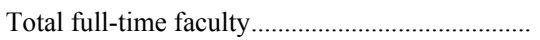 & 48 & 1,003 & 78 & 946 & 57 & 35 & 5.7 \\
\hline $\begin{array}{l}\text { Tenure-track faculty as percent of total full- } \\
\text { time faculty }\end{array}$ & 48 & 68 & 78 & 66 & 2 & 1 & 2.4 \\
\hline Total full-time-equivalent (FTE) enrollment....... & 48 & 21,161 & 78 & 17,202 & 3,959 & 2,451 & 18.7 \\
\hline Undergraduate enrollment as percent of total .... & 48 & 79 & 78 & 68 & 11 & 7 & 14.1 \\
\hline FTE enrollment per full-time faculty ....................... & 48 & 21 & 78 & 18 & 3 & 2 & 15.1 \\
\hline Bachelor's degrees awarded as percent of & 48 & 67 & 78 & 57 & 10 & 6 & 14.3 \\
\hline Master's degrees awarded as percent of total..... & 48 & 24 & 78 & 29 & -5 & -3 & -19.8 \\
\hline Doctor's degrees awarded as percent of total..... & 48 & 9 & 78 & 14 & -5 & -3 & -52.4 \\
\hline Instructional expenditure per FTE enrollment ... & 41 & 6,570 & 44 & 9,282 & $-2,712$ & $-1,404$ & -41.3 \\
\hline $\begin{array}{l}\text { Research exp per tenured and tenure-track } \\
\text { faculty }\end{array}$ & 41 & 138,841 & 44 & 186,741 & $-47,900$ & $-24,796$ & -34.5 \\
\hline $\begin{array}{l}\text { Public service exp per tenured and tenure- } \\
\text { track faculty }\end{array}$ & 41 & 58,345 & 44 & 50,073 & 8,272 & 4,282 & 14.2 \\
\hline Academic support expenditure per FTE & & & & & & & \\
\hline 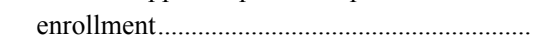 & 41 & 1,753 & 44 & 3,471 & $-1,719$ & -890 & -98.1 \\
\hline Average scholarship per FTE enrollment............ & 41 & 1,466 & 44 & 1,800 & -334 & -173 & -22.8 \\
\hline Library expenditure per FTE enrollment.............. & 41 & 568 & 44 & 732 & -164 & -85 & -29.0 \\
\hline \multicolumn{8}{|l|}{ Doctoral } \\
\hline 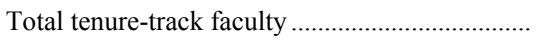 & 35 & 298 & 75 & 258 & 40 & 27 & 13.4 \\
\hline 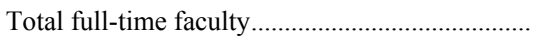 & 35 & 498 & 75 & 411 & 87 & 59 & 17.5 \\
\hline $\begin{array}{l}\text { Tenure-track faculty as percent of total full- } \\
\text { time faculty }\end{array}$ & 35 & 60 & 75 & 61 & -1 & -1 & -2.3 \\
\hline Total full-time-equivalent (FTE) enrollment...... & 35 & 10,762 & 75 & 8,447 & 2,316 & 1,579 & 21.5 \\
\hline Undergraduate enrollment as percent of total .... & 35 & 81 & 75 & 69 & 12 & 8 & 14.8 \\
\hline FTE enrollment per full-time faculty ...................... & 35 & 21 & 75 & 21 & 0 & 0 & 2.3 \\
\hline $\begin{array}{l}\text { Bachelor's degrees awarded as percent of } \\
\text { total }\end{array}$ & 35 & 67 & 75 & 56 & 10 & 7 & 15.6 \\
\hline Master's degrees awarded as percent of total..... & 35 & 28 & 75 & 33 & -6 & -4 & -19.8 \\
\hline Doctor's degrees awarded as percent of total..... & 35 & 6 & 75 & 11 & -5 & -3 & -84.5 \\
\hline Instructional expenditure per FTE enrollment ... & 27 & 5,476 & 37 & 5,723 & -247 & -143 & -4.5 \\
\hline $\begin{array}{l}\text { Research exp per tenured and tenure-track } \\
\text { faculty }\end{array}$ & 27 & 66,853 & 37 & 47,113 & 19,740 & 11,412 & 29.5 \\
\hline $\begin{array}{l}\text { Public service exp per tenured and tenure- } \\
\text { track faculty }\end{array}$ & 27 & 27,330 & 37 & 17,158 & 10,171 & 5,880 & 37.2 \\
\hline Academic support expenditure per FTE & 27 & 1,525 & 37 & 1,340 & 185 & 107 & 12.1 \\
\hline Average scholarship per FTE enrollment............. & 27 & 1,232 & 37 & 1,298 & -66 & -38 & -5.3 \\
\hline Library expenditure per FTE enrollment............. & 27 & 488 & 37 & 489 & 0 & 0 & 0.0 \\
\hline
\end{tabular}

See notes at the end of the table. 
Table D-5. Nonresponse bias for 1997 Delaware Study, by institution's Carnegie classification-Continued

\begin{tabular}{|c|c|c|c|c|c|c|c|}
\hline \multirow{2}{*}{$\begin{array}{l}\text { Carnegie classification and } \\
\text { institutional characteristic }\end{array}$} & \multicolumn{2}{|c|}{ Participants } & \multicolumn{2}{|c|}{ Nonparticipants } & \multirow{2}{*}{$\begin{array}{r}\text { Difference } \\
\left(\mathrm{Y}_{1}-\mathrm{Y}_{2}\right)\end{array}$} & \multirow{2}{*}{$\begin{array}{l}\text { Magni- } \\
\text { tude of } \\
\text { bias }^{1}\end{array}$} & \multirow{2}{*}{$\begin{array}{r}\text { Percent } \\
\text { difference }\end{array}$} \\
\hline & $\mathrm{N}_{1}$ & $\operatorname{Avg}\left(Y_{1}\right)$ & $\mathrm{N}_{2}$ & $\operatorname{Avg}\left(\mathrm{Y}_{2}\right)$ & & & \\
\hline \multicolumn{8}{|l|}{ Comprehensive } \\
\hline 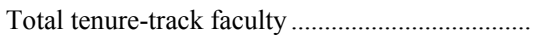 & 54 & 189 & 475 & 123 & 66 & 59 & 34.9 \\
\hline 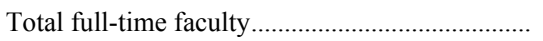 & 54 & 305 & 477 & 202 & 103 & 93 & 33.8 \\
\hline 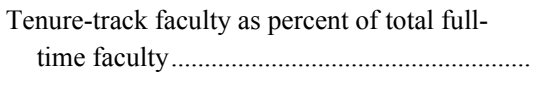 & 54 & 61 & 476 & 55 & 7 & 6 & 10.8 \\
\hline Total full-time-equivalent (FTE) enrollment...... & 54 & 6,723 & 477 & 4,469 & 2,253 & 2,024 & 33.5 \\
\hline Undergraduate enrollment as percent of total .... & 54 & 88 & 477 & 84 & 4 & 4 & 5.0 \\
\hline FTE enrollment per full-time faculty ..................... & 54 & 22 & 475 & 25 & -3 & -3 & -13.6 \\
\hline \multicolumn{8}{|l|}{ Bachelor's degrees awarded as percent of } \\
\hline Master's degrees awarded as percent of total..... & 54 & 22 & 477 & 27 & -5 & -5 & -23.9 \\
\hline Doctor's degrees awarded as percent of total..... & 54 & 2 & 477 & 2 & 0 & 0 & 2.4 \\
\hline $\begin{array}{l}\text { Instructional expenditure per FTE enrollment ... } \\
\text { Research exp per tenured and tenure-track }\end{array}$ & 39 & 4,089 & 236 & 4,416 & -326 & -280 & -8.0 \\
\hline 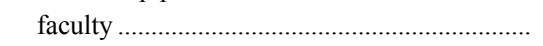 & 39 & 11,360 & 235 & 12,057 & -696 & -597 & -6.1 \\
\hline $\begin{array}{l}\text { Public service exp per tenured and tenure- } \\
\quad \text { track faculty }\end{array}$ & 39 & 13,550 & 235 & 13,555 & -5 & -4 & 0.0 \\
\hline Academic support expenditure per FTE & & & & & & & \\
\hline 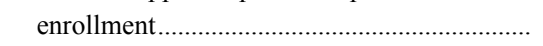 & 39 & 895 & 236 & 1,009 & -114 & -98 & -12.7 \\
\hline Average scholarship per FTE enrollment............ & 39 & 1,058 & 236 & 1,322 & -264 & -227 & -25.0 \\
\hline Library expenditure per FTE enrollment.............. & 39 & 350 & 236 & 363 & -13 & -11 & -3.7 \\
\hline \multicolumn{8}{|l|}{ Baccalaureate } \\
\hline Total full-time faculty............................................ & 13 & 132 & 612 & 76 & 56 & 55 & 42.2 \\
\hline $\begin{array}{l}\text { Tenure-track faculty as percent of total full- } \\
\text { time faculty }\end{array}$ & 13 & 67 & 609 & 48 & 19 & 19 & 28.9 \\
\hline Total full-time-equivalent (FTE) enrollment...... & 13 & 2,179 & 618 & 1,451 & 728 & 713 & 33.4 \\
\hline Undergraduate enrollment as percent of total .... & 13 & 95 & 618 & 96 & -1 & -1 & -1.2 \\
\hline FTE enrollment per full-time faculty ..................... & 13 & 17 & 608 & 20 & -3 & -3 & -20.2 \\
\hline Bachelor's degrees awarded as percent of & 13 & 90 & 613 & 94 & -4 & -4 & -4.4 \\
\hline Master's degrees awarded as percent of total..... & 13 & 10 & 613 & 5 & 5 & 4 & 46.8 \\
\hline $\begin{array}{l}\text { Instructional expenditure per FTE enrollment ... } \\
\text { Research exp per tenured and tenure-track }\end{array}$ & 2 & 4,067 & 81 & 3,784 & 284 & 277 & 7.0 \\
\hline 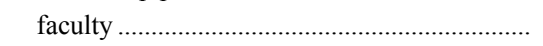 & 2 & 6,839 & 79 & 6,846 & -7 & -6 & -0.1 \\
\hline $\begin{array}{l}\text { Public service exp per tenured and tenure- } \\
\quad \text { track faculty }\end{array}$ & 2 & 18,473 & 79 & 15,745 & 2,728 & 2,661 & 14.8 \\
\hline 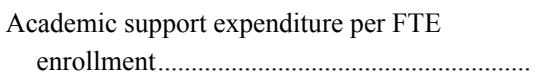 & 2 & 811 & 81 & 901 & -89 & -87 & -11.0 \\
\hline Average scholarship per FTE enrollment............ & 2 & 1,114 & 81 & 1,539 & -425 & -415 & -38.2 \\
\hline Library expenditure per FTE enrollment............. & 2 & 438 & 81 & 327 & 110 & 108 & 25.2 \\
\hline
\end{tabular}

${ }^{1}$ Calculated as $\left(\mathrm{Y}_{1}-\mathrm{Y}_{2}\right) *\left(\mathrm{~N}_{2} /\left(\mathrm{N}_{1}+\mathrm{N}_{2}\right)\right)$.

SOURCE: University of Delaware, The Delaware Study of Instructional Costs and Productivity, 1997-2001; U.S. Department of Education, National Center for Education Statistics, Integrated Postsecondary Education Data System (IPEDS), Institutional Characteristics Surveys, $1997-2001$. 
Table D-6. Results of the ANOVA to test for differences in average cost of instruction, by discipline and Carnegie classification of the institution, highest degree offered, and undergraduate/graduate program mix in discipline: 1998, 2000, and 2001 Delaware Study

\begin{tabular}{|c|c|c|c|c|c|c|c|}
\hline Factor and data collection cycle & & $\begin{array}{r}\text { Source of } \\
\text { variation }\end{array}$ & $\begin{array}{r}\text { Degrees of } \\
\text { freedom }\end{array}$ & $\begin{array}{l}\text { Sum of } \\
\text { squares }\end{array}$ & Mean square & F-value & $\begin{array}{r}\text { Probability } \\
\text { of } \mathrm{F}\end{array}$ \\
\hline \multicolumn{8}{|c|}{ Carnegie class (CC) by discipline (CIP) } \\
\hline \multicolumn{8}{|c|}{1998} \\
\hline & & $\mathrm{CC}$ & 2 & 4.8861 & 2.4430 & 85.24 & $<.0001$ \\
\hline & & CIP & 24 & 32.1579 & 1.3399 & 46.75 & $<.0001$ \\
\hline & & CC X CIP & 48 & 3.8341 & 0.0799 & 2.79 & $<.0001$ \\
\hline & & Error & 3,099 & 88.8238 & 0.0287 & & \\
\hline \multicolumn{8}{|c|}{2000} \\
\hline & & $\mathrm{CC}$ & 2 & 5.3914 & 2.6957 & 102.42 & $<.0001$ \\
\hline & & CIP & 24 & 43.6920 & 1.8205 & 69.17 & $<.0001$ \\
\hline & & CC X CIP & 48 & 2.6104 & 0.0544 & 2.07 & $<.0001$ \\
\hline & & Error & 3,140 & 82.6453 & 0.0263 & & \\
\hline \multicolumn{8}{|c|}{2001} \\
\hline & & $\mathrm{CC}$ & 2 & 4.9285 & 2.4643 & 86.16 & $<.0001$ \\
\hline & & CIP & 24 & 48.5772 & 2.0241 & 70.77 & $<.0001$ \\
\hline & & CC X CIP & 48 & 2.7734 & 0.0578 & 2.02 & $<.0001$ \\
\hline & & Error & 3,653 & 104.4761 & 0.0286 & & \\
\hline \multicolumn{8}{|c|}{$\begin{array}{l}\text { Highest degree offered (HD) by discipline } \\
\text { (CIP) }\end{array}$} \\
\hline \multicolumn{8}{|c|}{1998} \\
\hline & & HD & 2 & 6.0696 & 3.0348 & 113.4 & $<.0001$ \\
\hline & & CIP & 24 & 27.7793 & 1.1575 & 43.25 & $<.0001$ \\
\hline & & HD X CIP & 48 & 3.6752 & 0.0766 & 2.86 & $<.0001$ \\
\hline & & Error & 2,972 & 79.5361 & 0.0268 & & \\
\hline \multicolumn{8}{|c|}{2000} \\
\hline & & HD & 2 & 5.1815 & 2.5907 & 104.34 & $<.0001$ \\
\hline & & CIP & 24 & 34.8753 & 1.4531 & 58.52 & $<.0001$ \\
\hline & & HD X CIP & 48 & 3.8069 & 0.0793 & 3.19 & $<.0001$ \\
\hline & & Error & 3,067 & 76.1559 & 0.0248 & & \\
\hline & 2001 & & & & & & \\
\hline & & HD & 2 & 5.2497 & 2.6248 & 98.88 & $<.0001$ \\
\hline & & CIP & 24 & 38.1435 & 1.5893 & 59.87 & $<.0001$ \\
\hline & & HD X CIP & 48 & 2.9195 & 0.0608 & 2.29 & $<.0001$ \\
\hline & & Error & 3,540 & 93.9682 & 0.0265 & & \\
\hline \multicolumn{8}{|c|}{$\begin{array}{l}\text { Undergraduate/graduate mix (UGG) by } \\
\text { discipline(CIP) }\end{array}$} \\
\hline \multicolumn{8}{|l|}{$\mathrm{x}_{\mathrm{P}}+\mathrm{C}_{2}$} \\
\hline & & UGG & 1 & 2.4526 & 2.4526 & 77.9 & $<.0001$ \\
\hline & & CIP & 24 & 37.5560 & 1.5648 & 49.7 & $<.0001$ \\
\hline & & UGG X CIP & 24 & 2.5507 & 0.1063 & 3.38 & $<.0001$ \\
\hline & & Error & 3,004 & 94.5782 & 0.0315 & & \\
\hline \multicolumn{8}{|c|}{2000} \\
\hline & & UGG & 1 & 2.1884 & 2.1884 & 78.62 & $<.0001$ \\
\hline & & CIP & 24 & 44.1356 & 1.8390 & 66.06 & $<.0001$ \\
\hline & & UGG X CIP & 24 & 2.1691 & 0.0904 & 3.25 & $<.0001$ \\
\hline & & Error & 3,033 & 84.4280 & 0.0278 & & \\
\hline \multicolumn{8}{|c|}{2001} \\
\hline & & UGG & 1 & 2.4208 & 2.4208 & 78.72 & $<.0001$ \\
\hline & & CIP & 24 & 43.8759 & 1.8282 & 59.45 & $<.0001$ \\
\hline & & UGG X CIP & 24 & 2.5170 & 0.1049 & 3.41 & $<.0001$ \\
\hline & & Error & 3,569 & 109.7507 & 0.0308 & & \\
\hline
\end{tabular}

SOURCE: University of Delaware, The Delaware Study of Instructional Costs and Productivity, 1998-2001. 
Table D-7. Pairwise multiple comparison of cost of instruction by discipline within Carnegie classification based on the Bonferroni procedure at the 5 percent of level of significance: 2001 Delaware Study

\begin{tabular}{|c|c|c|c|c|c|c|c|c|c|c|}
\hline $\begin{array}{l}\text { Carnegie classification } \\
\text { and discipline }\end{array}$ & $\begin{array}{r}\text { Sample } \\
\text { size }\end{array}$ & $\begin{array}{r}\text { Average } \\
\text { cost } / \mathrm{SCH}\end{array}$ & \multicolumn{8}{|c|}{ Groupings $^{1}$} \\
\hline \multicolumn{11}{|l|}{ Research } \\
\hline Sociology & 33 & 124 & a & & & & & & & \\
\hline 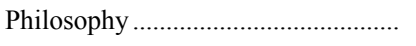 & 47 & 137 & a & & & & & & & \\
\hline 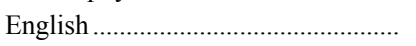 & 50 & 140 & a & & & & & & & \\
\hline 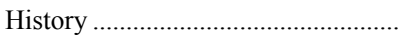 & 37 & 149 & a & $\mathrm{b}$ & & & & & & \\
\hline 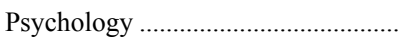 & 39 & 150 & a & $\mathrm{b}$ & & & & & & \\
\hline 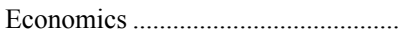 & 28 & 153 & a & $\mathrm{b}$ & & & & & & \\
\hline Anthropology & 27 & 157 & a & $\mathrm{b}$ & & & & & & \\
\hline 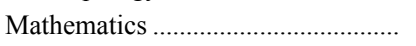 & 53 & 160 & a & $\mathrm{b}$ & & & & & & \\
\hline 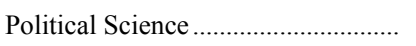 & 33 & 164 & a & $\mathrm{b}$ & $\mathrm{c}$ & & & & & \\
\hline 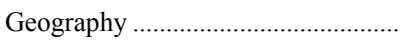 & 23 & 164 & a & $\mathrm{b}$ & $\mathrm{c}$ & & & & & \\
\hline 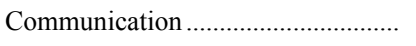 & 45 & 169 & a & $\mathrm{b}$ & $\mathrm{c}$ & & & & & \\
\hline 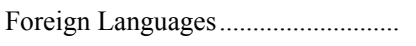 & 84 & 171 & a & $\mathrm{b}$ & $\mathrm{c}$ & & & & & \\
\hline 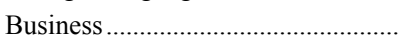 & 128 & 177 & a & $\mathrm{b}$ & $\mathrm{c}$ & & & & & \\
\hline 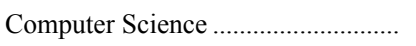 & 34 & 204 & & $\mathrm{~b}$ & $\mathrm{c}$ & $\mathrm{d}$ & & & & \\
\hline Geology & 30 & 211 & & $\mathrm{~b}$ & $\mathrm{c}$ & $\mathrm{d}$ & & & & \\
\hline Art & 114 & 228 & & & $\mathrm{c}$ & d & & & & \\
\hline Education & 96 & 260 & & & & $\mathrm{~d}$ & & & & \\
\hline 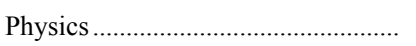 & 33 & 263 & & & & $\mathrm{~d}$ & $\mathrm{e}$ & & & \\
\hline 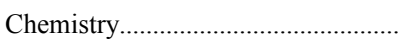 & 35 & 264 & & & & $\mathrm{~d}$ & $\mathrm{e}$ & & & \\
\hline 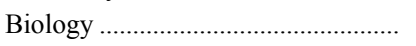 & 82 & 276 & & & & $\mathrm{~d}$ & $\mathrm{e}$ & & & \\
\hline 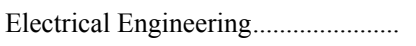 & 24 & 359 & & & & & $\mathrm{e}$ & $\mathrm{f}$ & & \\
\hline Mechanical Engineering ....................... & 26 & 379 & & & & & $\mathrm{e}$ & $\mathrm{f}$ & & \\
\hline 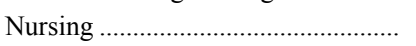 & 17 & 388 & & & & & $\mathrm{e}$ & $\mathrm{f}$ & & \\
\hline 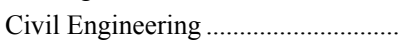 & 27 & 411 & & & & & $\mathrm{e}$ & $\mathrm{f}$ & & \\
\hline 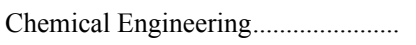 & 25 & 472 & & & & & & $\mathrm{f}$ & & \\
\hline \multicolumn{11}{|l|}{ Doctoral } \\
\hline 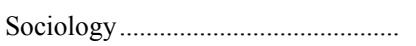 & 25 & 106 & a & & & & & & & \\
\hline 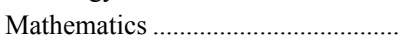 & 34 & 116 & a & $\mathrm{b}$ & & & & & & \\
\hline 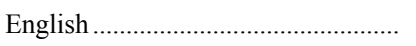 & 37 & 116 & a & $\mathrm{b}$ & & & & & & \\
\hline 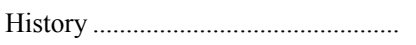 & 29 & 124 & a & $\mathrm{b}$ & & & & & & \\
\hline 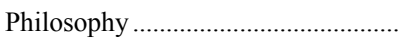 & 34 & 125 & a & $\mathrm{b}$ & & & & & & \\
\hline 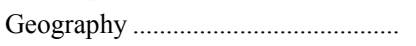 & 16 & 125 & a & $\mathrm{b}$ & & & & & & \\
\hline 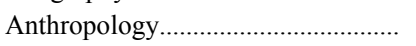 & 16 & 126 & a & $\mathrm{b}$ & $\mathrm{c}$ & & & & & \\
\hline 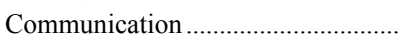 & 34 & 130 & a & $\mathrm{b}$ & $\mathrm{c}$ & & & & & \\
\hline 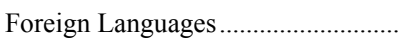 & 37 & 131 & a & $\mathrm{b}$ & $\mathrm{c}$ & & & & & \\
\hline 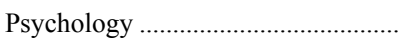 & 34 & 131 & a & $\mathrm{b}$ & $\mathrm{c}$ & & & & & \\
\hline Computer Science ….............................. & 28 & 142 & a & $\mathrm{b}$ & $\mathrm{c}$ & d & & & & \\
\hline 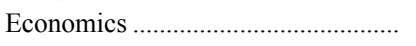 & 19 & 144 & a & $\mathrm{b}$ & $\mathrm{c}$ & $\mathrm{d}$ & & & & \\
\hline 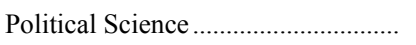 & 27 & 152 & a & $\mathrm{b}$ & $\mathrm{c}$ & $\mathrm{d}$ & & & & \\
\hline 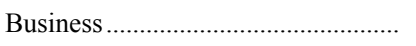 & 97 & 157 & & $\mathrm{~b}$ & $\mathrm{c}$ & $\mathrm{d}$ & & & & \\
\hline 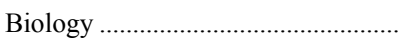 & 41 & 191 & & $\mathrm{~b}$ & $\mathrm{c}$ & $\mathrm{d}$ & $\mathrm{e}$ & & & \\
\hline 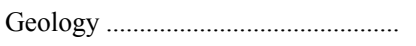 & 22 & 197 & & $\mathrm{~b}$ & $\mathrm{c}$ & $\mathrm{d}$ & $\mathrm{e}$ & & & \\
\hline 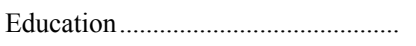 & 77 & 198 & & & $\mathrm{c}$ & $\mathrm{d}$ & $\mathrm{e}$ & & & \\
\hline Art & 84 & 199 & & & & $\mathrm{~d}$ & $\mathrm{e}$ & & & \\
\hline 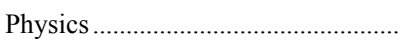 & 29 & 203 & & & & $\mathrm{~d}$ & $\mathrm{e}$ & $\mathrm{f}$ & & \\
\hline 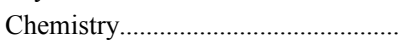 & 30 & 233 & & & & $\mathrm{~d}$ & $\mathrm{e}$ & $\mathrm{f}$ & $\mathrm{g}$ & \\
\hline 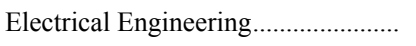 & 17 & 276 & & & & & $\mathrm{e}$ & $\mathrm{f}$ & $\mathrm{g}$ & $\mathrm{h}$ \\
\hline 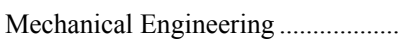 & 17 & 315 & & & & & & $\mathrm{f}$ & $\mathrm{g}$ & $\mathrm{h}$ \\
\hline 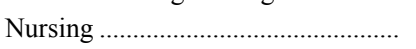 & 21 & 332 & & & & & & & $\mathrm{~g}$ & $\mathrm{~h}$ \\
\hline 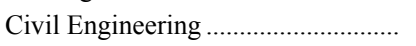 & 14 & 379 & & & & & & & & $\mathrm{~h}$ \\
\hline 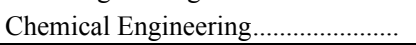 & 9 & 524 & & & & & & & & $\mathrm{~h}$ \\
\hline
\end{tabular}

See notes at the end of the table. 
Table D-7. Pairwise multiple comparison of cost of instruction by discipline within Carnegie classification based on the Bonferroni procedure at the 5 percent of level of significance: 2001 Delaware Study-Continued

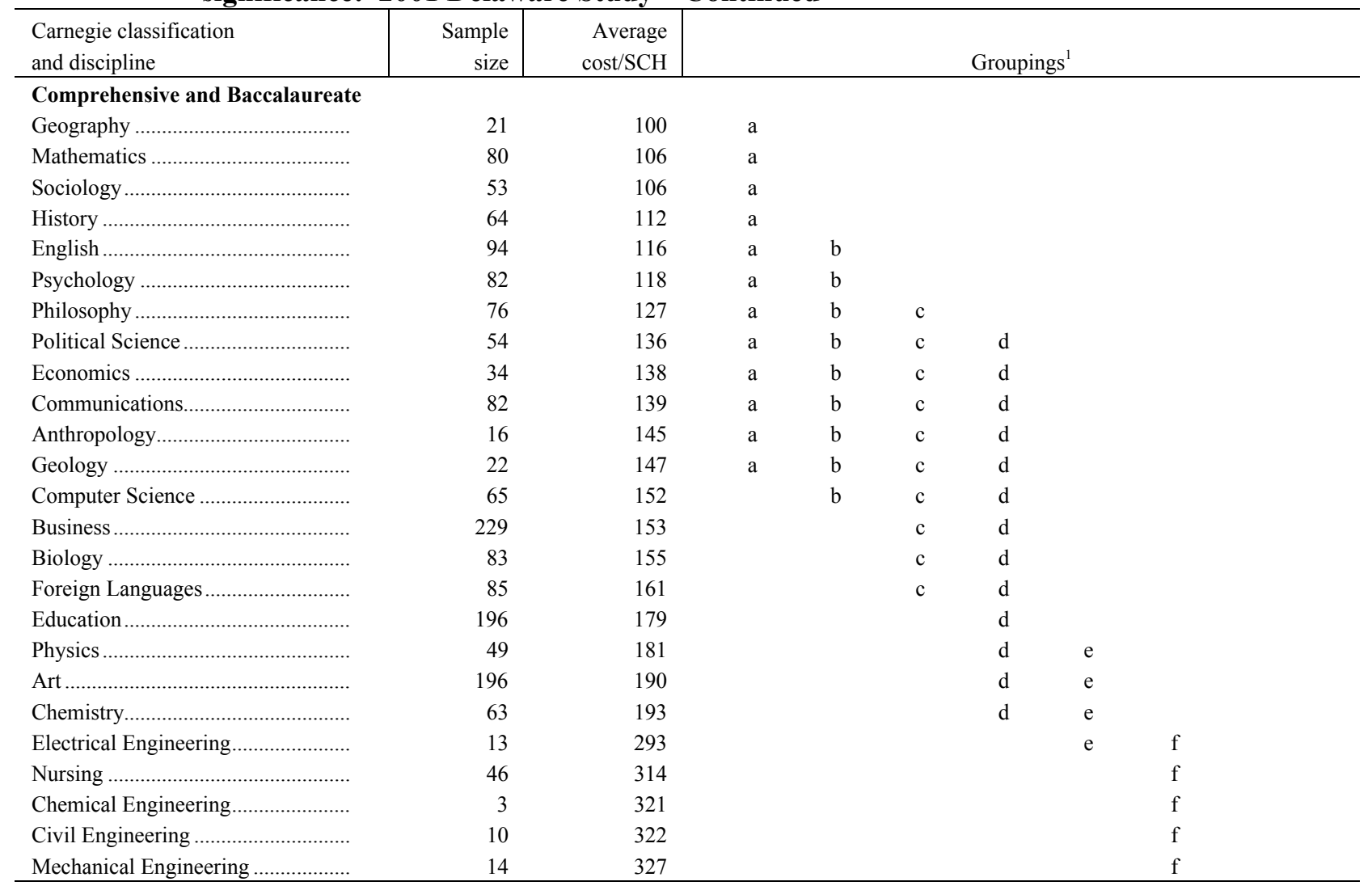

${ }^{1}$ Disciplines that are assigned the same letter are not different from each other with respect to instructional cost. It is possible for a discipline to be in more than one group.

SOURCE: University of Delaware, The Delaware Study of Instructional Costs and Productivity, 1998-2001. 
Table D-8. Pairwise multiple comparison of cost instruction by discipline within Carnegie classification based on the Bonferroni procedure at the 5 percent level of significance: 2000 Delaware Study

\begin{tabular}{|c|c|c|c|c|c|c|c|c|}
\hline \multirow{2}{*}{$\begin{array}{l}\text { Carnegie classification and discipline } \\
\text { Research }\end{array}$} & \multirow[t]{2}{*}{$\begin{array}{r}\text { Sample } \\
\text { size } \\
\end{array}$} & \multirow[t]{2}{*}{$\begin{array}{r}\text { Average } \\
\text { cost/SCH }\end{array}$} & \multicolumn{6}{|c|}{ Groupings $^{1}$} \\
\hline & & & & & & & & \\
\hline Sociology & 35 & 130 & a & & & & & \\
\hline 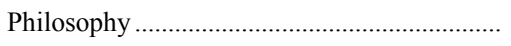 & 48 & 134 & a & & & & & \\
\hline 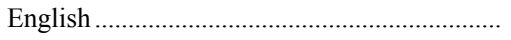 & 56 & 138 & $\mathrm{a}$ & & & & & \\
\hline 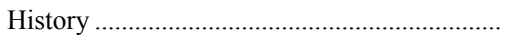 & 37 & 142 & a & $\mathrm{b}$ & & & & \\
\hline 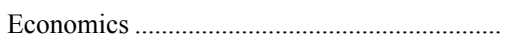 & 31 & 145 & $\mathrm{a}$ & $\mathrm{b}$ & & & & \\
\hline 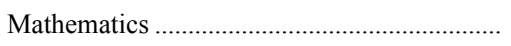 & 54 & 147 & $\mathrm{a}$ & $\mathrm{b}$ & & & & \\
\hline Anthropology & 28 & 148 & a & $\mathrm{b}$ & & & & \\
\hline 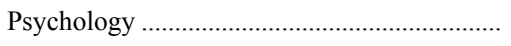 & 40 & 150 & $\mathrm{a}$ & $\mathrm{b}$ & & & & \\
\hline 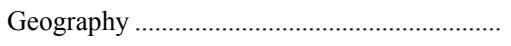 & 25 & 155 & a & $\mathrm{b}$ & & & & \\
\hline Communication & 49 & 164 & $\mathrm{a}$ & $\mathrm{b}$ & & & & \\
\hline 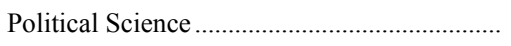 & 36 & 168 & a & $\mathrm{b}$ & & & & \\
\hline 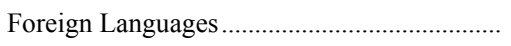 & 90 & 169 & a & $\mathrm{b}$ & & & & \\
\hline 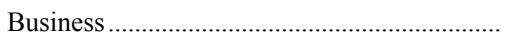 & 132 & 172 & a & $\mathrm{b}$ & & & & \\
\hline Computer Science & 36 & 203 & & $\mathrm{~b}$ & $\mathrm{c}$ & & & \\
\hline Art & 115 & 214 & & & $\mathrm{c}$ & & & \\
\hline 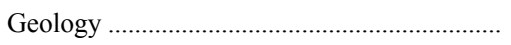 & 35 & 223 & & & $\mathrm{c}$ & & & \\
\hline 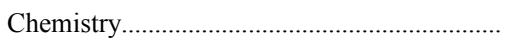 & 37 & 255 & & & c & $\mathrm{d}$ & & \\
\hline 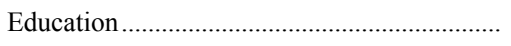 & 104 & 269 & & & $\mathrm{c}$ & $\mathrm{d}$ & & \\
\hline 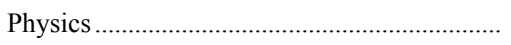 & 38 & 284 & & & $\mathrm{c}$ & $\mathrm{d}$ & $\mathrm{e}$ & \\
\hline 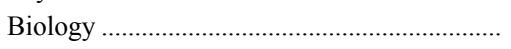 & 99 & 286 & & & $\mathrm{c}$ & $\mathrm{d}$ & $\mathrm{e}$ & \\
\hline 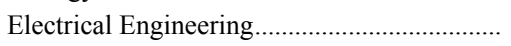 & 31 & 358 & & & & $\mathrm{~d}$ & $\mathrm{e}$ & $\mathrm{f}$ \\
\hline 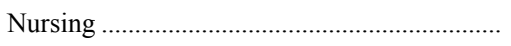 & 19 & 368 & & & & $\mathrm{~d}$ & $\mathrm{e}$ & $\mathrm{f}$ \\
\hline 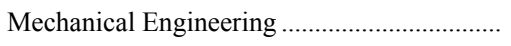 & 30 & 400 & & & & & $\mathrm{e}$ & $\mathrm{f}$ \\
\hline 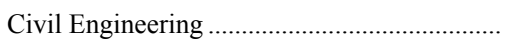 & 30 & 401 & & & & & $\mathrm{e}$ & $\mathrm{f}$ \\
\hline 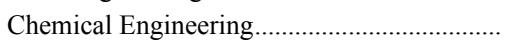 & 27 & 484 & & & & & & $\mathrm{f}$ \\
\hline \multicolumn{9}{|l|}{ Doctoral } \\
\hline Sociology & 14 & 104 & a & & & & & \\
\hline 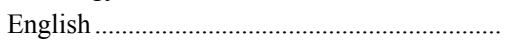 & 29 & 113 & $\mathrm{a}$ & & & & & \\
\hline Anthropology & 10 & 121 & $\mathrm{a}$ & $\mathrm{b}$ & & & & \\
\hline 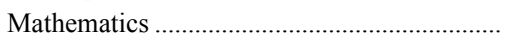 & 26 & 123 & a & $\mathrm{b}$ & & & & \\
\hline 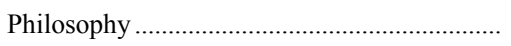 & 24 & 124 & $\mathrm{a}$ & $\mathrm{b}$ & & & & \\
\hline 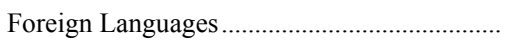 & 25 & 125 & a & $\mathrm{b}$ & & & & \\
\hline 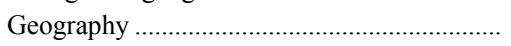 & 10 & 126 & a & $\mathrm{b}$ & & & & \\
\hline 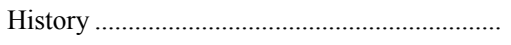 & 20 & 127 & a & $\mathrm{b}$ & & & & \\
\hline 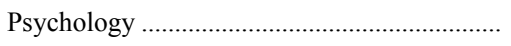 & 23 & 136 & a & $\mathrm{b}$ & $\mathrm{c}$ & & & \\
\hline 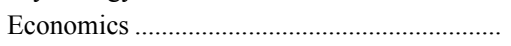 & 14 & 139 & $\mathrm{a}$ & $\mathrm{b}$ & $\mathrm{c}$ & & & \\
\hline Communication & 26 & 143 & a & $\mathrm{b}$ & c & & & \\
\hline 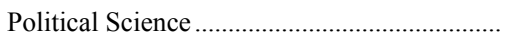 & 18 & 151 & a & $\mathrm{b}$ & c & & & \\
\hline 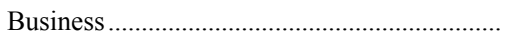 & 60 & 163 & $\mathrm{a}$ & $\mathrm{b}$ & $\mathrm{c}$ & & & \\
\hline Computer Science & 18 & 167 & a & $\mathrm{b}$ & $\mathrm{c}$ & & & \\
\hline Education & 54 & 183 & & $\mathrm{~b}$ & $\mathrm{c}$ & & & \\
\hline 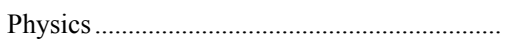 & 21 & 191 & & $\mathrm{~b}$ & $\mathrm{c}$ & $\mathrm{d}$ & & \\
\hline 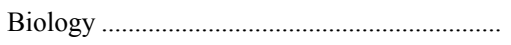 & 27 & 200 & & $\mathrm{~b}$ & c & $\mathrm{d}$ & & \\
\hline Art & 58 & 201 & & $\mathrm{~b}$ & $\mathrm{c}$ & $\mathrm{d}$ & & \\
\hline Geology fon. & 18 & 201 & & $\mathrm{~b}$ & $\mathrm{c}$ & $\mathrm{d}$ & & \\
\hline 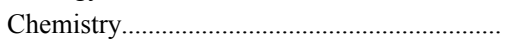 & 22 & 221 & & & $\mathrm{c}$ & $\mathrm{d}$ & e & \\
\hline 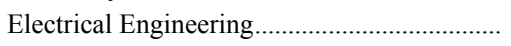 & 13 & 318 & & & & $\mathrm{~d}$ & e & $\mathrm{f}$ \\
\hline 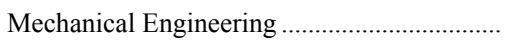 & 12 & 353 & & & & & $\mathrm{e}$ & $\mathrm{f}$ \\
\hline Nursing & 15 & 357 & & & & & $\mathrm{e}$ & $\mathrm{f}$ \\
\hline 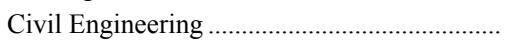 & 9 & 367 & & & & & $\mathrm{e}$ & $\mathrm{f}$ \\
\hline 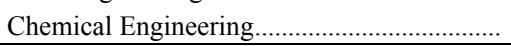 & 8 & 474 & & & & & & $\mathrm{f}$ \\
\hline
\end{tabular}

See notes at the end of the table. 
Table D-8. Pairwise multiple comparison of cost instruction by discipline within Carnegie classification based on the Bonferroni procedure at the 5 percent level of significance: 2000 Delaware Study - Continued

\begin{tabular}{|c|c|c|c|c|c|c|c|c|}
\hline Carnegie classification and discipline & $\begin{array}{r}\text { Sample } \\
\text { size }\end{array}$ & $\begin{array}{r}\text { Average } \\
\text { Cost } / \mathrm{SCH}\end{array}$ & \multicolumn{6}{|c|}{ Groupings $^{1}$} \\
\hline \multicolumn{9}{|l|}{ Comprehensive and Baccalaureate } \\
\hline 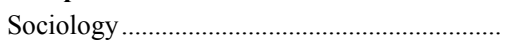 & 46 & 100 & a & & & & & \\
\hline 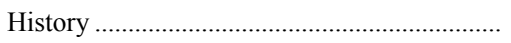 & 52 & 100 & a & & & & & \\
\hline Anthropology & 13 & 103 & a & $\mathrm{b}$ & & & & \\
\hline 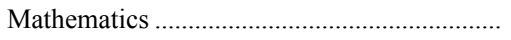 & 65 & 106 & a & $\mathrm{b}$ & & & & \\
\hline 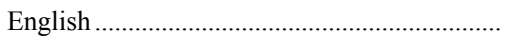 & 77 & 111 & a & $\mathrm{b}$ & & & & \\
\hline 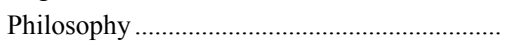 & 50 & 111 & a & $\mathrm{b}$ & & & & \\
\hline 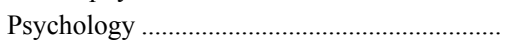 & 64 & 113 & a & $\mathrm{b}$ & & & & \\
\hline 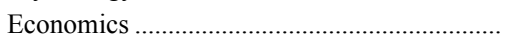 & 21 & 117 & $\mathrm{a}$ & $\mathrm{b}$ & $\mathrm{c}$ & & & \\
\hline 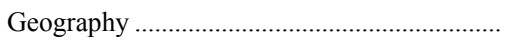 & 19 & 121 & a & $\mathrm{b}$ & $\mathrm{c}$ & & & \\
\hline 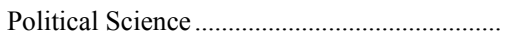 & 40 & 129 & a & $\mathrm{b}$ & $\mathrm{c}$ & & & \\
\hline 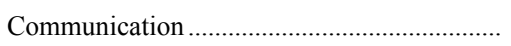 & 63 & 133 & a & $\mathrm{b}$ & $\mathrm{c}$ & & & \\
\hline 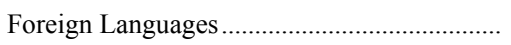 & 54 & 137 & a & $\mathrm{b}$ & $\mathrm{c}$ & & & \\
\hline Computer Science & 51 & 138 & $\mathrm{a}$ & $\mathrm{b}$ & $\mathrm{c}$ & $\mathrm{d}$ & & \\
\hline Biology & 66 & 141 & & $\mathrm{~b}$ & $\mathrm{c}$ & $\mathrm{d}$ & & \\
\hline 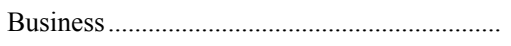 & 193 & 150 & & $\mathrm{~b}$ & $\mathrm{c}$ & $\mathrm{d}$ & & \\
\hline 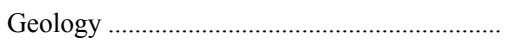 & 20 & 158 & & $\mathrm{~b}$ & $\mathrm{c}$ & $\mathrm{d}$ & e & \\
\hline 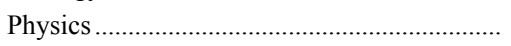 & 39 & 168 & & & $\mathrm{c}$ & $\mathrm{d}$ & $\mathrm{e}$ & \\
\hline 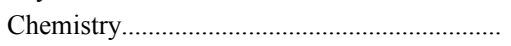 & 49 & 172 & & & $\mathrm{c}$ & $\mathrm{d}$ & e & \\
\hline Art & 155 & 174 & & & $\mathrm{c}$ & $\mathrm{d}$ & e & \\
\hline 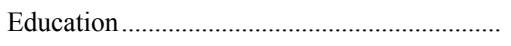 & 168 & 183 & & & & $\mathrm{~d}$ & e & \\
\hline 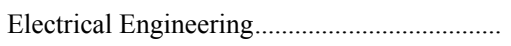 & 10 & 278 & & & & & $\mathrm{e}$ & $\mathrm{f}$ \\
\hline 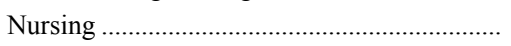 & 42 & 323 & & & & & & $\mathrm{f}$ \\
\hline 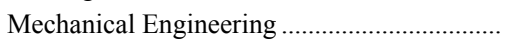 & 10 & 333 & & & & & & $\mathrm{f}$ \\
\hline 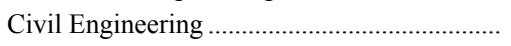 & 8 & 362 & & & & & & $\mathrm{f}$ \\
\hline Chemical Engineering ...................................... & 4 & 460 & & & & & & $\mathrm{f}$ \\
\hline
\end{tabular}

${ }^{1}$ Disciplines that are assigned the same letter are not different from each other with respect to instructional cost. It is possible for a discipline to be in more than one group.

SOURCE: University of Delaware, The Delaware Study of Instructional Costs and Productivity, 1998-2001. 
Table D-9. Pairwise multiple comparison of cost of instruction by discipline within Carnegie classification based on the Bonferroni procedure at the 5 percent level of significance: 1998 Delaware Study

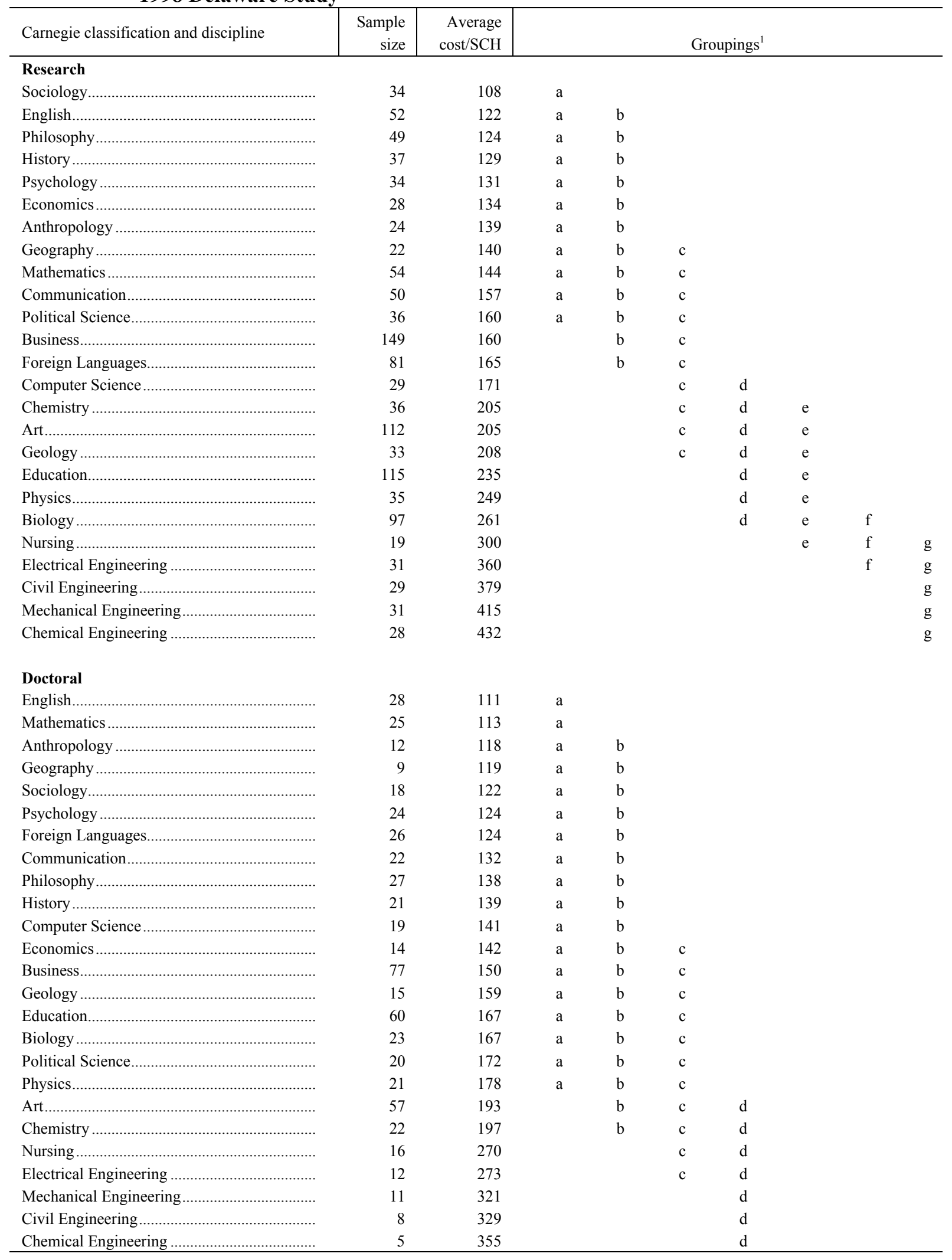

See notes at the end of the table. 
Table D-9. Pairwise multiple comparison of cost of instruction by discipline within Carnegie classification based on the Bonferroni procedure at the 5 percent level of significance: 1998 Delaware Study-Continued

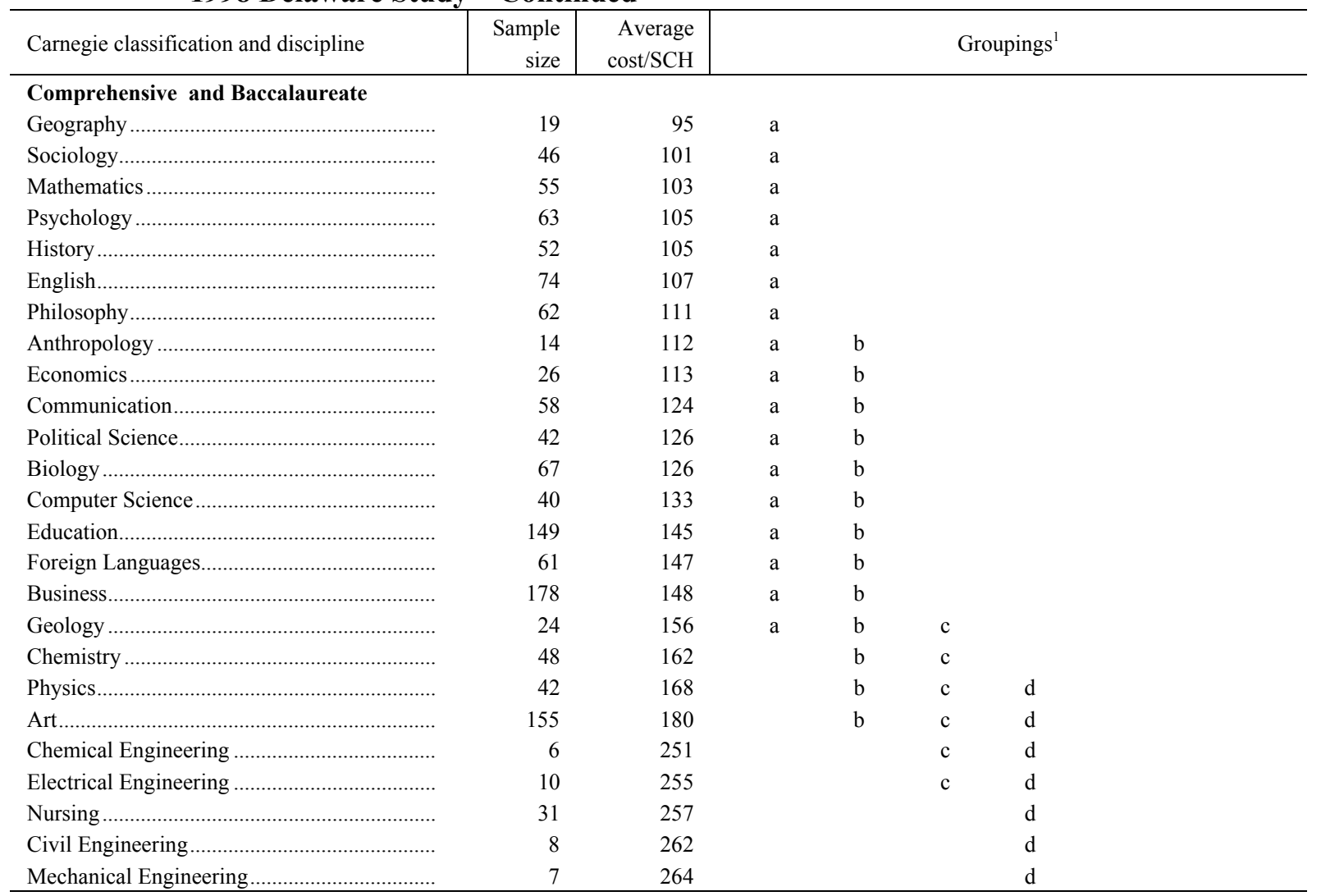

${ }^{1}$ Disciplines that are assigned the same letter are not different from each other with respect to instructional cost. It is possible for a discipline to be in more than one group.

SOURCE: University of Delaware, The Delaware Study of Instructional Costs and Productivity, 1998-2001. 
Table D-10. Pairwise multiple comparison of cost of instruction by discipline within highest degree offered based on the Bonferroni procedure at the 5 percent level of significance: 2001 Delaware Study

\begin{tabular}{|c|c|c|c|c|c|c|c|c|c|}
\hline Highest degree offered and discipline & $\begin{array}{r}\text { Sample } \\
\text { size }\end{array}$ & $\begin{array}{c}\text { Average } \\
\text { cost } / \mathrm{SCH}\end{array}$ & \multicolumn{7}{|c|}{ Groupings $^{1}$} \\
\hline \multicolumn{10}{|l|}{ Doctor's } \\
\hline 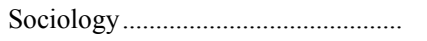 & 33 & 132 & $\mathrm{a}$ & & & & & & \\
\hline 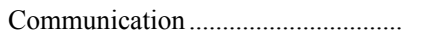 & 17 & 135 & $\mathrm{a}$ & & & & & & \\
\hline 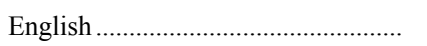 & 47 & 140 & $\mathrm{a}$ & & & & & & \\
\hline 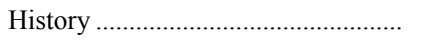 & 41 & 146 & $\mathrm{a}$ & & & & & & \\
\hline 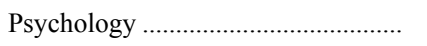 & 63 & 150 & $\mathrm{a}$ & & & & & & \\
\hline 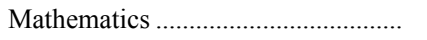 & 66 & 151 & $\mathrm{a}$ & & & & & & \\
\hline 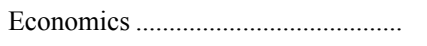 & 28 & 153 & $\mathrm{a}$ & & & & & & \\
\hline 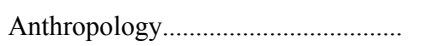 & 19 & 154 & $\mathrm{a}$ & & & & & & \\
\hline 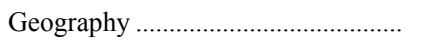 & 18 & 166 & $\mathrm{a}$ & $\mathrm{b}$ & & & & & \\
\hline 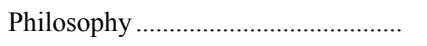 & 31 & 167 & $\mathrm{a}$ & $\mathrm{b}$ & & & & & \\
\hline 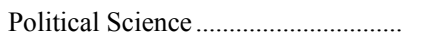 & 27 & 172 & $\mathrm{a}$ & $\mathrm{b}$ & & & & & \\
\hline 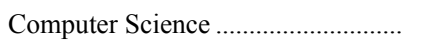 & 44 & 182 & $\mathrm{a}$ & $\mathrm{b}$ & & & & & \\
\hline 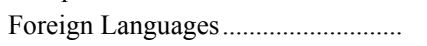 & 45 & 184 & $\mathrm{a}$ & $\mathrm{b}$ & & & & & \\
\hline 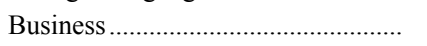 & 59 & 188 & $\mathrm{a}$ & $\mathrm{b}$ & & & & & \\
\hline 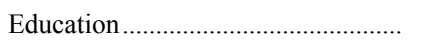 & 151 & 250 & & $\mathrm{~b}$ & $\mathrm{c}$ & & & & \\
\hline 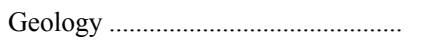 & 33 & 253 & & $\mathrm{~b}$ & $\mathrm{c}$ & $\mathrm{d}$ & & & \\
\hline 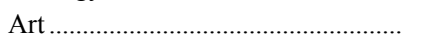 & 44 & 253 & & $\mathrm{~b}$ & $\mathrm{c}$ & $\mathrm{d}$ & & & \\
\hline 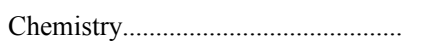 & 55 & 256 & & $\mathrm{~b}$ & $\mathrm{c}$ & $\mathrm{d}$ & & & \\
\hline 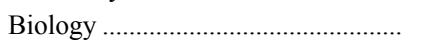 & 104 & 266 & & & $\mathrm{c}$ & $\mathrm{d}$ & & & \\
\hline 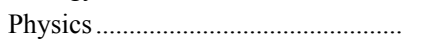 & 42 & 266 & & & $\mathrm{c}$ & $\mathrm{d}$ & & & \\
\hline 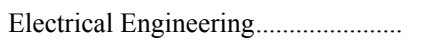 & 39 & 327 & & & & $\mathrm{~d}$ & $\mathrm{e}$ & & \\
\hline Mechanical Engineering ....................... & 38 & 358 & & & & $\mathrm{~d}$ & $\mathrm{e}$ & & \\
\hline 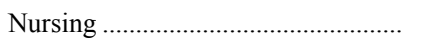 & 10 & 399 & & & & & $\mathrm{e}$ & & \\
\hline 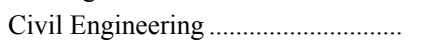 & 33 & 423 & & & & & $\mathrm{e}$ & & \\
\hline 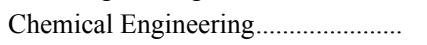 & 30 & 487 & & & & & $\mathrm{e}$ & & \\
\hline \multicolumn{10}{|l|}{ Master's } \\
\hline 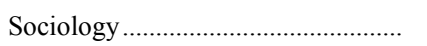 & 29 & 101 & $\mathrm{a}$ & & & & & & \\
\hline 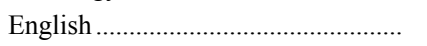 & 70 & 111 & $\mathrm{a}$ & $\mathrm{b}$ & & & & & \\
\hline 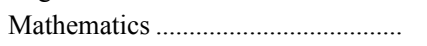 & 47 & 112 & $\mathrm{a}$ & $\mathrm{b}$ & $\mathrm{c}$ & & & & \\
\hline 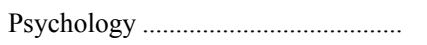 & 40 & 113 & $\mathrm{a}$ & $\mathrm{b}$ & $\mathrm{c}$ & & & & \\
\hline 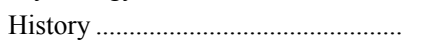 & 47 & 115 & $\mathrm{a}$ & $\mathrm{b}$ & $\mathrm{c}$ & & & & \\
\hline 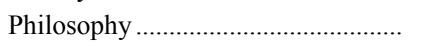 & 23 & 120 & $\mathrm{a}$ & $\mathrm{b}$ & $\mathrm{c}$ & $\mathrm{d}$ & & & \\
\hline 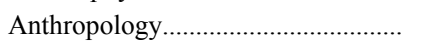 & 14 & 133 & $\mathrm{a}$ & $\mathrm{b}$ & $\mathrm{c}$ & $\mathrm{d}$ & & & \\
\hline 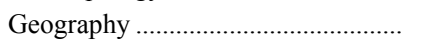 & 18 & 140 & $\mathrm{a}$ & $\mathrm{b}$ & $\mathrm{c}$ & $\mathrm{d}$ & & & \\
\hline 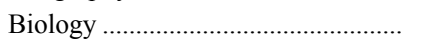 & 45 & 145 & $\mathrm{a}$ & $\mathrm{b}$ & $\mathrm{c}$ & $\mathrm{d}$ & & & \\
\hline 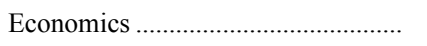 & 23 & 146 & $\mathrm{a}$ & $\mathrm{b}$ & $\mathrm{c}$ & $\mathrm{d}$ & & & \\
\hline 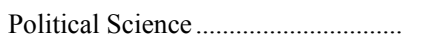 & 32 & 148 & $\mathrm{a}$ & $\mathrm{b}$ & $\mathrm{c}$ & $\mathrm{d}$ & & & \\
\hline 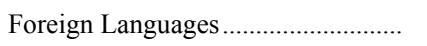 & 51 & 149 & $\mathrm{a}$ & $\mathrm{b}$ & $\mathrm{c}$ & $\mathrm{d}$ & & & \\
\hline 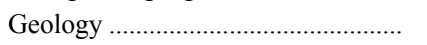 & 21 & 150 & $\mathrm{a}$ & $\mathrm{b}$ & $\mathrm{c}$ & $\mathrm{d}$ & & & \\
\hline Computer Science & 31 & 154 & & $\mathrm{~b}$ & $\mathrm{c}$ & $\mathrm{d}$ & & & \\
\hline 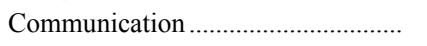 & 59 & 158 & & & $\mathrm{c}$ & $\mathrm{d}$ & & & \\
\hline 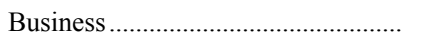 & 201 & 159 & & & & $\mathrm{~d}$ & & & \\
\hline 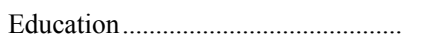 & 172 & 166 & & & & $\mathrm{~d}$ & & & \\
\hline 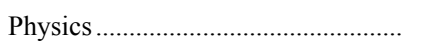 & 24 & 174 & & & & $\mathrm{~d}$ & $\mathrm{e}$ & & \\
\hline 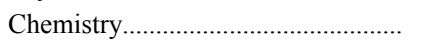 & 29 & 182 & & & & $\mathrm{~d}$ & $\mathrm{e}$ & $\mathrm{f}$ & \\
\hline Art & 145 & 213 & & & & & $\mathrm{e}$ & $\mathrm{f}$ & \\
\hline Mechanical Engineering ....................... & 11 & 296 & & & & & $\mathrm{e}$ & $\mathrm{f}$ & $\mathrm{g}$ \\
\hline 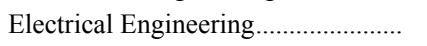 & 10 & 313 & & & & & $\mathrm{e}$ & $\mathrm{f}$ & $\mathrm{g}$ \\
\hline 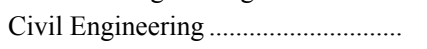 & 12 & 314 & & & & & & $\mathrm{f}$ & $\mathrm{g}$ \\
\hline 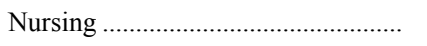 & 49 & 321 & & & & & & & $\mathrm{~g}$ \\
\hline Chemical Engineering........................ & 6 & 472 & & & & & & & $\mathrm{~g}$ \\
\hline
\end{tabular}

See notes at the end of the table. 
Table D-10. Pairwise multiple comparison of cost of instruction by discipline within highest degree offered based on the Bonferroni procedure at the 5 percent level of significance: 2001 Delaware Study-Continued

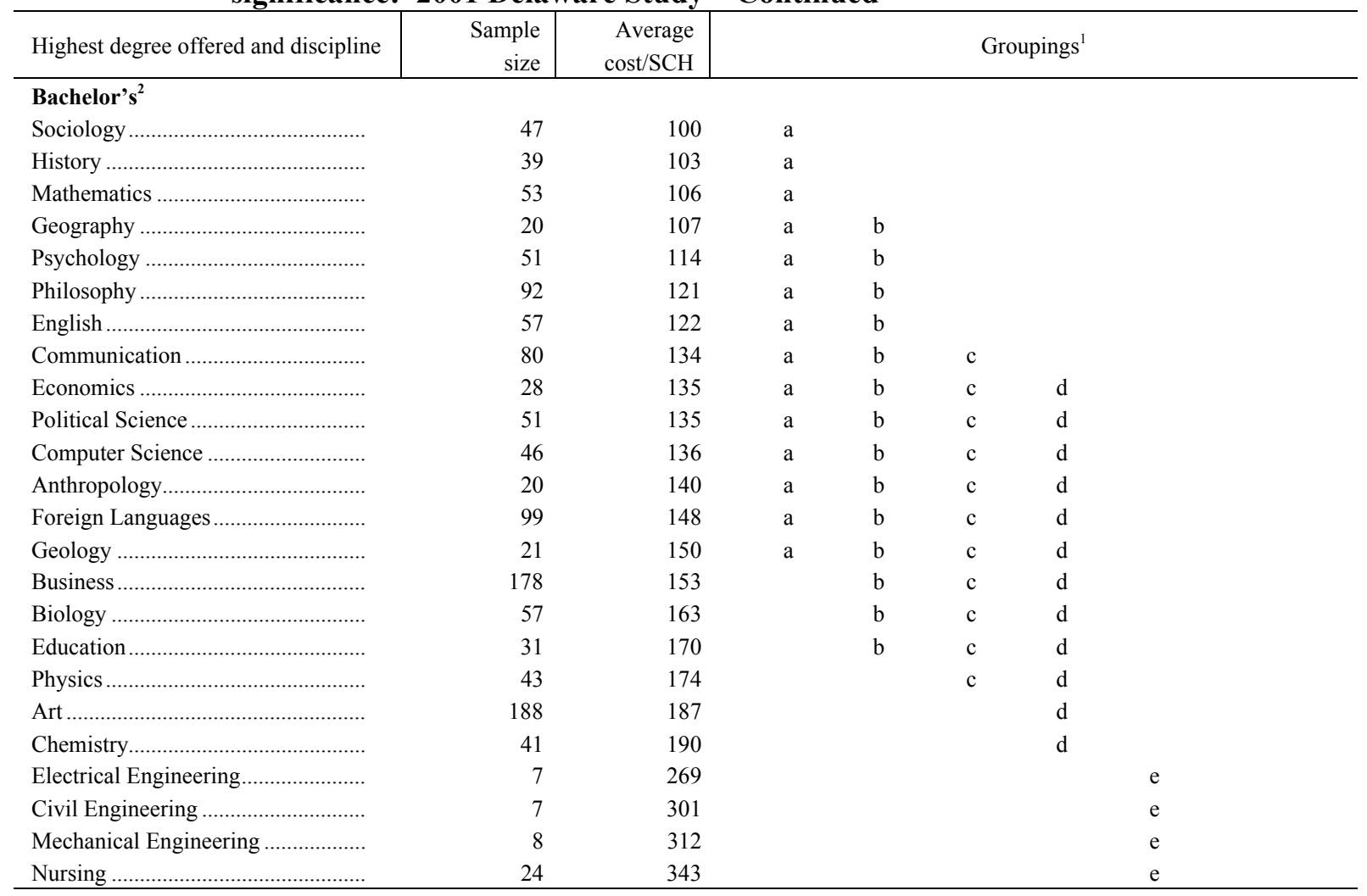

${ }^{1}$ Disciplines that are assigned the same letter are not different from each other with respect to instructional cost. It is possible for a discipline to be in more than one group.

${ }^{2}$ Chemical Engineering is not included in the analysis since it has only 1 data point.

SOURCE: University of Delaware, The Delaware Study of Instructional Costs and Productivity, 1998-2001. 
Table D-11. Pairwise multiple comparison of cost of instruction by discipline within highest degree offered based on the Bonferroni procedure at the 5 percent level of significance: 2000 Delaware Study

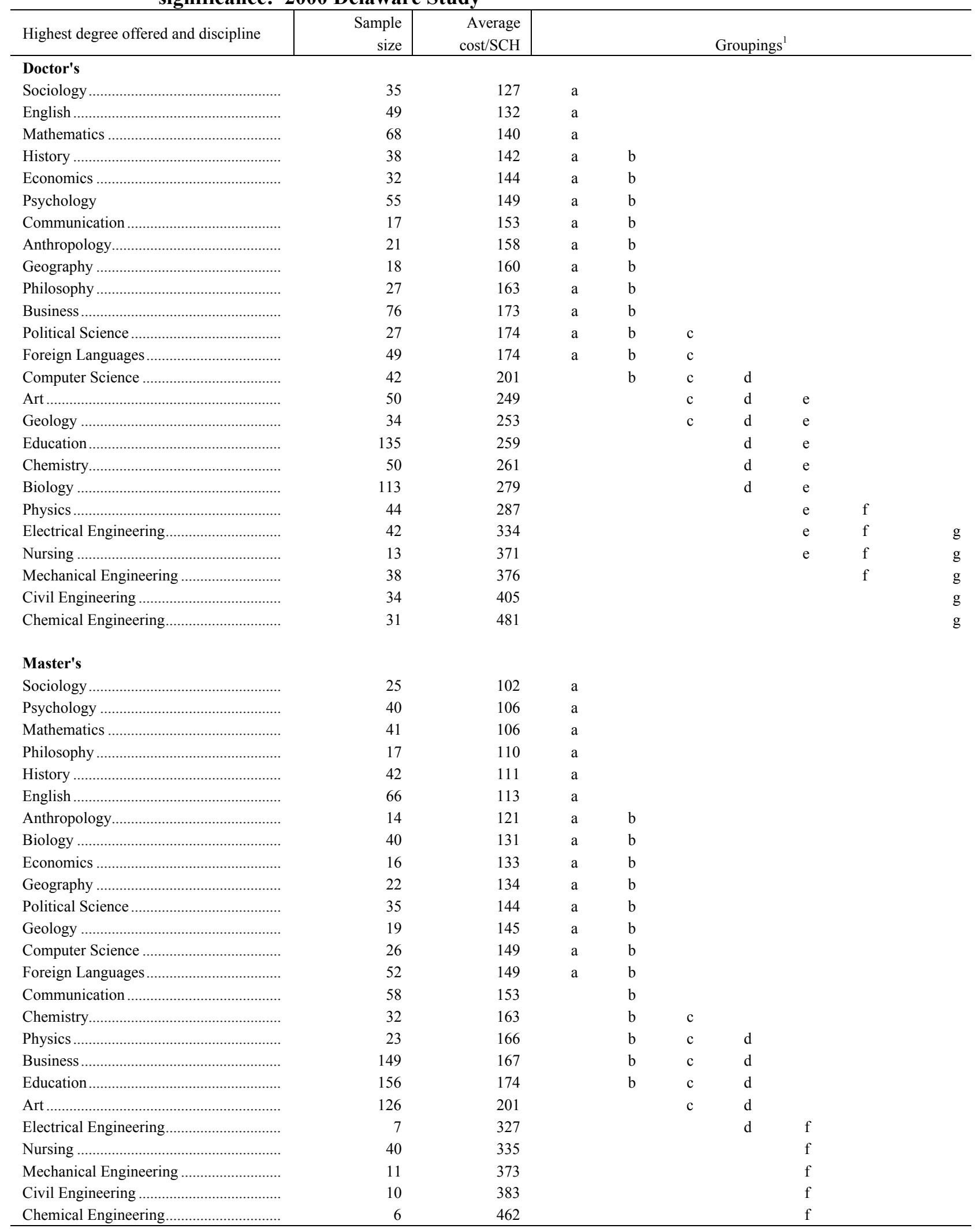

See notes at the end of the table. 
Table D-11. Pairwise multiple comparison of cost of instruction by discipline within highest degree offered based on the Bonferroni procedure at the 5 percent level of significance: 2000 Delaware Study-Continued

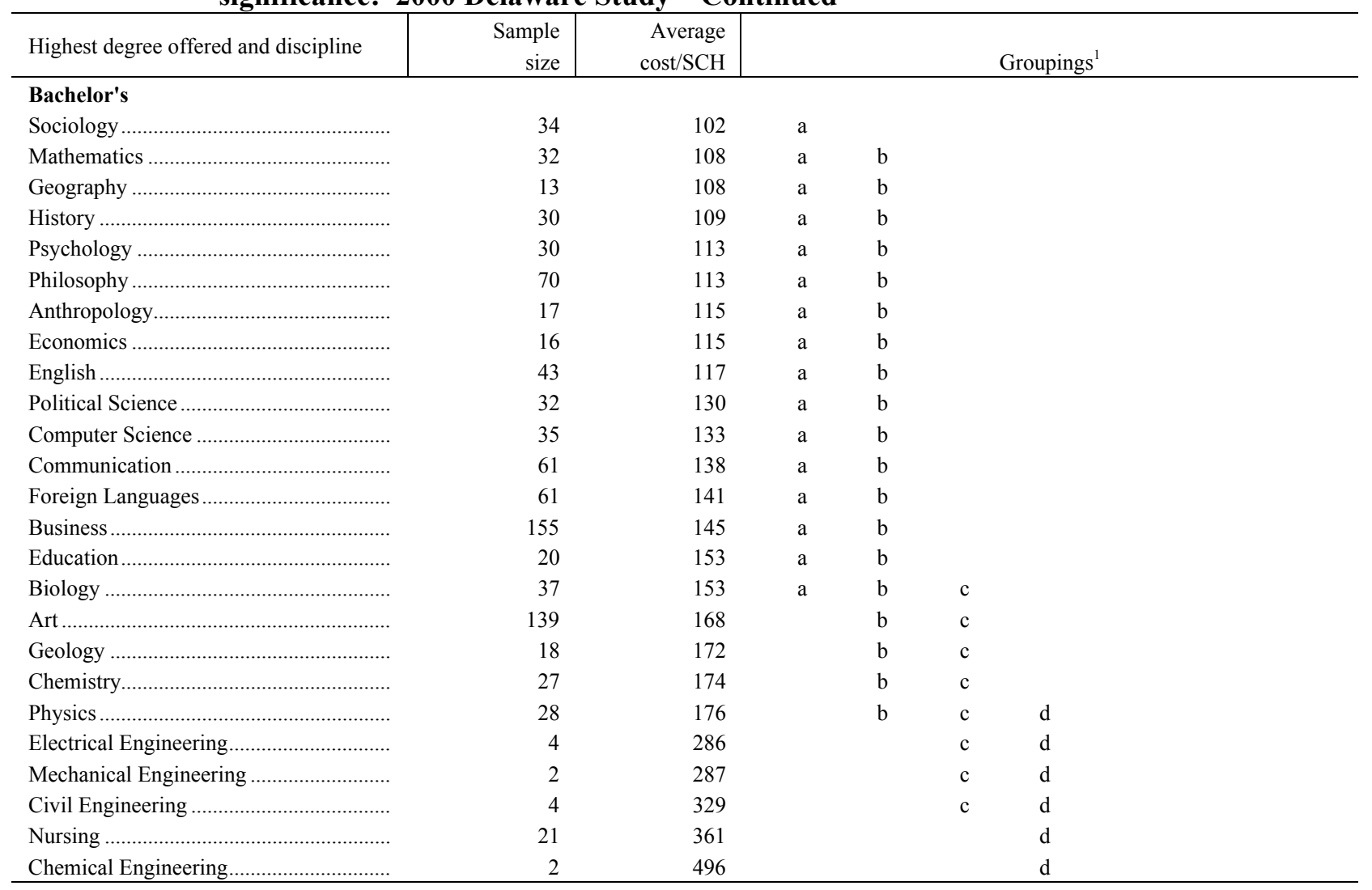

${ }^{1}$ Disciplines that are assigned the same letter are not different from each other with respect to instructional cost. It is possible for a discipline to be in more than one group.

SOURCE: University of Delaware, The Delaware Study of Instructional Costs and Productivity, 1998-2001. 
Table D-12. Pairwise multiple comparison of cost of instruction by discipline within highest degree offered based on the Bonferroni procedure at the 5 percent level of significance: 1998 Delaware Study

\begin{tabular}{|c|c|c|c|c|c|c|c|c|c|}
\hline Highest degree offered and discipline & $\begin{array}{r}\text { Sample } \\
\text { size }\end{array}$ & $\begin{array}{r}\text { Average } \\
\text { cost } / \mathrm{SCH}\end{array}$ & \multicolumn{7}{|c|}{ Groupings ${ }^{1}$} \\
\hline \multicolumn{10}{|l|}{ Doctor's } \\
\hline Sociology & 31 & 115 & $\mathrm{a}$ & & & & & & \\
\hline 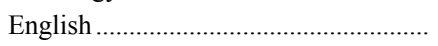 & 44 & 128 & $\mathrm{a}$ & & & & & & \\
\hline Economics & 29 & 134 & $\mathrm{a}$ & & & & & & \\
\hline 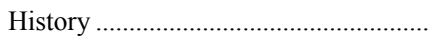 & 34 & 136 & $\mathrm{a}$ & & & & & & \\
\hline Communication & 16 & 138 & $\mathrm{a}$ & $\mathrm{b}$ & & & & & \\
\hline 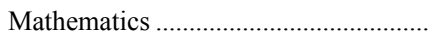 & 61 & 145 & $\mathrm{a}$ & $\mathrm{b}$ & & & & & \\
\hline 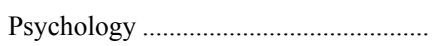 & 52 & 149 & $\mathrm{a}$ & $\mathrm{b}$ & & & & & \\
\hline Business & 78 & 152 & $\mathrm{a}$ & $\mathrm{b}$ & & & & & \\
\hline Computer Science & 29 & 170 & $\mathrm{a}$ & $\mathrm{b}$ & $\mathrm{c}$ & & & & \\
\hline 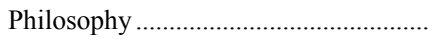 & 30 & 172 & a & $\mathrm{b}$ & $\mathrm{c}$ & & & & \\
\hline 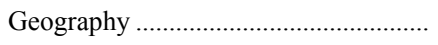 & 15 & 174 & $\mathrm{a}$ & $\mathrm{b}$ & $\mathrm{c}$ & $\mathrm{d}$ & & & \\
\hline 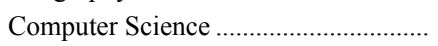 & 28 & 176 & $\mathrm{a}$ & $\mathrm{b}$ & $\mathrm{c}$ & $\mathrm{d}$ & & & \\
\hline 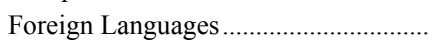 & 38 & 177 & $\mathrm{a}$ & $\mathrm{b}$ & $\mathrm{c}$ & $\mathrm{d}$ & & & \\
\hline 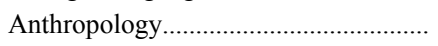 & 19 & 192 & $\mathrm{a}$ & $\mathrm{b}$ & $\mathrm{c}$ & $\mathrm{d}$ & & & \\
\hline 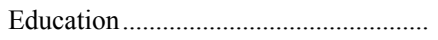 & 137 & 204 & & $\mathrm{~b}$ & $\mathrm{c}$ & $\mathrm{d}$ & & & \\
\hline 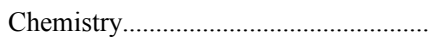 & 47 & 208 & & $\mathrm{~b}$ & $\mathrm{c}$ & $\mathrm{d}$ & & & \\
\hline 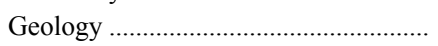 & 25 & 231 & & $\mathrm{~b}$ & $\mathrm{c}$ & $\mathrm{d}$ & $\mathrm{e}$ & & \\
\hline 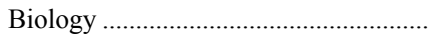 & 100 & 242 & & & $\mathrm{c}$ & $\mathrm{d}$ & $\mathrm{e}$ & & \\
\hline 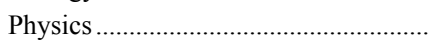 & 40 & 249 & & & $\mathrm{c}$ & $\mathrm{d}$ & $\mathrm{e}$ & & \\
\hline Art & 40 & 262 & & & & $\mathrm{~d}$ & $\mathrm{e}$ & $\mathrm{f}$ & \\
\hline 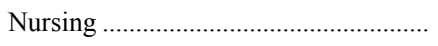 & 12 & 292 & & & & $\mathrm{~d}$ & $\mathrm{e}$ & $\mathrm{f}$ & $\mathrm{g}$ \\
\hline Electrical Engineering ................................ & 43 & 342 & & & & & $\mathrm{e}$ & $\mathrm{f}$ & $\mathrm{g}$ \\
\hline 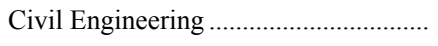 & 33 & 361 & & & & & & $\mathrm{f}$ & g \\
\hline Mechanical Engineering ........................... & 39 & 413 & & & & & & & $\mathrm{~g}$ \\
\hline Chemical Engineering ............................... & 31 & 423 & & & & & & & $\mathrm{~g}$ \\
\hline \multicolumn{10}{|l|}{ Master's } \\
\hline 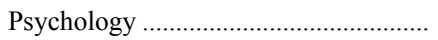 & 34 & 88 & $\mathrm{a}$ & & & & & & \\
\hline 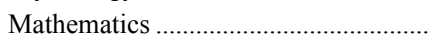 & 36 & 95 & $\mathrm{a}$ & $\mathrm{b}$ & & & & & \\
\hline Sociology & 25 & 95 & $\mathrm{a}$ & $\mathrm{b}$ & $\mathrm{c}$ & & & & \\
\hline 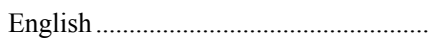 & 57 & 101 & $\mathrm{a}$ & $\mathrm{b}$ & $\mathrm{c}$ & & & & \\
\hline Geography & 19 & 110 & $\mathrm{a}$ & $\mathrm{b}$ & $\mathrm{c}$ & $\mathrm{d}$ & & & \\
\hline 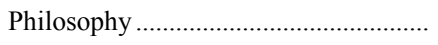 & 21 & 114 & $\mathrm{a}$ & $\mathrm{b}$ & $\mathrm{c}$ & $\mathrm{d}$ & & & \\
\hline 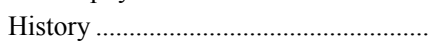 & 37 & 115 & $\mathrm{a}$ & $\mathrm{b}$ & $\mathrm{c}$ & $\mathrm{d}$ & & & \\
\hline 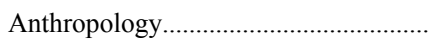 & 16 & 119 & $\mathrm{a}$ & $\mathrm{b}$ & $\mathrm{c}$ & $\mathrm{d}$ & & & \\
\hline 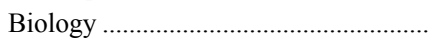 & 40 & 125 & $\mathrm{a}$ & $\mathrm{b}$ & $\mathrm{c}$ & $\mathrm{d}$ & & & \\
\hline Computer Science …................................. & 29 & 131 & $\mathrm{a}$ & $\mathrm{b}$ & $\mathrm{c}$ & $\mathrm{d}$ & & & \\
\hline Economics & 17 & 133 & $\mathrm{a}$ & $\mathrm{b}$ & $\mathrm{c}$ & $\mathrm{d}$ & $\mathrm{e}$ & & \\
\hline 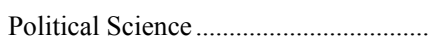 & 34 & 133 & & $\mathrm{~b}$ & $\mathrm{c}$ & $\mathrm{d}$ & $\mathrm{e}$ & & \\
\hline Communication & 55 & 137 & & & $\mathrm{c}$ & $\mathrm{d}$ & $\mathrm{e}$ & & \\
\hline 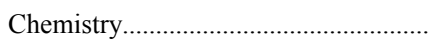 & 30 & 141 & & & $\mathrm{c}$ & $\mathrm{d}$ & $\mathrm{e}$ & & \\
\hline Foreign Languages & 44 & 143 & & & $\mathrm{c}$ & $\mathrm{d}$ & $\mathrm{e}$ & & \\
\hline Education & 141 & 145 & & & & $\mathrm{~d}$ & $\mathrm{e}$ & & \\
\hline Geology & 24 & 153 & & & & $\mathrm{~d}$ & $\mathrm{e}$ & & \\
\hline 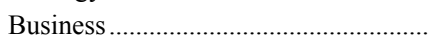 & 137 & 157 & & & & $\mathrm{~d}$ & $\mathrm{e}$ & & \\
\hline 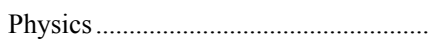 & 20 & 160 & & & & $\mathrm{~d}$ & $\mathrm{e}$ & $\mathrm{f}$ & \\
\hline Art & 130 & 192 & & & & & $\mathrm{e}$ & $\mathrm{f}$ & \\
\hline Electrical Engineering ................................. & 6 & 255 & & & & & $\mathrm{e}$ & $\mathrm{f}$ & $\mathrm{g}$ \\
\hline 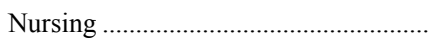 & 33 & 261 & & & & & & $\mathrm{f}$ & $\mathrm{g}$ \\
\hline 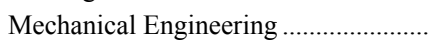 & 10 & 285 & & & & & & f & $\mathrm{g}$ \\
\hline Chemical Engineering............................... & 7 & 291 & & & & & & $\mathrm{f}$ & $\mathrm{g}$ \\
\hline Civil Engineering ................................... & 9 & 347 & & & & & & & $\mathrm{~g}$ \\
\hline
\end{tabular}

See notes at the end of the table. 
Table D-12. Pairwise multiple comparison of cost of instruction by discipline within highest degree offered based on the Bonferroni procedure at the 5 percent level of significance: 1998 Delaware Study-Continued

\begin{tabular}{|c|c|c|c|c|c|}
\hline Highest degree offered and discipline & $\begin{array}{r}\text { Sample } \\
\text { size }\end{array}$ & $\begin{array}{r}\text { Average } \\
\text { cost/SCH }\end{array}$ & & & Groupings $^{1}$ \\
\hline \multicolumn{6}{|l|}{ Bachelor's } \\
\hline 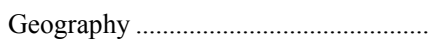 & 14 & 90 & $\mathrm{a}$ & & \\
\hline 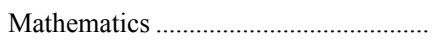 & 35 & 104 & $\mathrm{a}$ & & \\
\hline 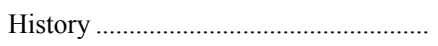 & 37 & 106 & $\mathrm{a}$ & & \\
\hline 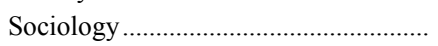 & 39 & 107 & a & & \\
\hline 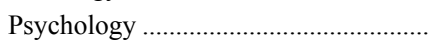 & 36 & 109 & $\mathrm{a}$ & & \\
\hline 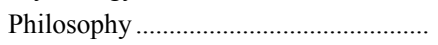 & 70 & 113 & $\mathrm{a}$ & & \\
\hline 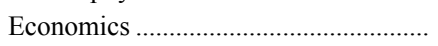 & 20 & 116 & a & $\mathrm{b}$ & \\
\hline 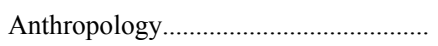 & 14 & 118 & $\mathrm{a}$ & $\mathrm{b}$ & \\
\hline 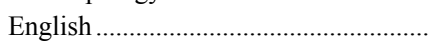 & 47 & 120 & a & $\mathrm{b}$ & \\
\hline 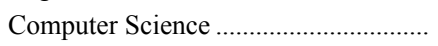 & 29 & 129 & $\mathrm{a}$ & $\mathrm{b}$ & \\
\hline Communication & 56 & 139 & $\mathrm{a}$ & $\mathrm{b}$ & \\
\hline 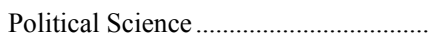 & 32 & 140 & $\mathrm{a}$ & $\mathrm{b}$ & \\
\hline 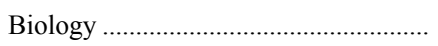 & 42 & 141 & a & $\mathrm{b}$ & \\
\hline 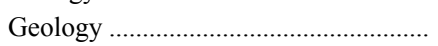 & 20 & 143 & a & $\mathrm{b}$ & \\
\hline 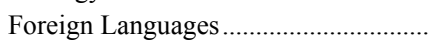 & 76 & 147 & $\mathrm{a}$ & $\mathrm{b}$ & \\
\hline 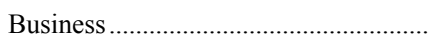 & 168 & 150 & $\mathrm{a}$ & $\mathrm{b}$ & \\
\hline 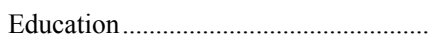 & 24 & 157 & $\mathrm{a}$ & $\mathrm{b}$ & \\
\hline 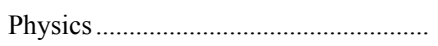 & 31 & 172 & & $\mathrm{~b}$ & \\
\hline 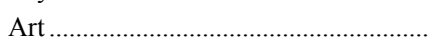 & 136 & 177 & & $\mathrm{~b}$ & \\
\hline 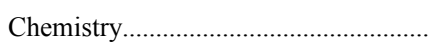 & 28 & 178 & & $\mathrm{~b}$ & $\mathrm{c}$ \\
\hline 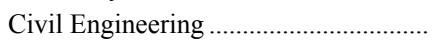 & 4 & 214 & & $\mathrm{~b}$ & $\mathrm{c}$ \\
\hline Mechanical Engineering ........................... & 2 & 258 & & $\mathrm{~b}$ & $\mathrm{c}$ \\
\hline 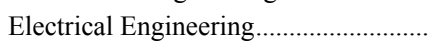 & 5 & 274 & & $\mathrm{~b}$ & $\mathrm{c}$ \\
\hline 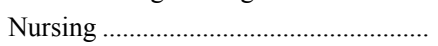 & 17 & 275 & & & $\mathrm{c}$ \\
\hline 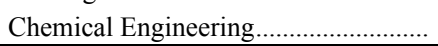 & 3 & 410 & & & $\mathrm{c}$ \\
\hline
\end{tabular}

${ }^{1}$ Disciplines that are assigned the same letter are not different from each other with respect to instructional cost. It is possible for a discipline to be in more than one group.

SOURCE: University of Delaware, The Delaware Study of Instructional Costs and Productivity, 1998-2001. 
Table D-13. Pairwise multiple comparison of cost of instruction by discipline within undergraduate/graduate program mix based on the Bonferroni procedure at the 5 percent level of significance: 2001 Delaware Study

\begin{tabular}{|c|c|c|c|c|c|c|c|c|c|c|}
\hline \multirow{2}{*}{$\begin{array}{l}\text { Program } \text { mix }^{1} \text { and discipline } \\
\text { Undergraduate degree: } \mathbf{7 5 - 1 0 0 \%}\end{array}$} & $\begin{array}{r}\text { Sample } \\
\text { size } \\
\end{array}$ & $\begin{array}{r}\text { Average } \\
\text { cost } / \mathrm{SCH} \\
\end{array}$ & \multicolumn{8}{|c|}{ Groupings $^{2}$} \\
\hline & & & & & & & & & & \\
\hline Sociology & 100 & 108 & $\mathrm{a}$ & & & & & & & \\
\hline 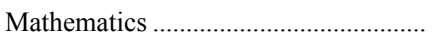 & 78 & 113 & $\mathrm{a}$ & $\mathrm{b}$ & & & & & & \\
\hline 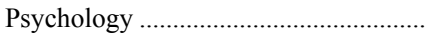 & 128 & 121 & $\mathrm{a}$ & $\mathrm{b}$ & $\mathrm{c}$ & & & & & \\
\hline 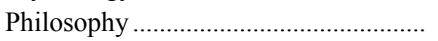 & 107 & 123 & $\mathrm{a}$ & $\mathrm{b}$ & $\mathrm{c}$ & & & & & \\
\hline 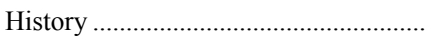 & 107 & 124 & $\mathrm{a}$ & $\mathrm{b}$ & $\mathrm{c}$ & & & & & \\
\hline 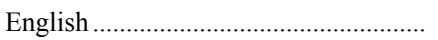 & 123 & 126 & $\mathrm{a}$ & $\mathrm{b}$ & $\mathrm{c}$ & & & & & \\
\hline 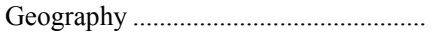 & 36 & 130 & $\mathrm{a}$ & $\mathrm{b}$ & $\mathrm{c}$ & $\mathrm{d}$ & & & & \\
\hline 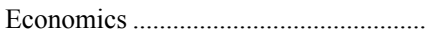 & 52 & 137 & $\mathrm{a}$ & $\mathrm{b}$ & $\mathrm{c}$ & $\mathrm{d}$ & $\mathrm{e}$ & & & \\
\hline 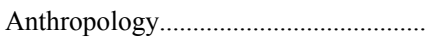 & 43 & 140 & $\mathrm{a}$ & $\mathrm{b}$ & $\mathrm{c}$ & $\mathrm{d}$ & $\mathrm{e}$ & & & \\
\hline 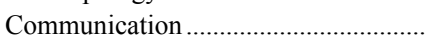 & 148 & 142 & & $\mathrm{~b}$ & $\mathrm{c}$ & $\mathrm{d}$ & e & & & \\
\hline 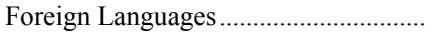 & 137 & 146 & & & $\mathrm{c}$ & $\mathrm{d}$ & $\mathrm{e}$ & & & \\
\hline 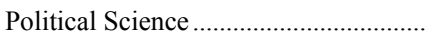 & 90 & 147 & & & $\mathrm{c}$ & $\mathrm{d}$ & $\mathrm{e}$ & & & \\
\hline 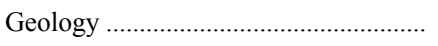 & 27 & 147 & & & $\mathrm{c}$ & $\mathrm{d}$ & $\mathrm{e}$ & $\mathrm{f}$ & & \\
\hline Computer Science & 61 & 151 & & & $\mathrm{c}$ & $\mathrm{d}$ & e & $\mathrm{f}$ & & \\
\hline Education & 79 & 152 & & & $\mathrm{c}$ & $\mathrm{d}$ & $\mathrm{e}$ & $\mathrm{f}$ & & \\
\hline 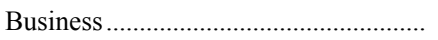 & 311 & 157 & & & & $\mathrm{~d}$ & $\mathrm{e}$ & $\mathrm{f}$ & & \\
\hline 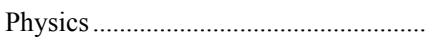 & 48 & 174 & & & & $\mathrm{~d}$ & $\mathrm{e}$ & $\mathrm{f}$ & & \\
\hline 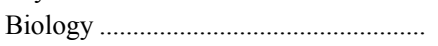 & 160 & 186 & & & & & e & $\mathrm{f}$ & & \\
\hline Art & 285 & 190 & & & & & & $\mathrm{f}$ & & \\
\hline 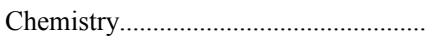 & 66 & 196 & & & & & & $\mathrm{f}$ & & \\
\hline 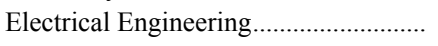 & 16 & 282 & & & & & & & $\mathrm{~g}$ & \\
\hline Mechanical Engineering ............................ & 37 & 337 & & & & & & & $\mathrm{~g}$ & \\
\hline 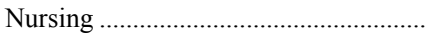 & 59 & 338 & & & & & & & $\mathrm{~g}$ & \\
\hline 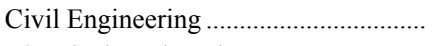 & 24 & 339 & & & & & & & $\mathrm{~g}$ & \\
\hline Chemical Engineering ................................ & 22 & 449 & & & & & & & $\mathrm{~g}$ & \\
\hline \multicolumn{11}{|l|}{ Undergraduate degree: $0-75 \%$} \\
\hline 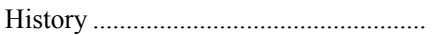 & 22 & 117 & $\mathrm{a}$ & & & & & & & \\
\hline Sociology & 8 & 130 & $\mathrm{a}$ & & & & & & & \\
\hline 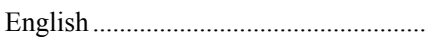 & 49 & 132 & $\mathrm{a}$ & & & & & & & \\
\hline Political Science & 20 & 149 & $\mathrm{a}$ & $\mathrm{b}$ & & & & & & \\
\hline 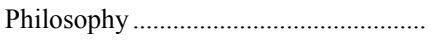 & 38 & 153 & $\mathrm{a}$ & $\mathrm{b}$ & & & & & & \\
\hline 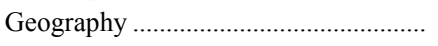 & 21 & 154 & $\mathrm{a}$ & $\mathrm{b}$ & $\mathrm{c}$ & & & & & \\
\hline 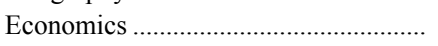 & 25 & 155 & $\mathrm{a}$ & $\mathrm{b}$ & $\mathrm{c}$ & & & & & \\
\hline 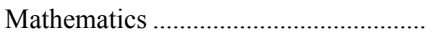 & 88 & 168 & $\mathrm{a}$ & $\mathrm{b}$ & $\mathrm{c}$ & & & & & \\
\hline 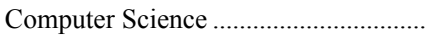 & 60 & 169 & $\mathrm{a}$ & $\mathrm{b}$ & $\mathrm{c}$ & & & & & \\
\hline 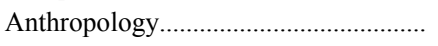 & 11 & 169 & $\mathrm{a}$ & $\mathrm{b}$ & $\mathrm{c}$ & $\mathrm{d}$ & & & & \\
\hline 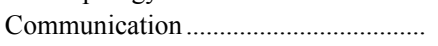 & 8 & 175 & $\mathrm{a}$ & $\mathrm{b}$ & $\mathrm{c}$ & $\mathrm{d}$ & & & & \\
\hline 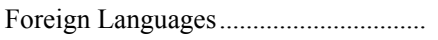 & 58 & 183 & $\mathrm{a}$ & $\mathrm{b}$ & $\mathrm{c}$ & $\mathrm{d}$ & & & & \\
\hline Business & 128 & 186 & $\mathrm{a}$ & $\mathrm{b}$ & $\mathrm{c}$ & $\mathrm{d}$ & & & & \\
\hline 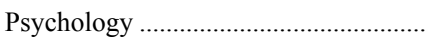 & 26 & 187 & $\mathrm{a}$ & $\mathrm{b}$ & $\mathrm{c}$ & $\mathrm{d}$ & & & & \\
\hline 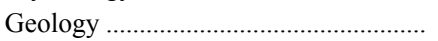 & 47 & 215 & & $\mathrm{~b}$ & $\mathrm{c}$ & $\mathrm{d}$ & $\mathrm{e}$ & & & \\
\hline Education & 283 & 236 & & & $\mathrm{c}$ & $\mathrm{d}$ & $\mathrm{e}$ & $\mathrm{f}$ & & \\
\hline 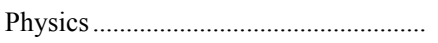 & 60 & 236 & & & $\mathrm{c}$ & $\mathrm{d}$ & $\mathrm{e}$ & $\mathrm{f}$ & & \\
\hline 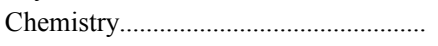 & 60 & 246 & & & & $\mathrm{~d}$ & $\mathrm{e}$ & $\mathrm{f}$ & $\mathrm{g}$ & \\
\hline 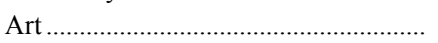 & 93 & 260 & & & & & e & $\mathrm{f}$ & $\mathrm{g}$ & \\
\hline 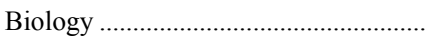 & 45 & 320 & & & & & $\mathrm{e}$ & $\mathrm{f}$ & $\mathrm{g}$ & $\mathrm{h}$ \\
\hline 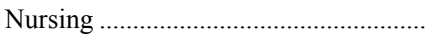 & 23 & 322 & & & & & & $\mathrm{f}$ & $\mathrm{g}$ & $\mathrm{h}$ \\
\hline 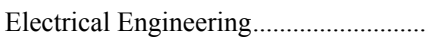 & 40 & 332 & & & & & & & $\mathrm{~g}$ & $\mathrm{~h}$ \\
\hline Mechanical Engineering ........................... & 21 & 358 & & & & & & & $\mathrm{~g}$ & $\mathrm{~h}$ \\
\hline 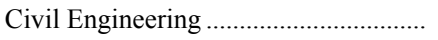 & 27 & 411 & & & & & & & & $\mathrm{~h}$ \\
\hline Chemical Engineering & 14 & 473 & & & & & & & & $\mathrm{~h}$ \\
\hline
\end{tabular}

${ }^{1}$ Based on the number of bachelor's degrees as percent of total degrees granted in discipline.

${ }^{2}$ Disciplines that are assigned the same letter are not different from each other with respect to instructional cost. It is possible for a discipline to be in more than one group.

SOURCE: University of Delaware, The Delaware Study of Instructional Costs and Productivity, 1998-2001. 
Table D-14. Pairwise multiple comparison of cost of instruction by discipline within undergraduate/graduate program mix based on the Bonferroni procedure at the 5 percent level of significance: 2000 Delaware Study

\begin{tabular}{|c|c|c|c|c|c|c|}
\hline Program mix ${ }^{1}$ and discipline & $\begin{array}{r}\text { Sample } \\
\text { size }\end{array}$ & $\begin{array}{r}\text { Average } \\
\text { cost/SCH }\end{array}$ & & Groupings $^{2}$ & & \\
\hline \multicolumn{7}{|l|}{ Undergraduate degree: $75-100 \%$} \\
\hline 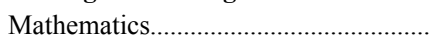 & 61 & 111 & $\mathrm{a}$ & & & \\
\hline Sociology & 87 & 112 & $\mathrm{a}$ & & & \\
\hline 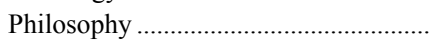 & 84 & 114 & $\mathrm{a}$ & & & \\
\hline 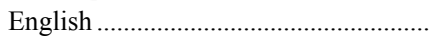 & 104 & 117 & $\mathrm{a}$ & $\mathrm{b}$ & & \\
\hline 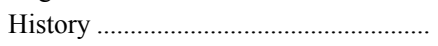 & 90 & 121 & $\mathrm{a}$ & $\mathrm{b}$ & & \\
\hline 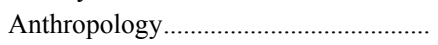 & 41 & 123 & $\mathrm{a}$ & $\mathrm{b}$ & & \\
\hline 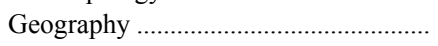 & 34 & 123 & $\mathrm{a}$ & $\mathrm{b}$ & & \\
\hline Psychology & 105 & 123 & $\mathrm{a}$ & $\mathrm{b}$ & & \\
\hline 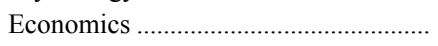 & 43 & 130 & $\mathrm{a}$ & $\mathrm{b}$ & & \\
\hline Computer Science & 46 & 142 & $\mathrm{a}$ & $\mathrm{b}$ & $\mathrm{c}$ & \\
\hline 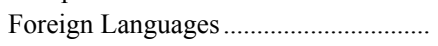 & 99 & 145 & $\mathrm{a}$ & $\mathrm{b}$ & $\mathrm{c}$ & \\
\hline 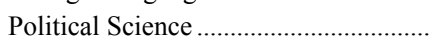 & 74 & 148 & $\mathrm{a}$ & $\mathrm{b}$ & $\mathrm{c}$ & \\
\hline Communication & 132 & 148 & $\mathrm{a}$ & $\mathrm{b}$ & $\mathrm{c}$ & \\
\hline 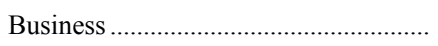 & 283 & 151 & & $\mathrm{~b}$ & $\mathrm{c}$ & \\
\hline 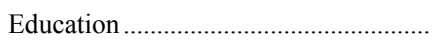 & 66 & 157 & & $\mathrm{~b}$ & $\mathrm{c}$ & \\
\hline Geology & 25 & 165 & & $\mathrm{~b}$ & $\mathrm{c}$ & \\
\hline Art & 225 & 174 & & & $\mathrm{c}$ & \\
\hline 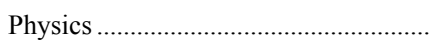 & 31 & 175 & & & $\mathrm{c}$ & \\
\hline 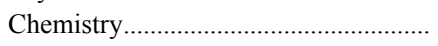 & 57 & 178 & & & $\mathrm{c}$ & \\
\hline 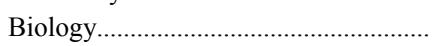 & 141 & 193 & & & $\mathrm{c}$ & \\
\hline 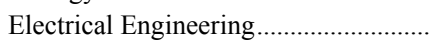 & 16 & 308 & & & & $\mathrm{~d}$ \\
\hline Mechanical Engineering ........................ & 30 & 345 & & & & $\mathrm{~d}$ \\
\hline 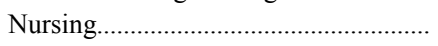 & 49 & 353 & & & & $\mathrm{~d}$ \\
\hline 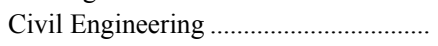 & 21 & 366 & & & & $\mathrm{~d}$ \\
\hline Chemical Engineering ................................. & 26 & 472 & & & & $\mathrm{~d}$ \\
\hline \multicolumn{7}{|l|}{ Undergraduate degree: $0-75 \%$} \\
\hline 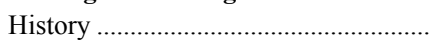 & 20 & 122 & $\mathrm{a}$ & & & \\
\hline 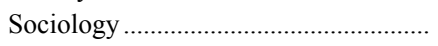 & 9 & 122 & $\mathrm{a}$ & & & \\
\hline 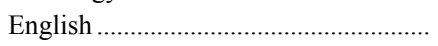 & 50 & 124 & $\mathrm{a}$ & & & \\
\hline 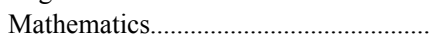 & 83 & 137 & $\mathrm{a}$ & & & \\
\hline 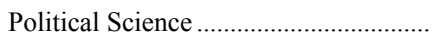 & 20 & 144 & $\mathrm{a}$ & & & \\
\hline 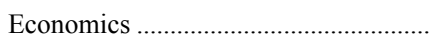 & 22 & 144 & $\mathrm{a}$ & & & \\
\hline 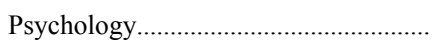 & 20 & 148 & $\mathrm{a}$ & $\mathrm{b}$ & & \\
\hline Communication & 6 & 148 & $\mathrm{a}$ & $\mathrm{b}$ & & \\
\hline 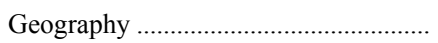 & 19 & 158 & $\mathrm{a}$ & $\mathrm{b}$ & & \\
\hline 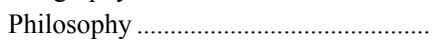 & 33 & 165 & $\mathrm{a}$ & $\mathrm{b}$ & & \\
\hline 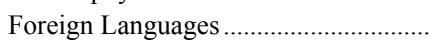 & 66 & 174 & $\mathrm{a}$ & $\mathrm{b}$ & & \\
\hline 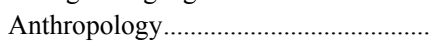 & 11 & 175 & $\mathrm{a}$ & $\mathrm{b}$ & & \\
\hline 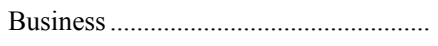 & 93 & 183 & $\mathrm{a}$ & $\mathrm{b}$ & & \\
\hline Computer Science & 57 & 192 & $\mathrm{a}$ & $\mathrm{b}$ & & \\
\hline 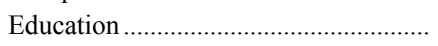 & 245 & 225 & $\mathrm{a}$ & $\mathrm{b}$ & & \\
\hline Geology & 49 & 233 & $\mathrm{a}$ & $\mathrm{b}$ & $\mathrm{c}$ & \\
\hline 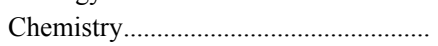 & 53 & 244 & & $\mathrm{~b}$ & $\mathrm{c}$ & \\
\hline 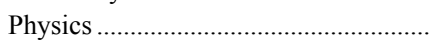 & 65 & 249 & & $\mathrm{~b}$ & $\mathrm{c}$ & \\
\hline 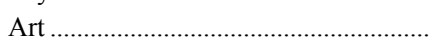 & 87 & 250 & & $\mathrm{~b}$ & $\mathrm{c}$ & \\
\hline 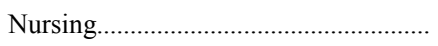 & 24 & 320 & & & $\mathrm{c}$ & \\
\hline 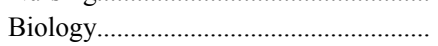 & 49 & 337 & & & $\mathrm{c}$ & $\mathrm{d}$ \\
\hline 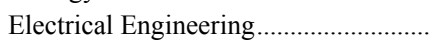 & 38 & 345 & & & & $\mathrm{~d}$ \\
\hline Mechanical Engineering ........................ & 20 & 399 & & & & $\mathrm{~d}$ \\
\hline 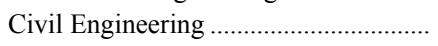 & 27 & 416 & & & & $\mathrm{~d}$ \\
\hline Chemical Engineering & 12 & 454 & & & & $\mathrm{~d}$ \\
\hline
\end{tabular}

${ }^{1}$ Based on the number of bachelor's degrees as percent of total degrees granted in discipline.

${ }^{2}$ Disciplines that are assigned the same letter are not different from each other with respect to instructional cost. It is possible for a discipline to be in more than one group.

SOURCE: University of Delaware, The Delaware Study of Instructional Costs and Productivity, 1998-2001. 
Table D-15. Pairwise multiple comparison of cost of instruction by discipline within undergraduate/graduate program mix based on the Bonferroni procedure at the 5 percent level of significance: 1998 Delaware Study

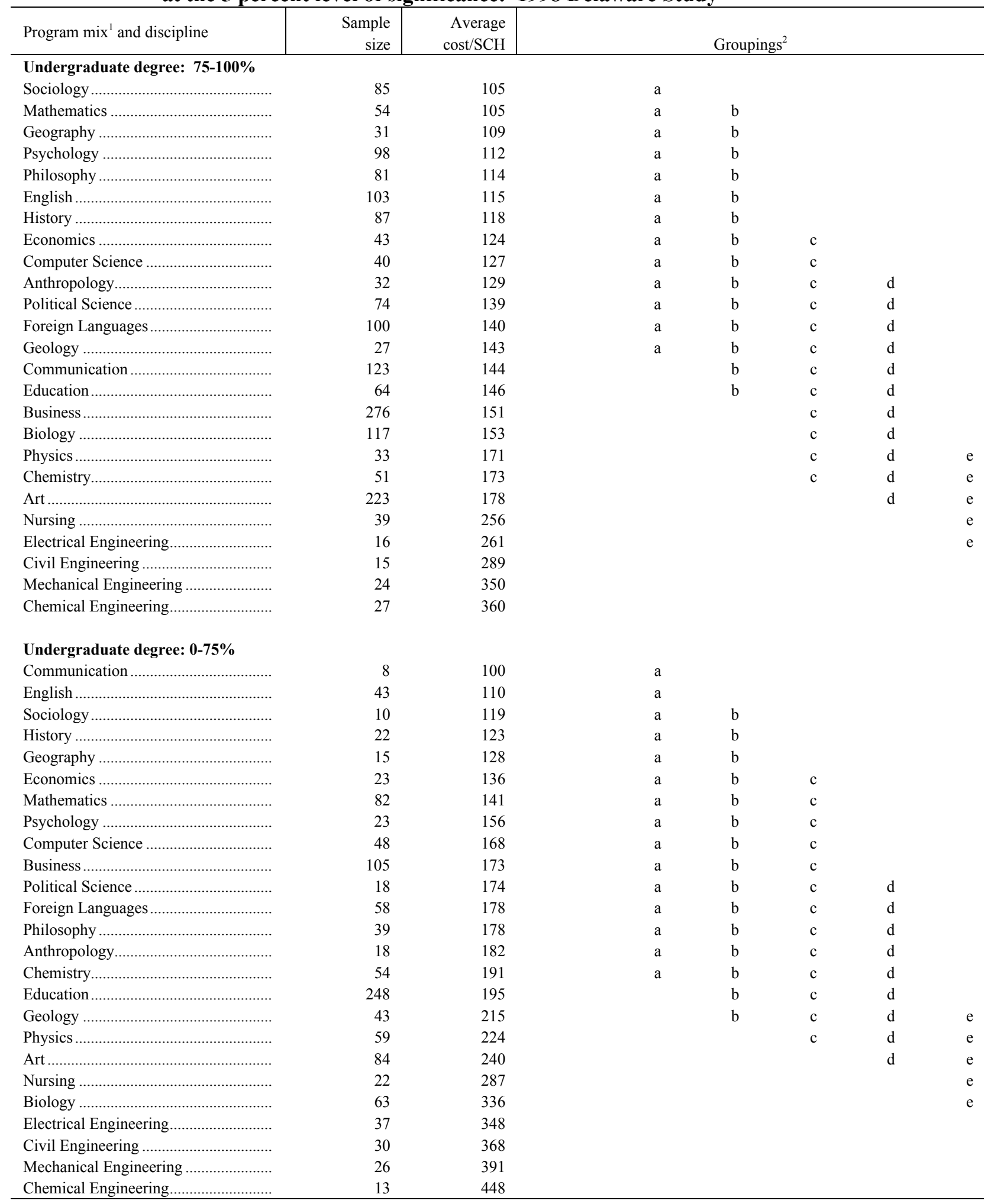

${ }^{1}$ Based on the number of bachelor's degrees as percent of total degrees granted in discipline.

${ }^{2}$ Disciplines that are assigned the same letter are not different from each other with respect to instructional cost. It is possible for a discipline to be in more than one group.

SOURCE: University of Delaware, The Delaware Study of Instructional Costs and Productivity, 1998-2001. 
Table D-16. Summary of determinants of direct instructional cost per student credit hour, by discipline: 2001 Delaware Study

[Dependent variable $=\log _{10}$ (Direct instructional cost per student credit hour $)$ ]

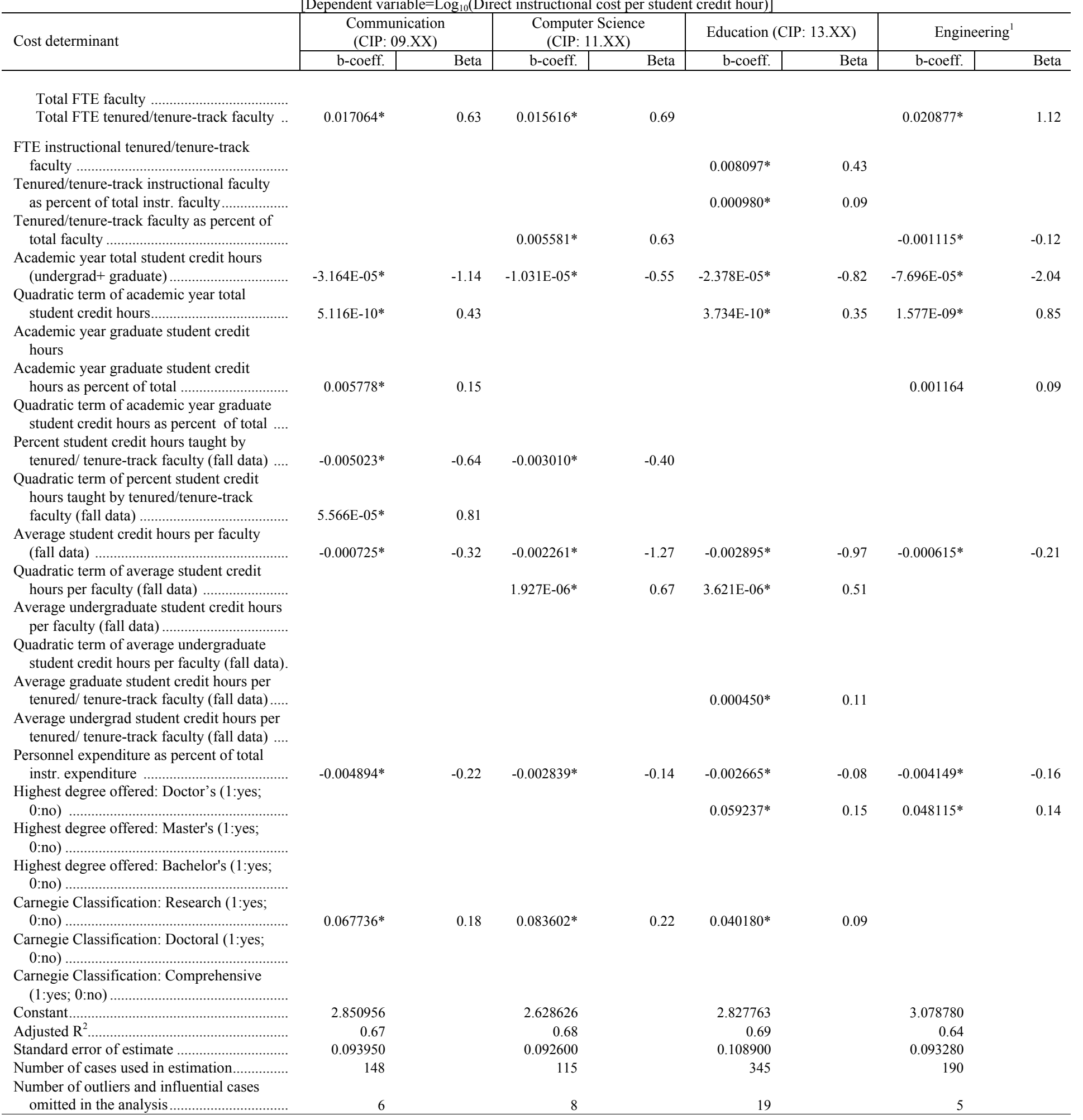

See notes at the end of the table. 
Table D-16. Summary of determinants of direct instructional cost per student credit hour, by discipline: 2001 Delaware Study-Continued

\begin{tabular}{|c|c|c|c|c|c|c|c|c|}
\hline \multirow{2}{*}{ Cost determinant } & \multicolumn{2}{|c|}{ Foreign Languages (CIP:16.XX) } & \multicolumn{2}{|c|}{ English (CIP: 23.XX) } & \multicolumn{2}{|c|}{ Biology (CIP: 26.XX) } & \multicolumn{2}{|c|}{ Mathematics (CIP: 27.XX) } \\
\hline & b-coeff. & Beta & b-coeff. & Beta & b-coeff. & Beta & b-coeff. & Beta \\
\hline Total FTE faculty ......................................... & & & & & $0.002876^{*}$ & 0.25 & & \\
\hline Total FTE tenured/tenure-track faculty .. & $0.014835^{*}$ & 0.76 & $0.007957^{*}$ & 0.72 & & & $0.013421^{*}$ & 0.89 \\
\hline \multicolumn{9}{|l|}{$\begin{array}{l}\text { FTE instructional tenured/tenure-track } \\
\text { faculty } \ldots \ldots \ldots \ldots \ldots \ldots \ldots \ldots \ldots\end{array}$} \\
\hline \multicolumn{9}{|l|}{$\begin{array}{l}\text { Tenured/tenure-track instructional faculty } \\
\text { as percent of total instr. faculty...................... }\end{array}$} \\
\hline \multicolumn{9}{|l|}{ Tenured/tenure-track faculty as percent of } \\
\hline $\begin{array}{l}\text { Academic year total student credit hours } \\
\quad \text { (undergrad }+ \text { graduate) }\end{array}$ & $-2.944 \mathrm{E}-05^{*}$ & -1.48 & $-1.334 \mathrm{E}-05^{*}$ & -1.26 & $-7.501 \mathrm{E}-06 *$ & -0.28 & $-1.813 \mathrm{E}-05^{*}$ & -1.27 \\
\hline 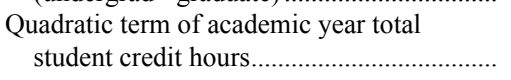 & 3.659E-10* & 0.56 & $0.000000^{*}$ & 0.50 & & & $1.063 \mathrm{E}-10^{*}$ & 0.35 \\
\hline \multicolumn{9}{|l|}{$\begin{array}{l}\text { Academic year graduate student credit } \\
\text { hours }\end{array}$} \\
\hline \multicolumn{9}{|l|}{$\begin{array}{l}\text { Academic year graduate student credit } \\
\text { hours as percent of total }\end{array}$} \\
\hline \multicolumn{9}{|l|}{$\begin{array}{l}\text { Quadratic term of academic year graduate } \\
\text { student credit hours as percent of total .... }\end{array}$} \\
\hline \multicolumn{9}{|l|}{$\begin{array}{l}\text { Percent student credit hours taught by } \\
\text { tenured/ tenure-track faculty (fall data) .... }\end{array}$} \\
\hline \multicolumn{9}{|l|}{$\begin{array}{l}\text { Quadratic term of percent student credit } \\
\text { hours taught by tenured/tenure-track } \\
\text { faculty (fall data) }\end{array}$} \\
\hline $\begin{array}{l}\text { Average student credit hours per faculty } \\
\text { (fall data) }\end{array}$ & $-0.002682 *$ & -1.15 & $-0.002813 *$ & -1.06 & $-0.001056^{*}$ & -0.48 & $-0.000769^{*}$ & -0.34 \\
\hline \multicolumn{9}{|l|}{ Quadratic term of average student credit } \\
\hline \multicolumn{9}{|l|}{$\begin{array}{l}\text { Average undergraduate student credit } \\
\text { hours per faculty (fall data) ........................ }\end{array}$} \\
\hline \multicolumn{9}{|l|}{$\begin{array}{l}\text { Quadratic term of average undergraduate } \\
\text { student credit hours per faculty (fall } \\
\text { data) }\end{array}$} \\
\hline \multicolumn{9}{|l|}{$\begin{array}{l}\text { Average graduate student credit hours per } \\
\text { tenured/ tenure-track faculty (fall data)..... }\end{array}$} \\
\hline \multicolumn{9}{|l|}{$\begin{array}{l}\text { Average undergrad student credit hours per } \\
\text { tenured/ tenure-track faculty (fall data) .... }\end{array}$} \\
\hline $\begin{array}{l}\text { Personnel expenditure as percent of total } \\
\text { instr. expenditure }\end{array}$ & & & $-0.004793 *$ & -0.10 & $-0.003555^{*}$ & -0.13 & $-0.007559^{*}$ & -0.16 \\
\hline \multicolumn{9}{|l|}{ Highest degree offered: Doctor's (1:yes; } \\
\hline 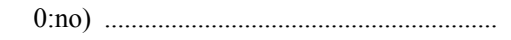 & $0.065342 *$ & 0.17 & $0.052144 *$ & 0.16 & $0.103243 *$ & 0.25 & & \\
\hline \multicolumn{9}{|l|}{$\begin{array}{l}\text { Highest degree offered: Master's (1:yes; } \\
0: \text { no) }\end{array}$} \\
\hline \multicolumn{9}{|l|}{$\begin{array}{l}\text { Highest degree offered: Bachelor's (1:yes; } \\
0: \text { no) }\end{array}$} \\
\hline \multicolumn{9}{|l|}{ Carnegie Classification: Research (1:yes; } \\
\hline 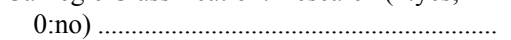 & & & & & & & $0.120510^{*}$ & 0.31 \\
\hline \multicolumn{9}{|l|}{ Carnegie Classification: Doctoral (1:yes; } \\
\hline $0:$ no) & & & & & & & $0.080747^{*}$ & 0.18 \\
\hline $\begin{array}{l}\text { Carnegie Classification: Comprehensive } \\
\quad(1: \text { yes; } 0: \text { no })\end{array}$ & & & & & -0.055899 & -0.13 & & \\
\hline 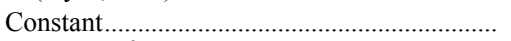 & 2.553016 & & 2.946443 & & 2.641794 & & 2.914871 & \\
\hline Adjusted $R^{2}$ & 0.66 & & 0.66 & & 0.65 & & 0.76 & \\
\hline Standard error of estimate & 0.088600 & & 0.081580 & & 0.120020 & & 0.087940 & \\
\hline Number of cases used in estimation.................... & 193 & & 174 & & 193 & & 164 & \\
\hline Number of outliers and influential cases & & & & & & & & \\
\hline 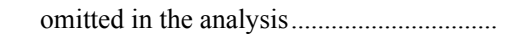 & 9 & & 7 & & 9 & & 6 & \\
\hline
\end{tabular}

See notes at the end of the table. 
Table D-16. Summary of determinants of direct instructional cost per student credit hour, by discipline: 2001 Delaware Study—Continued

[Dependent variable $=\log _{10}($ Direct instructional cost per student credit hour $\left.)\right]$

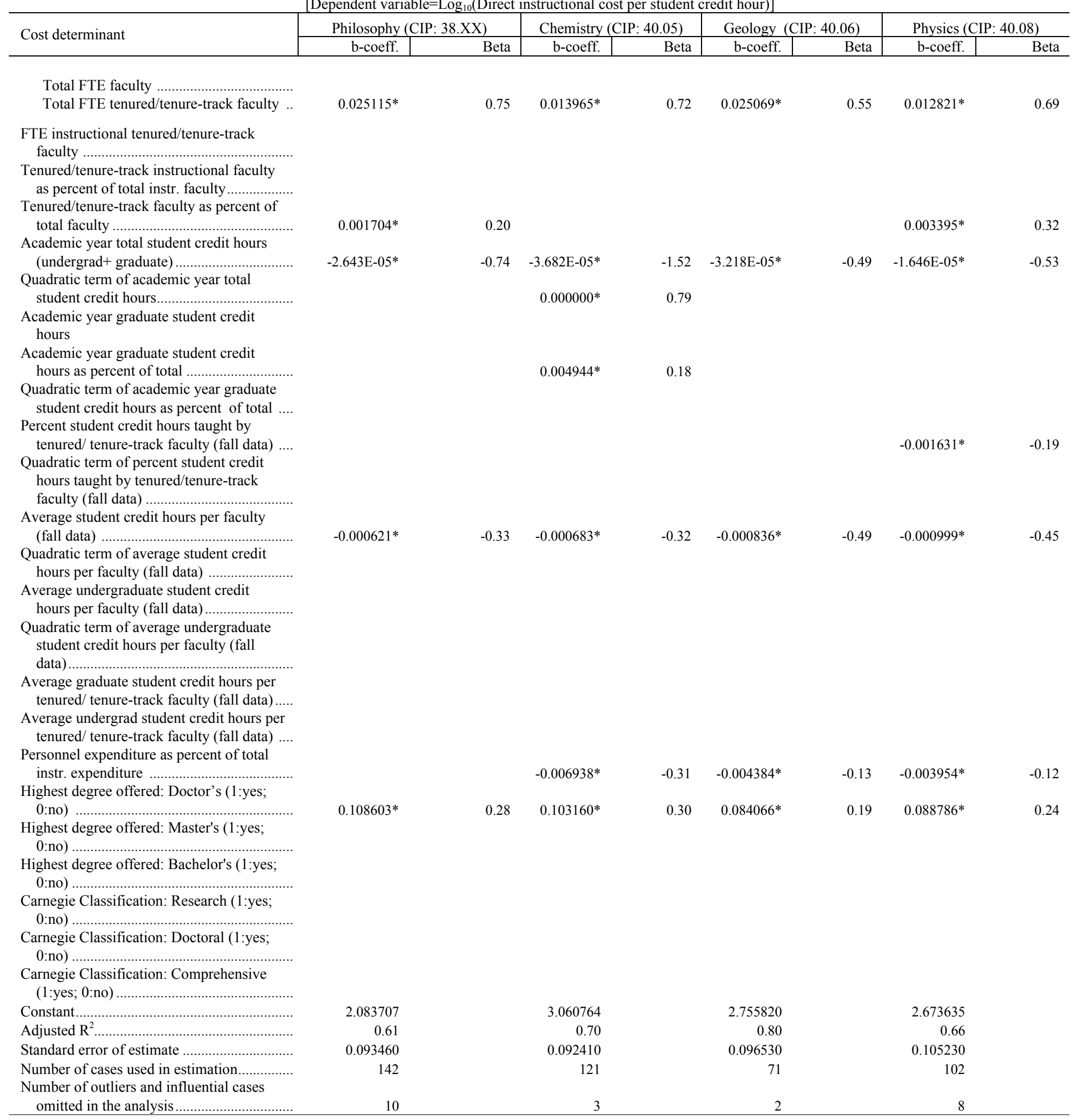

See notes at the end of the table. 
Table D-16. Summary of determinants of direct instructional cost per student credit hour, by discipline: 2001 Delaware Study—Continued

[Dependent variable $=\log _{10}($ Direct instructional cost per student credit hour $\left.)\right]$

\begin{tabular}{|c|c|c|c|c|c|c|c|c|}
\hline \multirow{2}{*}{ Cost determinant } & \multicolumn{2}{|c|}{ Psychology (CIP: 42.XX) } & \multicolumn{2}{|c|}{ Economics (CIP: 45.06) } & \multicolumn{2}{|c|}{ History (CIP: 45.08) } & \multicolumn{2}{|c|}{ Sociology (CIP: 45.11) } \\
\hline & b-coeff. & Beta & b-coeff. & Beta & b-coeff. & Beta & b-coeff. & Beta \\
\hline \multicolumn{9}{|l|}{ Total FTE faculty ....................................... } \\
\hline \multicolumn{9}{|l|}{$\begin{array}{l}\text { FTE instructional tenured/tenure-track } \\
\text { faculty }\end{array}$} \\
\hline \multicolumn{9}{|l|}{ 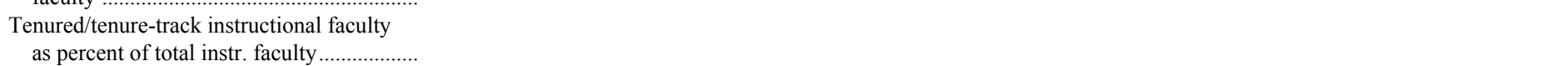 } \\
\hline \multicolumn{9}{|l|}{ Tenured/tenure-track faculty as percent of } \\
\hline \multicolumn{9}{|l|}{ Academic year total student credit hours } \\
\hline 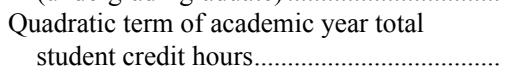 & $2.419 \mathrm{E}-10^{*}$ & 0.37 & $0.000000^{*}$ & 0.49 & $3.519 \mathrm{E}-10^{*}$ & 0.41 & & \\
\hline \multicolumn{9}{|l|}{$\begin{array}{l}\text { Academic year graduate student credit } \\
\text { hours }\end{array}$} \\
\hline \multicolumn{9}{|l|}{$\begin{array}{l}\text { Academic year graduate student credit } \\
\text { hours as percent of total ..................... }\end{array}$} \\
\hline \multicolumn{9}{|l|}{$\begin{array}{l}\text { Quadratic term of academic year graduate } \\
\text { student credit hours as percent of total .... }\end{array}$} \\
\hline \multicolumn{9}{|l|}{$\begin{array}{l}\text { Percent student credit hours taught by } \\
\text { tenured/ tenure-track faculty (fall data) .... }\end{array}$} \\
\hline \multicolumn{9}{|l|}{$\begin{array}{l}\text { Quadratic term of percent student credit } \\
\text { hours taught by tenured/tenure-track } \\
\text { faculty (fall data) }\end{array}$} \\
\hline \multicolumn{9}{|l|}{ Average student credit hours per faculty } \\
\hline \multicolumn{9}{|l|}{$\begin{array}{l}\text { Quadratic term of average student credit } \\
\text { hours per faculty (fall data) ............................... }\end{array}$} \\
\hline \multicolumn{9}{|l|}{$\begin{array}{l}\text { Average undergraduate student credit } \\
\text { hours per faculty (fall data).................... }\end{array}$} \\
\hline \multicolumn{9}{|l|}{$\begin{array}{l}\text { Quadratic term of average undergraduate } \\
\text { student credit hours per faculty (fall } \\
\text { data) }\end{array}$} \\
\hline \multicolumn{9}{|l|}{ Average graduate student credit hours per } \\
\hline \multicolumn{9}{|l|}{$\begin{array}{l}\text { Average undergrad student credit hours per } \\
\text { tenured/ tenure-track faculty (fall data) .... }\end{array}$} \\
\hline \multicolumn{7}{|l|}{ Personnel expenditure as percent of total } & $-0.005066^{*}$ & -0.12 \\
\hline \multicolumn{9}{|l|}{ Highest degree offered: Doctor's (1:yes; } \\
\hline \multicolumn{9}{|l|}{ Highest degree offered: Master's (1:yes; } \\
\hline $0:$ no) & & & $0.062445^{*}$ & 0.22 & $0.066900^{*}$ & 0.20 & & \\
\hline \multicolumn{9}{|l|}{ Highest degree offered: Bachelor's (1:yes; } \\
\hline \multicolumn{9}{|l|}{ Carnegie Classification: Research (1:yes; } \\
\hline $\begin{array}{l}\text { Carnegie Classification: Doctoral (1:yes; } \\
0: \text { no) }\end{array}$ & & & & & & & & \\
\hline \multicolumn{9}{|l|}{ 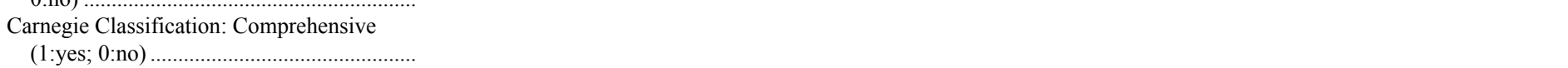 } \\
\hline 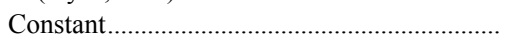 & 2.955874 & & 2.228765 & & 2.179921 & & 2.673010 & \\
\hline 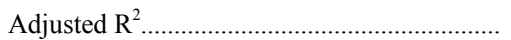 & 0.63 & & 0.70 & & 0.70 & & 0.66 & \\
\hline 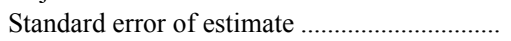 & 0.105130 & & 0.072800 & & 0.090730 & & 0.087650 & \\
\hline Number of cases used in estimation................. & 148 & & 77 & & 126 & & 104 & \\
\hline $\begin{array}{l}\text { Number of outliers and influential cases } \\
\text { omitted in the analysis................................... }\end{array}$ & 4 & & 1 & & 3 & & 3 & \\
\hline
\end{tabular}

See notes at end of table. 
Table D-16. Summary of determinants of direct instructional cost per student credit hour, by discipline: 2001 Delaware Study - Continued

[Dependent variable $=\log _{10}$ (Direct instructional cost per student credit hour)]

\begin{tabular}{|c|c|c|c|c|c|c|c|c|}
\hline \multirow{2}{*}{ Cost determinant } & \multicolumn{2}{|c|}{ Other social sciences ${ }^{2}$} & \multicolumn{2}{|c|}{ Art (CIP: 50.XX) } & \multicolumn{2}{|c|}{ Nursing (CIP: 51.16) } & \multicolumn{2}{|c|}{ Business $^{3}$} \\
\hline & b-coeff. & Beta & b-coeff. & Beta & b-coeff. & Beta & b-coeff. & Beta \\
\hline $\begin{array}{l}\text { Total FTE faculty .................................... } \\
\text { Total FTE tenured/tenure-track faculty .. }\end{array}$ & \multicolumn{8}{|c|}{ Total FTE faculty } \\
\hline \multicolumn{9}{|l|}{$\begin{array}{l}\text { FTE instructional tenured/tenure-track } \\
\text { faculty }\end{array}$} \\
\hline \multicolumn{9}{|l|}{ 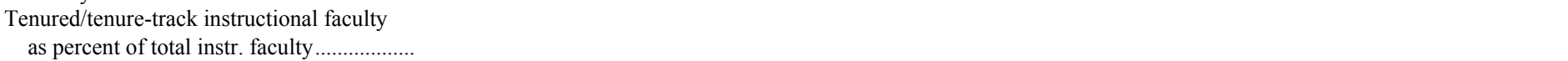 } \\
\hline $\begin{array}{l}\text { Tenured/tenure-track faculty as percent of } \\
\text { total faculty }\end{array}$ & & & 0.000621 & 0.07 & 0.001347 & 0.21 & $0.002416^{*}$ & 0.28 \\
\hline $\begin{array}{l}\text { Academic year total student credit hours } \\
\quad(\text { undergrad }+ \text { graduate })\end{array}$ & $-2.729 \mathrm{E}-05^{*}$ & -0.72 & $-1.558 \mathrm{E}-05^{*}$ & -0.53 & & & $-1.590 \mathrm{E}-05^{*}$ & -0.86 \\
\hline 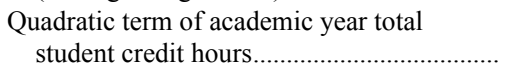 & & & & & & & $8.526 \mathrm{E}-11 *$ & 0.17 \\
\hline \multicolumn{9}{|l|}{$\begin{array}{l}\text { Academic year graduate student credit } \\
\text { hours }\end{array}$} \\
\hline 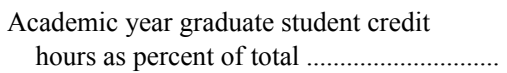 & $0.004912 *$ & 0.15 & & & $0.006699 *$ & 0.68 & & \\
\hline $\begin{array}{l}\text { Quadratic term of academic year graduate } \\
\text { student credit hours as percent of total .... }\end{array}$ & & & & & $-0.000104 *$ & -0.74 & & \\
\hline $\begin{array}{l}\text { Percent student credit hours taught by } \\
\text { tenured/ tenure-track faculty (fall data) .... }\end{array}$ & & & & & & & $-0.001223^{*}$ & -0.17 \\
\hline 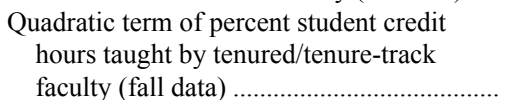 & & & & & & & & \\
\hline $\begin{array}{l}\text { Average student credit hours per faculty } \\
\text { (fall data) }\end{array}$ & $-0.000847 *$ & -0.46 & $-0.003032 *$ & -1.12 & $-0.005351 *$ & -1.49 & $-0.001035^{*}$ & -0.57 \\
\hline 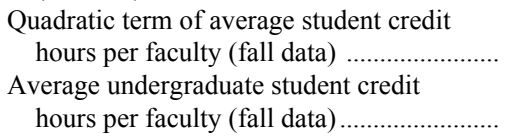 & & & 4.433E-06* & 0.66 & $1.066 \mathrm{E}-05^{*}$ & 0.84 & & \\
\hline 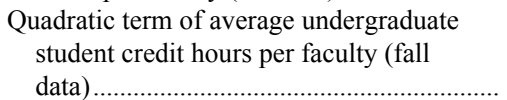 & & & & & & & & \\
\hline $\begin{array}{l}\text { Average graduate student credit hours per } \\
\text { tenured/ tenure-track faculty (fall data)..... }\end{array}$ & & & $0.001857^{*}$ & 0.13 & & & $0.000337^{*}$ & 0.09 \\
\hline $\begin{array}{l}\text { Average undergrad student credit hours per } \\
\text { tenured/ tenure-track faculty (fall data) .... }\end{array}$ & & & & & & & & \\
\hline $\begin{array}{l}\text { Personnel expenditure as percent of total } \\
\text { instr. expenditure }\end{array}$ & $-0.005590 *$ & -0.17 & $-0.005562 *$ & -0.23 & $-0.008636^{*}$ & -0.38 & $-0.006722 *$ & -0.17 \\
\hline $\begin{array}{l}\text { Highest degree offered: Doctor's }(1: y e s ; \\
\quad 0: n o) \\
\text { Highest degree offered: Master's }(1: y e s ; \\
\quad 0: \text { no) }\end{array}$ & & & & & & & & \\
\hline 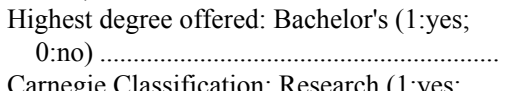 & $0.034275^{*}$ & 0.10 & & & & & $0.018645^{*}$ & 0.06 \\
\hline $\begin{array}{l}\text { Carnegie Classification: Research (1:yes; } \\
0: \text { no) }\end{array}$ & & & $0.030539 *$ & 0.08 & $0.112895^{*}$ & 0.32 & $0.207096^{*}$ & 0.61 \\
\hline $\begin{array}{l}\text { Carnegie Classification: Doctoral (1:yes; } \\
0: \text { no) }\end{array}$ & & & & & & & $0.177990^{*}$ & 0.51 \\
\hline $\begin{array}{l}\text { Carnegie Classification: Comprehensive } \\
\quad(1: y e s ; 0: \text { no })\end{array}$ & $-0.038218^{*}$ & -0.11 & & & & & $0.124025^{*}$ & 0.43 \\
\hline 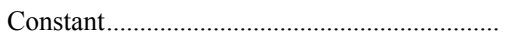 & 2.862103 & & 3.099232 & & 3.668123 & & 2.883694 & \\
\hline 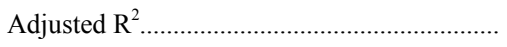 & 0.66 & & 0.60 & & 0.69 & & 0.60 & \\
\hline 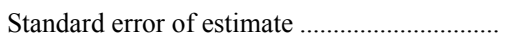 & 0.097100 & & 0.102760 & & 0.077750 & & 0.091250 & \\
\hline $\begin{array}{l}\text { Number of cases used in estimation............... } \\
\text { Number of outliers and influential cases }\end{array}$ & 222 & & 337 & & 81 & & 392 & \\
\hline omitted in the analysis ................................... & 10 & & 12 & & 5 & & 23 & \\
\hline
\end{tabular}

$* \mathrm{p}=0.05$

${ }^{1}$ Includes Chemical Engineering (14.07), Civil Engineering ( 14.08), Electrical Engineering (14.10), and Mechanical Engineering (14.19).

${ }^{2}$ Includes Political Science (45.10), Anthropology (45.02), and Geography (45.07).

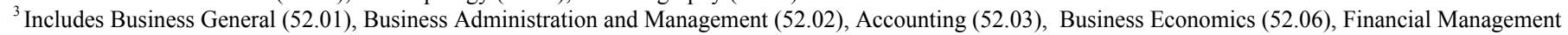
(52.08), International Business (52.11), Business Information (52.12), Business Quantitative Methods (52.13) \& Marketing (52.14).

NOTE: Cost determinant is included in equation if coefficient is significant at the 10 percent level.

SOURCE: University of Delaware, The Delaware Study of Instructional Costs and Productivity, 1998-2001. 
Table D-17. Summary of determinants of direct instructional cost per student credit hour, by discipline: 2000 Delaware Study

[Dependent variable $=\log _{10}($ Direct instructional cost per student credit hour $\left.)\right]$

\begin{tabular}{|c|c|c|c|c|c|c|c|c|}
\hline \multirow[t]{2}{*}{ Cost determinant } & \multicolumn{2}{|c|}{$\begin{array}{l}\text { Communication } \\
\text { (CIP: 09.XX) }\end{array}$} & \multicolumn{2}{|c|}{$\begin{array}{l}\text { Computer Science } \\
\text { (CIP: } 11 . \mathrm{XX})\end{array}$} & \multicolumn{2}{|c|}{ Education (CIP: 13.XX) } & \multicolumn{2}{|c|}{ Engineering ${ }^{1}$} \\
\hline & b-coeff. & Beta & b-coeff. & Beta & b-coeff. & Beta & b-coeff. & Beta \\
\hline Total FTE faculty & $0.013160^{*}$ & 0.84 & & & $0.006121^{*}$ & 0.61 & & \\
\hline Total FTE tenured/tenure-track faculty .. & & & & & & & $0.009967^{*}$ & 0.82 \\
\hline $\begin{array}{l}\text { FTE instructional tenured/tenure-track } \\
\text { faculty }\end{array}$ & & & $0.009921 *$ & 0.39 & & & & \\
\hline $\begin{array}{l}\text { Tenured/tenure-track instructional faculty } \\
\text { as percent of total instr. faculty....................... }\end{array}$ & $0.002869 *$ & 0.31 & $0.002036^{*}$ & 0.24 & $0.002998^{*}$ & 0.26 & & \\
\hline $\begin{array}{l}\text { Tenured/tenure-track faculty as percent of } \\
\text { total faculty }\end{array}$ & & & & & & & $0.002177^{*}$ & 0.25 \\
\hline $\begin{array}{l}\text { Academic year total student credit hours } \\
\text { (undergrad }+ \text { graduate) }\end{array}$ & $-4.731 \mathrm{E}-05^{*}$ & -1.51 & $-7.788 \mathrm{E}-06^{*}$ & -0.38 & $-2.385 \mathrm{E}-05^{*}$ & -0.88 & $-3.204 \mathrm{E}-05^{*}$ & -1.35 \\
\hline 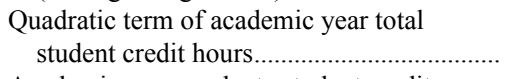 & $7.988 \mathrm{E}-10^{*}$ & 0.64 & & & $2.900 \mathrm{E}-10^{*}$ & 0.32 & $4.015 \mathrm{E}-10^{*}$ & 0.43 \\
\hline $\begin{array}{l}\text { Academic year graduate student credit } \\
\text { hours }\end{array}$ & & & & & $-8.987 \mathrm{E}-06 *$ & -0.14 & & \\
\hline $\begin{array}{l}\text { Academic year graduate student credit } \\
\text { hours as percent of total .................................. }\end{array}$ & & & & & $0.001822 *$ & 0.27 & $0.001625^{*}$ & 0.13 \\
\hline $\begin{array}{l}\text { Quadratic term of academic year graduate } \\
\text { student credit hours as percent of total .... }\end{array}$ & & & & & & & & \\
\hline $\begin{array}{l}\text { Percent student credit hours taught by } \\
\text { tenured/ tenure-track faculty (fall data) .... }\end{array}$ & $0.001286^{*}$ & 0.16 & & & & & & \\
\hline 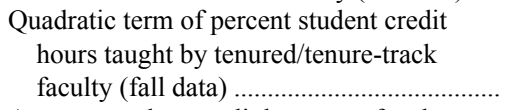 & & & & & & & & \\
\hline $\begin{array}{l}\text { Average student credit hours per faculty } \\
\text { (fall data) }\end{array}$ & $-3.303 \mathrm{E}-04 *$ & -0.15 & & & $-0.001776^{*}$ & -0.57 & $-0.002835^{*}$ & -0.96 \\
\hline $\begin{array}{l}\text { Quadratic term of average student credit } \\
\text { hours per faculty (fall data) ................................ }\end{array}$ & & & & & $1.799 \mathrm{E}-06 *$ & 0.24 & $4.156 \mathrm{E}-06^{*}$ & 0.48 \\
\hline 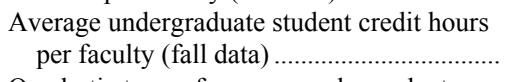 & & & $-0.002169^{*}$ & -1.15 & & & & \\
\hline $\begin{array}{l}\text { Quadratic term of average undergraduate } \\
\text { student credit hours per faculty (fall data). }\end{array}$ & & & $2.273 \mathrm{E}-06^{*}$ & 0.70 & & & & \\
\hline $\begin{array}{l}\text { Average graduate student credit hours per } \\
\text { tenured/ tenure-track faculty (fall data)...... }\end{array}$ & & & & & & & & \\
\hline $\begin{array}{l}\text { Average undergrad student credit hours per } \\
\text { tenured/ tenure-track faculty (fall data) .... }\end{array}$ & & & & & & & & \\
\hline $\begin{array}{l}\text { Personnel expenditure as percent of total } \\
\text { instr. expenditure }\end{array}$ & $-0.007065^{*}$ & -0.25 & $-0.004156^{*}$ & -0.21 & $-0.005644 *$ & -0.18 & $-0.004294 *$ & -0.24 \\
\hline $\begin{array}{l}\text { Highest degree offered: Doctor's (1:yes; } \\
0: n o)\end{array}$ & & & & & & & & \\
\hline $\begin{array}{l}\text { Highest degree offered: Master's (1:yes; } \\
0: \text { no) }\end{array}$ & $0.048331 *$ & 0.13 & & & & & & \\
\hline $\begin{array}{l}\text { Highest degree offered: Bachelor's (1:yes; } \\
0: \text { no) }\end{array}$ & & & & & & & & \\
\hline $\begin{array}{l}\text { Carnegie Classification: Research (1:yes; } \\
\text { 0:no) }\end{array}$ & $0.080381 *$ & 0.21 & $0.094296^{*}$ & 0.27 & $0.050930 *$ & 0.12 & $0.054706^{*}$ & 0.20 \\
\hline $\begin{array}{l}\text { Carnegie Classification: Doctoral (1:yes; } \\
0: \text { no) }\end{array}$ & & & & & & & & \\
\hline $\begin{array}{l}\text { Carnegie Classification: Comprehensive } \\
\quad(1: \text { yes; 0:no) }\end{array}$ & & & & & & & & \\
\hline 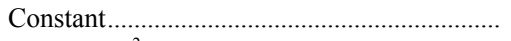 & 2.656497 & & 2.754042 & & 2.824106 & & 3.043519 & \\
\hline Adjusted $\mathrm{R}^{2} \ldots \ldots$ & 0.70 & & 0.65 & & 0.73 & & 0.69 & \\
\hline 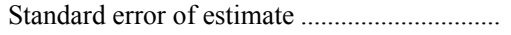 & 0.097260 & & 0.098060 & & 0.103960 & & 0.073790 & \\
\hline Number of cases used in estimation.................. & 131 & & 102 & & 313 & & 176 & \\
\hline Number of outliers and influential cases & & & & & & & & \\
\hline omitted in the analysis ..................................... & 2 & & 0 & & 6 & & 5 & \\
\hline
\end{tabular}

See notes at end of table. 
Table D-17. Summary of determinants of direct instructional cost per student credit hour, by discipline: 2000 Delaware Study-Continued

\begin{tabular}{|c|c|c|c|c|c|c|c|c|}
\hline \multirow{2}{*}{ Cost determinant } & \multicolumn{2}{|c|}{ Foreign Languages (CIP:16.XX) } & \multicolumn{2}{|c|}{ English (CIP: 23.XX) } & \multicolumn{2}{|c|}{ Biology (CIP: 26.XX) } & \multicolumn{2}{|c|}{ Mathematics (CIP: 27.XX) } \\
\hline & b-coeff. & Beta & b-coeff. & Beta & b-coeff. & Beta & b-coeff. & Beta \\
\hline \multicolumn{8}{|l|}{ Total FTE tenured/tenure-track faculty .. } & 0.89 \\
\hline \multicolumn{9}{|l|}{ 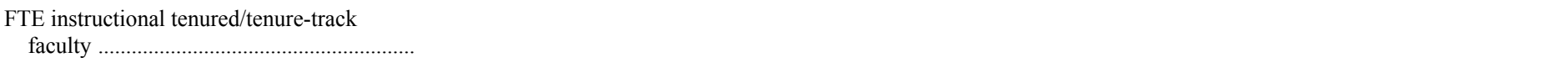 } \\
\hline \multicolumn{8}{|l|}{ Tenured/tenure-track instructional faculty } & 0.38 \\
\hline \multicolumn{9}{|l|}{$\begin{array}{l}\text { Tenured/tenure-track faculty as percent of } \\
\text { total faculty }\end{array}$} \\
\hline 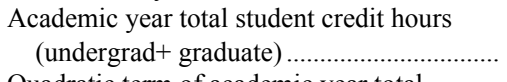 & $-1.954 \mathrm{E}-05^{*}$ & -0.99 & $-1.192 \mathrm{E}-05^{*}$ & -1.12 & $-7.813 \mathrm{E}-06^{*}$ & -0.35 & $-9.225 \mathrm{E}-06^{*}$ & -0.92 \\
\hline \multicolumn{8}{|l|}{ Quadratic term of academic year total } & \\
\hline \multicolumn{9}{|l|}{$\begin{array}{l}\text { Academic year graduate student credit } \\
\text { hours }\end{array}$} \\
\hline \multicolumn{8}{|l|}{ Academic year graduate student credit } & \\
\hline \multicolumn{9}{|l|}{ Quadratic term of academic year graduate } \\
\hline $\begin{array}{l}\text { Percent student credit hours taught by } \\
\text { tenured/ tenure-track faculty (fall data) .... }\end{array}$ & \multicolumn{8}{|c|}{ Percent student credit hours taught by } \\
\hline 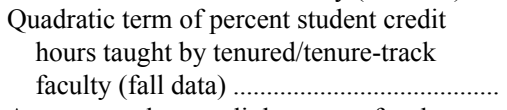 & & & & & $-0.000043^{*}$ & -0.52 & & \\
\hline \multicolumn{9}{|l|}{ Average student credit hours per faculty } \\
\hline \multicolumn{9}{|l|}{ Quadratic term of average student credit } \\
\hline \multicolumn{9}{|l|}{$\begin{array}{l}\text { Average undergraduate student credit } \\
\text { hours per faculty (fall data) ..................... }\end{array}$} \\
\hline \multicolumn{9}{|l|}{ 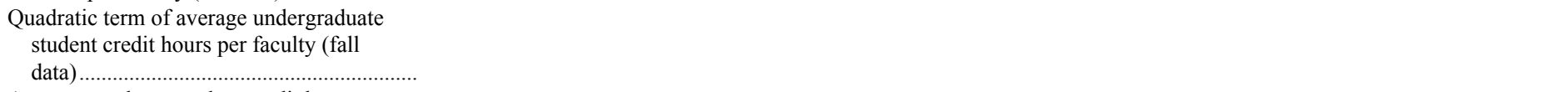 } \\
\hline \multicolumn{8}{|l|}{ Average graduate student credit hours per } & \\
\hline \multicolumn{9}{|l|}{$\begin{array}{l}\text { Average undergrad student credit hours per } \\
\text { tenured/ tenure-track faculty (fall data) .... }\end{array}$} \\
\hline $\begin{array}{l}\text { Personnel expenditure as percent of total } \\
\text { instr. expenditure }\end{array}$ & -0.002291 & -0.09 & $-0.004081 *$ & -0.12 & $-0.008318^{*}$ & -0.28 & $-0.004609 *$ & -0.12 \\
\hline $\begin{array}{l}\text { Highest degree offered: Doctor's (1:yes; } \\
\quad 0: \text { no) }\end{array}$ & & & $0.049759 *$ & 0.16 & $0.070691 *$ & 0.15 & & \\
\hline \multicolumn{9}{|l|}{$\begin{array}{l}\text { Highest degree offered: Master's (1:yes; } \\
\quad 0: \text { no) }\end{array}$} \\
\hline \multicolumn{9}{|l|}{$\begin{array}{l}\text { Highest degree offered: Bachelor's (1:yes; } \\
\qquad: \text { no) }\end{array}$} \\
\hline \multicolumn{9}{|l|}{ Carnegie Classification: Research (1:yes; } \\
\hline \multicolumn{9}{|l|}{ Carnegie Classification: Doctoral (1:yes; } \\
\hline \multicolumn{9}{|l|}{$\begin{array}{l}\text { Carnegie Classification: Comprehensive } \\
\quad(1: y e s ; 0: \text { no })\end{array}$} \\
\hline 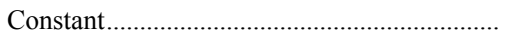 & 2.616554 & & 2.542872 & & 2.899395 & & 2.675949 & \\
\hline 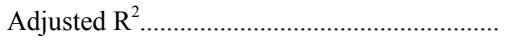 & 0.69 & & 0.63 & & 0.73 & & 0.73 & \\
\hline Standard error of estimate ................................ & 0.086520 & & 0.086420 & & 0.119310 & & 0.084600 & \\
\hline Number of cases used in estimation................ & 159 & & 158 & & 182 & & 139 & \\
\hline Number of outliers and influential cases & & & & & & & & \\
\hline 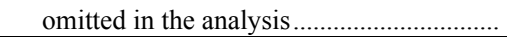 & 7 & & 2 & & 4 & & 2 & \\
\hline
\end{tabular}

See notes at end of table. 
Table D-17. Summary of determinants of direct instructional cost per student credit hour, by discipline: 2000 Delaware Study-Continued

[Dependent variable $=\log _{10}$ (Direct instructional cost per student credit hour)]

\begin{tabular}{|c|c|c|c|c|c|c|c|c|}
\hline \multirow{2}{*}{ Cost determinant } & \multicolumn{2}{|c|}{ Philosophy (CIP: 38.XX) } & \multicolumn{2}{|c|}{ Chemistry (CIP: 40.05) } & \multicolumn{2}{|c|}{ Geology (CIP: 40.06) } & \multicolumn{2}{|c|}{ Physics (CIP: 40.08) } \\
\hline & b-coeff. & Beta & b-coeff. & Beta & b-coeff. & Beta & b-coeff. & Beta \\
\hline 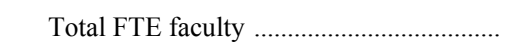 & & & $0.002203 *$ & 0.35 & $0.011214 *$ & 0.53 & & \\
\hline Total FTE tenured/tenure-track faculty .. & $0.015942 *$ & 0.50 & & & & & $0.008633 *$ & 0.61 \\
\hline \multicolumn{9}{|l|}{$\begin{array}{l}\text { FTE instructional tenured/tenure-track } \\
\text { faculty }\end{array}$} \\
\hline $\begin{array}{l}\text { Tenured/tenure-track instructional faculty } \\
\text { as percent of total instr. faculty..................... }\end{array}$ & & & $0.003330^{*}$ & 0.37 & $0.004537 *$ & 0.33 & $0.002231 *$ & 0.19 \\
\hline $\begin{array}{l}\text { Tenured/tenure-track faculty as percent of } \\
\text { total faculty }\end{array}$ & $0.002334 *$ & 0.26 & & & & & & \\
\hline $\begin{array}{l}\text { Academic year total student credit hours } \\
\quad \text { (undergrad }+ \text { graduate })\end{array}$ & $-1.496 \mathrm{E}-05 *$ & -0.41 & $-6.118 \mathrm{E}-06^{*}$ & -0.34 & $-3.258 \mathrm{E}-05^{*}$ & -0.59 & $-1.058 \mathrm{E}-05^{*}$ & -0.44 \\
\hline 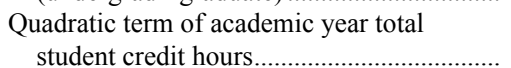 & & & & & & & & \\
\hline $\begin{array}{l}\text { Academic year graduate student credit } \\
\text { hours }\end{array}$ & & & & & & & & \\
\hline $\begin{array}{l}\text { Academic year graduate student credit } \\
\text { hours as percent of total ................................ }\end{array}$ & & & & & & & & \\
\hline $\begin{array}{l}\text { Quadratic term of academic year graduate } \\
\text { student credit hours as percent of total .... }\end{array}$ & & & & & & & & \\
\hline $\begin{array}{l}\text { Percent student credit hours taught by } \\
\text { tenured/ tenure-track faculty (fall data) .... }\end{array}$ & & & & & & & & \\
\hline $\begin{array}{l}\text { Quadratic term of percent student credit } \\
\text { hours taught by tenured/tenure-track } \\
\text { faculty (fall data) }\end{array}$ & & & & & & & & \\
\hline $\begin{array}{l}\text { Average student credit hours per faculty } \\
\text { (fall data) }\end{array}$ & $-1.042 \mathrm{E}-03 *$ & -0.48 & $-0.001146^{*}$ & -0.52 & & & & \\
\hline $\begin{array}{l}\text { Quadratic term of average student credit } \\
\text { hours per faculty (fall data) }\end{array}$ & & & & & & & & \\
\hline Average undergraduate student credit & & & & & & & & \\
\hline 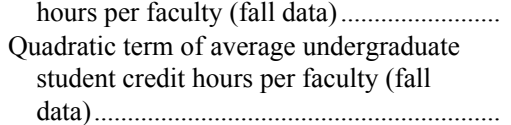 & & & & & $-0.001237^{*}$ & -0.57 & $-0.001011^{*}$ & -0.50 \\
\hline $\begin{array}{l}\text { Average graduate student credit hours per } \\
\text { tenured/ tenure-track faculty (fall data)...... }\end{array}$ & & & $0.002326^{*}$ & 0.34 & & & & \\
\hline $\begin{array}{l}\text { Average undergrad student credit hours per } \\
\text { tenured/ tenure-track faculty (fall data) .... }\end{array}$ & & & $-0.000291 *$ & -0.15 & & & & \\
\hline $\begin{array}{l}\text { Personnel expenditure as percent of total } \\
\text { instr. expenditure }\end{array}$ & & & $-0.005637 *$ & -0.26 & $-0.005903^{*}$ & -0.17 & $-0.004407 *$ & -0.18 \\
\hline Highest degree offered: Doctor's (1:yes; & & & & & & & & \\
\hline $0:$ no) & $0.086975^{*}$ & 0.23 & $0.150167 *$ & 0.44 & $0.148984 *$ & 0.35 & $0.096032 *$ & 0.27 \\
\hline $\begin{array}{l}\text { Highest degree offered: Master's (1:yes; } \\
0: \text { no) }\end{array}$ & & & & & $0.070181 *$ & 0.15 & & \\
\hline $\begin{array}{l}\text { Highest degree offered: Bachelor's (1:yes; } \\
0: \text { no) }\end{array}$ & & & & & & & & \\
\hline $\begin{array}{l}\text { Carnegie Classification: Research (1:yes; } \\
0: \text { no) }\end{array}$ & & & & & & & & \\
\hline $\begin{array}{l}\text { Carnegie Classification: Doctoral (1:yes; } \\
0: \text { no) }\end{array}$ & & & & & & & & \\
\hline $\begin{array}{l}\text { Carnegie Classification: Comprehensive } \\
\quad(1: \text { yes; 0:no) }\end{array}$ & & & 0.041038 & 0.12 & & & & \\
\hline 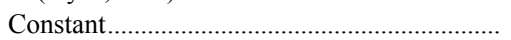 & 2.151888 & & 2.775292 & & 2.677000 & & 2.675848 & \\
\hline 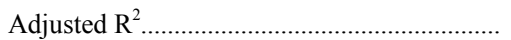 & 0.60 & & 0.79 & & 0.82 & & 0.72 & \\
\hline 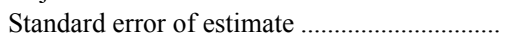 & 0.098600 & & 0.077970 & & 0.090290 & & 0.095080 & \\
\hline Number of cases used in estimation................. & 118 & & 108 & & 71 & & 95 & \\
\hline $\begin{array}{l}\text { Number of outliers and influential cases } \\
\text { omitted in the analysis..................................... }\end{array}$ & 5 & & 0 & & 1 & & 1 & \\
\hline
\end{tabular}

See notes at end of table. 
Table D-17. Summary of determinants of direct instructional cost per student credit hour, by discipline: 2000 Delaware Study—Continued

[Dependent variable $=\log _{10}($ Direct instructional cost per student credit hour $\left.)\right]$

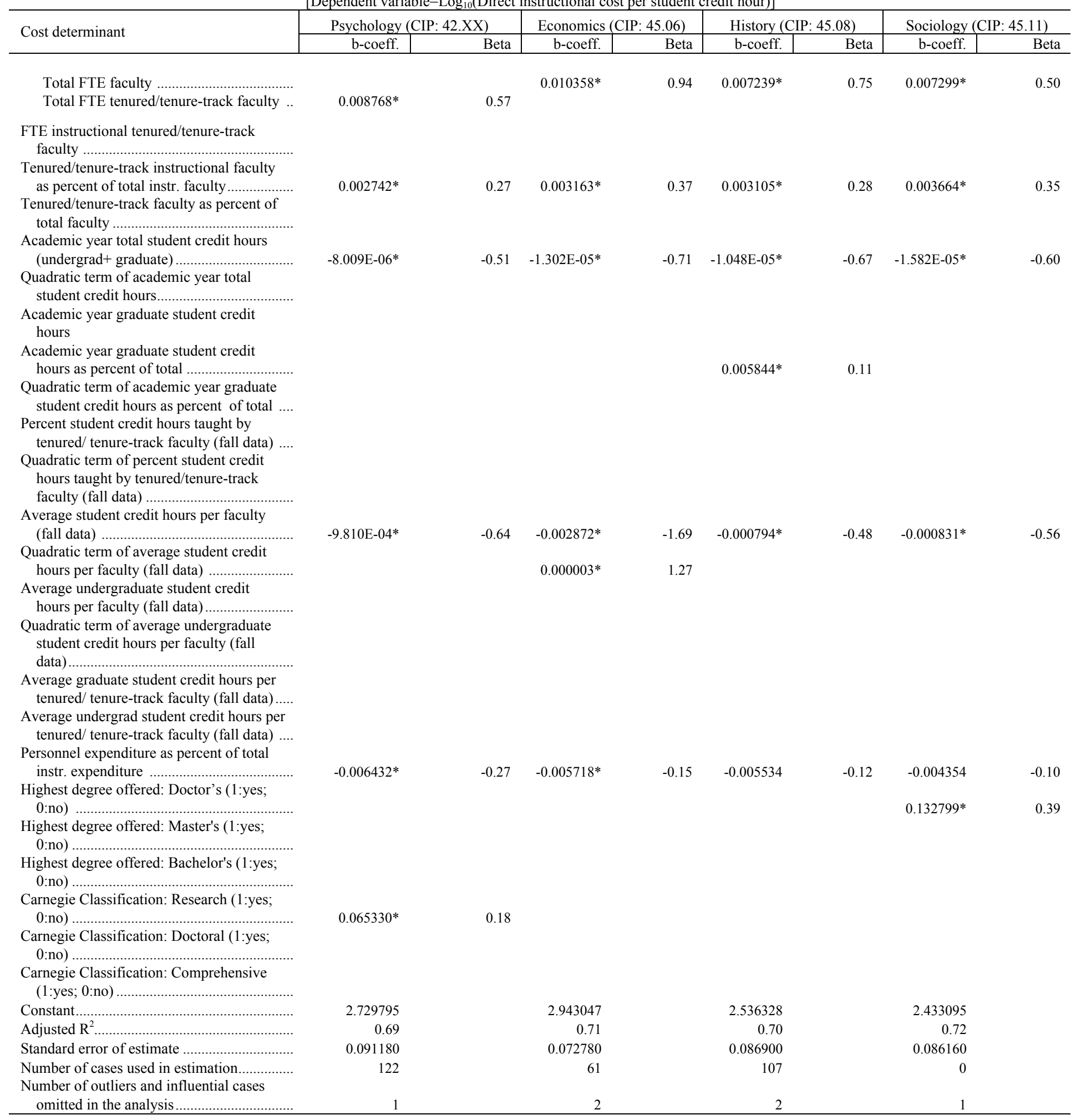

See notes at end of table. 
Table D-17. Summary of determinants of direct instructional cost per student credit hour, by discipline: 2000 Delaware Study—Continued

[Dependent variable $=\log _{10}$ (Direct instructional cost per student credit hour)]

\begin{tabular}{|c|c|c|c|c|c|c|c|c|}
\hline \multirow{2}{*}{ Cost determinant } & \multicolumn{2}{|c|}{ Other social sciences ${ }^{2}$} & \multicolumn{2}{|c|}{ Art (CIP: 50.XX) } & \multicolumn{2}{|c|}{ Nursing (CIP: 51.16) } & \multicolumn{2}{|c|}{ Business $^{3}$} \\
\hline & b-coeff. & Beta & b-coeff. & Beta & b-coeff. & Beta & b-coeff. & Beta \\
\hline 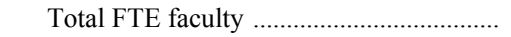 & & & $0.006300 *$ & 0.67 & $0.007983 *$ & 0.80 & $0.005955^{*}$ & 0.75 \\
\hline Total FTE tenured/tenure-track faculty .. & $0.021835^{*}$ & 0.88 & & & & & & \\
\hline \multicolumn{9}{|l|}{$\begin{array}{l}\text { FTE instructional tenured/tenure-track } \\
\text { faculty }\end{array}$} \\
\hline \multicolumn{9}{|l|}{ Tenured/tenure-track instructional faculty } \\
\hline as percent of total instr. faculty ................... & & & $0.001393 *$ & 0.16 & & & $0.002784 *$ & 0.32 \\
\hline $\begin{array}{l}\text { Tenured/tenure-track faculty as percent of } \\
\text { total faculty }\end{array}$ & & & & & 0.001036 & 0.14 & & \\
\hline $\begin{array}{l}\text { Academic year total student credit hours } \\
\quad(\text { undergrad }+ \text { graduate })\end{array}$ & $-5.436 \mathrm{E}-05^{*}$ & -1.77 & $-2.079 \mathrm{E}-05^{*}$ & -0.74 & $-7.642 \mathrm{E}-05^{*}$ & -1.92 & $-8.603 \mathrm{E}-06^{*}$ & -0.72 \\
\hline 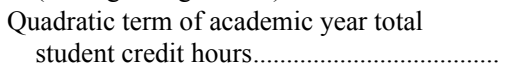 & $9.974 \mathrm{E}-10 *$ & 0.79 & & & $2.587 \mathrm{E}-09 *$ & 1.04 & & \\
\hline \multicolumn{9}{|l|}{$\begin{array}{l}\text { Academic year graduate student credit } \\
\text { hours }\end{array}$} \\
\hline \multicolumn{9}{|l|}{ Academic year graduate student credit } \\
\hline $\begin{array}{l}\text { Quadratic term of academic year graduate } \\
\text { student credit hours as percent of total .... }\end{array}$ & & & & & & & -0.000088 & -0.19 \\
\hline \multicolumn{9}{|l|}{$\begin{array}{l}\text { Percent student credit hours taught by } \\
\text { tenured/ tenure-track faculty (fall data) .... }\end{array}$} \\
\hline \multicolumn{9}{|l|}{ 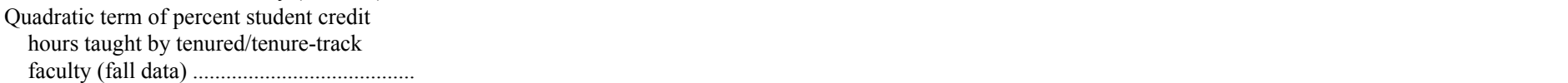 } \\
\hline \multicolumn{9}{|l|}{ Average student credit hours per faculty } \\
\hline \multicolumn{8}{|l|}{$\begin{array}{l}\text { Average undergraduate student credit } \\
\text { hours per faculty (fall data) ........................ }\end{array}$} & 0.61 \\
\hline \multicolumn{9}{|l|}{$\begin{array}{l}\text { Quadratic term of average undergraduate } \\
\text { student credit hours per faculty (fall } \\
\text { data) }\end{array}$} \\
\hline \multicolumn{9}{|l|}{ Average graduate student credit hours per } \\
\hline \multicolumn{9}{|l|}{$\begin{array}{l}\text { Average undergrad student credit hours per } \\
\text { tenured/ tenure-track faculty (fall data) .... }\end{array}$} \\
\hline $\begin{array}{l}\text { Personnel expenditure as percent of total } \\
\text { instr. expenditure }\end{array}$ & $-0.006040 *$ & -0.20 & $-0.006096^{*}$ & -0.24 & $-0.008306^{*}$ & -0.35 & $-0.009544 *$ & -0.25 \\
\hline $\begin{array}{l}\text { Highest degree offered: Doctor's (1:yes; } \\
\quad 0: \text { no) }\end{array}$ & $0.084254^{*}$ & 0.24 & $0.040798 *$ & 0.09 & & & & \\
\hline $\begin{array}{l}\text { Highest degree offered: Master's (1:yes; } \\
\quad 0: \text { no) }\end{array}$ & $0.033355^{*}$ & 0.10 & & & & & & \\
\hline $\begin{array}{l}\text { Highest degree offered: Bachelor's (1:yes; } \\
\quad 0: \text { no) }\end{array}$ & & & & & & & & \\
\hline Carnegie Classification: Research (1:yes; & & & & & & & & \\
\hline 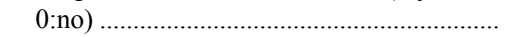 & & & & & $0.089910^{*}$ & 0.25 & $0.171006^{*}$ & 0.57 \\
\hline $\begin{array}{r}\text { Carnegie Classification: Doctoral (1:yes; } \\
0: \text { no) }\end{array}$ & & & & & & & 0.142389 & 0.38 \\
\hline $\begin{array}{l}\text { Carnegie Classification: Comprehensive } \\
\quad(1: \text { yes; } 0: \text { no })\end{array}$ & & & & & & & 0.118585 & 0.43 \\
\hline 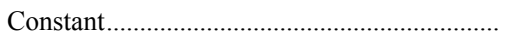 & 2.911062 & & 2.886270 & & 3.648880 & & 3.126610 & \\
\hline 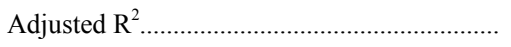 & 0.73 & & 0.57 & & 0.68 & & 0.53 & \\
\hline Standard error of estimate .............................. & 0.083540 & & 0.103900 & & 0.090560 & & 0.095000 & \\
\hline $\begin{array}{l}\text { Number of cases used in estimation............... } \\
\text { Number of outliers and influential cases }\end{array}$ & 191 & & 318 & & 76 & & 334 & \\
\hline 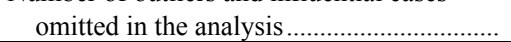 & 8 & & 4 & & 1 & & 14 & \\
\hline
\end{tabular}

$\mathrm{p}=0.05$.

${ }_{1}^{1}$ Includes Chemical Engineering (14.07), Civil Engineering ( 14.08), Electrical Engineering (14.10), and Mechanical Engineering (14.19).

${ }^{2}$ Includes Political Science (45.10), Anthropology (45.02), and Geography (45.07).

${ }^{3}$ Includes Business General (52.01), Business Administration and Management (52.02), Accounting (52.03), Business Economics (52.06), Financial Management (52.08), International Business (52.11), Business Information (52.12), Business Quantitative Methods (52.13) \& Marketing (52.14).

NOTE: Cost determinant is included in equation if coefficient is significant at the 10 percent level.

SOURCE: University of Delaware, The Delaware Study of Instructional Costs and Productivity, 1998-2001. 
Table D-18. Summary of determinants of direct instructional cost per student credit hour, by discipline: 1998 Delaware Study

[Dependent variable $=\log _{10}$ (Direct instructional cost per student credit hour $)$ ]

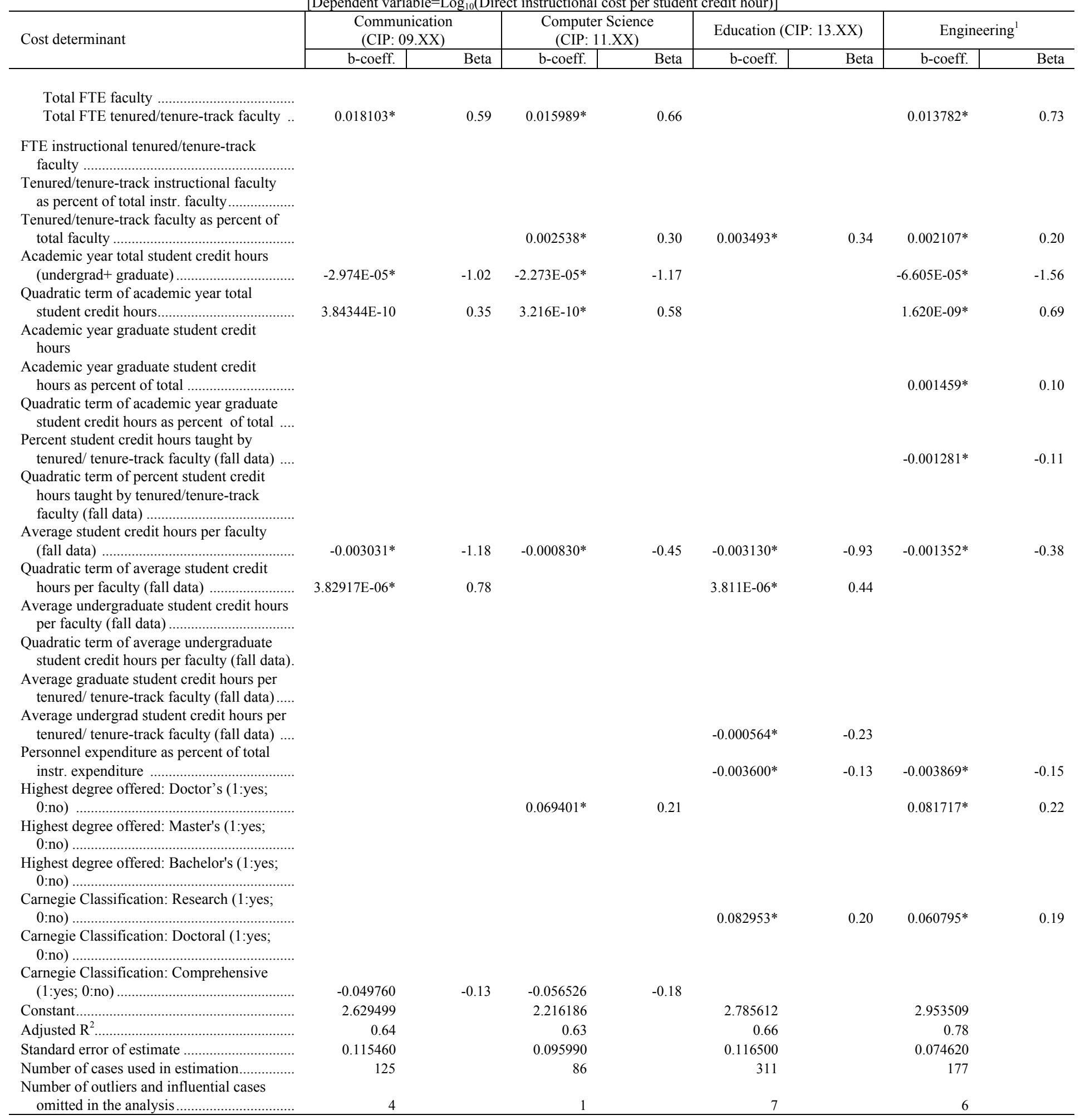

See notes at end of table. 
Table D-18. Summary of determinants of direct instructional cost per student credit hour, by discipline: 1998 Delaware Study-Continued

[Dependent variable $=\log _{10}$ (Direct instructional cost per student credit hour)]

\begin{tabular}{|c|c|c|c|c|c|c|c|c|}
\hline \multirow{2}{*}{ Cost determinant } & \multicolumn{2}{|c|}{ Foreign Languages (CIP:16.XX) } & \multicolumn{2}{|c|}{ English (CIP: 23.XX) } & \multicolumn{2}{|c|}{ Biology (CIP: 26.XX) } & \multicolumn{2}{|c|}{ Mathematics (CIP: 27.XX) } \\
\hline & b-coeff. & Beta & b-coeff. & Beta & b-coeff. & Beta & b-coeff. & Beta \\
\hline \multicolumn{9}{|l|}{ Total FTE faculty } \\
\hline \multicolumn{9}{|l|}{$\begin{array}{l}\text { FTE instructional tenured/tenure-track } \\
\text { faculty }\end{array}$} \\
\hline \multicolumn{9}{|l|}{$\begin{array}{l}\text { Tenured/tenure-track instructional faculty } \\
\text { as percent of total instr. faculty................... }\end{array}$} \\
\hline $\begin{array}{l}\text { Tenured/tenure-track faculty as percent of } \\
\text { total faculty }\end{array}$ & \multirow[t]{2}{*}{$0.001976^{*}$} & 0.24 & 0.001016 & 0.12 & $0.005045^{*}$ & 0.43 & & \\
\hline $\begin{array}{l}\text { Academic year total student credit hours } \\
\text { (undergrad+ graduate) }\end{array}$ & & -0.59 & $-1.732 \mathrm{E}-05^{*}$ & -1.67 & & & $-1.928 \mathrm{E}-05^{*}$ & -1.76 \\
\hline $\begin{array}{l}\text { Quadratic term of academic year total } \\
\text { student credit hours........................................ }\end{array}$ & & & $1.368 \mathrm{E}-10^{*}$ & 0.66 & & & $1.438 \mathrm{E}-10^{*}$ & 0.72 \\
\hline $\begin{array}{l}\text { Academic year graduate student credit } \\
\text { hours }\end{array}$ & & & & & & & & \\
\hline $\begin{array}{l}\text { Academic year graduate student credit } \\
\text { hours as percent of total }\end{array}$ & & & & & & & & \\
\hline $\begin{array}{l}\text { Quadratic term of academic year graduate } \\
\text { student credit hours as percent of total .... }\end{array}$ & & & & & & & & \\
\hline $\begin{array}{l}\text { Percent student credit hours taught by } \\
\text { tenured/ tenure-track faculty (fall data) .... }\end{array}$ & & & & & & & $0.004206^{*}$ & 0.53 \\
\hline $\begin{array}{l}\text { Quadratic term of percent student credit } \\
\text { hours taught by tenured/tenure-track } \\
\text { faculty (fall data) }\end{array}$ & & & & & & & $-0.000042 *$ & -0.60 \\
\hline $\begin{array}{l}\text { Average student credit hours per faculty } \\
\text { (fall data) }\end{array}$ & $-0.001108^{*}$ & -0.42 & $-0.000625^{*}$ & -0.26 & $-0.002915^{*}$ & -1.12 & $-0.000437 *$ & -0.22 \\
\hline $\begin{array}{l}\text { Quadratic term of average student credit } \\
\text { hours per faculty (fall data) ................................. }\end{array}$ & & & & & $2.375 \mathrm{E}-06^{*}$ & 0.48 & & \\
\hline $\begin{array}{l}\text { Average undergraduate student credit } \\
\text { hours per faculty (fall data) ............................ }\end{array}$ & & & & & & & & \\
\hline $\begin{array}{l}\text { Quadratic term of average undergraduate } \\
\text { student credit hours per faculty (fall } \\
\text { data) }\end{array}$ & & & & & & & & \\
\hline $\begin{array}{l}\text { Average graduate student credit hours per } \\
\text { tenured/ tenure-track faculty (fall data)..... }\end{array}$ & & & & & & & & \\
\hline $\begin{array}{l}\text { Average undergrad student credit hours per } \\
\text { tenured/ tenure-track faculty (fall data) .... }\end{array}$ & -0.000313 & -0.13 & $-0.000406^{*}$ & -0.22 & & & & \\
\hline $\begin{array}{l}\text { Personnel expenditure as percent of total } \\
\text { instr. expenditure }\end{array}$ & & & & & $-0.005052^{*}$ & -0.17 & & \\
\hline $\begin{array}{l}\text { Highest degree offered: Doctor's (1:yes; } \\
\text { 0:no) }\end{array}$ & $0.078670^{*}$ & 0.18 & $0.053231^{*}$ & 0.17 & $0.128692 *$ & 0.27 & $0.095089 *$ & 0.30 \\
\hline $\begin{array}{l}\text { Highest degree offered: Master's (1:yes; } \\
\text { 0:no) } \\
\text { Highest degree offered: Bachelor's (1:yes; } \\
\text { 0:no) }\end{array}$ & & & & & & & & \\
\hline $\begin{array}{l}\text { Carnegie Classification: Research (1:yes; } \\
0: \text { no) }\end{array}$ & & & & & & & & \\
\hline $\begin{array}{l}\text { Carnegie Classification: Doctoral (1:yes; } \\
0: \text { no) }\end{array}$ & & & & & & & & \\
\hline $\begin{array}{l}\text { Carnegie Classification: Comprehensive } \\
\quad(1: \text { yes; } 0: n o)\end{array}$ & -0.036076 & -0.10 & & & & & & \\
\hline Constant & 2.315728 & & 2.242552 & & 2.723573 & & 2.099311 & \\
\hline Adjusted $\mathrm{R}^{2} \ldots \ldots$ & 0.66 & & 0.64 & & 0.73 & & 0.62 & \\
\hline Standard error of estimate .................................... & 0.099790 & & 0.085900 & & 0.122070 & & 0.098210 & \\
\hline Number of cases used in estimation................... & 158 & & 149 & & 177 & & 134 & \\
\hline $\begin{array}{l}\text { Number of outliers and influential cases } \\
\text { omitted in the analysis................................... }\end{array}$ & 2 & & 3 & & 7 & & 2 & \\
\hline
\end{tabular}

See notes at end of table. 
Table D-18. Summary of determinants of direct instructional cost per student credit hour, by discipline: 1998 Delaware Study-Continued

[Dependent variable $=\log _{10}$ (Direct instructional cost per student credit hour)]

\begin{tabular}{|c|c|c|c|c|c|c|c|c|}
\hline \multirow{2}{*}{ Cost determinant } & \multicolumn{2}{|c|}{ Philosophy (CIP: 38.XX) } & \multicolumn{2}{|c|}{ Chemistry (CIP: 40.05) } & \multicolumn{2}{|c|}{ Geology (CIP: 40.06) } & \multicolumn{2}{|c|}{ Physics (CIP: 40.08) } \\
\hline & b-coeff. & Beta & b-coeff. & Beta & b-coeff. & Beta & b-coeff. & Beta \\
\hline \multicolumn{9}{|l|}{ 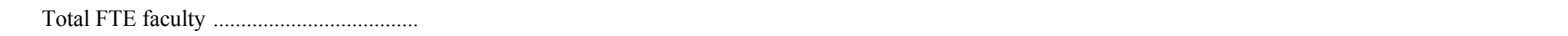 } \\
\hline \multicolumn{9}{|l|}{ 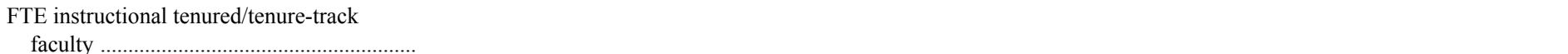 } \\
\hline \multicolumn{9}{|l|}{$\begin{array}{l}\text { Tenured/tenure-track instructional faculty } \\
\text { as percent of total instr. faculty .................... }\end{array}$} \\
\hline $\begin{array}{l}\text { Tenured/tenure-track faculty as percent of } \\
\text { total faculty }\end{array}$ & $0.001288^{*}$ & 0.15 & $0.002659^{*}$ & 0.31 & & & $0.003543 *$ & 0.35 \\
\hline $\begin{array}{l}\text { Academic year total student credit hours } \\
\quad \text { (undergrad }+ \text { graduate })\end{array}$ & $-2.957 \mathrm{E}-05^{*}$ & -0.74 & $-3.278 \mathrm{E}-05^{*}$ & -1.55 & $-0.000042 *$ & -0.69 & $-2.632 \mathrm{E}-05^{*}$ & -0.91 \\
\hline 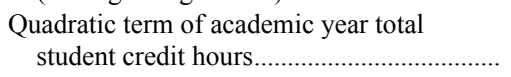 & & & $5.219 \mathrm{E}-10^{*}$ & 0.69 & & & & \\
\hline $\begin{array}{l}\text { Academic year graduate student credit } \\
\text { hours }\end{array}$ & & & & & & & & \\
\hline $\begin{array}{l}\text { Academic year graduate student credit } \\
\text { hours as percent of total }\end{array}$ & & & & & $0.023113^{*}$ & 0.44 & & \\
\hline $\begin{array}{l}\text { Quadratic term of academic year graduate } \\
\text { student credit hours as percent of total .... }\end{array}$ & & & & & $-0.001486^{*}$ & -0.35 & & \\
\hline $\begin{array}{l}\text { Percent student credit hours taught by } \\
\text { tenured/ tenure-track faculty (fall data) .... } \\
\text { Quadratic term of percent student credit } \\
\text { hours taught by tenured/tenure-track } \\
\text { faculty (fall data) }\end{array}$ & & & $-0.001373^{*}$ & -0.16 & & & $-0.001381 *$ & -0.18 \\
\hline $\begin{array}{l}\text { Average student credit hours per faculty } \\
\text { (fall data) }\end{array}$ & $-0.000583 *$ & -0.29 & $-0.002654 *$ & -1.22 & $-0.001332 *$ & -0.52 & $-0.002633 *$ & -1.18 \\
\hline $\begin{array}{l}\text { Quadratic term of average student credit } \\
\text { hours per faculty (fall data) }\end{array}$ & & & $0.000004 *$ & 0.84 & & & $0.000003 *$ & 0.77 \\
\hline 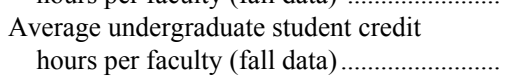 & & & & & & & & \\
\hline $\begin{array}{l}\text { Quadratic term of average undergraduate } \\
\text { student credit hours per faculty (fall } \\
\text { data). }\end{array}$ & & & & & & & & \\
\hline $\begin{array}{l}\text { Average graduate student credit hours per } \\
\text { tenured/ tenure-track faculty (fall data)...... }\end{array}$ & & & & & & & & \\
\hline $\begin{array}{l}\text { Average undergrad student credit hours per } \\
\text { tenured/ tenure-track faculty (fall data) .... }\end{array}$ & & & & & & & & \\
\hline $\begin{array}{l}\text { Personnel expenditure as percent of total } \\
\text { instr. expenditure }\end{array}$ & & & & & & & & \\
\hline Highest degree offered: Doctor's (1:yes; & & & & & & & & \\
\hline $\begin{array}{l}\text { 0:no) } \\
\text { Highest degree offered: Master's (1:yes; }\end{array}$ & $0.128665^{*}$ & 0.33 & $0.137640 *$ & 0.44 & & & $0.075447^{*}$ & 0.21 \\
\hline $0:$ no) & $0.057013^{*}$ & 0.13 & & & & & $0.053627 *$ & 0.13 \\
\hline $\begin{array}{l}\text { Highest degree offered: Bachelor's (1:yes; } \\
0: \text { no) }\end{array}$ & & & & & & & & \\
\hline $\begin{array}{l}\text { Carnegie Classification: Research (1:yes; } \\
0: \text { no) }\end{array}$ & & & & & & & $0.097769^{*}$ & 0.27 \\
\hline 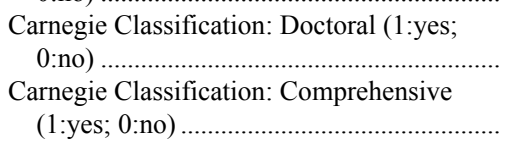 & $0.057464^{*}$ & 0.14 & & & & & & \\
\hline 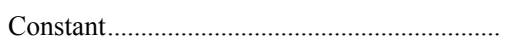 & 2.097833 & & 2.498669 & & 2.410171 & & 2.433530 & \\
\hline Adjusted $R^{2} \ldots \ldots \ldots$ & 0.54 & & 0.61 & & 0.75 & & 0.77 & \\
\hline 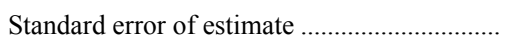 & 0.107570 & & 0.098170 & & 0.107550 & & 0.082670 & \\
\hline $\begin{array}{l}\text { Number of cases used in estimation................ } \\
\text { Number of outliers and influential cases }\end{array}$ & 138 & & 101 & & 68 & & 91 & \\
\hline 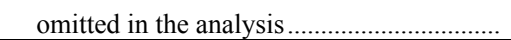 & 1 & & 2 & & 3 & & 9 & \\
\hline
\end{tabular}

See notes at end of table. 
Table D-18. Summary of determinants of direct instructional cost per student credit hour, by discipline: 1998 Delaware Study, -Continued

[Dependent variable $=\log _{10}($ Direct instructional cost per student credit hour $\left.)\right]$

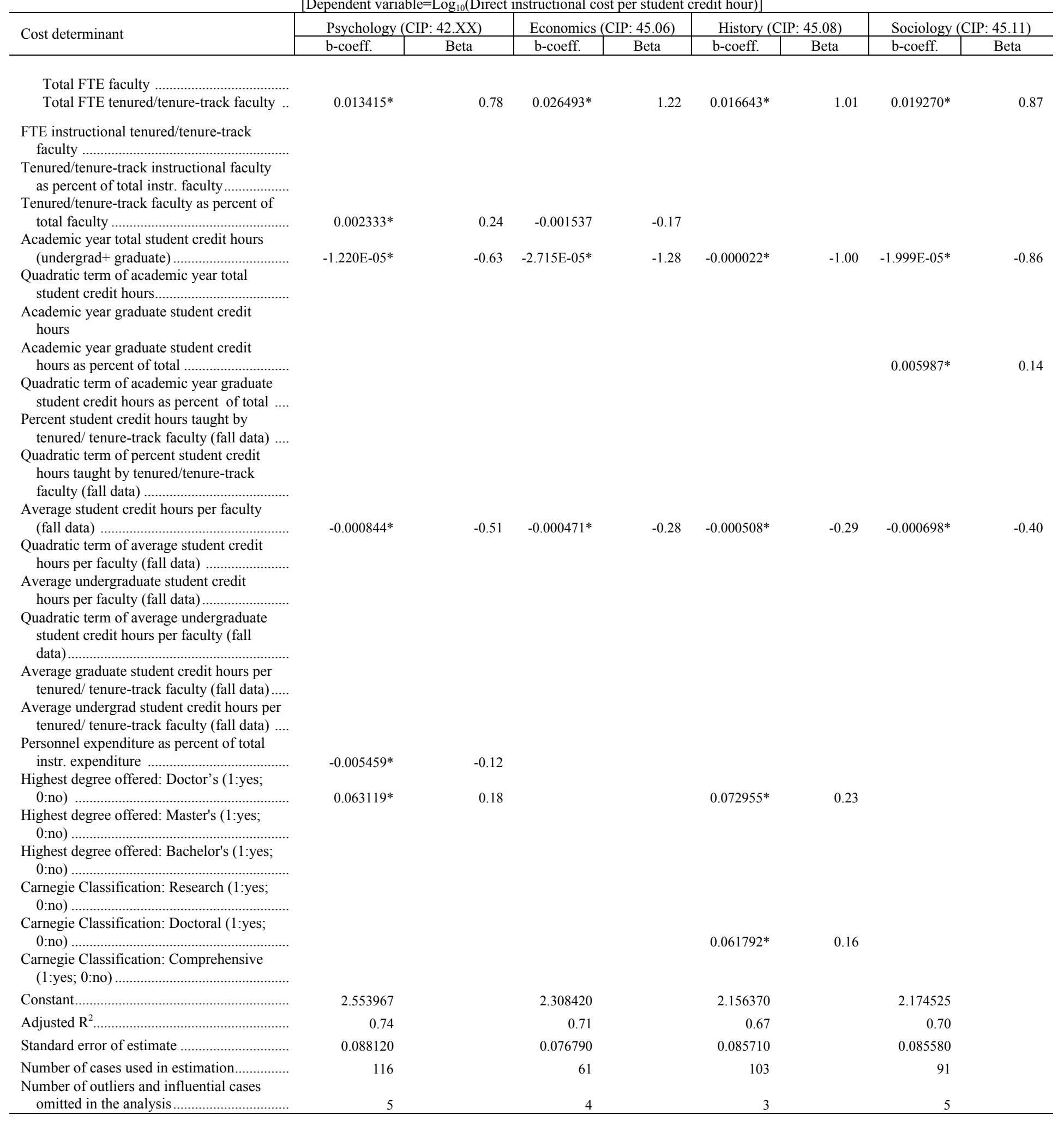

See notes at end of table. 
Table D-18. Summary of determinants of direct instructional cost per student credit hour, by discipline: 1998 Delaware Study_Continued

[Dependent variable $=\log _{10}$ (Direct instructional cost per student credit hour)]

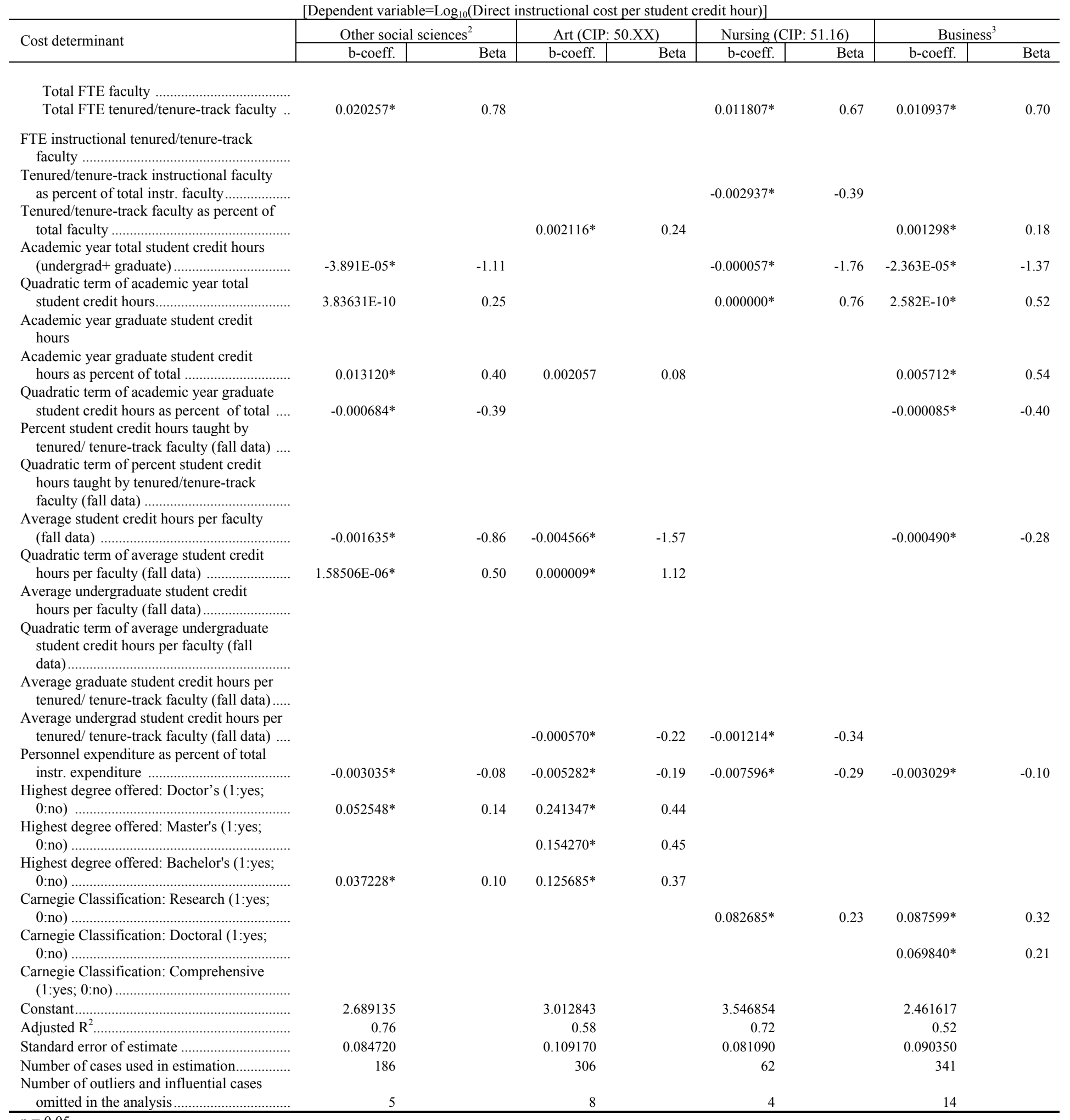

$\mathrm{p}=0.05$

${ }^{1}$ Includes Chemical Engineering (14.07), Civil Engineering ( 14.08), Electrical Engineering (14.10), and Mechanical Engineering (14.19).

${ }^{2}$ Includes Political Science (45.10), Anthropology (45.02), and Geography (45.07).

${ }^{3}$ Includes Business General (52.01), Business Administration and Management (52.02), Accounting (52.03), Business Economics (52.06), Financial Management (52.08), International Business (52.11), Business Information (52.12), Business Quantitative Methods (52.13) \& Marketing (52.14).

NOTE: Cost determinant is included in equation if coefficient is significant at the 10 percent level.

SOURCE: University of Delaware, The Delaware Study of Instructional Costs and Productivity, 1998-2001. 
Appendix E

\section{Technical Notes}


E-2 
General Approach to Data Analysis

Data analysis in this study focuses on 25 disciplines that are typically found at 4-year institutions, regardless of complexity or institutional mission. The examination focused on four-digit CIP wherever possible, or two-digit CIP as appropriate. Those disciplines and their associated CIP codes follow.

Table E-1. Classification by instructional program (CIP) codes

\begin{tabular}{ll}
\hline CIP & Discipline \\
09.xx & Communication \\
11.xx & Computer/Info Science \\
13.xx & Education \\
14.07 & Chemical Engineering \\
14.08 & Civil Engineering \\
14.10 & Electrical Engineering \\
14.19 & Mechanical Engineering \\
$16 . x \mathrm{x}$ & Foreign Languages \\
$23 . \mathrm{xx}$ & English \\
$26 . \mathrm{xx}$ & Biological Sciences \\
$27 . \mathrm{xx}$ & Mathematics \\
$38 . \mathrm{xx}$ & Philosophy \\
40.05 & Chemistry \\
40.06 & Geology \\
40.08 & Physics \\
$42 . \mathrm{xx}$ & Psychology \\
45.02 & Anthropology \\
45.06 & Economics \\
45.07 & Geography \\
45.08 & History \\
45.10 & Political Science \\
45.11 & Sociology \\
$50 . \mathrm{xx}$ & Visual/Performing Arts \\
51.16 & Nursing \\
$52 . \mathrm{xx}$ & Business \\
\hline &
\end{tabular}

The total number of analytical units for these 25 disciplines ranges from 2,700 in the 1999 data collection cycle to 4,240 in the 2001 cycle.

\section{Developing National Benchmarks}

In analyzing the Delaware Study data within each data set, national benchmarks are computed. The initial step in the computation is the inclusion of all institutional responses with each Carnegie class for a given variable. From those total responses, an initial mean value is calculated. The responses are then further analyzed to identify those cases that are beyond two standard deviations above or below the initial mean. These cases are then defined as outliers and are excluded from the subsequent calculation of the refined mean. This conservative approach to benchmark construction was taken to ensure that no single or set of idiosyncratic responses exert undue influence on the calculation of a mean value or benchmark. This process is known as Windsorization, and theoretically excludes 2.5 percent of the data points at the low and high end of the range. In effect, refined means are calculated from the middle 95 percent of the data points.

Each of the calculated variables described in the Glossary is analyzed to determine whether specific institutional characteristics at the academic discipline level impact upon teaching loads and expenditures. Those characteristics include:

- Carnegie institutional classification,

- highest degree offered within the discipline, and

- relative emphasis on undergraduate versus graduate instruction within discipline.

The Carnegie institutional classification, as an instructional workload/cost factor, is predicated on a series of assumptions. The expectation is that research universities teach less and cost more than doctoral universities, which in turn teach less and cost more than comprehensive and baccalaureate institutions. This will be examined for each 
discipline, and if and where the assumption is negated, the issue of sample dependency is examined.

Two other institutional characteristics lend themselves to analysis. The assumed impact of highest degree offered is straightforward, i.e., doctorate-granting disciplines will teach less and cost more than master's-granting disciplines, which in turn will teach less and cost more than baccalaureate-only disciplines. This is an important consideration in looking at the overall disciplinary mix at an institution. The higher the concentration of doctorate and master's degree programs, the higher would be the expected instructional costs.

It is also important to examine the relative emphasis on undergraduate versus graduate instruction. One might look at two chemical engineering departments, both offering the doctorate. One teaches only 20 percent of its total student credit hours at the graduate level, while the other teaches over half of its student credit hours at the graduate level. Consideration of this factor enables distinguishing of cost differentials that are not so directly captured by either Carnegie institutional classification or highest degree awarded in the discipline. The Delaware Study benchmarks assess undergraduate versus graduate program mix within a discipline by examining the distribution of degrees awarded at the undergraduate versus graduate levels.

\section{Variation in Cost}

National benchmark cost data derived from annual Delaware Study data collection cycles repeatedly and consistently show variations in cost by discipline. Direct instructional expense per student credit hour taught ranges from the low $\$ 100$ s for some disciplines in the social sciences to well over $\$ 400$ in disciplines in engineering and the physical sciences. It is important to understand the nature of these cost differentials.

At the very basic level, historical data from the Delaware Study indicate that costs vary among disciplines regardless of institutional mission. The data further show that within a given discipline, there is variation in cost among the pool of institutions participating in the Delaware Study in any year. This leads to the question as to where important cost differentials occur. Are variations in cost predominantly occurring among disciplines within institutions, or are they mostly due to categorical differences among the institutions themselves? These sources of variance are examined and described using hierarchical linear modeling.

The data gathered in the Delaware Study follow a classical hierarchical data structure. Variables such as cost of instruction and faculty workload are collected at the discipline level and may be grouped by institution. Part of the variance in cost can be attributed to disciplines within institution. However, cost may in turn be affected by the type of institution such as that based on Carnegie classification. Hierarchical linear modeling allows variance decomposition into within-institution and between-institution components.

In the two-level hierarchical data structure, disciplines are considered the level 1 units and institutions the level 2 units. The one-way analysis of variance, which is the simplest possible hierarchical model, is applied to cost where no explanatory variables are used in either discipline or institution. This provides the "baseline" measure of the variation in cost. In subsequent models, the effect of Carnegie classification and broad discipline grouping according to cost levels are disaggregated from the variance.

While no inferences on population cost estimates are possible, similarities or nonsimilarities of cost among the 25 disciplines under examination are analyzed and described. An in-depth test of difference in cost by discipline is applied to the data using analysis of variance (ANOVA). How costs vary by discipline in conjunction with institutional mission, highest degree awarded in the discipline, and the relative emphasis on undergraduate versus graduate instruction in the discipline is examined. It is important to replicate the analysis over multiple data cycles for validation of the findings; hence data from the 1998, 2000, and 2001 Delaware Study data collections are analyzed and described. 


\section{Cost Factors}

Prior analysis of Delaware Study data (Middaugh and Graham 1998) suggests that there is substantial variation in the unit cost of instruction between and among individual disciplines and groupings of disciplines. Based upon that analysis, it can also be postulated that determinants of instructional cost may also vary by discipline. Consequently, data from the 1998, 2000, and 2001 Delaware Study data collection cycles are systematically examined to determine factors that directly impact instructional expenditures within each discrete data collection cycle. The data are further examined to determine if there is a pattern in cost determinants over time, i.e., across multiple data collection cycles. Specifically, the following variables, each of which is a Delaware Study benchmark, are examined through multiple regression analysis with respect to their significance in predicting the direct cost of instruction.

- Department size, as measured by total FTE faculty and by FTE instructional faculty. (The latter is the former, net of any contractual buyouts for activity other than instruction.)

- Proportion of faculty who are tenured or who are on tenure track. Tenured and tenure-track faculty are, on average, better compensated than other categories of faculty. Moreover, tenure makes this group largely a fixed cost. Consequently, the larger this proportion, the higher the unit cost of instruction.

- Total student credit hours taught in an academic year. Typically, the unit cost of an item-in this instance, a student credit hour-would be expected to decrease as the number of units being produced increases.

- Graduate student credit hours as a proportion of total student credit hours taught. Graduate level instruction is more expensive than undergraduate instruction. Classes are typically smaller; interactions with faculty, particularly tenured and tenure-track faculty, are more frequent and individualized, etc. It would therefore be reasonable to expect that the more graduate oriented a department, the more expensive the instruction.

- Faculty teaching load during an academic year as measured by the number of student credit hours taught per FTE faculty, and/or the number of FTE students taught (a derivative of student credit hours that is sensitive to level of instruction) per FTE faculty. It is assumed that the heavier the teaching load per FTE faculty, the lower the cost of instruction.

- Personnel expenditures as a percentage of total instructional expenditures. For some disciplines, most notably equipment-intensive disciplines such as the natural and physical sciences and engineering, a large added cost of instruction is due to nonpersonnel expenses, i.e., expenditures not associated with employee salaries and benefits. It is assumed that the unit cost of instruction will be lower in disciplines where most of the instructional expense is personnel related.

- Highest degree offered. It is hypothesized that the expected cost of instruction in a department or discipline that offers only the bachelor's degree will be lower than those offering graduate degrees as well.

- Institutional control, i.e., publicly versus privately supported institutions. There are those who argue that private institutions typically feature smaller class sizes, more individual attention to students, etc. If this is in fact the case, it should impact direct instructional expenditures at those institutions. The feasibility of using this variable was examined in 1998, and again in the present study, and in both instances was eliminated due to the comparatively low participation rate among private institutions, which resulted in too few data points at the academic discipline level to yield meaningful and valid analysis.

- Institutional mission, as inferred from the 1995 Carnegie institutional taxonomy. It is hypothesized that baccalaureate and comprehensive institutions intrinsically teach more in terms of student credit hour volume 
and faculty teaching loads than doctoral universities, which in turn teach more than research universities. If true, this impacts direct instructional expense.

Highest degree offered and institutional mission, as previously defined, have been translated into indicator variables for multiple regression analysis. These variables take on a value of either zero or one, where a value of one signifies a class membership.

Comprehensive cost models were sought for each discipline, using multiple regression analysis. In addition to analyzing and describing the linear relationship of cost and the continuous variables-such as academic year student credit hours taught, academic year graduate student credit hours as a proportion of total student credit hours taught by tenured and tenure-track faculty, etc. - the quadratic term for each of these variables was also tested in the model to account for possible nonlinear relationships with cost. Likewise, the interaction terms between the dummy variables for Carnegie classification and highest degree offered and the same continuous variables were analyzed and described.

In order to conform to the assumptions underlying regression analysis, data points wherein the unit cost is beyond two standard deviations from the mean were eliminated at the onset of analysis. These cases were omitted from analysis, as they are idiosyncratic and potentially exert undue impact on developing equations. Outliers and influential cases were identified by examining the residuals obtained from initial regression analyses and were subsequently omitted. The majority of the outliers have unit cost per student credit hours that are grossly high, i.e., standardized residual of three or higher. Influential cases were identified as those with relatively large values for Cook's Distance. The study of the residuals from the initial analysis repeatedly showed that the assumption of constant variance or homoscedasticity is violated. To correct for this, the dependent variable, cost per student credit hour, was transformed to logarithm.
Inclusion of the independent variables in the equation is a function of how strongly the variables independently or jointly affect instructional cost. The predictor variables that are included in these equations have regression coefficients that are significant at the 10 percent level. In a few instances, however, some variables were retained in order to have more meaningful and complete cost models. In part, inclusion of the variables depends upon the magnitude of the colinearity among these variables. Care was taken to ensure that multicolinearity was minimized.

The analytical strategy employed is to identify major cost drivers within each of the 25 academic disciplines under examination, to then determine whether these cost drivers vary among disciplines, and ultimately to examine if the identified cost drivers are consistent over multiple data collection cycles. In examining the 25 disciplines within any given data collection cycle, it is imperative to ensure that sufficient data points are present to allow for reliable use of multiple regression methodology. The question of insufficient data points occurred in disciplines at the four-digit CIP grouping. In certain instances, it was necessary to collapse some disciplines at the four-digit CIP into larger naturally affiliated groupings in order to achieve sufficient data points as well as to increase the predictive power of the model. Such is the case for the four engineering disciplines where combining them yielded a more highly predictive cost model. Similarly, combining political science with anthropology and geography produced more reliable cost models than when each is taken individually.

The analytical process for each of the disciplines under examination was kept as consistent as possible. Specifically, the following protocols were adopted for all equations:

- Cost per student credit hour taught is the dependent variable. Cost is transformed to logarithm in the analysis.

- Data points wherein unit cost is beyond two standard deviations from the mean are omitted at the onset of the analysis. 
- Outliers are defined as those cases in which the absolute value of the standardized residual is three or higher, and are subsequently omitted.

- Influential cases are identified as those with relatively high values of Cook's Distance and/or Mahalanobis Distance statistics. These cases are omitted in the final analysis.

- The quadratic term of all continuous variables are tested for inclusion in the model to account for possible nonlinear relationships with cost.
- Interaction terms between selected continuous variables and categorical variables (highest degree offered and Carnegie institutional classification) were tested for inclusion in the model.

- Variables are retained in the equation only if their regression coefficients are statistically significant at the 10 percent level.

For disciplines that are a two-digit CIP aggregation, data points belonging to a four-digit subdiscipline with two or fewer institutions reporting were eliminated from the aggregation. 
E-8 
U.S. Department of Education

U.S. POSTAGE PAID

ED Pubs

8242-B Sandy Court

Jessup, MD 20794-1398

Official Business

U.S. DEPARTMENT

OF EDUCATION

PERMIT NO. G-17

Penalty for Private Use, $\$ 300$

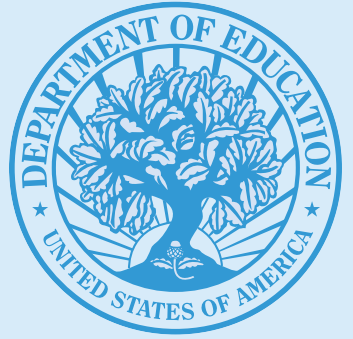

